\title{
ASSESSMENT OF EARNINGS CONSERVATISM IN MALAYSIAN FINANCIAL REPORTING
}

\author{
By \\ Khairul Anuar Bin Kamarudin
}

A thesis

submitted to the Victoria University of Wellington in fulfilment of the requirements for the degree of Doctor of Philosophy in Accounting

Victoria University of Wellington 2011 
I dedicate this dissertation to my children,

Najmi, Ainul, and Imran, who always give me so much joy and love. 


\section{Research Supervisors}

Professor Tony van Zijl

School of Accounting and Commercial Law,

Victoria University of Wellington,

Wellington, New Zealand.

Professor Keitha Dunstan

School of Business, Bond University,

Gold Coast, Australia. 


\section{Declaration on Sources}

I hereby confirm that the work presented in this thesis is my own and original work that has been carried out through the School of Accounting and Commercial Law, Victoria University of Wellington, during my candidature as a PhD student. I declare that the material of this thesis has not been submitted either in whole or in part for the award of any other degree or diploma at this or any other university. To the best of my knowledge and belief, it contains no material previously published or written by other persons or institutions except where due reference has been made.

Khairul Anuar Bin Kamarudin 


\section{Acknowledgments}

I wish to express my deepest gratitude and appreciation to Prof. Tony van Zijl and Prof. Keitha Dunstan, my supervisors, for their invaluable guidance and support during my years in the doctoral programme, especially throughout the development and completion of this thesis. I would also like to thank Prof. Stephen Taylor, Prof. Peter Clarkson, and Prof. Michael Bradbury for their helpful comments and feedback. This thesis has also benefited from the comments of the faculty and participants of the SACL-VUW Doctoral Consortium, the AFAANZ Conference and Doctoral Symposium, the Quantitative Accounting Research Symposium/Auckland University, and the CAAA 2010 Conference.

Special thanks are due to Prof. Ian Eggleton, the Head of School, and to all SACL staff for their support. I also appreciate the friendship, interest, and support of my doctoral colleagues. I also acknowledge the financial grants received from UiTM-MOHE, Victoria University of Wellington, and the New Zealand Institute of Chartered Accountants.

I would like to express my deepest appreciation to my wife, Wan Adibah, for her unwavering support through this entire process. This thesis would not have been possible without her support and patience. To my parents, Kamarudin and Che Nah, and family, I am grateful for the support offered and prayers made to ensure success in my study and in life. Finally, I must acknowledge several friends who have continually provided assistance and support especially to my children, which allowed me to focus a significant amount of my time on research. I acknowledge Niklin, Dar, Dasuki, and Zuryati. 


\begin{abstract}
This study examines four influences on earnings conservatism of financial reporting in Malaysia. The study employs a sample of 3,126 firm-year observations of Malaysian listed companies over the period 2003 to 2008 and measures conservatism by the asymmetric timeliness of earnings measure due to Basu (1997). First, the study assesses the degree of earnings conservatism in reporting during the period following the institutional reforms which started after the 1997 Asian financial crisis. The results suggest that conservatism has increased with the reforms which contrasts with the findings of Ball et al. (2003) who find no evidence of earnings conservatism in Malaysia. Second, this study investigates the effect of the adoption of IFRS on the level of earnings conservatism. The results show no systematic difference in the level of earnings conservatism for the short period of one to two years before and after the adoption, suggesting that conservatism may not be specific to any particular set of accounting standards. Third, this study examines the effect of ownership structure on earnings conservatism. Reporting by family firms and widely-held firms exhibits earnings conservatism, but this is not the case for state-controlled firms. The analysis also shows no significant difference between the levels of earnings conservatism for family firms and widely-held firms. Additional tests show that family firms that are strategically controlled by a family, that is, where a member of the controlling family acts as CEO and chairman of the corporate board, report significantly higher earnings conservatism than other family firms. Finally, the study examines the link between corporate governance and earnings conservatism. Employing a comprehensive set of corporate governance variables, this study does not find any evidence to link corporate governance and earnings
\end{abstract}


conservatism. This result is contrary to the evidence from developed markets, such as the United States and the United Kingdom, where firms with good governance are more timely in recognising bad news. This raises the possibility that the different ownership structures in Malaysia make corporate governance reforms less important. However, this suggestion is subject to environmental and cultural issues that have not been addressed in this study. 


\section{Table of Contents}

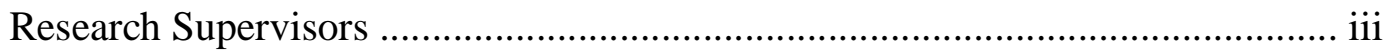

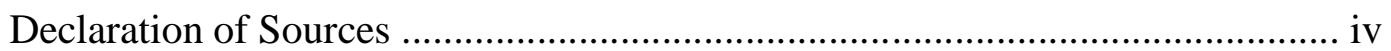

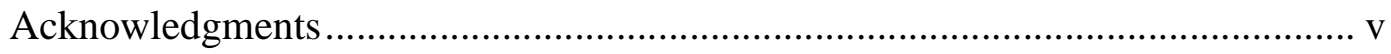

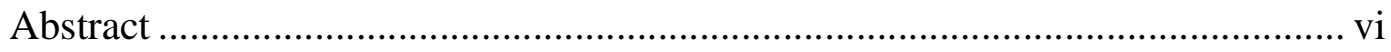

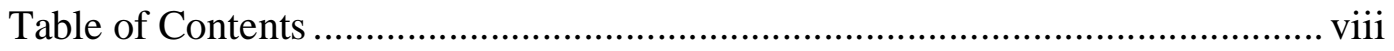

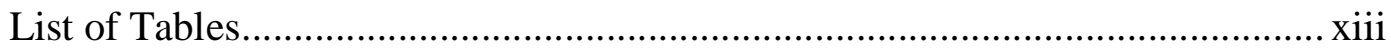

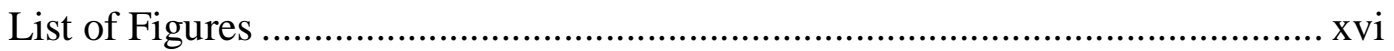

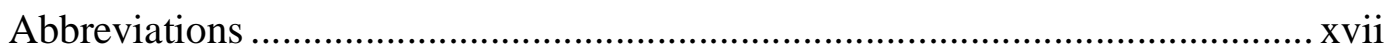

Chapter One: Introduction

1.1 Background and Objectives of the Thesis..................................................... 1

1.2 Significant Contributions of This Thesis ....................................................... 3

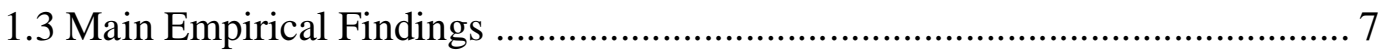

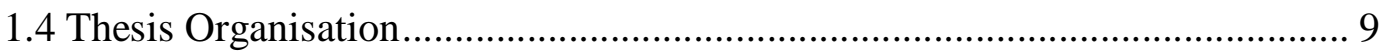

Chapter Two: Earnings Conservatism: A Review of Literature

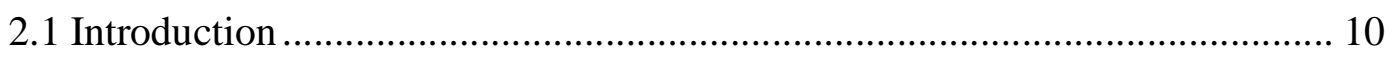

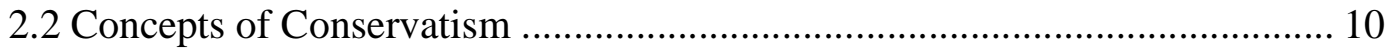

2.3 Theoretical Explanations for Conservatism ............................................... 12

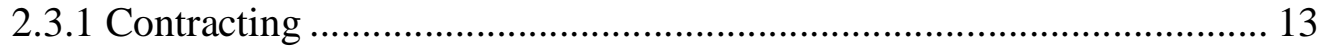

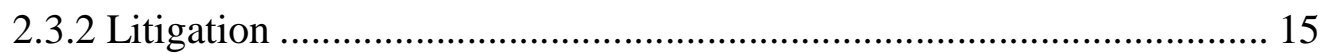

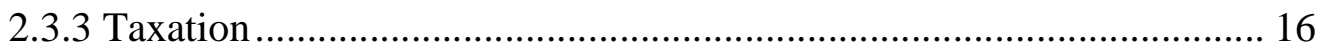

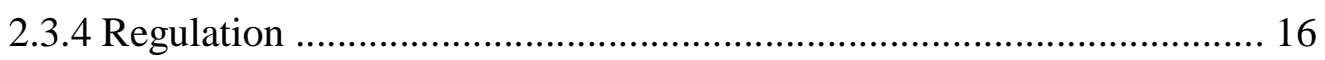

2.4 Development of Earnings Conservatism Measures ..................................... 17

2.4.1 The Asymmetric Timeliness of Earnings Model - Basu (1997)........... 18

2.4.2 The Time-Series Test of Loss Recognition - Basu (1997) .................. 20

2.4.3 Accruals-Based Test of Loss Recognition - Ball and

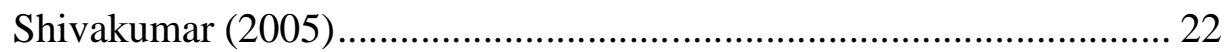

2.4.4 Firm-Year Measure - Francis, LaFond, Olsson, and Schipper

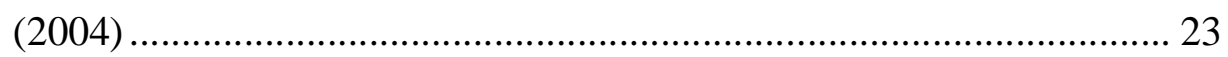

2.4.5 Firm-Year Measure - Khan and Watts (2009) .................................. 23 
2.5 Institutional Structure and Earnings Conservatism................................... 25

2.6 Firm-Specific Factors and Earnings Conservatism.................................... 29

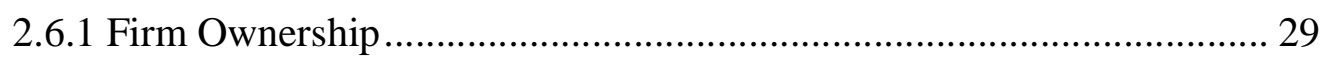

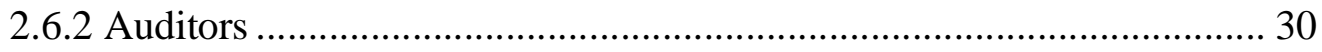

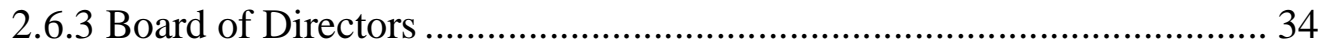

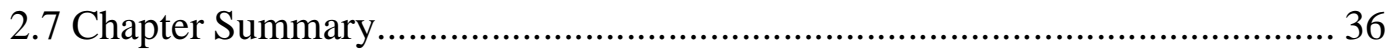

Chapter Three: Malaysian Institutional Background: Corporate Governance, Financial Reporting, and Ownership Structure

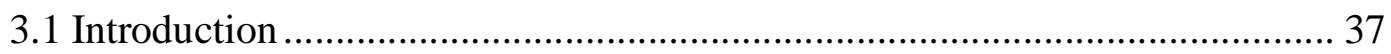

3.2 The 1997 Asian Economic Crisis and Reforms in Corporate Governance..... 37

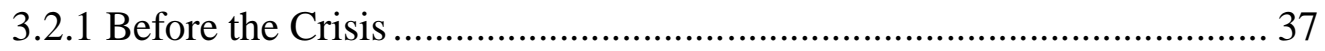

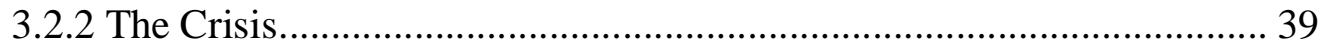

3.3 Financial Reporting Reforms and Adoption of IFRS ............................... 48

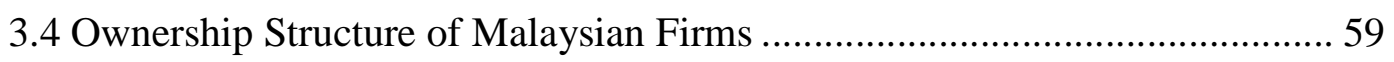

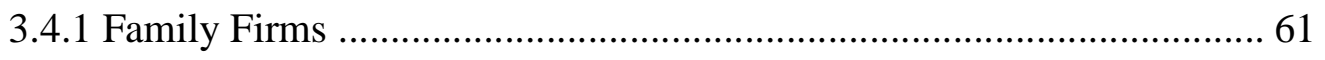

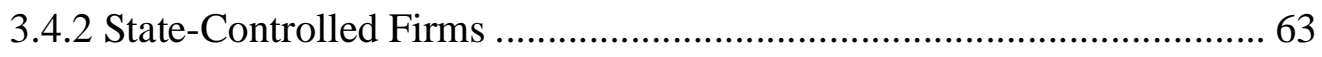

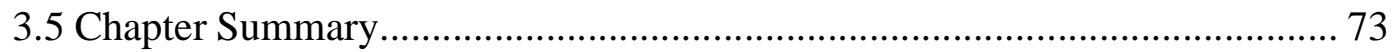

Chapter Four: Research Objectives and Hypotheses Development

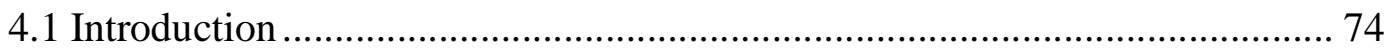

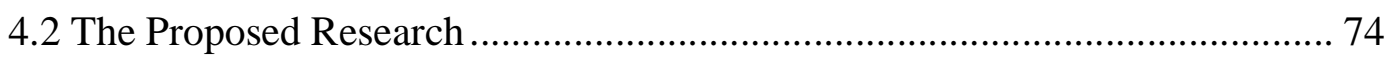

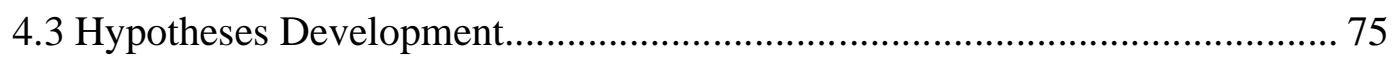

4.3.1 Earnings Conservatism Following Institutional Reforms ................... 76

4.3.2 IFRS Adoption and Earnings Conservatism..................................... 79

4.3.3 Ownership Structure and Earnings Conservatism .............................. 83

4.3.3.1 Family Firms and Earnings Conservatism ................................ 83

4.3.3.2 State-Controlled Firms and Earnings Conservatism.................. 87

4.3.4 Corporate Governance and Earnings Conservatism........................... 91

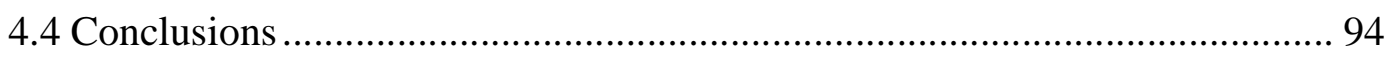

Chapter Five: Research Methodology

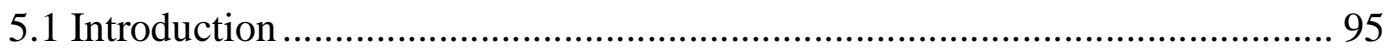


5.2 Sample Selection and Data Collection...................................................... 95

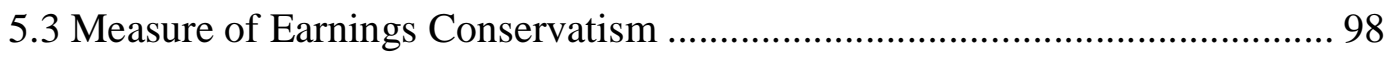

5.4 Classification For Pre- and Post-IFRS Adoption ...................................... 100

5.5 Measurement of Ownership Structure .................................................... 101

5.6 Measurement of Corporate Governance .................................................. 103

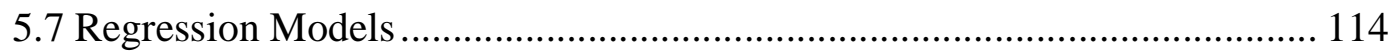

5.7.1 Earnings Conservatism in Malaysia .............................................. 114

5.7.2 IFRS Adoption and Earnings Conservatism.................................. 115

5.7.3 Ownership Structure and Earnings Conservatism ............................ 117

5.7.4 Corporate Governance and Earnings Conservatism.......................... 117

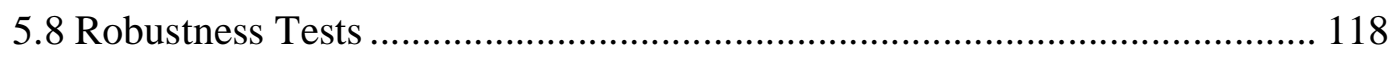

5.8.1 Alternative Measure for Earnings Conservatism .............................. 119

5.8.2 Fama and MacBeth (1973) Annual Regression................................ 120

5.8.3 Control for Firm-Specific Variables .............................................. 120

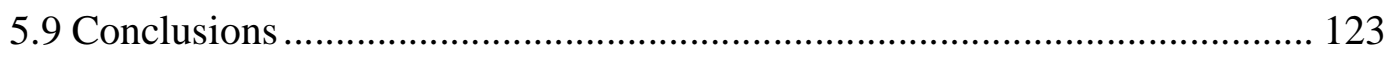

Chapter Six: Empirical Analysis

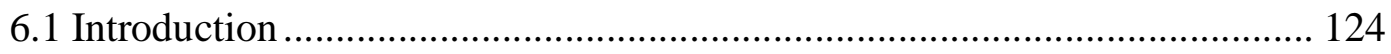

6.2 Descriptive Statistics and Correlation Analysis .......................................... 124

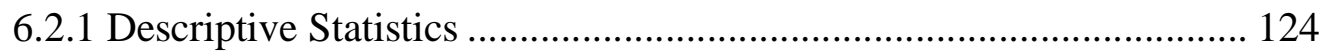

6.2.2 Correlation Analysis .................................................................. 128

6.2.3 Econometric Issues ..................................................................... 131

6.3 Earnings Conservatism Following the Reforms ..................................... 136

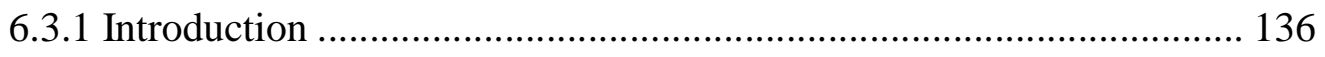

6.3.2 Main Analysis: Earnings Conservatism in Malaysia......................... 136

6.3.3 Sensitivity Analysis ....................................................................... 140

6.3.3.1 Fama and MacBeth (1973) Annual Regression ....................... 140

6.3.3.2 Industry and Year Effects ................................................... 141

6.3.3.3 Control for Firm-Specific Variables ........................................ 143

6.3.3.4 Restricted Sample - Firm Audited by Big Four Auditors ........ 146

6.3.3.5 Market-Adjusted Return ...................................................... 148

6.3.3.6 Inter-Announcement Period Stock Return ............................... 150

6.3.3.7 Reduced Sample: Stock Price Higher than MYR 1.00 ............ 152 
6.3.3.8 Time-series Test of Timeliness in Loss Recognition. 154

6.3.4 Discussion of the Results.

6.4 IFRS Adoption and Earnings Conservatism .......................................... 158

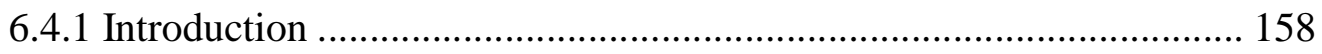

6.4.2 Main Analysis: The Effect of IFRS Adoption on Earnings Conservatism 158

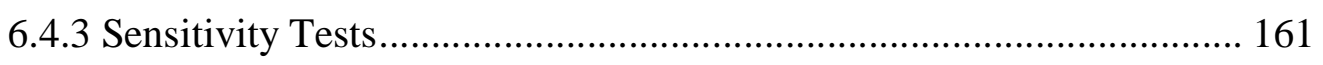

6.4.3.1 Control for Industry and Year Effects................................... 162

6.4.3.2 Sample of Firms with Financial Year Ended 31

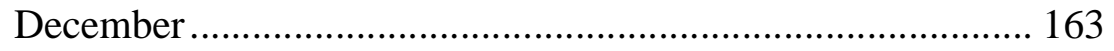

6.4.3.3 Firms with Big Four Auditors ............................................... 165

6.4.3.4 Auditors' Industry Specialization ........................................... 167

6.4.3.5 Time-Series Test of Timeliness in Loss Recognition .............. 169

6.4.4 Discussion of the Results............................................................. 171

6.5 Ownership Structure and Earnings Conservatism................................... 173

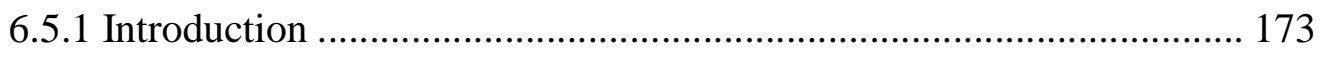

6.5.2 Main Analysis: Ownership Structure and Earnings

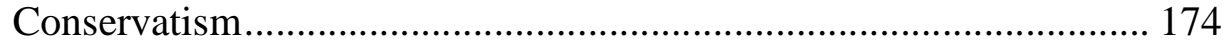

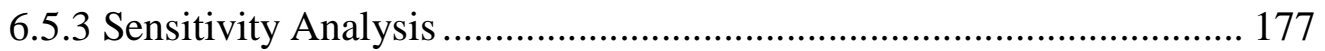

6.5.3.1 Fama and MacBeth (1973).................................................... 177

6.5.3.2 Industry and Year Effects .................................................. 179

6.5.3.3 Time-Series Test of Timeliness in Loss Recognition ............... 180

6.5.3.4 Alternative Measures for Family Firms ................................. 182

6.5.3.5 State-Controlled Firms: Federal and States' Firms.................. 185

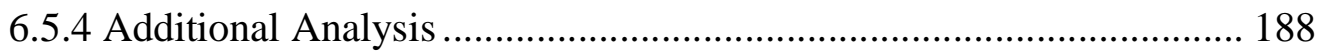

6.5.4.1 Difference in Earnings Conservatism between Family

Firms and Widely-Held Firms. ........................................... 189

6.5.4.2 Strategic Control of Controlling Family and Earnings

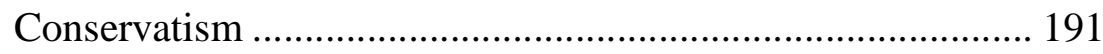

6.5.5 Discussion of the Results.................................................................... 196

6.6 Corporate Governance and Earnings Conservatism ................................... 198

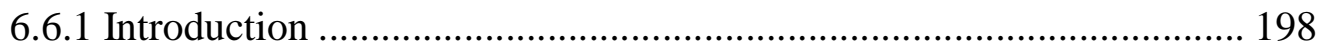


6.6.2 Corporate Governance Mechanism and Earnings Conservatism 199

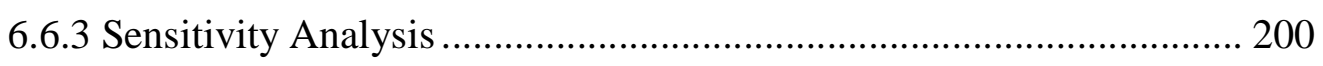

6.6.3.1 Alternative Measure for CGINDEX ..................................... 200

6.6.3.2 Individual Measures for Corporate Governance ..................... 202

6.6.3.3 Time-Series Test of Timeliness in Loss Recognition .............. 205

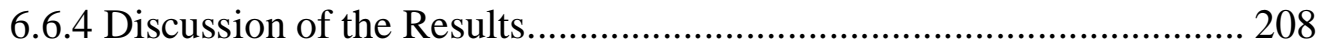

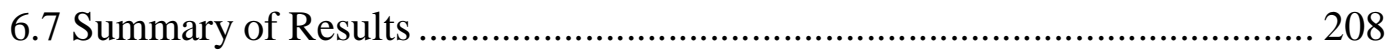

Chapter Seven: Conclusions

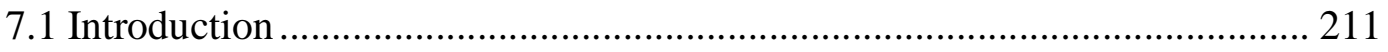

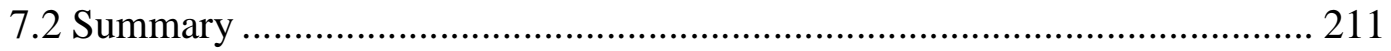

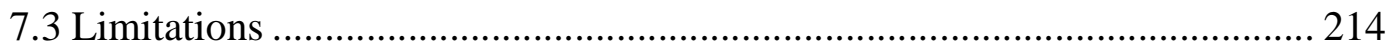

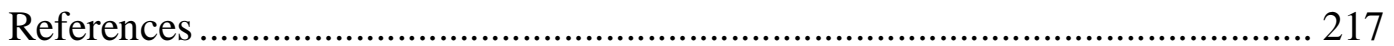

Appendix 1 Summary of studies on earnings conservatism ............................. 234

Appendix 2 Main differences between FRS and MASB standards ................... 251 


\section{List of Tables}

Table 3.1 Corporate governance initiatives and reforms (1997-2002) ............... 42

Table 3.2 List of MASB Standards as at 31 December 2003 ........................... 52

Table 3.3 Change of name of MASB standards on January 1, 2005 .................. 56

Table 3.4 IFRS adoption in Malaysia as at 31 December 2008 ........................ 58

Table 3.5 Ownership of YTL Corporation and its holding company ................. 62

Table 3.6 Share Issue Privatization in Malaysia (1983-1999) ........................... 65

Table 3.7 Government-Linked Companies in Bursa Malaysia .......................... 66

Table 3.8 Substantial shareholders of Malayan Banking Berhad ...................... 70

Table 3.9 Summary of government-linked companies delisted from Bursa

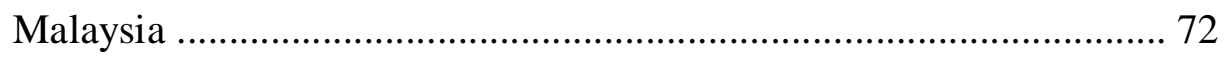

Table 4.1 Directors' profiles for Sime Darby Berhad ..................................... 90

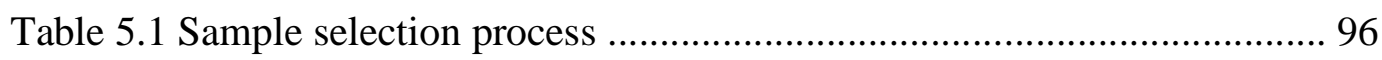

Table 5.2 List of variables, sources and definitions ........................................ 97

Table 5.3 IFRS adoption and period classification ...................................... 100

Table 6.1 Sample characteristics ........................................................... 125

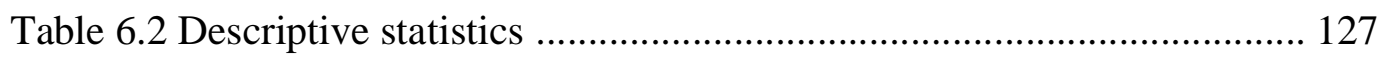

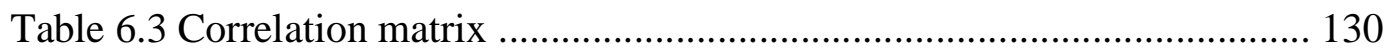

Table 6.4 Analysis for unusual observation and normality ............................ 132

Table 6.5 Diagnostic tests for Heteroscedasticity assumption ........................ 135

Table 6.6 Asymmetric timeliness of earnings ............................................ 137

Table 6.7 Asymmetric timeliness of earnings: Fama and MacBeth (1973) annual

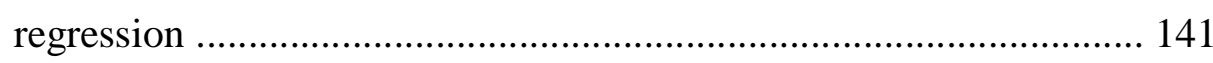

Table 6.8 Asymmetric timeliness of earnings: Controlling for industry and year

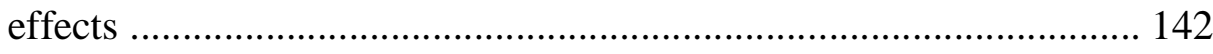


Table 6.9 Asymmetric timeliness of earnings: Controlling for firm-specific variables

Table 6.10 Asymmetric timeliness of earnings: Firms audited by Big Four auditors

Table 6.11 Asymmetric timeliness of earnings: Alternative measure for news (market adjusted return)

Table 6.12 Asymmetric timeliness of earnings: Alternative measure for news (inter-announcement date return)

Table 6.13 Asymmetric timeliness of earnings: Sample with stock price greater than MYR 1.00

Table 6.14 Time-series test of timeliness in loss recognition: Various specifications 156

Table 6.15 IFRS adoption and earnings conservatism 160

Table 6.16 IFRS adoption and earnings conservatism: Controlling the effect of industry and year effects 163

Table 6.17 IFRS Adoption and earnings conservatism: Sample with financial year end dated 31 December 164

Table 6.18 IFRS Adoption and earnings conservatism: Sample of firms with Big 4 auditors 166

Table 6.19 IFRS Adoption and earnings conservatism: Sample of firms audited by industry specialist 168

Table 6.20 Time-series test of timeliness in loss recognition: Pre- and post-IFRS adoption 170

Table 6.21 Ownership structure and earnings conservatism 175

Table 6.22 Ownership structure and earnings conservatism: Fama and MacBeth (1973) annual regression 178

Table 6.23 Ownership structure and earnings conservatism: Estimation controlling for industry and year effects 180 
Table 6.24 Ownership structure and time-series test of timeliness in loss recognition

Table 6.25(a) Ownership structure and earnings conservatism: Alternative definitions for family firms and various specifications (Board presence or more than $20 \%$ shares)

Table 6.25(b) Ownership structure and earnings conservatism: Alternative definitions for family firms and various specifications (Board Presence and More than $30 \%$ shares)

Table 6.26(a) Earnings conservatism in Firms under control of the Federal Government of Malaysia: Various specifications 186

Table 6.26(b) Earnings conservatism in Firms under control of State Governments: Various specifications

Table 6.27 Earnings Conservatism: Family firms versus widely-held firms ..... 190

Table 6.28 CEO duality in family firms and earnings conservatism 193

Table 6.29 Time-series test of timeliness in loss recognition: Strategic control of family firms 195

Table 6.30 Corporate governance and earnings conservatism

Table 6.31 Corporate governance and earnings conservatism: An alternative measurement

Table 6.32 Individual corporate governance mechanisms and earnings conservatism

Table 6.33 Corporate governance score and the time-series test of timeliness in loss recognition: Pooled regression, Fama and MacBeth (1973) annual regression, estimation controlling for industry and year effects ...... 207 


\section{List of Figures}

Figure 3.1 Pyramidal structure of a Malaysian firm (Johor Corporation) 61

Figure 4.1 Relationships examined …....................................................... 75

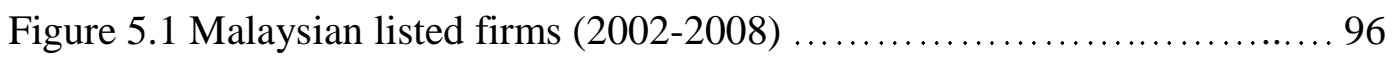

Figure 6.1 P-P Plots for residuals ............................................................ 134

Figure 6.2 Dotplots of residuals ............................................................. 134

Figure 6.3 Asymmetric timeliness of earnings ............................................ 139 


\section{Abbreviations}

\begin{tabular}{|c|c|c|}
\hline FASB & : & Financial Accounting Standards Board \\
\hline GAAP & : & Generally Accepted Accounting Principles \\
\hline GLC & : & Government-Linked Company \\
\hline GLIC & : & Government-Linked Investment Company \\
\hline IASB & : & International Accounting Standards Board \\
\hline IASC & : & International Accounting Standards Committee \\
\hline IAS & : & International Accounting Standards \\
\hline KLSE & : & $\begin{array}{l}\text { Kuala Lumpur Stock Exchange (currently known as } \\
\text { Bursa Malaysia) }\end{array}$ \\
\hline MACPA & : & $\begin{array}{l}\text { Malaysian Association of Certified Public Accountants } \\
\text { (currently known as MICPA) }\end{array}$ \\
\hline MICPA & : & Malaysian Institute of Certified Public Accountants \\
\hline MASB & : & Malaysian Accounting Standards Board \\
\hline MAS & : & Malaysian Accounting Standard \\
\hline NYSE & : & New York Stock Exchange \\
\hline PNB & : & Perbadanan Nasional Berhad \\
\hline PCG & : & Putrajaya Committee on GLC High Performance \\
\hline FRF & : & Financial Reporting Foundation \\
\hline S\&P 500 & : & Standard \& Poor's 500 Index \\
\hline SEDC & : & State Economic Development Corporation \\
\hline SOX & : & Sarbanes-Oxley Act \\
\hline
\end{tabular}




\section{CHAPTER ONE INTRODUCTION}

\subsection{Background and Objectives of the Thesis}

The purpose of this study is to examine the influences on earnings conservatism in Malaysia. The importance of this topic is highlighted because Ball, Robin, and Wu (2003) find no evidence of conservatism in financial statements of Malaysian listed firms, despite the importance of conservatism as key concept underlying accounting practice (Sterling, 1967). Malaysian accounting standards are perceived as being of high quality, because they are derived from UK and IAS standards, however, the weak institutional structures present in earlier years gave little incentive for preparers of financial statements to produce high-quality financial reports, i.e. to follow conservatism (Ball, et al., 2003). After the 1997 Asian financial crisis, the regulatory bodies in Malaysia undertook major reforms in corporate governance and financial reporting to redress the institutional weaknesses. It is therefore appropriate to examine the degree of earnings conservatism following the reforms.

Another major event in the development of financial reporting in Malaysia has been the adoption of International Financial Reporting Standards (IFRS), effective from 1 January 2006. As IFRS tends towards fair value accounting, the degree of 
conservatism (prudence) may be weakened. ${ }^{1}$ This raises the possibility that IFRS could be detrimental if conservatism reduces managers' incentives and ability to manipulate earnings and thus reduces information asymmetry of investors as suggested by LaFond and Watts (2008). Using short-term horizons of one and two years before and after the adoption of IFRS, this thesis examines the impact of IFRS on earnings conservatism in Malaysia.

This study also examines whether firm ownership structure has an influence on earnings conservatism. Given that family firms and state-controlled firms play pivotal economic roles in Malaysia and other East Asian countries, they are likely to also have a unique effect on financial reporting incentives. Different types of firms (family, state-controlled, and widely-held firms) have different stakeholders who face different types of information asymmetry and agency costs, and their managers also have different incentives to report earnings conservatively. It is thus appropriate to examine how the degree of earnings conservatism varies across reporting by different types of firms.

Finally, this study examines the influence of corporate governance on earnings conservatism. Though several studies in developed countries have examined this issue, for example, Beekes, Pope, and Young (2004), García Lara, García Osma,

\footnotetext{
${ }^{1}$ In a handout for both the FASB's July 27, 2005 and the IASB's July 20, 2005 meetings on the conceptual framework (FASB, 2005, p. 24), the FASB responds to questions on "What is the role of conservatism? Does it conflict with neutrality? If not, why not? Why keep it?" with:

"Financial information needs to be neutral - free from bias intended to influence a decision or outcome. To that end, the common conceptual framework should not include conservatism or prudence among the desirable qualitative characteristics of accounting information. However, the framework should note the continuing need to be careful in the face of uncertainty."
} 
and Penalva (2007), and García Lara, García Osma, and Penalva (2009), the literature on the impact of corporate governance on earnings conservatism in Malaysia and other emerging markets remains sparse. While Malaysia introduced the Code on Corporate Governance in March 2000 to improve the quality of governance, no studies have specifically addressed the impact of change in corporate governance practice on earnings conservatism.

\subsection{Significant Contributions of This Thesis}

Basu (1997) introduced the first and most widely used measure of conservatism described as the asymmetric timeliness of earnings measure. It is based on the premise that the practice of conservatism will cause earnings to reflect bad news more quickly than good news. Using the Basu (1997) model, many studies try to provide explanations for differences in conservatism with respect to countryspecific and firm-specific factors. Pope and Walker (1999), for example, find differences in earnings conservatism between the United States and the United Kingdom, while Ball, Kothari, and Robin (2000) compare earnings conservatism between code-law (France, Germany, and Japan) and common-law countries (the United States, the United Kingdom, Canada, and Australia), and find higher earnings conservatism in common-law countries. Extending these studies, this study aims to provide insight on earnings conservatism in an emerging market, i.e. Malaysia. By focusing on a single country, this study avoids several concerns relating to cross-country studies such as the possibility of endogeneity between the variables at the country level, noise in the variables, and severe correlated 
omitted variables problems (Miller, 2004). ${ }^{2}$

More importantly, this approach enables examination of issues specific to a single country, Malaysia, which is an attractive case study for several reasons. First, Malaysia provides a unique setting to examine whether changes in financial reporting incentives affect earnings conservatism. Ball et al. (2003) find no evidence of earnings conservatism in Malaysia and three other East Asian countries, Hong Kong, Singapore, and Thailand, when examining the period from 1984 to 1996 . Though the accounting standards of these countries are perceived as being of high quality ${ }^{3}$, it appears that the weak institutional features of the countries provided poor incentives for managers and auditors to provide highquality financial statements.

Extending Ball et al. (2003), this study focuses on the years 2003 to 2008, the period following the reforms of corporate governance and financial reporting. My point of departure is the suggestion that the institutional structure became much stronger following the various initiatives undertaken by the regulators in Malaysia, some of which occurred in direct response to the Asian financial crisis and others which were reinforced by concerns raised after the crisis. These initiatives included: the Financial Reporting Act 1997; amendment of the

\footnotetext{
${ }^{2}$ According to Miller, a more focused study permits variables to be designed that more cleanly capture the construct being measured, and also frees researchers from the need for variables to be available across a wide range of countries.

${ }^{3}$ Each country has been either substantially influenced in the past by the UK or the US accounting standards, and continues to be influenced by International Accounting Standards (IAS). The accounting standards derived from the United Kingdom, the United States, and the IAS standards are generally viewed as being "high quality" and are associated with timely recognition of economic losses (Ball, et al., 2000).
} 
Securities Law and Bursa Malaysia Listing Requirements; the introduction of the Code of Corporate Governance; and establishment of the Malaysian Accounting Standards Board (MASB), the Malaysian Institute of Corporate Governance (MICG), and the Minority Shareholders Watch Group (MSWG).

Second, this research contributes to a greater understanding of the phenomenon of conservatism, especially the effect of IFRS adoption on earnings conservatism. The implementation of IFRS is expected to reduce earnings conservatism since standard setters perceive conservatism as disturbing the neutrality and relevance of accounting information (Watts, 2003a). In contrast, Watts (2003a) and Ball and Shivakumar (2005) contend that conservatism plays a significant role in contracting, litigation, taxation and regulatory enforcement. In addition, LaFond and Watts (2008) argue that any attempt to eliminate conservatism would increase information asymmetry and hence would reduce the usefulness of accounting information. This study provides evidence as to whether IFRS adoption impacts on earnings conservatism.

Third, this study examines the impact of ownership structure on earnings conservatism. This factor is crucial in the Malaysian business environment, where concentrated ownership structures are the norm (Thillainathan, 1999). Most of the literature on ownership structure focuses on its impact on performance, firm value, and agency cost; but the effect of ownership structure on earnings quality, in the form of earnings conservatism, has received little attention. Given that family firms and state-controlled firms play an important role in the Malaysian economy, it is important to examine the influence of ownership structure on 
earnings conservatism. Several Malaysian studies have examined the influence of family ownership and control on various factors such as performance (Abdul Rahman \& Haniffa, 2005; Abdullah, 2004; Che Haat, 2006), voluntary disclosure (Abdullah \& Mohd Nasir, 2004), and aggressive reporting (Abdul Rahman \& Mohamed Ali, 2006; Yatim, Kent, \& Clarkson, 2006). For state-controlled firms, empirical evidence is very limited; some focus on the impact of state-controlled firms on firm performance (Ang \& Ding, 2006), value (Lau \& Tong, 2008), and earnings management (Yen, Chun, Abidin, \& Noordin, 2007), but none examine earnings conservatism. This study, by constast, examines the impact of family ownership and control and state-control on firm performance (Ang \& Ding, 2006), value (Lau \& Tong, 2008), and earnings conservatism (Yen, et al., 2007), but none examine earnings conservatism.

Finally, this study provides evidence from an emerging market on the relationship between corporate governance and earnings conservatism. Theoretically, conservatism is an outcome of mechanisms to control and monitor managers, thereby enhancing contracting between parties (Watts, 2003a). However, the empirical evidence is limited and focuses primarily on developed countries, such as the United States (Ahmed \& Duellman, 2007; García Lara, et al., 2009), the United Kingdom (Beekes, et al., 2004), and Spain (García Lara, et al., 2007). This study examines the relationship between corporate governance and earnings conservatism in the emerging market, Malaysia. This study contributes to the body of knowledge on corporate governance and the growing empirical literature pertaining to earnings conservatism. The results should also be useful to regulators in deliberating policies on issues related to corporate governance. 


\subsection{Main Empirical Findings}

The first objective of this study is to examine earnings conservatism in Malaysia following the reforms in corporate governance and financial reporting. Using a sample of 3,126 firm-year observations from the period 2003-2008, this study finds evidence of earnings conservatism in Malaysia during during the period under study. This finding stands in contrast to Ball et al. (2003), who find no evidence of earnings conservatism in Malaysia for reporting during the period 1984 to 1996 . The findings of this study are consistent with earnings immediately reflecting 'bad news' received from a negative revision of future cash flows, but delaying the recognition of 'good news' from a positive revision of future cash. These results support the expectation that the institutional reforms, which started from the year 1997, created strong incentives for Malaysian firms to report earnings conservatively.

Secondly, this study examines the impact of the adoption of IFRS on the level of earnings conservatism. The results show no systematic difference beween the levels of earnings conservatism for the short horizon period of one to two years before and after IFRS adoption. This suggests that the change from MASB standards to IFRS standards did not have any significant effect on earnings conservatism. This finding supports the argument of Ball et al. (2003) that accounting standards have less impact on earnings conservatism than do financial reporting incentives.

Thirdly, this study examines how earnings conservatism varies between firms with different types of ownership structure, namely family firms, state-controlled 
firms, and widely-held firms. Since different types of ownership generate different key stakeholders who are subject to different levels and types of agency conflicts, the incentives to report earnings conservatively also vary accordingly. For statecontrolled firms, the results show no evidence of earnings conservatism. This is consistent with the conclusion that state-controlled firms adopt more aggressive accounting. With regard to family firms and widely-held firms, there is evidence of earnings conservatism in both types of firms, indicating that bad news is recognised in a more timely way in accounting earnings than good news. Further investigation shows no statistical difference between the degree of earnings conservatism for family firms and widely-held firms, suggesting that family firms report earnings just as conservatively as do widely-held firms.

This study also examines whether strong control by the family firm in the management and corporate board is associated with the 'convergence of interest' hypothesis, thereby providing stronger incentives to report earnings conservatively. The results support the prediction that strong control by the controlling family of firm management and the board of directors is associated with higher earnings conservatism. This result suggests that family firms have lower agency conflicts and incentives for opportunistic reporting when a member of a controlling family holds the position of both CEO and chairman.

Finally, this study examines the relationship between corporate governance and earnings conservatism. Employing a comprehensive set of corporate governance variables, this study does not find any evidence to link corporate governance and earnings conservatism. This result is contrary to the evidence from developed 
markets, such as the United States and the United Kingdom, where firms with good governance are more timely in recognising bad news. This raises the possibility that the different ownership structures in Malaysia make corporate governance reforms less important.

\subsection{Thesis Organisation}

The remainder of this thesis is organised as follows. Chapter 2 reviews the literature on earnings conservatism, including explanations, constructs, and empirical evidence. An overview of the Malaysian institutional environment with regard to corporate governance, financial reporting, and ownership structure is provided in Chapter 3. Chapter 4 explains the proposed research design and discusses the development of the hypotheses, while Chapter 5 explains the research methodology including the sample, choice of measures for the variables, and the regression models. The descriptive statistics and explanations of the empirical results together with the sensitivity analyses, are presented in Chapter 6. Finally, Chapter 7 summarises the results and acknowledges the limitations inherent in the scope of study and research design. 


\section{CHAPTER TWO \\ EARNINGS CONSERVATISM: A REVIEW OF LITERATURE}

\subsection{Introduction}

This chapter reviews the literature on earnings conservatism, including discussion of the concept, theoretical explanations, constructs, and empirical evidence. The concept of earnings conservatism is discussed in Section 2.2. Section 2.3 outlines theoretical explanations for conservatism from the literature. The development of measures of earnings conservatism is explained in Section 2.4. Section 2.5 discusses the influence of institutional structures on earnings conservatism. Section 2.6 reviews the evidence on firm-specific determinants of earnings conservatism. The chapter is summarised Section 2.7.

\subsection{Concepts of Conservatism}

Basu (1997) interprets conservatism as “capturing accountants' tendency to require a higher degree of verification for recognizing good news than bad news in the financial statements" (p.4). To differentiate this interpretation from the general explanation of conservatism, as used in accounting textbooks and standard-setters' publications, empirical studies refer to this concept as earnings conservatism (García Lara \& Mora, 2004), conditional conservatism (Ball, et al., 2000; Ball \& Shivakumar, 2005), ex-post conservatism (Richardson \& Tinaikar, 2004), and news-dependent conservatism (Chandra, Wasley, \& Waymire, 2004). To measure earnings conservatism, the Basu (1997) model regresses accounting earnings on stock returns where stock returns serve as a proxy for economic news. 
Given that stock prices efficiently capture all types of economic news, and earnings conservatism results in asymmetric recognition of good news and bad news; the result must be a higher coefficient for negative stock returns (bad news) than for positive stock returns (good news). The difference between the coefficients is the measure of conservatism. Examples of earnings conservatism include the lower of cost or market rule for inventory, impairment accounting for non-current tangible assets, and the write-down (impairment) of goodwill.

Earnings conservatism has several important economic roles. Generally, contractual relations, litigation, regulatory incentives, and the relationship between taxation and financial reporting influence the incentives for conservative reporting (Watts, 2003a). In terms of contracting, earnings conservatism facilitates more efficient contracting by restricting management's opportunistic reporting behaviour (Qiang, 2007; Watts, 2003a). Earnings conservatism helps protect the interest of fund providers. Debtholders, for instance, demand timely information about bad news since the option value for their claims is highly sensitive to a fall in firm value (Basu, 1997). In addition, by reporting earnings conservatively, managers reduce litigation risk (Ball, 2001; Ball \& Shivakumar, 2005). Previous studies also find that international differences in earnings conservatism are linked to differences in countries' corporate governance regimes and regulatory infrastructure (Ball, et al., 2000; Bushman \& Piotroski, 2006; Giner \& Rees, 2001).

The second type of conservatism is referred to as unconditional conservatism (Beaver \& Ryan, 2005), news-independent conservatism (Chandra, et al., 2004) 
and ex-ante conservatism (Pope \& Walker, 2003). Unconditional conservatism arises because of the accounting rules, accounting choices, and procedures that cause an understatement of book value and earnings (Easton \& Pae, 2004), and thus yield expected unrecorded goodwill (Beaver \& Ryan, 2005). This is consistent with Feltham and Ohlson (1995) who define conservatism as a persistent understatement of shareholders' equity relative to market value. In the extreme form, unconditional conservatism causes investments to trigger expense recognition, but not asset recognition (Pope \& Walker, 2003, p. 2). Examples of unconditional conservatism include aggressive depreciation of property, plant, and equipment, immediate expensing of internally developed intangibles, and the use of historical cost accounting for positive net present value projects. Gassen, Fülbier, \& Sellhorn (2006), however, argue that the economic functions of unconditional conservatism are far less obvious. Further, Ball and Shivakumar (2005) state that "While unconditional conservatism seems inefficient or at best neutral in contracting, conditional conservatism (timely loss recognition) can enhance contracting efficiency" (p. 91). For instance, the accumulation of cookiejar reserves from continuous understatement of assets increases discretionary freedom of management, especially to mask negative developments (Gassen, et al., 2006).

\subsection{Theoretical Explanations for Conservatism}

Watts (2003a) provides four explanations for conservatism: contracting, litigation, taxation and regulation. Of the four explanations, contracting is more extensively discussed in Watts (2003) because it is the earliest source of conservatism recognised in the literature; and the arguments related to it are more fully 
developed compared to the others. Discussions on the four explanations for conservatism together with a review of recent evidence are provided in the following sections.

\subsubsection{Contracting}

The first recognised explanation for conservatism is contracting (Watts, 2003a). Since debtholders have an asymmetric payoff with respect to net assets, they are interested in the lower end of the possible values of earnings and net assets. For example, in the case of liquidation, debtholders would receive less than the contracted sum if the net asset value is below the face value of the debt. The limited liability of shareholders and managers restrains managers from claiming their losses. Thus, to protect their investment, debtholders may request more conservative reporting of earnings and impose a strict debt covenant that includes a dividend covenant and a minimum requirement on net assets. Earnings conservatism thus promotes a more efficient debt covenant, including restricting excessive payment of dividends to shareholders. In addition, the debt contract may set a lower bound measure on net assets to trigger technical default, thereby constraining managers from making decisions that could reduce the value of net assets (Beneish \& Press, 1993).

Management compensation and employment contracts also contribute to conservatism. Given that managers have more information than other parties, conservatism is essential to reduce managers' upwardly biased estimate of future cash flows, which can lead to overpayment of compensation to managers. Earnings-based compensation plans, create incentives for managers to report 
higher earnings, achieved by delaying the recognition of bad news and accelerating the recognition of good news. Moreover, managers have a higher propensity to opt for negative net present value (NPV) investments with larger positive immediate returns. Further, because of limited tenure and liability of managers, it is almost impossible to recover overpayment of compensation, or secure damages, from a poor investment decision made by managers. Even with a court order, the full cost of the action could well be larger than the manager's wealth (Watts, 2003a). In short, earnings conservatism has a pivotal role in mitigating the managers' opportunistic reporting behaviour and alleviating agency conflicts.

From a corporate governance perspective, earnings conservatism facilitates more effective monitoring of the board of directors, shareholders and debtholders. Given that managers have higher incentives to defer the recognition of future economic losses, conservatism helps to issue an early warning to the board of directors and shareholders by accelerating the recognition of economic losses. As a result, prompt corrective action, including terminating poorly performing managers and discontinuing negative NPV projects, can be undertaken to minimise losses and risks.

Many empirical studies support the contracting explanation on earnings conservatism. Qiang (2007), for example, finds that contracting induces earnings conservatism. Ahmed, Billings, Morton, and Stanford-Harris (2002) find that conservatism mitigates bondholder-shareholder conflicts over dividend policy. Furthermore, they find a lower cost of debt in firms with higher accounting 
conservatism. In short, this evidence supports the argument earnings conservatism can facilitate contracting.

\subsubsection{Litigation}

Watts (2003a) proposes a litigation explanation for conservatism. García Lara et al. (2009) contend that conservatism reduces litigation risk for managers, directors, and auditors. Prior studies on auditor litigation find that lawsuits against auditors often relate to non-conservative reporting such as overstatements of earnings or net assets (Kellogg, 1984; St. Pierre \& Anderson, 1984) and high earnings-increasing abnormal accruals (Heninger, 2001). Thus, managers will err on the side of conservative reporting to alleviate litigation risk (Chung, Firth, \& Kim, 2003), especially when the courts are more likely to award damages for overstated earnings or assets (Kellogg, 1984). At the same time, auditors also have greater incentives for conservative reporting of earnings as litigation against firms and auditors has become more common and more costly (DeFond \& Subramanyam, 1998).

Numerous studies support the effect of litigation on earnings conservatism. Qiang (2007), for example, finds litigation induces both earnings conservatism and unconditional conservatism. In the United Kingdom, Huijgen and Lubberink (2005) find greater earnings conservatism among firms that are cross-listed in a more litigious country (the United States) than among UK firms without a US listing. Al-Sehali and Spear (2004) find no evidence of earnings conservatism in Saudi Arabia, where expected litigation costs are low. In an auditing study, Cahan and Zhang (2006) find that ex-Andersen clients have greater conservatism, which 
is consistent with the view that an Andersen's audit is a unique source of litigation risk. Greater conservatism is also observed during periods of higher auditor liability (Basu 1997) and among firms hiring big audit firms (Basu, Hwang, \& Jan, 2001).

\subsubsection{Taxation}

Taxation rules may influence accounting practices. Watts (2003a) argues that "asymmetric recognition of gains and losses enables managers of profitable firms to reduce the present value of taxes and increase the value of firms" (p. 209). As such, firms would report low earnings (by accelerating the recognition of expenses and delaying the recognition of revenues) to minimise current tax obligations. Extant studies show the relationship between taxation and conservatism. Hellman (2008), for instance, finds that the link between accounting and taxation is stronger in code-law countries; hence those countries are linked to higher earnings conservatism (Ball, et al., 2000).

\subsubsection{Regulation}

The fourth explanation for conservatism is regulation. Regulation has a significant role in influencing the incentives for conservative reporting (Watts, 2003a). Governments, through legislation, and the accounting profession, through accounting standards, set and enforce conservative accounting rules. The rationale for these rules is to protect the interests of investors and creditors, thus ensuring well-functioning share and credit markets (Chung, et al., 2003). For instance, the over valuation of the New York Stock Exchange (NYSE) in 1929 caused the SEC 
ban on upward valuation of assets (Walker, 1992; Watts, 2003a). Accounting rules, such as goodwill amortisation, also lead to conservative reporting in the United States.

Many empirical studies support the above arguments. Sivakumar and Waymire (2003) find that enforceable accounting rules induce conservatism, while Qiang (2007) finds that regulation induces conservatism. Recently, Lobo and Zhou (2006) examined earnings conservatism levels following the adoption of the Sarbanes-Oxley Act (SOX), and find higher earnings conservatism following SOX. Bushman and Piotroski (2006) examine the effect of legal and political institutions on financial reporting incentives, and find that both factors significantly influence the level of earnings conservatism.

\subsection{Development of Earnings Conservatism Measures}

This section explains several measures of earnings conservatism employed in empirical studies. The measures include the Basu (1997) asymmetric timeliness of earnings measure, the time-series test of loss recognition model (Basu, 1997), the accruals-based test of loss recognition model (Ball \& Shivakumar, 2005), and the firm-year estimate for conservatism (Francis, LaFond, Olsson, \& Schipper, 2004; Khan \& Watts, 2009). In addition to the above measures, studies also employ the market to book ratio (Roychowdury \& Watts, 2007), hidden reserve measure (Penman \& Zhang, 2002), and negative accruals measure (Givoly \& Hayn, 2000). However, I exclude the discussion of the last three models from this study since the convergent validity tests conducted by Wang, Ó Hógartaigh, and van Zijl (2009) suggest that these measures are from a different group of conservatism 
measures.

\subsubsection{The Asymmetric Timeliness of Earnings Model - Basu (1997)}

In the Basu (1997) model, conservatism is defined as the extent to which current period accounting earnings asymmetrically incorporate economic losses relative to economic gains. With that notion, the following equation is regressed to test the difference in the timeliness of good news and bad news.

$$
E_{i} / P_{i t-1}=\beta_{0}+\beta_{1} R E T_{i t}+\beta_{2} R D_{i t}+\beta_{3} R E T_{i t} * R D_{i t}+\varepsilon_{i t}
$$

where $E_{i t}$ is the earnings per share for firm $\mathrm{i}$ in fiscal year $\mathrm{t}$; $P_{i t-1}$ is the price per share at the beginning of the fiscal year; $R E T_{i t}$ is the annual return of firm $\mathrm{i}$ in fiscal year $\mathrm{t}$; $R D_{i t}$ is a dummy variable that equals 1 if $R E T_{i t}$ is negative, and 0 otherwise; and $\varepsilon_{i t}$ is the error term.

The coefficient $\beta_{1}$ measures the response of earnings to returns when returns are positive, and $\beta_{1}+\beta_{3}$ measures the response of earnings to negative returns. If $\beta_{1}+\beta_{3}>\beta_{1}$ or $\beta_{3}>0$, then earnings reflect bad news more quickly than good news, and thus $\beta_{3}$ measures earnings conservatism.

In this model, stock return acts as a proxy for economic income, assuming that stock prices reflect all available information. This is consistent with the evidence that stock prices lead earnings information (Ball \& Brown, 1968; Kothari \& Sloan, 1992). Accounting earnings, however, employs different verification standards for recognising bad news (negative stock returns) and good news 
(positive stock returns), and this generates earnings conservatism. For bad news, lower verification standards are used, which results in immediate recognition of losses. For good news, higher verification standards are imposed which cause delay in recognising economic gains. These asymmetric verification standards lead to more timely reporting of bad news relative to good news.

Basu's (1997) reverse regression model has been the most widely used measure of earnings conservatism in empirical research. Among the studies that have employed this model are Ball et al. (2000), Ball et al. (2003), Ball and Shivakumar (2005), Bushman and Piotroski (2006), Francis et al. (2004) and Roychowdury and Watts (2007). Despite the wide acceptance, this model is subject to some criticisms (Bushman \& Piotroski, 2006; Dietrich, Muller, \& Riedl, 2007; Gigler \& Hemmer, 2001).

First, Bushman and Piotroski (2006) criticise the effectiveness of the model since it places heavy reliance on the assumption that stock prices capture all economic gains and losses. Given that the price formation process is not equally efficient across all markets (Morck, Yeung, \& Yu, 2000), the effectiveness of the Basu model can be questioned. Furthermore, Gigler and Hemmer (2001) argue that stock returns might not reflect all non-earnings news, and might also reflect good and bad economic news differentially, possibly as a function of a firm's own disclosure policies. If the equity is mispriced, then the model is likely to have measurement error.

Second, Dietrich et al. (2007) claim that the Basu regression is biased and hold 
that the inferences made from this model should not be relied upon. The bias is derived from the choice of deflator for the variables in the regression and the partitioning occurring on the basis of an endogenous variable (i.e. negative or positive stock returns). This endogeneity is allegedly attributable to the fact that accounting income has an effect on stock returns (Lai \& Taylor, 2008). Despite all the criticisms, Ryan (2006) concludes that the asymmetric timeliness of earnings model is still the best measure of earnings conservatism available. However, Ryan does encourage the use of multiple measures for earnings conservatism. I use the asymmetric timeliness of earnings measure of conservatism as the primary measure in the test of my hypotheses, outlined in Chapter 6.

\subsubsection{The Time-Series Test of Loss Recognition - Basu (1997)}

The second measure in Basu's (1997) study examines the time-series behaviour of earnings changes. This model has been used in several studies including Ball et al. (2000), Ball et al. (2003), Ball and Shivakumar (2005), Ruddock, Taylor, and Taylor (2006) and Jenkins and Velury (2008). This measure exploits the transitory nature of economic income (Samuelson 1965; Fama, 1970). Basu (1997) argues that while bad news affects earnings immediately, the effect does not persist. On the other hand, good news takes longer to be reflected in earnings, but the effect is more likely to persist in future periods. Thus, the transitory gain and loss components measure the tendency for increases and decreases in accounting income to reverse (Basu, 1997).

The time-series test of loss recognition model assumes that a decrease in current earnings during a bad news period is likely to reverse in the next period. Thus, it 
is expected that the reporting of bad news is associated with an increase in negative autocorrelation between current and future earnings. Good news, however, is recognised over several periods. Thus, an increase in current earnings during a good news period is more persistent, while a decrease in earnings is more transitory in nature. Consistent with conservatism arguments, prior studies (for example Basu, 1997; Brooks \& Buckmaster, 1976; Elgers \& Lo, 1994) find that negative earnings changes are more likely to reverse in the following period than positive earnings changes. To identify the transitory gain and loss components in earnings, Basu (1997) estimates the following linear regression.

$$
\Delta N I_{i t}=\alpha_{0}+\alpha_{1} \Delta N I_{i t-1}+\alpha_{2} D \Delta N I_{i t-1}+\alpha_{3} \Delta N I_{i t-1} * D \Delta N I_{i t-1}+\varepsilon_{i t}
$$

where $\Delta N I_{i t}$ is the change in earnings for firm $\mathrm{i}$ from year t-1 to year $\mathrm{t}$, standardised by total assets at end of year $\mathrm{t}-1 ; D \wedge N \mathrm{I}_{i t-1}$ is a dummy variable equal to 1 if $\Delta N I_{i t-1}$ is negative, and 0 otherwise; and $\varepsilon_{i t}$ is the error term.

In equation (1.2), a reversal of transitory gains or losses from the prior period would result in a negative coefficient. If the recognition of economic gains in earnings is deferred until the underlying increases in cash flows are realized, then the gains to be recognised as 'persistent' positive components of earnings tend not to reverse. Hence, the implication is $\alpha_{l}=0$. For economic losses, conservative accounting results in early recognition of economic losses in earnings, hence the transitory income decreases tend to reverse in the future: the implication being $\alpha_{2}+\alpha_{3}<0$. If economic losses are recognised in a more timely fashion than are gains, the coefficient $\alpha_{3}$ is expected to be negative. I use the time-series test of loss recognition as an alternative means of testing my hypotheses. 


\subsubsection{Accruals-Based Test of Loss Recognition - Ball and Shivakumar (2005)}

Ball and Shivakumar (2005) examine differences in earnings conservatism between public and private firms. Since stock price information is not available for private firms, Ball and Shivakumar (2005) developed an accruals-based test of loss recognition as an alternative measure for earnings conservatism. This model assumes that the asymmetry arises because economic losses are recognised on a timely basis as unrealized (i.e., non-cash) accrued charges against earnings. In contrast, economic gains are recognised only when they are realized. From this argument, Ball and Shivakumar (2005) estimate the following piecewise-linear relation between cash flows and accruals in order to measure earnings conservatism.

$$
A C C_{i t}=\beta_{0}+\beta_{1} D C F O_{i t}+\beta_{2} C F O_{i t}+\beta_{3} D C F O_{i t} * C F O_{i t}+\varepsilon_{i t}
$$

where $C F O_{i t}$ is measured as earnings before exceptional and extraordinary items less accruals of firm i in fiscal year t; $D C F O_{t}$ is a dummy variable that takes value 1 if $C F O_{t}$ is negative and 0 otherwise; and $\varepsilon_{i t}$ is the error term. While $A C C_{i t}$ is measured as:

$$
\begin{aligned}
A C C_{t}= & \text { Ninventory }+\Delta \text { Debtors }+\Delta \text { Other current assets } \\
& -\Delta \text { Creditors }-\Delta \text { Other current liabilities } \\
& - \text { Depreciation }
\end{aligned}
$$

Both variables, accruals and cash flow from operations, are standardised by total assets at the beginning of the period. 
This model predicts a negative coefficient for cash flows $\beta_{2}$ and a positive incremental coefficient $\beta_{3}$ for negative cash flows is consistent with the argument that accrued losses are more likely in periods of negative cash flows.

\subsubsection{Firm-Year Measure - Francis, LaFond, Olsson, and Schipper (2004)}

Based on Basu's asymmetric timeliness of earnings model, Francis, et al. (2004) introduce the firm-year measure of conservatism by estimating equation (1.5) on a firm- and year-specific basis using rolling ten-year windows.

$$
E A R N_{j, t}=\alpha_{0, j}+\alpha_{1, t} N E G_{j, t}+\beta_{1, j} R E T_{j, t}+\beta_{2, j} N E G_{j, t} * R E T_{j, t}+\varepsilon_{t}
$$

where $E A R N_{j, t}$ is firm income before extraordinary items in year t, scaled by market value at the end of year $\mathrm{t}-1 ; R E T_{j, t}$ is firm's 15 -month return ending three months after the end of fiscal year $\mathrm{t} ; N E G_{j, t}$ is 1 if $R E T_{j, t}$ is negative and 0 otherwise; and $\varepsilon_{t}$ is the error term.

Consistent with Basu (1997), Pope and Walker (1999), and Givoly and Hayn (2000), Francis et al. (2004) measure conservatism using the negative of the ratio of the coefficient on bad news to the coefficient on good news, Conservatism= $\left(\beta_{1, j}+\beta_{2, j}\right) \beta_{1, j}$. Larger values of Conservatism imply lower conservative earnings.

\subsubsection{Firm-Year Measure - Khan and Watts (2009)}

Khan and Watts (2009) introduce a firm-year measure for earnings conservatism (C_Score) by extending the Basu (1997) reverse regression model. Khan and Watts (2009) estimate equation (1.6), which allows coefficients to vary across 
firms and over time. In this model, the timeliness of good news and incremental timeliness of bad news are assumed to be linear functions of time-varying firmspecific characteristics for which Khan and Watts suggest namely Size, MTB, and $L E V$.

$$
\begin{aligned}
X_{i t}= & \beta_{1}+\beta_{2} D_{i}+R_{i}\left(\mu_{1}+\mu_{2} \text { Size }_{i}+\mu_{3} M T B_{i}+\mu_{4} \text { Lev }_{i}\right) \\
& +D_{i} R_{i}\left(\lambda_{1}+\lambda_{2} \text { Size }_{i}+\lambda_{3} \text { MTB }_{i}+\lambda_{4} \text { Lev }_{i}\right)+\delta_{1} \text { Size }_{i}+\delta_{2} M T B_{i} \\
& +\delta_{3} \text { Lev }_{i}+\delta_{4} D_{i} \text { Size }_{i}+\delta_{5} D_{i} \text { MTB }_{i}+\delta_{6} D_{i} \text { Lev }_{i}+\varepsilon_{i t}
\end{aligned}
$$

where $X$ is earnings; $R$ is returns; $D$ is a dummy variable that equals 1 if $R$ is negative, and 0 otherwise; Size is the natural log of market value of equity; Lev is the ratio of long-term and short-term debt deflated by market value of equity; $M T B$ is the market to book ratio; $i$ is indexes the firm; and $\varepsilon$ is the residual.

From the estimation, the timeliness of good news (G_Score) and conservatism (C_Score) are calculated using the following equations:

$$
\begin{aligned}
& G_{-} \text {Score }=\beta_{3}=\mu_{1}+\mu_{2} \text { Size }_{i}+\mu_{3} \text { MTB }_{i}+\mu_{4} \text { Lev }_{i} \\
& C_{-} \text {Score }=\beta_{4}=\lambda_{1}+\lambda_{2} \text { Size }_{i}+\lambda_{3} M T B_{i}+\lambda_{4} \text { Lev }_{i}
\end{aligned}
$$

where $\lambda_{i}$ and $\mu_{i}, i=1$ to 4 , are constant across firms, but vary over time.

Khan and Watts (2009) also provide evidence on the empirical properties of C_Score. The result shows that a higher C_Score is associated with higher Basu (1997) earnings conservatism, more negative return on earnings and more variable non-operating accruals, suggesting the validity of the $C_{-}$Score measure. 
Consistent with predictions in prior literature, Khan and Watts (2009) find that firms with a higher C_Score have higher information asymmetry, longer investment cycles, greater idiosyncratic uncertainty and greater probability of litigation. Lai and Taylor (2008) estimate and validate Khan and Watts' C_Score measure for conservatism (based on the 2007 working paper version) using an Australian sample. They find that the C_Score is positively associated with stock return volatility, investment cycle length and prior period conservatism. In addition, they find that the C_Score is negatively associated with firm size, firm age, and leverage.

\subsection{Institutional Structure and Earnings Conservatism}

Since the seminal work of Basu (1997) on earnings conservatism, numerous cross-countries studies have been conducted to examine how institutional structure influences earnings conservatism. The following studies provide evidence that institutional structure, including the legal/judicial system, securities laws, and political economy, create incentives that influence the behaviour of corporate executives, investors, regulators and other market participants, which indirectly shape the properties of accounting numbers, in particular earnings conservatism.

Ball et al. (2000) examine earnings conservatism in code-law and common-law countries that include seven international GAAP regimes (Australia, Canada, United States, United Kingdom, France, Germany and Japan). The study documents substantial variation in asymmetric timeliness of earnings across regimes, where common-law countries exhibit higher earnings conservatism than 
code-law countries. This result suggests legal and institutional environments have a significant influence on earnings conservatism in the countries examined. Ball et al. (2000) argue that enhanced common-law disclosure standards reduce the agency costs of monitoring managers, thus countering the advantage of closer shareholder-manager relationships in code-law countries. Another study by Giner and Rees (2001) examines earnings conservatism in three distinct legal traditions: French code (or civil) law, German code-law and English common law. The results show that earnings conservatism is stronger in the United Kingdom than in France or Germany. By concentrating on European countries, Giner and Rees (2001) minimise the impact of other social and economic differences and thereby isolate legal and accounting effects more clearly.

Extending the previous studies, Bushman and Piotroski (2006) examine the influence of legal and political institutions on earnings conservatism using a sample of firms from 38 countries from 1992 to 2001. They find that firms in countries with a high-quality judicial system recognise bad news in a more timely fashion than firms in countries with a low-quality judicial system. In addition, strong public enforcement of securities is positively associated with slowness in the recognition of good news, while private enforcement of securities law has no effect on conservatism. In terms of state involvement in the economy, evidence from common-law countries (civil-law countries) reveals that firms facing high state involvement in the economy report earnings aggressively (conservatively). This evidence suggests that managers adjust their financial reporting in response to legal and political institutions. 
In the United States, Lobo and Zhou (2006) examine the effect of the introduction of the Sarbanes-Oxley Act (SOX) on earnings conservatism. Since SOX requires the $\mathrm{CEO}$ and $\mathrm{CFO}$ of all exchange-listed firms to certify the material accuracy and completeness of their firms' financial statements, SOX increases litigation risk, thereby providing greater incentives to report earnings conservatively. Consistent with the prediction, Lobo and Zhou (2006) find an increase in earnings conservatism in financial reporting following SOX. In addition, post-SOX financial reports have lower discretionary accruals than those in the period preceding SOX.

Raonic, McLeay, and Asimakopoulos (2004) assess the impact of country-level disclosure regimes, legal enforcement, and the importance of equity markets on earnings conservatism of European firms. They find higher earnings conservatism for firms domiciled and listed in different markets, showing a varying level of earnings sensitivity to market news. This is partly due to the interaction between the different institutional factors that drive the demand for accounting earnings recognition. In short, the study concludes that regulatory enforcement is positively associated with the bias towards conservatism while equity market exposure appears to be positively associated with greater timeliness in earnings recognition.

Grambovas, Giner, and Christodoulou (2006) extend Ball et al. (2000) and Raonic et al. (2004) by providing further evidence on earnings conservatism from the United States and from European Union (EU) countries. They find earnings have become more conservative in the EU as well as the United States. However, there is little evidence on differences in earnings conservatism between the two regions. 
From the results, they argue that the changes in this property of earnings in both regions are attributable to a common factor that affects firms in both locations and is not limited to the economic convergence process that happened in EU countries.

Numerous studies have documented evidence that accounting standards have a significant impact on earnings conservatism. Accounting standards play a critical role in corporate governance by informing investors and by making contracts more verifiable (La Porta, Lopez-de-Silanes, Shleifer, \& Vishny, 1998). A study by Pope and Walker (1999), which assesses the differences between conservatism in the United States and the United Kingdom, finds differences in the timeliness of income recognition in the two regimes operating under separate sets of accounting standards. In the United Kingdom, the write-offs of large transitory losses through extraordinary items was tolerated before the introduction of FRS No. 3 in 1993; however, in the United States, those items would be classified as components of ordinary earnings. The results suggest that the incentives facing UK firms to classify bad news earnings components as extraordinary items were strong over the sample period. Barth, Landsman, and Lang (2008) examine whether the application of International Accounting Standards (IAS) in 21 countries is associated with higher accounting quality. They find that firms applying IAS have more timely loss recognition, less earnings management, and more value relevance of accounting information, than firms applying non-US domestic standards. 


\subsection{Firm-Specific Factors and Earnings Conservatism}

Apart from cross-country studies on earnings conservatism, several studies provide explanations on variation in the level of earnings conservatism as results of firm-specific factors. These studies include, among others, factors relating to firm ownership, external auditors, and board of directors.

\subsubsection{Firm Ownership}

Empirical studies find that firm ownership has a significant effect on earnings conservatism. Ball and Shivakumar (2005), for instance, examine whether public or private firms in the UK have different levels of earnings conservatism. Both types of firms are subject to similar auditing regulation, but the results show that private firms report with less earnings conservatism. Specifically, the results show that the asymmetric timeliness of earnings is lower in private firms than in public firms. Ball and Shivakumar's (2005) study suggests that different market demand affects earnings conservatism even though both types of firms are subject to the same basic rules.

In the United States, Wang (2006) examines the relationship between founding family ownership and earnings quality on data from S\&P 500 firms during the period 1994-2002. The findings show that, on average, founding family ownership has higher earnings quality, measured using various proxies including earnings conservatism. In terms of earnings conservatism, founding family firms have lower persistence of transitory loss components in earnings, implying higher earnings conservatism. In addition, founding family firms exhibit lower abnormal 
accruals and greater earnings informativeness, implying an effect of family ownership on earnings quality.

Subsequently, Ahmed and Duellman (2007) examine whether outside directors' shareholdings have a significant influence on conservatism. Given that the presence of outside directors is crucial in promoting board independence, holding significant equity stakes would provide additional incentives for the outside directors to monitor (and if necessary confront) managers (Jensen, 1993). Using a sample from the S\&P 500 over the fiscal years 1999-2001, Ahmed and Duellman (2007) find a positive relationship between outside directors' shareholdings and conservatism, thus supporting the prediction.

Recently, LaFond and Roychowdury (2008) examine the effect of managerial ownership on earnings conservatism. Given that earnings conservatism is a potential mechanism to address agency conflicts, LaFond and Roychowdury hypothesise that when managerial ownership declines, the severity of agency conflicts increases; and hence increase the demand for conservatism. Consistent with this prediction, the results show that, as managerial ownership declines, earnings become more conservative. This result shows that when managers have increased incentives to overstate gains and understate losses and are less exposed to the consequences of their actions, shareholders would demand more conservative reporting.

\subsubsection{Auditors}

Some studies argue that auditors could indirectly affect the quality of financial 
statements through their influence on clients' accounting choices (Becker, Defond, Jiambolvo, \& Subramanyam, 1998; DeFond \& Subramanyam, 1998). Given that the courts are more likely to award damages for overstated earnings or assets (Kellogg, 1984), auditors generally have a preference for conservative reporting. Auditors would be expected to place pressure on the client to report earnings conservatively in order to reduce the litigation risk. The extent of auditors' influence over the clients' financial reporting could vary, depending on auditor attributes such as auditor size, audit tenure, industry specialisation, and the provision of non-audit services.

Basu et al. (2001) examine the effect of the size of the audit firm on earnings conservatism. Since Big Eight audit firms have greater exposure to legal liability (Thoman, 1996), Basu et al. (2001) predict that Big Eight auditors are more conservative than auditors who are not members of the Big Eight. The result from the Basu (1997) reverse regression model shows that the difference in the timeliness of earnings to good and bad news is greater for Big Eight audit clients, implying higher earnings conservatism. Further, earnings conservatism in Big Eight audit clients increases more than it does in non-Big Eight audit clients in a period of high liabilities, suggesting that Big Eight auditors are more sensitive to liabilities exposure. The result holds even after matching observations by year, industry and size.

Extending Basu et al. (2001), Chung, Firth, and Kim (2003) examine the role of auditors in influencing a more conservative accounting in their clients' financial reporting. They contend that the economic performance of the client and the size 
of audit firms determine the insistence of auditors on conservatism and the ability auditors have to force their clients to comply with their requests. Consistent with the prediction, the results show that Big Six audit clients report more conservative earnings than do non-Big Six audit clients only when the clients' financial performance is worse than expected.

Krishnan (2005a) examines the role of auditor-industry specialisation on earnings conservatism. Previous studies argued that auditor-industry expertise is associated with higher audit quality (O'Keefe, King, \& Gaver, 1994). It is argued that industry specialists gain experience and accumulate industry-based knowledge that are precursors to superior audit judgment quality (Bédard \& Biggs., 1991; Bonner \& Lewis, 1990). Consistent with the prediction, Krishnan finds clients of specialist auditors have higher earnings conservatism than clients of non-specialist auditors. This implies that auditors' industry expertise moderates the clients' tendency to delay the recognition of economic losses.

Johnson, Khurana, and Reynolds (2002) examine the effect of audit-firm tenure on earnings conservatism. Using two proxies for conservatism, they find a positive association between earnings conservatism and the length of the auditorclient relationship. Specifically, they find an increase in conservatism between short audit-firm tenure (one to three years) and medium audit-firm tenure (four to eight years). However, the study finds no evidence of reduced conservatism for longer audit-firm tenures of nine or more years. These results imply lower conservatism for short auditor tenure, and thus provide evidence that mandating auditor rotation may adversely affect the quality of financial reports. 
One of the controversial aspects in auditing and financial reporting studies is related to non-audit services. The provision of non-audit services by incumbent auditors is alleged to impair auditor independence. To provide more insight on this issue, Ruddock, Taylor, and Taylor (2006) examine whether high levels of non-audit fees is associated with reduced earnings conservatism. Their findings show that higher-than-expected levels of non-audit services are not associated with reduced conservatism. This result is robust even after using various proxies for economic news and conducting comprehensive sensitivity tests.

Another issue that has attracted researcher attention is the indictment of Arthur Andersen, one of the biggest audit firms in the world. Krishnan (2005b) examines the timely reporting of bad news by Arthur Andersen's Houston-based clients. Using a control group consisting of Houston-based clients audited by other Big Six auditors, this study finds that Arthur Andersen clients are less timely in reporting bad news. This result suggests that the clients of Arthur Andersen's Houston office engaged in aggressive accounting practices i.e. delayed recognition of publicly available bad news.

Subsequently, Cahan and Zhang (2006) examine accounting conservatism of exAndersen clients following the demise of Arthur Andersen. The study posits that successor auditors demanded their ex-Andersen clients apply more conservative accounting so as to reduce litigation risk. The analysis shows ex-Andersen clients had larger decreases in abnormal accruals in the year 2002, after Arthur Andersen's demise. This result is consistent with auditor conservatism, in which the successor auditors perceive the Andersen audit as a unique source of litigation 
risk. Krishnan (2007) reports a similar finding when examining the level of earnings conservatism of the former Andersen clients when they were forced to switch auditor in 2002. This study finds that, before the switch of auditor, earnings of former Andersen clients were less conservative relative to earnings of non-Andersen clients. However, after the switch of auditor, earnings conservatism increase for the former Andersen clients but not for the control sample clients. These findings suggest that auditors and managers employ earnings conservatism as a risk-management strategy in the post-Andersen era.

\subsubsection{Board of Directors}

The board of directors is the apex of the monitoring and control system of large firms (Fama \& Jensen, 1983). Conservative accounting information assists the board of directors in reducing deadweight losses resulting from agency problems and alleviates agency conflicts between contracting parties (Watts, 2003a). Hence, many studies examine the link between characteristics of the board of directors' and earnings conservatism.

In the United States, Ahmed and Duellman (2007) investigate the relationship between accounting conservatism and characteristics of the board of directors, in particular, board independence and the strength of outside directors' monitoring incentives. The results from S\&P 500 firms over the fiscal years 1999-2001 show a negative relationship between conservatism and the proportion of inside directors on the board. In addition, they find a positive relationship between outside directors' shareholdings and conservatism, showing that ownership of shares by outside directors enhances their monitoring incentives. These results 
suggest that both factors, board independence and the strength of outside directors' monitoring incentives, facilitate greater monitoring of managers that leads to more conservative reporting.

Beekes et al. (2004) report a similar finding in a UK study. Using listed nonfinancial firms from 1993 to 1995, they examine the relationship between board composition (in terms of the proportion of outside directors) and earnings quality, measured using earnings timeliness and conservatism. The results show higher earnings conservatism in firms with a relatively high proportion of outside directors. This finding implies that board composition is a crucial factor in determining earnings quality in the United Kingdom.

In Spain, García Lara et al. (2007) investigate whether CEO influence over the board has a significant effect on earnings conservatism. As proxies for the influence of the CEO over the board of directors, this study employs two aggregate indexes incorporating six and eight variables relating to the board of directors and monitoring committees. The variables include board size, nonexecutive directors, independent directors, executive chairman, board meetings, audit committee, nomination/remuneration committee and an executive committee. The results show that firms with a low level of CEO influence over the board exhibit higher earnings conservatism than firms with higher CEO influence over the board. This implies the importance of board independence in promoting greater earnings conservatism.

Recently, García Lara et al. (2009) examine the relationship between corporate 
governance and earnings conservatism in the US from 1992 to 2003. To capture the strength of corporate governance, this study employs a composite measure that includes various internal and external corporate governance components. The results show that firms with strong corporate governance exhibit higher earnings conservatism. Further tests on the endogenous nature of corporate governance find that the direction of causality flows from governance to conservatism, and not vice versa. This implies that governance and conservatism are not substitutes.

\subsection{Chapter Summary}

This chapter has reviewed the literature on earnings conservatism. This includes discussion of the concept of conservatism and explanations for accounting conservatism. This chapter also includes explanations of various earnings conservatism measures employed in previous studies and reviews the empirical evidence, especially the influence of institutional structures and firm-specific factors on earnings conservatism.

The next chapter provides an overview of the Malaysian institutional environment, including corporate governance, financial reporting, and ownership structure. 


\section{CHAPTER THREE \\ MALAYSIAN INSTITUTIONAL BACKGROUND: \\ CORPORATE GOVERNANCE, FINANCIAL REPORTING, AND OWNERSHIP STRUCTURE}

\subsection{Introduction}

This chapter examines the Malaysian institutional background with particular reference to corporate governance, financial reporting, and ownership structure. Section 3.2 discusses the institutional reforms implemented following the 1997 financial crisis. The reforms in financial reporting in Malaysia, especially following the introduction of the Financial Reporting Act (1997) are outlined in Section 3.3. Section 3.4 explains the ownership structure of Malaysian firms, with particular emphasis on family firms and state-controlled firms. Finally, Section 3.5 summarizes the chapter.

\subsection{The 1997 Asian Economic Crisis and Reforms in Corporate Governance}

\subsubsection{Before the Crisis}

Attention to corporate governance emerged in Malaysia with the introduction of the Companies Act 1965 and was subject to progressive development long before the 1997 economic crisis. The 1965 Act describes the roles and responsibilities of directors and managers to keep proper accounting records (Abdullah \& Mohd Nasir, 2004). Subsequently, the Securities Industries Act (SIA) 1983 and the Securities Commission Act (SCA) 1993 provided a legislative and regulatory framework for the Malaysian capital market. These last two Acts prohibited 
artificial trading and market rigging, thereby effectively regulating the operations of securities dealers (Liew, 2007).

The Securities Commission was established in March 1993 as a watchdog to improve the legal and regulatory framework governing the capital market. In the same year, the Bursa Malaysia Listing Requirements were revised to require all listed firms to set up audit committees of at least three people, comprising a majority of independent directors. This requirement was intended to improve the standards of corporate disclosure in Malaysia (Wan Hussin \& Ibrahim, 2003).

To enhance the accountability of directors and to promote good corporate ethics, the Companies Commission of Malaysia, formerly known as the Registrar of Companies, introduced the Code of Ethics for Directors in 1996. In the same year, the Securities Commission moved from a merit-based system to disclosure-based regulation, which ensured high-quality financial reporting by promoting improved standards of disclosure, due diligence, corporate governance and accountability among the directors of public firms. Under the new system, the role of the Securities Commission shifted from evaluating the relative merits of the issuer and its securities to regulating the disclosure of quality information (Che Haat, 2006). ${ }^{4}$ The final implementation phase of disclosure-based regulation would require all listed firms, among other requirements, to: (1) publish financial

\footnotetext{
${ }^{4}$ Disclosure-based regulation (DBR) was implemented in three phases: Phase 1 (1996-1999) focuses on a flexible/hybrid merit-based regime which emphasises disclosure, due diligence and corporate governance; Phase 2 (1999-2000) moves to partial DBR which emphasises disclosure, due diligence and corporate governance, and the promotion of accountability and self-regulation; and Phase 3 (2001onwards), full DBR, was implemented emphasizing high standards of disclosure, due diligence and corporate governance as well as the promotion of self-regulation and responsible conduct.
} 
statements on a quarterly basis within two months of each financial quarter (these statements included an income statement, a balance sheet, a cash flow statement and explanatory notes); (2) furnish annual audited accounts, and auditors' and directors' reports within four months from the end of the financial year; and (3) make immediate public disclosure of all material information of a financial and non-financial nature concerning its affairs (Nathan, Lin, \& Fong, 2000).

\subsubsection{The Crisis}

The Asian economic crisis began in July 1997. The value of the Malaysian currency, Ringgit Malaysia (MYR), dropped from MYR 2.50 per US\$ to, at one point, MYR 4.80 per US\$. The Bursa Malaysia composite index fell from approximately 1300 to nearly 400 points in a few short weeks. Interest rates increased to more than $12 \%$ during the crisis. These problems started with the speculative short-selling of Malaysian currency, which was followed by high capital outflows from the country (Abdul Rahman, 2006). In December 1997, to control these problems, the Malaysian government imposed capital controls including pegging the Malaysian Ringgit at 3.80 to the US dollar. Other measures included restricting the trading of Malaysian stocks outside Malaysia, introducing a punitive tax for holding Malaysian stocks for less than one year and making unofficial trading of the ringgit illegal (Poon, 2000).

The origins of the economic crisis are a matter of debate. Prime Minister Dr Mahathir accused currency speculator, George Soros, of causing the problem. Many economists, however, would argue the will of the country to overcome the crisis had been weakened by endemic structural and policy weaknesses (Fischer, 
1998; Kawai, Newfarmer, \& Schmukler, 2001; Miller \& Luangaram, 1998; UNCSD, 2002; Zhuang, 1999). Among the alleged weaknesses were inappropriate exchange rate policies, poor corporate governance and transparency, inadequate prudential banking supervision, excessive short-term unhedged corporate foreign debt, and corporate moral hazard problems due to implicit government guarantees for risky debt-financed investments (Morris, Pham, \& Gray, 2011).

The financial crisis also caused a massive loss of foreign investors' confidence in the Malaysian capital market (Abdul Rahman \& Haniffa, 2005), and this was exacerbated by poor corporate governance. Rajan and Zingales (1998) argue that investors ignored weaknesses in East Asian firms when the economy was doing well, but quickly pulled out once the crisis began because they believed the region lacked adequate institutional protection for their investments. Further, expropriation of minority shareholders became worse during that period. In addition, Johnson, Boone, Breach, and Friedman (2000) argue that in countries with weak corporate governance, the financial crisis resulted in more expropriation of wealth by managers and thus caused a larger fall in asset prices.

United Engineers Malaysia (UEM), a blue chip firm in Malaysia, provides an example of the expropriation of minority shareholders interests during the financial crisis. In November 1997, UEM acquired $32.6 \%$ of Renong, its financially troubled parent. The minority shareholders were horrified and saw this transaction as a bailout of Renong at an inflated price. UEM's stock price fell $38.24 \%$ on the day the transaction was announced (Foon, 1997, November 19, p. 
62). The controversy surrounding this transaction, which was undertaken without proper disclosure and prior shareholder approval, led to a significant loss in investors' confidence in the Malaysian stock market (Abdul Rahman, 2006).

The impact of the financial crisis, in particular reduced investor confidence in the Malaysian capital market, provided a strong impetus for regulators to introduce reforms to enhance the protection of investors. The reforms targeted two main areas: corporate governance and financial reporting. La Porta, Lopez-de-Silanes, Shleifer, and Vishny $(2000 ; 1998)$ contend that corporate governance is an important factor in financial market development and firm value. Johnson et al. (2000), for instance, show that country-specific measures of corporate governance explain the extent of currency depreciation and stock market decline in emerging markets during the crisis better than standard macroeconomic variables. In response to the demand for a stronger capital market, regulators adopted various strategies. These are discussed in the remainder of this section. Matters relating to financial reporting reforms are discussed separately in Section 3.3.

Corporate governance reforms, among others, are crucial to: (1) strengthening the protection of minority shareholders' rights; (2) enhancing the transparency and accountability of directors; (3) strengthening regulatory enforcement; and (4) promoting training and education at all levels in corporations (Finance Committee on Corporate Governance, 1999).

The reforms started with the establishment of the High Level Finance Committee on Corporate Governance by the Ministry of Finance in March 1998, followed by 
a series of regulatory changes through the Securities Commission, Bursa Malaysia, and the Companies Commission of Malaysia. This included the establishment of the Malaysian Institute of Corporate Governance, and the Minority Shareholder Watchdog Committee. Table 3.1 summarises the corporate governance and financial reporting initiatives and reforms made by Malaysian authorities after the economic crisis.

\section{Table 3.1}

Corporate governance initiatives and reforms (1997-2002)

\begin{tabular}{|l|l|}
\hline Year & \multicolumn{1}{|c|}{ Initiatives and Reforms } \\
\hline 1997 & An independent accounting standard-setting board was introduced. \\
\hline 1998 & $\begin{array}{l}\text { The formation of the High Level Finance Committee to conduct a detailed study on } \\
\text { corporate governance and to make recommendations for improvements. }\end{array}$ \\
\hline 1998 & $\begin{array}{l}\text { Amendments were made to the Securities Industry Central Depository Act (SICDA) } \\
\text { with a view to enhancing transparency in share ownership amidst other improvements. }\end{array}$ \\
\hline 1998 & The Malaysian Institute of Corporate Governance was established. \\
\hline 1998 & $\begin{array}{l}\text { Regulations for directors and CEOs to disclose interest in the publicly listed companies } \\
\text { PLC) were introduced. }\end{array}$ \\
\hline 1999 & Quarterly reporting was introduced. \\
\hline 1999 & A revamp of the takeovers and mergers code was done. \\
\hline 2000 & The Malaysian Code on Corporate Governance was introduced. \\
\hline 2000 & $\begin{array}{l}\text { Amendments were made to the Securities Commission Act 1993 by making the } \\
\text { Securities Commission the sole regulator for fund-raising activities and the corporate } \\
\text { bond market. }\end{array}$ \\
\hline 2001 & The Audit Committee must have a member who is financially trained. \\
\hline 2001 & $\begin{array}{l}\text { The Malaysian Capital Market master plan was launched to further streamline and } \\
\text { regulate the capital market and to chart the course for the capital market for the next } \\
\text { ten years. }\end{array}$ \\
\hline 2001 & $\begin{array}{l}\text { The Financial Sector master plan was launched to chart the future direction of the } \\
\text { financial system over the next ten years. It outlined strategies to achieve a diversified, } \\
\text { effective, efficient and resilient financial system. }\end{array}$ \\
\hline 2001 & The mandatory disclosure of corporate governance code compliance was introduced. \\
\hline 2001 & A minority shareholders watchdog group was established. \\
\hline 2002 & A mandatory accreditation programme for directors was introduced. \\
\hline
\end{tabular}

Source: Mahmood, (2003); Securities Commission of Malaysia (www.sc.com.my/index.asp; accessed on 02.01.09); Malaysian Institute of Corporate Governance (www.micg.net/home.htm; accessed on 02.01.09)

The High Level Finance Committee on Corporate Governance, comprising government and industry representatives, carried out detailed investigations to identify and address weaknesses relating to the 1997 financial crisis. Bursa Malaysia and PriceWaterhouseCoopers (PWC), on the other hand, conducted a 
survey on corporate governance of public listed firms and then made recommendations for corporate governance best practices for Malaysia (Ow-Yong \& Kooi Guan, 2000). The result was the Report on Corporate Governance, 1999, which highlighted the importance of boards of directors as corporate governance mechanisms to protect and enhance shareholder wealth. The report aimed to improve corporate disclosure, promote good corporate governance practice in Malaysia, and to re-establish investor confidence in the Malaysian capital market (Finance Committee on Corporate Governance, 1999).

Following the recommendations proposed by the Finance Committee on Corporate Governance (FCCG), the High Level Finance Committee on Corporate Governance introduced the Malaysian Code on Corporate Governance (MCCG) in March 2000. This code which was heavily influenced by the Cadbury Report and the Hampel Report in the United Kingdom (Finance Committee on Corporate Governance, 2000), empowered investors by providing them with information on listed firms' corporate governance practices. In addition to the audit committee, which had been mandatory since 1993, the MCCG recommended the board of directors appoint remuneration and nomination committees. Other committees, such as a risk management committee and corporate governance committee were also recommended (Finance Committee on Corporate Governance, 2000). The MCCG also recommended separation of roles between chief executive officer and chairman of the board of directors, though this was not required by the Listing Requirements of Bursa Malaysia.

Another important aspect of corporate governance is the firm's internal control 
system. The MCCG stressed that the board of directors should maintain a sound system of internal control. The Guide for Statement of Internal Control, 2000, noted various key areas that directors must pay attention to before they include the Statement of Internal Control in the annual reports. In reporting the corporate governance principles and best practices in annual corporate reports, all listed firms are required to provide information pertaining to internal control such as identifying principal risks and ensuring implementation of appropriate systems to manage risks.

In January 2001, the MCCG came into full effect when an amendment was made to the Listing Requirements of the Bursa Malaysia. It is important to note that the MCCG is not mandatory for all listed firms, but the revision of the listing requirements creates strong demand for higher standards of conduct and a higher quality of financial reporting by public listed firms. The revision, for example, requires all public listed firms to include in their annual report a statement of corporate governance, a statement of internal control, the composition of the board of directors, the composition of and quorum for the audit committee (Kuala Lumpur Stock Exchange, 2001). Under the revamped listing requirements, all listed firms must include in their annual reports a narrative of the application of the principles and best practices set out in the MCCG. Reasons for areas of noncompliance and alternative practices that were adopted must be justified and disclosed. In addition, directors of publicly listed firms are required to attend a directors' training program, known as the mandatory accreditation programme, which includes topics such as the Companies Act 1965, the Listing Requirements of Bursa Malaysia, risk management and internal control, and relevant securities 
laws.

In March 1998, the Malaysian Institute of Corporate Governance (MICG) was established by the High Level Finance Committee on Corporate Governance, with the objective, amongst others, of facilitating the development of corporate governance and strengthening corporate governance principles and compliance efforts. The MICG is a non-profit public firm limited by guarantee, with founding members from various bodies, including the Federation of Public Listed Companies (FPLC), the Malaysian Institute of Accountants (MIA), the Malaysian Association of Certified Public Accountants (MICPA), the Malaysian Institute of Chartered Secretaries and Administrators (MAICSA), and the Malaysian Institute of Directors (MID). The MICG seeks to provide an independent platform for various stakeholders to interact and debate corporate governance issues, in which it promotes continuous improvement in corporate governance best practices.

Following a recommendation in the Report on Corporate Governance, the Minority Shareholder Watchdog Group (MSWG) was established in August 2000. The MSWG is a special governing body set up as a 'check and balance' mechanism to protect the interests of minority shareholders from being abused by the majority shareholders. The establishment of the MSWG is one strategy to enhance corporate governance and encourage independent and proactive shareholder participation in the listed firms. The MSWG comprises representatives from the five largest institutional funds in the country, including the Employee Provident Fund (EPF), Permodalan Nasional Berhad (PNB), Social Security Organization (SOCSO), Lembaga Tabung Haji (LTH), and Lembaga 
Tabung Angkatan Tentera (LTAT) (Abdul Wahab, How, \& Verhoeven, 2007).

In February 2001, the Securities Commission launched the Capital Market Master Plan (CMP) in response to the recommendations contained in the Report on Corporate Governance. The CMP contains 152 recommendations, of which 10 deal with development of the institutional and regulatory framework for the capital market from 2001 to 2010 . The focus is mainly on corporate governance issues. Later, in August 2003, the Corporate Law Reform Committee was established to spearhead the corporate law reform programme. This was perceived as another milestone for corporate governance reforms in Malaysia.

Legal provision for whistle blowers was another aspect highlighted in the Report on Corporate Governance prepared by the Finance Committee. To address this matter, the Securities Industry Act 1983 (SIA) was amended by Parliament in September 2003 with effect from 5 January 2004. The SIA introduces provisions governing whistle blowers and enhances enforcement/investor redress mechanisms for breaches of securities laws. This amendment is crucial because it ensures that auditors can disclose information that is material to the regulators, and also deals with internal whistle blowers, usually the key officers dealing with the financial statements of the company.

The efforts to improve corporate governance and protect investors and shareholders continued even after the issuance of the MCCG. Various initiatives to strengthen the existing mechanism were undertaken, including the issuance of the guideline Best Practice in Corporate Disclosure by Bursa Malaysia in August 
2004. The objective of the guideline is to ensure compliance of public listed firms with disclosure obligations under the Listing Requirements and securities law. More importantly, the Best Practice guide is intended to inspire trust and confidence between investors and public listed firms by ensuring firms provide equal access to information in a timely, accurate, and complete manner.

In October 2007, the MCCG was revised to strengthen the roles and responsibilities of boards of directors and audit committees. The revision provides guidelines for the appointment of directors, the role of nominating committees, the eligibility criteria for appointment as an audit committee member, the audit committee composition, the frequency of meetings and the need for continuous training. The 2007 Revised MCCG Code requires the audit committee to consist of at least three members (all of whom must be non-executive directors), and a majority of whom must be independent directors. Further, it is recommended that all audit committee members should be financially literate, with at least one member being a member of an accounting association or body. The Revised Code also enhances the role of the nomination committee by requesting that when candidates are recommended for directorships they should have the necessary skills, knowledge, expertise, experience, professionalism, and integrity to strengthen the board and to ensure the board discharges its roles and responsibilities effectively. The Revised Code also provides greater clarity to the board's roles in regard to compensation, monitoring, and replacement of management, and planning the succession of senior management. 


\subsection{Financial Reporting Reforms and Adoption of IFRS}

The introduction of the Financial Reporting Act 1997 (Act 558) (FRA 1997) was the most important development in financial reporting in Malaysia. The Act, which was gazetted on 6 March 1997, introduced and set out the first formal accounting framework for Malaysia in response to the rapid economic development and globalization of the commercial market that demanded a higher quality of financial reporting and accounting practices (Fadzly \& Ahmad, 2004). Two bodies, the Malaysian Accounting Standards Board (MASB) and the Financial Reporting Foundation (FRF), were established under FRA 1997. MASB issued accounting standards for both public and private firms. This made Malaysia the first country in the Southeast Asia region to give legal status to accounting standards. At the same time, the FRA 1997 ended the long conflict between the Malaysia Institute of Accountants (MIA) and the Malaysian Institute of Certified Public Accountants (MICPA) on standards setting.

The development of accounting standards in Malaysia began in the early 1970s. At the time, MICPA played the main role despite the existence of MIA which governed the accounting profession in the country. Standard setting in Malaysia began when the MICPA President received a letter from the governor of the Malaysian Central Bank ${ }^{6}$ highlighting the need for professional standards to guide financial reporting in Malaysia (Selvaraj, 1999). The letter also requested the

\footnotetext{
${ }^{5}$ FRF is a trustee body which is responsible for overseeing the MASB's performance, financial and funding arrangements. It acts as a sounding board for the MASB, insofar as the FRF is the first to review MASB's technical pronouncements before it goes out to the public.

${ }^{6}$ Also known as Bank Negara Malaysia
} 
MICPA to provide a statement of generally accepted accounting principles for its members (Selvaraj, 1999). In response to the letter, the MICPA set up a Technical Committee to review matters raised by the Central Bank. After 1976, the committee started to assess the International Accounting Standards (IAS) for local adoption and to conduct studies on accounting standards relating to industries of particular importance to the Malaysian economy (Selvaraj, 1999). Eventually, Malaysia selectively adopted the International Accounting Standards (IAS) in 1978.

From 1987 until 1992, both professional bodies, the MIA and the MICPA, had jointly developed accounting standards, especially on local issues. Examples of accounting standards developed from this collaboration are MAS 1 on Earnings Per Share, MAS 2 on Mergers and Acquisitions, and MAS 5 on Accounting for Aquaculture. However, the professional bodies failed to reach agreement on MAS 6 on Goodwill, which then led to conflict and the dissolution of their collaboration. In this conflict, the MIA issued an exposure draft for MAS $6^{7}$, which was based on the controversial UK ED 47. The MICPA, however, decided that adoption of MAS 6 should be deferred until the controversy surrounding the UK's ED 47 was determined or until the International Accounting Standards Committee (IASC) issued a revised standard on goodwill. According to Selvaraj (1999), the disagreement over MAS 6 triggered the dissolution of the Common Working Technical Committee and ended the MIA-MICPA collaboration. The two professional bodies then continues to develop separate accounting standards

\footnotetext{
${ }^{7}$ MAS requires goodwill to be amortised over 25 years
} 
(Selvaraj, 1999). This created confusion among accounting practitioners and distorted the development of accounting standards in Malaysia.

By 1997, in addition to eight customised Malaysian Accounting Standards (MAS), twenty-four International Accounting Standards (IAS) had been adopted in Malaysia. The IAS had become the model for Malaysian accounting standards, for several reasons. First, the early accounting professionals in Malaysia were trained overseas, particularly in the United Kingdom and Australia, thus, they gained a certain respect for the international accounting system. Second, the cost of adopting an existing set of accounting standards was lower than developing the standards from scratch. Adoption of international accounting standards requires less time and effort, and allows the local accounting profession to have a structured and strong set of accounting standards. Third, adoption of the IAS is also a strategy to gain international recognition. It would also ensure that financial statements produced by Malaysian companies were comparable and reliable.

Even though the MIA and the MICPA both adopted IAS standards and issued local accounting standards, there was no regulatory body nor any statutory requirement to enforce compliance with accounting standards in Malaysia prior to the introduction of FRA 1997 (Saleh, Iskandar, \& Rahmat, 2005). As a result, there were varying degrees of compliance with accounting standards among the Malaysian public listed firms. This scenario suggests a weak financial reporting environment in Malaysia compared to that in the United Kingdom and the United States. The empirical evidence from Ball et al. (2003) supports this notion. Ball et al. (2003) find low earnings quality in Malaysian financial reporting during the 
period 1984 to 1996 , which was attributed to the weak institutional foundation and legal environment.

From 1997, the standards-setting roles no longer rested with the professional bodies. Under FRA 1997, the Malaysian Accounting Standards Board (MASB), together with the Financial Reporting Foundation (FRF), became the only standard-setting bodies. Standard-setting became more independent and more representative. It had representatives from all relevant parties including preparers, users, regulators, and the accounting profession. Section 7 of the FRA 1997, states the functions of the MASB as follows:

...(a) to issue new accounting standards as approved accounting standards; (b) to review, revise or adopt existing accounting standards as approved accounting standards; (ba) to amend, substitute for, suspend, defer, withdraw or revoke any approved accounting standards in whole or in part; (c) to issue statements of principles for financial reporting; (d) to sponsor or undertake development of possible accounting standards; (e) to conduct such public consultation as may be necessary in order to determine the contents of accounting concepts, principles and standards; (f) to develop a conceptual framework for the purpose of evaluating proposed accounting standards; (g) to make such changes to the form and content of proposed accounting standards as it considers necessary; and (h) to perform such other function as the Minister may prescribe by order published in the Gazette. (p. 9-10)

With the power provided under the Act, the MASB has reviewed, revised and adopted existing accounting standards and issued new standards as approved accounting standards, known collectively as MASB standards. By the end of 2003, the Board had 32 approved accounting standards for publicly listed companies in Malaysia, including 28 standards adopted from the International Accounting Standards and 4 locally developed standards, as shown in Table 3.2. 
Table 3.2

List of MASB Standards as at 31 December 2003

Panel A: MASB's standards adopted from the International Accounting Standards

\begin{tabular}{|c|c|c|c|}
\hline MASB & Title (as in MASB standards) & IAS & Effective Date \\
\hline MASB 1 & Presentation of Financial Statements & IAS 1 & 1 July 1999 \\
\hline MASB 2 & Inventories & IAS 2 & 1 July 1999 \\
\hline MASB 3 & $\begin{array}{l}\text { Net Profit or Loss for the Period, Fundamental } \\
\text { Errors and Changes in Accounting Policies }\end{array}$ & IAS 8 & 1 July 1999 \\
\hline MASB 4 & Research and Development Costs & IAS 9 & 1 July 1999 \\
\hline MASB 5 & Cash Flow Statement & IAS 7 & 1 July 1999 \\
\hline MASB 6 & Effects of Changes on Foreign Exchange Rates & IAS 21 & 1 July 1999 \\
\hline MASB 7 & Construction Contracts & IAS 11 & 1 July 1999 \\
\hline MASB 8 & Related Parties & IAS 24 & 1 January 2000 \\
\hline MASB 9 & Revenue & IAS 18 & 1 January 2000 \\
\hline MASB 10 & Leases & IAS 17 & 1 January 2000 \\
\hline MASB 11 & $\begin{array}{l}\text { Consolidated Financial Statements and Investments } \\
\text { in Subsidiaries }\end{array}$ & IAS 27 & 1 January 2000 \\
\hline MASB 12 & Investment in Associates & IAS 28 & 1 January 2000 \\
\hline MASB 13 & Earnings per Share & IAS 33 & 1 January 2000 \\
\hline MASB 14 & Depreciation Accounting & IAS 4 & 1 July 2000 \\
\hline MASB 15 & Plant, Property and Equipment & IAS 16 & 1 July 2000 \\
\hline MASB 16 & Financial Reporting of Interest in Joint Ventures & IAS 31 & 1 July 2000 \\
\hline MASB 19 & Events After the Balance Sheet Date & IAS 10 & 1 July 2001 \\
\hline MASB 20 & $\begin{array}{l}\text { Provisions, Contingent Liabilities and Contingent } \\
\text { Assets }\end{array}$ & IAS 37 & 1 July 2001 \\
\hline MASB 21 & Business Combinations & IAS 22 & 1 July 2001 \\
\hline MASB 22 & Segment Reporting & IAS 14 & 1 January 2002 \\
\hline MASB 23 & Impairment of Assets & IAS 36 & 1 January 2002 \\
\hline MASB 24 & Financial Instruments: Disclosure and Presentations & IAS 32 & 1 January 2002 \\
\hline MASB 25 & Income Taxes & IAS 12 & 1 July 2002 \\
\hline MASB 26 & Interim Financial Reporting & IAS 34 & 1 July 2002 \\
\hline MASB 27 & Borrowing Costs & IAS 23 & 1 July 2002 \\
\hline MASB 28 & Discontinuing Operations & IAS 35 & 1 January 2003 \\
\hline MASB 29 & Employee Benefits & IAS 19 & 1 July 2003 \\
\hline MASB 30 & $\begin{array}{l}\text { Accounting and Reporting by Retirement Benefits } \\
\text { Plans }\end{array}$ & IAS 26 & 1 July 2003 \\
\hline
\end{tabular}

Panel B: MASB's locally developed accounting standards

\begin{tabular}{llll}
\hline $\begin{array}{l}\text { Previously } \\
\text { known as }\end{array}$ & MASB & Title (as in MASB standards) & Effective Date \\
\hline MAS 3 & MASB 17 & General Insurance Business & 1 July 2000 \\
MAS 4 & MASB 18 & Life Insurance Business & 1 July 2000 \\
MAS 5 & MAS 5 & Accounting for Aquaculture & 1 September 1998 \\
& MASBi-1 & $\begin{array}{l}\text { Presentation of Financial Statements of } \\
\text { Islamic Financial Reporting }\end{array}$ & 1 January 2003 \\
\hline
\end{tabular}

Source: Malaysian Accounting Standards Board 
In 1998, a year after the Financial Reporting Act was enacted by the Parliament, the Companies Act 1965 was also amended to include a new provision ${ }^{8}$, which requires companies to comply with the 'approved accounting standards' as defined in Section 2 of FRA 1997. This amendment creates legally binding accounting standards, and thus requires compliance with the accounting standards issued by the MASB. To enforce the compliance of MASB standards, a number of regulatory bodies, including the Securities Commission, Bursa Malaysia (formerly known as the Kuala Lumpur Stock Exchange), the Central Bank of Malaysia, and the Companies Commission of Malaysia, are responsible within their respective jurisdictions for ensuring compliance. In the event of non-compliance, the regulators have the power to direct the company to take the necessary rectifying actions, or make necessary announcements with respect to the non-compliance or required corrections. They also have powers to impose penalties for such offences committed by public listed firms.

The Securities Commission (SC) enforces several aspects of compliance with the accounting standards for publicly listed companies through the issuance of its rules and policies. For example, the SC requires all listed firms to meet the terms in its Corporate Disclosure Policy, which demands firms maintain a high level of disclosure. The SC also issued Post Listing Obligations, requiring all submitted annual and interim corporate reports to be prepared in accordance with approved accounting standards. In addition, the SC frequently discusses and reviews issues relating to the minimum compliance with accounting standards and other statutory

\footnotetext{
${ }^{8}$ Section 166A of Companies Act 1965 [Act 125]
} 
requirements for publicly listed firms in Malaysia. The SC also requires companies that seek to issue or offer securities to the public to submit the proposed issuance to the SC for approval. Companies that fail to submit the proposal, or that submit false and misleading information to the SC, may incur a fine of RM3 million or, in the case of directors of such companies, 10 years imprisonment.

Bursa Malaysia also enforces the application of approved accounting standards among Malaysian listed firms. For listed firms, compliance with the accounting standards is made mandatory through the Bursa Malaysia listing requirements. The listing requirements require submission of corporate annual reports and the preparation of financial statements must be in accordance with approved accounting standards. Firms that fail to meet this requirement may, among other things, receive letters of caution, receive reprimands, be fined an amount not exceeding RM1 million, be given directions for rectification, face the nonacceptance of applications or submissions, have conditions imposed for approval of submissions, face suspension of trading, and may be delisted by Bursa Malaysia. In the case of a breach of the listing requirements, Bursa Malaysia may also on application to the High Court, seek an order requiring a particular director to be removed from the firm's board and barred from holding directorship in any other listed firm.

The Companies Commission of Malaysia (CCM) is a government agency that is responsible for regulating matters relating to the incorporation of companies and business registration. In addition, CCM promotes good ethical conduct amongst 
directors and managers. In terms of financial reporting, CCM is concerned with compliance with accounting standards in the financial statements of private companies. Yet, another agency, the Central Bank of Malaysia, deals with matters relating to banks and financial institutions. Besides ensuring that financial statements of banks and financial institutions comply with approved accounting standards, the Central Bank also provides specimen financial statements and guidelines on financial reporting for banks and financial institutions that deal specifically with non-performing loans and interest.

A further development in financial reporting occurred in 2005. In that year, all listed firms in the European Union started to prepare financial statements using the International Financial Reporting Standards (IFRS). Other countries around the world quickly followed suit. Malaysia adopted IFRS from 1 January 2006. In October 2005 the MASB published a notice of issuance of 18 of the 21 new/revised MASB-approved accounting standards for application in relation to financial statements, including 11 Issues Committee Interpretations. These pronouncements were to be effective for financial periods beginning on or after 1 January 2006. In 2005, MASB standards were renamed to Financial Reporting Standards (FRS), in line with International Financial Reporting Standards (IFRS). In addition, MASB also changed the numbering of the standards to correspond to those of the relevant international standards. This move eliminated an anomaly whereby the numbering of MASB standards differed from their respective international standards. Table 3.3 shows the changes made to MASB standards in the process of IFRS adoption. 
Table 3.3

Change of name of MASB standards on January 1, 2005

\begin{tabular}{|c|c|c|c|}
\hline Standard & New name & Title & Effective Date \\
\hline MASB 1 & FRS $101_{2004}$ & Presentation of Financial Statements & 1 July 1999 \\
\hline MASB 2 & FRS $102_{2004}$ & Inventories & 1 July 1999 \\
\hline MASB 3 & FRS $108_{2004}$ & $\begin{array}{l}\text { Net Profit or Loss for the Period, } \\
\text { Fundamental Errors and Changes in } \\
\text { Accounting Policies }\end{array}$ & 1 July 1999 \\
\hline MASB 4 & FRS $109_{2004}$ & Research and Development Costs & 1 July 1999 \\
\hline MASB 5 & FRS $107_{2004}$ & Cash Flow Statements & 1 July 1999 \\
\hline MASB 6 & FRS $121_{2004}$ & $\begin{array}{l}\text { The Effects of Changes in Foreign } \\
\text { Exchange Rates }\end{array}$ & 1 July 1999 \\
\hline MASB 7 & FRS $111_{2004}$ & Construction Contracts & 1 July 1999 \\
\hline MASB 8 & FRS $124_{2004}$ & Related Party Disclosures & 1 January 2000 \\
\hline MASB 9 & FRS $118_{2004}$ & Revenue & 1 January 2000 \\
\hline MASB 10 & FRS $117_{2004}$ & Leases & 1 January 2000 \\
\hline MASB 11 & FRS $127_{2004}$ & $\begin{array}{l}\text { Consolidated Financial Statements and } \\
\text { Investments in Subsidiaries }\end{array}$ & 1 January 2000 \\
\hline MASB 12 & FRS $128_{2004}$ & Investments in Associates & 1 January 2000 \\
\hline MASB 13 & FRS $133_{2004}$ & Earnings Per Share & 1 January 2000 \\
\hline MASB 14 & FRS $104_{2004}$ & Depreciation Accounting & 1 July 1999 \\
\hline MASB 15 & FRS $116_{2004}$ & Property, Plant and Equipment & 1 July 2000 \\
\hline MASB 16 & FRS $131_{2004}$ & $\begin{array}{l}\text { Financial Reporting of Interest on Joint } \\
\text { Ventures }\end{array}$ & 1 July 2000 \\
\hline MASB 17 & FRS 202 2004 & General Insurance Business & 1 July 2001 \\
\hline MASB 18 & FRS $230_{2004}$ & Life Insurance Business & 1 July 2001 \\
\hline MASB 19 & FRS $110_{2004}$ & Events After the Balance Sheet Date & 1 July 2001 \\
\hline MASB 20 & FRS $137_{2004}$ & $\begin{array}{l}\text { Provision, Contingent Liabilities and } \\
\text { Contingent Assets }\end{array}$ & 1 July 2001 \\
\hline MASB 21 & FRS $122_{2004}$ & Business Combinations & 1 July 2001 \\
\hline MASB 22 & FRS $114_{2004}$ & Segment Reporting & 1 January 2002 \\
\hline MASB 23 & FRS $136_{2004}$ & Impairment of Assets & 1 January 2002 \\
\hline MASB 24 & FRS 1322004 & $\begin{array}{l}\text { Financial Instruments: Disclosure and } \\
\text { Presentations }\end{array}$ & 1 January 2002 \\
\hline MASB 25 & FRS $112_{2004}$ & Income Taxes & 1 July 2002 \\
\hline MASB 26 & FRS $134_{2004}$ & Interim Financial Reporting & 1 July 2002 \\
\hline MASB 27 & FRS $123_{2004}$ & Borrowing Costs & 1 July 2002 \\
\hline MASB 28 & FRS $135_{2004}$ & Discontinuing Operations & 1 January 2003 \\
\hline MASB 29 & FRS $119_{2004}$ & Employee Benefits & 1 January 2003 \\
\hline MASB 30 & FRS $126_{2004}$ & $\begin{array}{l}\text { Accounting and Reporting } \\
\text { Retirement Benefit Plans }\end{array}$ & 1 January 2003 \\
\hline MASB 31 & FRS $120_{2004}$ & $\begin{array}{l}\text { Accounting for Government Grants and } \\
\text { Disclosures of Government Assistance }\end{array}$ & 1 January 2004 \\
\hline MASB $i-1$ & FRS $i-1_{2004}$ & $\begin{array}{l}\text { Presentation of Financial Statements of } \\
\text { Islamic Financial Institutions }\end{array}$ & 1 January 2003 \\
\hline
\end{tabular}

Source: Malaysian Accounting Standards Board

It is important to note that the change of name from MASB standards to FRS in 2005 did not actually change the content of the standard. The real adoption of IFRS was made effective starting from January 1, 2006. There are a number of significant changes to the country's accounting standards as a result of the 
adoption of IFRS, as summarised in Appendix 2. Although standards are named as FRS, as at January 2006 Malaysian FRS are almost word-for-word identical to the corresponding IFRS issued by the IASB, except for some standards that have not yet as at 31 December 2008 been made effective, namely IFRS 7 Financial Instruments: Disclosures and IFRS 8 Operating Segments.

The Financial Reporting Standards (FRS) also include one Islamic accounting standard and four local standards, which deal with matters that are not covered under IFRS or IAS. ${ }^{9}$ These standards have been developed particularly to cater for the Malaysian environment. The local standards are FRS 201 2004 Property Development Activities, FRS 202 2004 General Insurance Business, FRS 2032004 Life Insurance Business, FRS 204 2004 Accounting for Aquaculture. According to the Financial Reporting Act 1997, compliance with these FRS is mandatory. As stated in Section 26D of the Act:

Where financial statements are required to be prepared or lodged under any law administered by the Securities Commission, the Central Bank or the Registrar of Companies, such financial statements shall be deemed not to have complied with the requirements of such law unless they have prepared and are kept in accordance with the approved accounting standards. (p. 18)

Malaysian Accounting Standards Board (MASB) adopted IFRS and made the standards effective from 1 January 2006. Therefore, the earliest financial statements reported by Malaysian companies under the mandated IFRS are dated 31 December 2006. Taking into account the adoption of IFRS, the MASB has

\footnotetext{
${ }^{9}$ FRS i- $1_{2004}$ Presentation of Financial Statements of Islamic Financial Institutions.
} 
currently produced a total of 208 technical pronouncements, comprising 85 Standards (including interpretations), 2 Forewords, 1 Framework, 2 SOPs, 5 Technical Releases, 19 Translations and 94 Exposure Drafts for both private and non-private entities. Appendix 2 summarises the principal differences between IFRS and MASB that have had a significant impact on financial reports after the adoption of IFRS ${ }^{10}$.

Table 3.4

IFRS adoption in Malaysia as at 31 December 2008

\begin{tabular}{|c|c|c|c|}
\hline Standard & Title & Effective Date & Status \\
\hline IFRS 1 & $\begin{array}{l}\text { First-time Adoption of FRS Reporting } \\
\text { Standards }\end{array}$ & 1 January 2006 & Enacted \\
\hline IFRS 2 & Share-based Payment & 1 January 2006 & Enacted \\
\hline IFRS 3 & Business Combinations & 1 January 2006 & Enacted \\
\hline IFRS 4 & Insurance Contracts & - & $\begin{array}{l}\text { Exposure Draft } \\
\text { issued }\end{array}$ \\
\hline IFRS 5 & $\begin{array}{l}\text { Non-current Assets Held for Sale and } \\
\text { Discontinued Operations }\end{array}$ & 1 January 2006 & Enacted \\
\hline IFRS 6 & $\begin{array}{l}\text { Exploration for and Evaluation of Mineral } \\
\text { Resources }\end{array}$ & 1 January 2007 & Enacted \\
\hline IFRS 7 & Financial Instruments: Disclosures & - & $\begin{array}{l}\text { Exposure Draft } \\
\text { issued }\end{array}$ \\
\hline IFRS 8 & Operating Segments & - & $\begin{array}{l}\text { Exposure Draft } \\
\text { issued }\end{array}$ \\
\hline
\end{tabular}

Note: The numbering of the FRSs corresponds to the IFRSs issued by the IASB. For example, FRS 1 in Malaysia is equivalent to IFRS 1 . FRS with a ' 100 prefix' corresponds to its equivalent IASs. Thus FRS 101 is equivalent to IAS 1 . FRS with a ' 200 prefix' denotes locally developed Standard with no equivalent International Standard.

As reported in Table 3.4, FRS 4, FRS 7 and FRS 8 have still not been adopted by the MASB. The full merging with the International Financial Reporting Standards is scheduled for 1 January 2012.

In short, the financial reporting framework in Malaysia has experienced

\footnotetext{
${ }^{10}$ The purpose of the table is to highlight the main changes in accounting standards after the adoption of IFRS. It is highly summarized and does not provide complete requirements of the standards.
} 
significant changes since 1997. The introduction of FRA 1997 led to the establishment of the MASB, which resolved long-standing conflicts between the MIA and MICPA. Since its establishment, the MASB has played a vital role in setting accounting standards, including adoption of IAS standards and the introduction of local standards. Another very important event in the development of financial reporting in Malaysia is the adoption of IFRS starting from 1 January 2006.

\subsection{Ownership Structure of Malaysian Firms}

Dispersed ownership is common in most developed countries, such as the United States and the United Kingdom, but in Malaysia firms are insider-dominated with highly-concentrated shareholdings. World Bank (1999), based on a study conducted in 1998 of Malaysian firms, shows that the five largest shareholders of the firms in the sample owned $60.4 \%$ of the outstanding shares and more than half of the voting shares. Some $67.2 \%$ of shares were in family hands, $37.4 \%$ had only one dominant shareholder and $13.4 \%$ were state-controlled. A similar finding was reported by Capulong, Edwards, Webb, and Zhuang (2001), where the largest shareholder still possessed an average $30.3 \%$ of outstanding shares among all listed firms in Malaysia in 1998, with the top five shareholders owning an average $58.8 \%$

The highly-concentrated shareholdings have evolved historically from familyowned enterprises and foreign firms, mainly from the United Kingdom and other European countries, as a result of British colonisation (Abdul Rahman, 2006). Despite the rapid growth of Malaysia's economy, the concentrated structure has 
not been diluted (Tam \& Tan, 2007). The introduction of the 'Look East' policy in the 1980s attracted many investments from Japanese corporations via jointventures with local partners, and also resulted in concentrated ownership. Furthermore, the initial public offerings by family-controlled companies and the privatisation of key state enterprises also led to highly-concentrated shareholdings.

In addition, the pyramidal ownership structure is a common feature of firms in Malaysia and other East Asia countries (Claessens, Djankov, \& Lang, 2000). Several factors have led to use of this structure, including: (i) to minimise the controlling stakeholder stake, (ii) to maximise the dilution of outside shareholdings by a reduction in the ratio of voting rights to cash flow rights (Burkart, Gromb, \& Panunzi, 1997); and (iii) to use as a means of limiting the liability of the controlling shareholder (Akoi, 1999).

Figure 3.1 illustrates an example of pyramidal structure in a Malaysian firm. Johor Corporation, a wholly owned subsidiary of the State Government of Johor, owns $53.22 \%$ of Kulim Berhad, who owned $59.58 \%$ of shares in QSR Berhad. QSR Berhad controls of KFC Holdings Berhad, through a 50.25\% shareholding. As such, Johor Corporation has established control over KFC Berhad, through their control of Kulim Berhad and QSR Berhad, even with only $15.93 \%$ of cash flow rights. The reduction in the ratio of voting rights to cash flow rights in a pyramidal structure allows the holding firm, i.e. family firms and state-controlled firms, to establish control with minimal capital investment by maximizing the dilution of outside shareholdings. 


\section{Figure 3.1}

Pyramidal structure of a Malaysian firm (Johor Corporation)

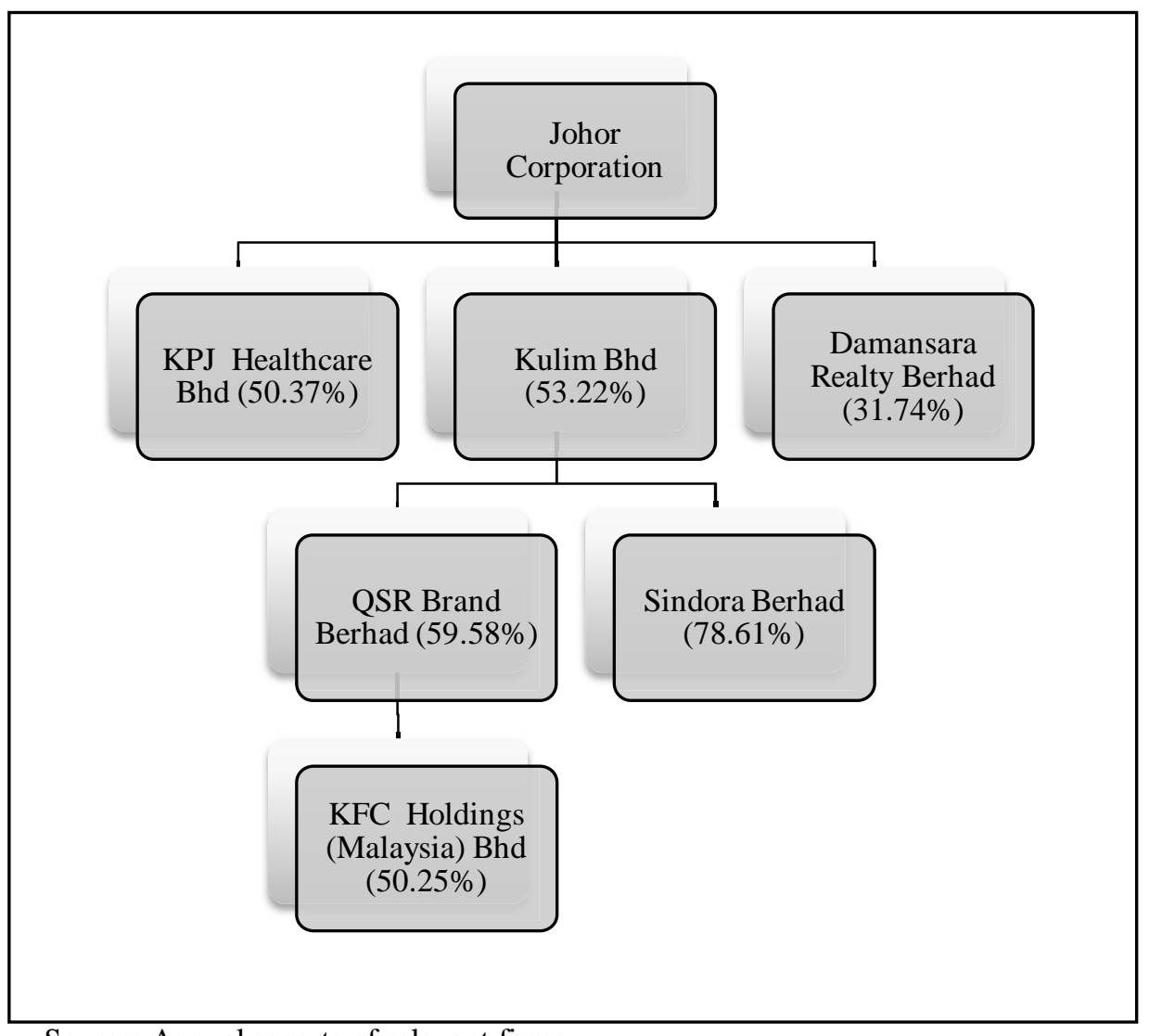

Source: Annual reports of relevant firms

To provide greater understanding of the ownership structure of Malaysian listed firms, the following subsections outline the characteristics of family firms and state-controlled firms.

\subsubsection{Family Firms}

The dominance of family firms in the Malaysian economy, especially those owned by Chinese families, started well before the independence of Malaysia. A survey by the World Bank (1999) found that $85 \%$ of the firms surveyed had owner-managers and that the post of CEO, chairman of the board or vice 
chairman belonged to a member or nominee of the controlling family. Another study by Claessens et al. (2000) found that around $40 \%$ of 238 sample firms in Malaysia were closely held by a single large shareholder, i.e. a family. Further, a joint survey by Shamsir Jasani Grant Thornton and Malaysia Institute of Management (2002) indicated that most of the businesses in Malaysia were managed by their founder (59\%), while $30 \%$ were managed by the second generation, the majority of whom were the children of the founder.

Table 3.5

Ownership of YTL Corporation and its holding company

Panel A: List of Five Largest Shareholders in YTL Corporation Berhad

\begin{tabular}{lcc}
\hline \multicolumn{1}{c}{ Name of shareholders } & Shareholdings & $\%$ \\
\hline Yeoh Tiong Lay \& Sons Holdings Sdn Bhd & $\mathbf{7 9 0 , 3 6 2 , 6 1 1}$ & $\mathbf{5 2 . 8 3}$ \\
Employees Provident Fund Board & $181,914,264$ & 12.16 \\
Skim Amanah Saham Bumiputera & $43,420,000$ & 2.90 \\
Fidelity Contrafund & $20,877,500$ & 1.40 \\
Amanah Saham Wawasan 2020 & $17,018,600$ & 1.14 \\
\hline \multicolumn{1}{c}{ Total } & $1,053,592,975$ & 70.43 \\
\hline \multicolumn{1}{c}{ Name of shareholders } & & \\
Panel B: List of Substantial Shareholders of Yeoh Tiong Lay \& Sons Holdings Sdn Bhd & $\%$ \\
\hline \multicolumn{2}{c}{ Yhareholdings } \\
\hline Yeoh Tiong Lay (Founder of YTL Group) & $8,220,004$ & 20.18 \\
Francis Yeoh Sock Ping (son-CEO of YTL Group) & $5,000,000$ & 12.28 \\
Yeoh Seok Kian & $5,000,000$ & 12.28 \\
Yeoh Soo Min & $1,250,000$ & 3.07 \\
Yeoh Seok Hong & $5,000,000$ & 12.28 \\
Michael Yeoh Sock Siong & $5,000,000$ & 12.28 \\
Yeoh Soo Keng & $1,250,000$ & 3.07 \\
Mark Yeoh Seok Kah & $5,000,000$ & 12.28 \\
\hline
\end{tabular}

Source: Annual report (2008) of YTL Corporation Berhad

The Yeoh family, the owner of one of the biggest conglomerates in Malaysia, is a 
prime example of this. ${ }^{11}$ Yeoh Tiong Lay founded the YTL Corporation Berhad, together with other listed subsidiaries such as YTL Power International Berhad, YTL Cement Berhad, YTL Land and Development Berhad, YTL E-Solutions Bhd, and YTL Industries Berhad. Using a private holding company, Yeoh Tiong Lay \& Sons Holdings Sdn Bhd, the Yeoh family owns and controls $52.83 \%$ of shares in YTL Corporation Berhad (as reported in Panel A Table 3.5). Panel B Table 3.5 reports that the Yeoh family owned 35,720,004 shares, equivalent to $87.72 \%$ of shares, of the private holding company, Yeoh Tiong Lay \& Sons Holdings Sdn Bhd. The details are reported in Panel B Table 3.5.

The growth in the number of family firms in Bursa Malaysia also relates to a change in the Listing Requirements of Bursa Malaysia in 1998, in which the minimum paid-up ordinary share capital was reduced to not less than MYR 40 million (Salleh, 2009). This change led to a substantial number of new listings of small firms, predominantly family firms. ${ }^{12}$

\subsubsection{State-Controlled Firms}

The government's involvement in listed firms started with the launch of the New Economic Policy in 1969, with the aim of eradicating poverty and reducing social inequality. Among the impacts of the policy was a significant shift of ownership

\footnotetext{
${ }^{11}$ In December 2008, the group record a total market capitalisation of about MYR 36.4 billion.

${ }^{12}$ Bursa Malaysia rules: (1) the company is incorporated in Malaysia, (2) the paid-up ordinary share capital is not less than MYR 40 million, (3) at least $25 \%$, but not more than $50 \%$, of the paid-up capital is in the hands of a minimum of 500 public shareholders holding not less than 1000 shares each, (4) the company has five consecutive years of after-tax profit of at least MYR 1 million and an aggregate after-tax profit of not less than MYR 12 million over the same five years, and (5) the company complies with the corporate disclosure requirements and other rules and bylaws of the Bursa Malaysia.
} 
and control from foreign companies to local entities, e.g. Guthrie, Sime Darby and Golden Hope. The famous 'dawn raid' on the London Stock Exchange was an example of a massive affirmative strategy to regain control of Malaysian assets from British interests. On September 7, 1981, Permodalan Nasional Berhad (PNB) made a successful take-over of $50.41 \%$ of shares of Guthrie Corporation, which was listed on the London Stock Exchange. The successful 'Dawn Raid', as it was commonly termed by the London brokers, enabled PNB to control Guthrie Corporation, a large plantation company in Malaysia controlling more than 76,000 hectares of rubber, oil palm and cocoa.

In 1983, the Malaysian government announced a privatization policy with the objectives of relieving the financial and administrative burden of the government and reducing the size of the public sector. In addition, the policy aimed to increase competition, efficiency, productivity, and economic growth through private entrepreneurship and investments (see Economic Planning Unit Prime Minister's Department of Malaysia, 1985, 1991). The privatization strategy resulted in the incorporation and listing of numerous state-controlled listed firms such as Tenaga Nasional Berhad (the national power generator and distributor), Malaysian Airline System Berhad (the national airline), and Telekom Malaysia Berhad (the national telecommunications provider). Several methods of privatization were employed, but the most significant were 'Share Issue Privatizations'. Table 3.6 presents examples of privatized state-owned enterprise through share issue privatization.

Even though the shares of these listed firms are made available to the public for investment, the Malaysian government, through the Ministry of Finance and other 
Government-Linked Investment Companies (GLICs), owns substantial amounts of the shares, especially in firms of public importance. For instance, in the utility, plantation, and financial sectors, privatised firms remain in government control. In contrast, the government disposed entirely of its holdings in certain business entities to private investors. For example, Sports Toto Malaysia Sdn Bhd, which ran Toto betting, was privatised in 1985 when its Chief Executive Officer, Vincent Tan Chee Yioun, acquired $70 \%$ of the paid-up capital through his private company.

Table 3.6

Share Issue Privatization in Malaysia (1983-1999)

\begin{tabular}{|c|c|c|c|}
\hline No & Company & Prospectus Date & Listing Date \\
\hline 1. & Bina Darulaman Bhd & 23 December 1995 & 2 February1996 \\
\hline 2. & Cahya Mata Sarawak Bhd & 22 December 1988 & 2 February 1989 \\
\hline 3. & Carpets International Malaysia Bhd & 10 June 1992 & 27 July 1992 \\
\hline 4. & Cement Industry of Malaysia Bhd & 7 May 1984 & 26 June 1984 \\
\hline 5. & Edaran Otomobil Nasional & 8 June 1990 & 26 July 1990 \\
\hline 6. & Far East Holdings Bhd & 22 December 1990 & 31 January 1991 \\
\hline 7. & Johore Tenggara Oil Palm Bhd & Privatised in 1994 & 15 August 1996 \\
\hline 8. & Kedah Cement Holdings Bhd & 9 December 1991 & 29 January 1992 \\
\hline 9. & Kelang Container Terminal Bhd & 25 September 1992 & 23 November 1992 \\
\hline 10. & KPJ Healthcare Bhd & 18 October 1994 & 29 November 1994 \\
\hline 11. & Malaysia International. Shipping Corp. Bhd & 29 December 1986 & 27 February 1987 \\
\hline 12. & Malaysian Airline System Bhd & 18 September 1985 & 16 December 1985 \\
\hline 13. & Padiberas Nasional Berhad & 12 January 1996 & 25 August 1997 \\
\hline 14. & Pasdec Holdings Bhd & 5 September 1997 & 27 October 1997 \\
\hline 15. & Pernas International Hotels \& Properties Bhd & 8 August 1990 & 25 September 1990 \\
\hline 16. & Perusahaan Otomobil Nasional Bhd & 21 January 1992 & 26 March 1992 \\
\hline 17. & Petronas Dagangan Berhad & 20 January 1994 & 8 March 1994 \\
\hline 18. & Petronas Gas Bhd & 14 July 1995 & 4 September 1995 \\
\hline 19. & SAP Holdings Bhd & 30 September 1994 & 7 November 1994 \\
\hline 20. & Sindora Berhad & 24 October 1995 & 7 December 1995 \\
\hline 21. & Sports Toto Malaysia Bhd & 1 August 1985 & Listed in 1987 \\
\hline 22. & Tenaga Nasional Berhad & 29 February 1992 & 28 May 1992 \\
\hline 23. & Telekom Malaysia Berhad & 26 September 1990 & 7 November 1990 \\
\hline 24. & Tradewinds (M) Bhd & 28 January 1988 & 23 March 1988 \\
\hline
\end{tabular}

Note: There are a total of 38 Share Issue Privatizations in Malaysia during 1983-1999 in Malaysia. Source: Sun, Qian, and H. S. Tong Wilson. 'Malaysia Privatization: A Comprehensive Study', Financial Management Vol. 31, No. 4, 79-105, 2002.

In certain cases, the government holds golden shares, which enable the holder (government) to outvote or veto all other shares (World Bank, 1999). For 
example, certain matters require the express consent of the holder of the share or it may confer special rights in the appointment of the board of directors (World Bank, 1999). As such, the government has a power to appoint board members and senior management, and to make major decisions such as contract awards and restructuring and divestments, though in most cases it is not the ultimate beneficial owner.

Government has significant participation in the economy. It is exercised by holding equity in the private sector; in particular in state-controlled firms, which are also known as Government-Linked Companies (GLC). Though the number of state-controlled firms is relatively small, representing less than $10 \%$ of the firms listed on Bursa Malaysia, these firms account for approximately MYR 260 billion in market capitalisation, or approximately $36 \%$ of the Bursa Malaysia market capitalisation. Table 3.7 shows the statistics for state-controlled firms in Bursa Malaysia.

Table 3.7

Government-Linked Companies in Bursa Malaysia

\begin{tabular}{lc}
\hline \multicolumn{1}{c}{ Variable } & Statistic \\
\hline No of Companies & 57 \\
Market Capitalisation (MYR billion) & 261 \\
\% Bursa Malaysia Composite Index & 54 \\
\% of Bursa Malaysia & 36 \\
No of Employees -estimate ' 000 & 400 \\
\hline
\end{tabular}

source: Putrajaya committee, high performance GLC, handbook of transformation plan (as at 26 July 2005)

Government control of public firms is achieved using various agencies and investment entities. Khazanah Nasional (Khazanah) is an investment holding arm of the Government of Malaysia and has investments in over 50 major firms 
covering a broad spectrum of industries. Khazanah is responsible for driving shareholder value creation and enhancing corporate governance in firms controlled by the government. Apart from Khazanah, Petroliam Nasional (Petronas), a national and wholly-owned oil company, has also invested a substantial amount of capital in the equity market.

The Malaysian capital market also has significant investments from other government agencies and fund managers, such as the Employees Provident Fund, Kumpulan Wang Persaraan, Lembaga Tabung Angkatan Tentera, Lembaga Tabung Haji, and Permodalan Nasional Berhad. The Employees Provident Fund (EPF), for example, was established under the Employees Provident Fund Act 1991 (Act 452) to provide retirement benefits for its members. Currently, employees contribute $11 \%$ of their pay, while employers contribute $12 \%$ to the fund. Kumpulan Wang Persaraan is a fund providing retirement benefits specifically for the public sector. In addition, Lembaga Tabung Angkatan Tentera (LTAT) is a superannuation scheme for serving members of the Armed Forces. For officers, participation is voluntary, but other ranks are required to contribute $10 \%$ of their monthly salary to LTAT, while the government, as employer, contributes $15 \% .^{13}$ The LTAT fund has invested in several areas, including retail business and cash investments such as bonds, fixed deposits and equities. In addition, Boustead Holdings Berhad, a subsidiary of LTAT, is invested in various businesses including plantations, heavy industries, properties, finance,

\footnotetext{
${ }^{13}$ For officers, participation is voluntary and the contributions are a minimum of RM 25 with a maximum of RM750 monthly.
} 
pharmaceuticals, manufacturing, and trading. ${ }^{14}$

On 17 March 1978, the Malaysian government established the Permodalan Nasional Berhad (PNB) to encourage share ownership among Bumiputera. ${ }^{15}$ Initially, PNB catered for only one ethnic group. The PNB mutual fund, Amanah Saham Nasional, for instance, was entirely for members of the bumiputera ethnic group. Subsequently, the PNB introduced other mutual funds such as Amanah Saham Wawasan 2020, Amanah Saham Malaysia, Amanah Saham 1Malaysia, and Amanah Saham Gemilang, in which all Malaysians are eligible to invest. Currently, the PNB investments involve more than 360 firms in Malaysia. In addition, the PNB has gained control of Malayan Banking Berhad, NCB Holdings Berhad, MNI Holdings Berhad, and Sime Darby Berhad. ${ }^{16}$

The Lembaga Tabung Haji (or Future Pilgrims Fund Corporation) was set up in 1963 to help the Malaysian Muslim community in performing Hajj (pilgrimage). Previously, pilgrims from rural areas sold their livestock or properties to cover their hajj (pilgrimage) expenses. The establishment of Lembaga Tabung Haji helps them to plan their savings for the pilgrimage, and provides pilgrimage management services. In 1969, the Pilgrimage Fund Management Board was established under the Pilgrimage Fund and Management Board Act 1969 (Act no 8), which marked significant investment of Lembaga Tabung Haji in the

\footnotetext{
${ }^{14}$ See Lembaga Tabung Angkatan Tentera's website for more information, available for access at http://www.ltat.org.my/

${ }^{15}$ Bumiputera means in Malay "sons of the soil". It refers to Malays and other indigenous people as distinct from Chinese, Indians, and other non-indigenous residents.

${ }^{16}$ See Perbadanan Nasional Berhad's website for more information, available for access at http://www.pnb.com.my/index.cfm.
} 
Malaysian capital market. Currently, Lembaga Tabung Haji controls two public listed firms: TH Plantations Berhad and Bank Islam Malaysia Berhad, which is involved in the business of oil palm plantations and Islamic banking respectively. $^{17}$

ValueCap and Social Security Organization (SOCSO) also invested funds in Bursa Malaysia. Khazanah Nasional Bhd, Permodalan Nasional Bhd, and Kumpulan Wang Persaraan equally own ValueCap, which invests heavily in highgrowth stocks. On the other hand, SOCSO was established in 1971 under the Employees' Social Security Act 1969 (Act 4) and is responsible for social security schemes, namely the Invalidity Pension Scheme and the Employment Injury Insurance Scheme. Through these schemes, SOCSO protects workers against industrial accident, including accidents that occur while working, occupational diseases, becoming an invalid, or death due to any cause. Workers contribute monthly to SOCSO, which then invests in various instruments including the equity market.

Other than the federal government, Malaysia has thirteen state governments. Every state government has established a State Economic Development Corporation (SEDC), which acts as the investment holding arm of the State. For example, Johor Corporation, an investment arm for the Johor State Government, has significant investments in the Malaysian economy, with more than 280 member companies. These include several listed firms (as shown in Figure 3.1)

\footnotetext{
17 See Lembaga Tabung Haji's website for more information. Available for access at www.tabunghaji.gov.my
} 
such as KPJ Healthcare Bhd, Kulim Bhd, Damansara Realty Bhd, QSR Brand Bhd, Sindora Bhd, and KFC Holdings Bhd.

Table 3.8 shows how the government has established control of Malayan Banking Berhad (Maybank), one of the biggest financial institutions in Malaysia. The largest shareholder in Maybank is Skim Amanah Saham Bumiputera, a mutual fund under Permodalan Nasional Berhad (PNB), which owns 44.67\% of shares. The Employees Provident Fund holds another $10.25 \%$ of shares. In addition, PNB itself holds $6.57 \%$ of shares, while Kumpulan Wang Persaraan, the pension fund for civil servants, holds another $2.55 \%$ of shares. Finally, a government agency involved in development of land, FELDA, owns 124 million shares in Maybank, bringing Malaysian government investment in Maybank to $65.89 \%$ of shares.

Table 3.8

Substantial shareholders of Malayan Banking Berhad

\begin{tabular}{lrr}
\hline \multicolumn{1}{c}{ Name of shareholders } & Shareholdings & \multicolumn{1}{c}{$\%$} \\
\hline Skim Amanah Saham Bumiputra & $2,180,681,634$ & 44.67 \\
Employees Provident Fund Board & $500,281,336$ & 10.25 \\
Permodalan Nasional Berhad & $320,776,808$ & 6.57 \\
Kumpulan Wang Persaraan (Diperbadankan) & $137,195,625$ & 2.55 \\
Lembaga Kemajuan Tanah Persekutuan (FELDA) & $124,622,156$ & 1.85 \\
Total & $3,263,557,559$ & 65.89 \\
\hline
\end{tabular}

Source: 2008 Annual report of Maybank Berhad

In January 2005, the government established the Putrajaya Committee on GLC High Performance (PCG) to develop comprehensive national policies and guidelines to transform GLCs into high-performing entities. A report issued by PCG shows that the performance of GLCs is below the market average (PCG, 2005). A substantial number of GLCs were also removed from the official list of Bursa Malaysia because of poor performance. Table 3.9 presents the summary of 
GLCs that were delisted from Bursa Malaysia over the period 2005 to 2009. PCG is responsible for implementing and overseeing the implementation of these policies and guidelines to transform GLCs into high-performing firms. To improve the performance of GLCs, several restructuring strategies have been undertaken, including the merger of Kumpulan Guthrie Bhd, Sime Darby Bhd, Golden Hope Plantations Bhd, and the bulk of their subsidiaries.

In terms of corporate governance, PCG has undertaken various initiatives to strengthen the governance of state-controlled firms. On 29 July 2005, PCG introduced the 'Green Book', a framework to guide GLC transformation and upgrade the effectiveness of GLCs' boards of directors. The transformation programme covers comprehensive aspects of firm management, including guidelines and programmes to enhance the effectiveness of the board of directors and reinforce strong corporate governance in state-controlled firms. Section 2 of the Green Book specifies corporate governance aspects such as board composition, separation of the roles of the Chairman and CEO, a cap on the number of directorships, directors' compensation, an annual review of Director and Board performance and many others. In addition, on 23 March 2006, to promote financial transparency fifteen GLCs made public their key performance indicators (KPI) and financial and operational targets in local newspapers (New Straits Times, 23 March 2006). 
Table 3.9

Summary of government-linked companies delisted from Bursa Malaysia

\begin{tabular}{|c|c|c|c|}
\hline No & Company & Main shareholders & Delisting Date \\
\hline 1. & Pelangi Bhd & $\begin{array}{l}\text { Perbadanan Nasional Bhd }(49.42 \%) \\
\text { Skim Amanah Saham Bumiputera }(25.33 \%)\end{array}$ & 15 August 2005 \\
\hline 2. & $\begin{array}{l}\text { Tractors Malaysia } \\
\text { Holdings Bhd }\end{array}$ & $\begin{array}{l}\text { Sime Darby Bhd }(71.74 \%) \\
\text { Employees Provident Fund Board }(5.32 \%)\end{array}$ & 24 February 2006 \\
\hline 3. & MNI Holdings Bhd & $\begin{array}{l}\text { Skim Amanah Saham Bumiputera }(66.56 \%) \\
\text { Employees Provident Fund Board }(9.19 \%) \\
\text { Permodalan Nasional Bhd }(7.68 \%)\end{array}$ & 23 March 2006 \\
\hline 4. & CIMB Bank & $\begin{array}{l}\text { Commerce Asset-Holding Bhd }(61.37 \%) \\
\text { Commerce Asset-Holding Bhd }(9.92 \%)\end{array}$ & 6 April 2006 \\
\hline 5. & Johan Ceramics Bhd & $\begin{array}{l}\text { Lembaga Tabung Angkatan Tentera } \\
(59.92 \%) \\
\text { Lembaga Tabung Haji }(11.92 \%)\end{array}$ & 13 April 2007 \\
\hline 6. & UDA Holdings Bhd & Khazanah Nasional Bhd (50.01\%) & 31 May 2007 \\
\hline 7. & $\begin{array}{l}\text { Island \& Peninsular } \\
\text { Bhd }\end{array}$ & $\begin{array}{l}\text { Permodalan Nasional Bhd }(79.94 \%) \\
\text { (nominees) } \\
\text { Permodalan Nasional Bhd }(16.72 \%)\end{array}$ & 13 July 2007 \\
\hline 8. & Opus Group Bhd & UEM World Bhd $(62.37 \%)$ & 19 October 2007 \\
\hline 9. & $\begin{array}{l}\text { Malaysian Industrial } \\
\text { Development Finance } \\
\text { Bhd }\end{array}$ & $\begin{array}{l}\text { Skim Amanah Saham Bumiputera }(48.78 \%) \\
\text { Permodalan Nasional Bhd }(20.17 \%)\end{array}$ & 30 October 2007 \\
\hline 10. & $\begin{array}{l}\text { Sime UEP Properties } \\
\text { Bhd }\end{array}$ & $\begin{array}{l}\text { Sime Darby Bhd }(51.15 \%) \\
\text { Skim Amanah Saham Bumiputera }(23.19 \%) \\
\text { Employees Provident Fund Board }(8.04 \%)\end{array}$ & 30 November 2007 \\
\hline 11. & $\begin{array}{l}\text { Sime Engineering } \\
\text { Services Bhd }\end{array}$ & $\begin{array}{l}\text { Sime Darby Bhd ( } 70.03 \%) \\
\text { Employees Provident Fund Board }(6.21 \%)\end{array}$ & 30 November 2007 \\
\hline 12. & $\begin{array}{l}\text { Mentakab Rubber } \\
\text { Company (Malaya) } \\
\text { Bhd }\end{array}$ & $\begin{array}{l}\text { Chermang Development (Malaya) Sdn. Bhd. } \\
\text { (a subsidiary of Golden Hope) }(57.17 \%) \\
\text { Golden Hope Plantations Bhd }(12.75 \%)\end{array}$ & 30 November 2007 \\
\hline 13. & $\begin{array}{l}\text { Kumpulan Guthrie } \\
\text { Bhd }\end{array}$ & $\begin{array}{l}\text { Permodalan Nasional Bhd }(54.29 \%) \\
\text { Skim Amanah Saham Bumiputera }(10.43 \%) \\
\text { Employees Provident Fund Board }(7.08 \%)\end{array}$ & 30 November 2007 \\
\hline 14. & $\begin{array}{l}\text { Golden Hope } \\
\text { Plantations Bhd }\end{array}$ & $\begin{array}{l}\text { Skim Amanah Saham Bumiputera }(38.35 \%) \\
\text { Permodalan Nasional Bhd }(13.28 \%) \\
\text { Kumpulan Wang Amanah Pencen }(12.08 \%) \\
\text { Employees Provident Fund Board }(5.91 \%)\end{array}$ & 30 November 2007 \\
\hline 15. & Guthrie Ropel Bhd & Kumpulan Guthrie Bhd $(57.85 \%)$ & 30 November 2007 \\
\hline 16. & $\begin{array}{l}\text { Highlands and } \\
\text { Lowlands Bhd }\end{array}$ & $\begin{array}{l}\text { Kumpulan Guthrie Bhd (Guthrie) }(54.53 \%) \\
\text { Skim Amanah Saham Bumiputera }(12.94 \%) \\
\text { FELDA }(6.79 \%)\end{array}$ & 30 November 2007 \\
\hline 17. & Negara Properties Bhd & Golden Hope Plantations Bhd (56.48\%) & 6 December 2007 \\
\hline 18. & $\begin{array}{l}\text { Boustead Properties } \\
\text { Bhd }\end{array}$ & $\begin{array}{l}\text { Boustead Holdings Bhd }(65.01 \%) \\
\text { Lembaga Tabung Angkatan Tentera }(8.60 \%) \\
\text { Employees Provident Fund Board }(5.18 \%)\end{array}$ & 8 August 2008 \\
\hline 19. & $\begin{array}{l}\text { Cement Industries of } \\
\text { Malaysia Bhd }\end{array}$ & UEM World Bhd (50.56\%) & 13 November 2008 \\
\hline 20. & UEM Builders Bhd & $\begin{array}{l}\text { UEM World Bhd }(51.70 \%) \\
\text { Lembaga Tabung Haji }(5.56 \%)\end{array}$ & 21 November 2008 \\
\hline $\begin{array}{l}21 . \\
22 .\end{array}$ & $\begin{array}{l}\text { UEM World Bhd } \\
\text { Vads Bhd }\end{array}$ & $\begin{array}{l}\text { Khazanah Nasional Bhd }(57.90 \%) \\
\text { Telekom Malaysia Bhd }(64.77 \%)\end{array}$ & $\begin{array}{l}18 \text { February } 2009 \\
19 \text { February } 2009\end{array}$ \\
\hline
\end{tabular}

Source: Bloomberg business news retrieved from http://investing.businessweek.com, company announcement and annual report of listed firms retrieved from http://www.klse.com.my 


\subsection{Chapter Summary}

This chapter has focussed on issues pertaining to institutional reforms, including corporate governance and financial reporting, in Malaysia following the 1997 economic crisis. This chapter provides a brief explanation of the 1997 financial crisis, and a discussion of institutional reforms, in particular corporate governance and financial reporting. Finally, the chapter describes the unique ownership structure of Malaysian firms, in particular, family ownership and state-control. The next chapter sets out the objectives of the research and develops the hypotheses to be tested. 


\section{CHAPTER FOUR \\ RESEARCH OBJECTIVES AND HYPOTHESES \\ DEVELOPMENT}

\subsection{Introduction}

This chapter explains the research objectives and develops the hypotheses of the study. The next subsection, Section 4.2, describes the purpose of this research. The development of the hypotheses is presented in the four subsections of Section 4.3. Section 4.3.1 discusses the hypothesis on the level of earnings conservatism after the reforms; Section 4.3.2 discusses the hypothesis on the effect of the adoption of IFRS on earnings conservatism; Section 4.3.3 reviews the hypothesis on the influence of ownership structure, i.e. family firms and state-controlled firms, on earnings conservatism; and Section 4.3.4 develops the hypothesis on the relationship between corporate governance and earnings conservatism. A summary of this chapter is provided in Section 4.4.

\subsection{The Proposed Research}

Figure 4.1 presents a diagrammatic representation of the relationship examined in the study. First, this study examines the level of earnings conservatism after the reforms of corporate governance and financial reporting in Malaysia. Second, this study examines whether the adoption of new accounting standards, IFRS, has had any significant impact on the level of earnings conservatism. Third, this study investigates the effect of ownership structure on earnings conservatism. Finally, the relationship between corporate governance and earnings conservatism is 
examined, which covers three main aspects, namely: the characteristics of boards of directors; the characteristics of the audit committee; and the quality of external auditors.

Figure 4.1

Relationships Examined

Post institutional reforms period (2003-2008)

Pre- and post- IFRS adoption

structure (family, statecontrolled, widely-held firms)

Corporate governance

(characteristics of board of directors; audit committee and the quality of external auditor)

\subsection{Hypotheses Development}

The development of the hypotheses of the study is presented in the following sections. 


\subsubsection{Earnings Conservatism Following Institutional Reforms}

Despite the importance of earnings conservatism, empirical studies examining this issue in Malaysia remain sparse. The most significant study was carried out by Ball et al. (2003), who examine earnings conservatism in four East Asian countries (Malaysia, Singapore, Thailand and Hong Kong). Using a sample of 2,726 firm-year observations from 1984 to 1996, they find that the four East Asian countries have low levels of earnings conservatism, hence a low quality of financial reporting. From this finding, Ball et al. (2003) argue that incentives appear to dominate accounting standards as a determinant of financial reporting in Hong Kong, Malaysia, Singapore and Thailand. In terms of accounting standards, these countries were substantially influenced in the past by UK or US accounting standards, and continued to be influenced by the International Accounting Standards (IAS), which are perceived as 'high quality' standards. However, weak institutional structures appear to provide little incentives to prepare financial reports which report earnings conservatively.

Another study, by Bushman and Piotroski (2006), also includes Malaysian firms in its sample. To examine the effect of country-level institutions, including a country's legal/judicial system, securities laws, and political economy, on conservative accounting practices, Bushman and Piotroski (2006) examine a final sample of 86,927 observations drawn from 38 countries. Of the total sample, Malaysian firms contribute 2,348 firm-year observations from 1992 to 2001. Bushman and Piotroski find that of country-level institutions, those such as judicial systems, strong public enforcement aspects of securities law, and lower state involvement in the economy, significantly influenced the financial reporting 
incentives for conservative accounting. From the results reported in Bushman and Piotroski (2006), Malaysian firms recognise bad news in a more timely fashion than they recognise good news, which is in conflict with Ball et al.'s (2003) findings. However, while the study periods overlap, the Bushman and Piotroski's (2006) study period extends to a later date which includes the early post reform years.

To complement both studies, this study examines the current state of earnings conservatism following the institutional reforms discussed earlier in this study. The sample covers the period 2003-2008 and is thus different from Ball et al. (2003), who examine the period prior to the 1997 Asian financial crisis, and also later than Bushman and Piotroski (2006) whose sample extends only to the year 2001. Importantly, the results from this study will give better insight as to whether the period following the institutional reforms exhibits the presence of earnings conservatism.

This study predicts that earnings conservatism is a pervasive feature of Malaysian financial reporting following reforms to corporate governance and financial reporting. There are several reasons for this prediction.

First, after the 1997 Asian financial crisis, there were major reforms in the institutional structure governing Malaysian firms, including matters relating to corporate governance, securities laws, and financial reporting. Amongst the initiatives were (1) the introduction of the Financial Reporting Act (1997) in 1997; (2) the establishment of the Malaysian Accounting Standards Board 
(MASB) in 1997; (3) the establishment of the Malaysian Institute of Corporate Governance (MICG) in March 1998; (4) amendments to the Securities Industry Act (1983) in September 2003; (5) revision of the Malaysian Code of Takeovers and Mergers in 1999; (6) the issuance the Malaysian Code on Corporate Governance (MCCG) in March 2000; (7) the establishment of the Minority Shareholder Watchdog Group (MSWG) in August 2000; (8) the amendment of the listing requirements of the Bursa Malaysia to enable full effect to be given to the MCCG in January 2001; (9) the launch of Capital Market Master Plan (CMP) by Securities Commission in February 2001; (10) the issuance of the Best Practice in Corporate Disclosure by Bursa Malaysia in August 2004; (11) the adoption of IFRS in January 2006; (12) the introduction of the Green Book (Initiative on Board Effectiveness) by the Putrajaya Committee on GLC High Performance (PCG) to guide GLC transformation and upgrade the effectiveness of GLC Boards in April 2006; and (13) the revision of MCCG in 2007. These concerted initiatives by the regulators were undertaken to enhance public confidence in the Malaysian capital market and to strengthen the protection of investors.

Secondly, the period examined in this study is associated with high demand for conservative reporting due to several high-profile corporate scandals, which include the alleged failure of auditors to detect and persuade their clients to make timely recognition of economic losses. The high-profile corporate scandals in US firms such as Enron and WorldCom eroded investors' confidence in the securities markets and caused a credibility crisis in the accounting profession (Wall Street Journal, 2002 February 6). The share prices of the affected firms plummeted and this cost investors billions of dollars, hence exerting greater demand for earnings 
conservatism. Evidence from Lobo and Zhou (2006) shows an increase in conservatism in US firms' financial reports after the introduction of the SarbanesOxley Act, a regulatory measure introduced after the Enron scandal. In the Malaysian context, the failure of local firms such as Perwaja Steel, Technology Resources Industries, and Malaysian Airlines System, to name but a few, also eroded the confidence of the public in financial statements and thus created a strong demand for reporting that was more conservative.

From the above arguments, it is predicted that the period following the institutional reforms will exhibit earnings conservatism, as shown by the timelier recognition of bad news as opposed to good news. I conjecture that reforms in institutional structure, especially in corporate governance and financial reporting, create strong incentives for corporate managers, account preparers, auditors and investors to favour reporting earnings conservatively. The hypothesis is stated as follows (stated in the null form):

Ho1: Ceteris paribus, accounting earnings reported after the institutional reforms incorporate bad news (negative returns) and good news (positive returns) in the same way.

\subsubsection{IFRS Adoption and Earnings Conservatism}

Malaysia adopted the International Financial Reporting Standards (IFRS) from 1 January 2006 and the process is planned to reach full convergence by 1 January 2012. Since the adoption of IFRS represents a profound change in Malaysian financial reporting, it is appropriate to investigate whether the adoption of IFRS 
has had a significant impact on the quality of accounting information, i.e. earnings conservatism.

The adoption of IFRS could be expected to affect earnings conservatism in many ways. First, under IFRS, conservatism is no longer a desirable quality of financial statements. Previously, the need for conservatism was often linked to reliable reporting of past events, consistent with stewardship and the feedback function of accounting. Over time, international accounting standards have become increasingly future-oriented: their decision making function has assumed greater and greater importance (IASB, 2010), while conservatism as a governing principle has slipped in significance (Hellman, 2008). In the IASB (2010) Conceptual Framework, prudence (conservatism), which was one of the aspects of reliability in Concepts Statement 2 or the Framework (IASC, 1989), is not considered as an aspect of faithful representation. Prudence (conservatism) was removed because it is inconsistent with neutrality. This is a changed view compared with the prevailing IASB framework, but the change is not surprising given the deemphasis of conservatism in a number of standards issued by the International Accounting Standards Committee (IASC) and the IASB during the past decades.

Second, IFRS is increasingly permitting or requiring use of fair value accounting, while in the previous standards MASB employed principally historical cost accounting. On this basis, it is expected that the financial statements prepared under MASB standards could report more conservative earnings than those prepared under the IFRS standards. Historical cost accounting is associated with the concept of prudence, where appropriate provisions must be made for any 
potential losses; while for gains, only gains that meet the recognition criteria can be recorded, otherwise they are deferred until they are realisable. As such, the value of an asset would be impaired when its market value has fallen significantly; but the asset's value cannot be appreciated when the market value is higher than the purchase price. However, certain exceptions, such as the revaluation of assets, are permissible in Malaysia, thus allowing an increase in the value of property, plant, and equipment.

One example of the changes made by IFRS standards relates to accounting for goodwill (or, indeed, all indefinite life intangibles). Prior to IFRS, goodwill was normally capitalised and amortised over a number of years. ${ }^{18}$ In IFRS standards, no amortisation of goodwill is permissible. FRS 3 requires goodwill to be "tested for impairment annually, or more frequently if events or changes in circumstances indicate that it might be impaired" (para 55). This rule prevents excessive understatement of assets caused by goodwill amortisation, thereby reducing unconditional and overall conservatism. In contrast, the impairment testing rule ensures timely recognition of economic losses associated with goodwill, though it does not permit recognition of an increase in the value of goodwill.

Contrary to the above arguments, several studies argue that changes in accounting standards would not affect earnings conservatism. LaFond and Watts (2008) find that information asymmetry is positively related to conservatism. From the finding, LaFond and Watts (2008) argue that “... if the FASB was successful in

\footnotetext{
${ }^{18}$ There is no specific standard on goodwill in Malaysia prior to IFRS.
} 
meeting its stated goal of eliminating conservatism, then it would increase information asymmetry between investors, not reduce it. This outcome is inconsistent with the objectives of the Securities Acts" (p. 447). This argument is consistent with Watts' (2003a) explanation that conservatism arises not only from regulation, but also from contracting, litigation and taxation. Changes in one explanation may produce a minimal impact on overall earnings conservatism.

Consistent with this argument, several studies find that accounting standards have no influence on earnings conservatism. Ball and Shivakumar (2005), for example, find public and private firms in the United Kingdom have different levels of earnings conservatism, though subjected to similar accounting standards. Furthermore, Ball et al. (2003) find low earnings conservatism in Malaysia, Singapore, Thailand, and Hong Kong, although these countries adopted International Accounting Standards which were considered to be high-quality accounting standards.

This study aims to provide insight as to whether IFRS adoption has had any impact on earnings conservatism by resolving these conflicting arguments on the effect of accounting standards. To this end, this study tests the following hypothesis (stated in the null form):

Ho2: Ceteris paribus, there is no significant difference in the earnings conservatism level between pre- and post-IFRS adoption periods. 


\subsubsection{Ownership Structure and Earnings Conservatism}

The third objective of this study is to examine whether earnings conservatism varies accross different types of ownership structure. In contrast to developed countries where firms are typically widely-held, the ownership structure of Malaysian firms is highly concentrated, with control of many firms vested in either a family or government. The following section discusses the influence of family firms and state-controlled firms on earnings conservatism.

\subsubsection{Family Firms and Earnings Conservatism}

The relationship between family influence and earnings conservatism is closely related to the management entrenchment hypothesis and the convergence-ofinterest hypothesis (Morck, Shleifer, \& Vishny, 1988). The two hypotheses offer different predictions on the impact of owner-manager ownership of shares on agency conflicts, and expectations about firm financial performance and corporate reporting behaviour.

The management entrenchment hypothesis holds that higher levels of ownermanager ownership lead to entrenchment of management (Fan \& Wong, 2002; Morck, et al., 1988). The controlling shareholder, who has sufficient control over the board of directors, would pursue his own objectives without fear of disciplinary actions from other ownership interests; hence greater agency conflict between the controlling owner and minority shareholders (also known as Type II agency costs) is generated. That is, controlling shareholders are more likely to make decisions that maximise their wealth through expropriation of minority 
shareholders (Fan \& Wong, 2002). In term of earnings' reporting, the controlling shareholder has greater incentives to report earnings aggressively, as a means of channelling out the firm's wealth, i.e. via dividends, at the expense of other suppliers of funds.

The convergence-of-interest hypothesis posits that agency conflicts (Type I) decrease as an owner-manager's ownership interest increases. In addition, outside investors also perceive that managers have greater incentive to maximise firm value when their shareholding is high (Abbott, Parker, \& Peters, 2004; Fan \& Wong, 2002). A higher level of owner-manager ownership stake in the firm results in lesser divergence of interests, and therefore monitoring is less necessary (Menon \& Williams, 1994). In short, convergence of interest between the ownermanager and outside investors occurs (Feldmann \& Schwarzkopf, 2003).

With regard to this study, it is predicted that that the convergence-of-interest hypothesis provides better grounds for predicting the relationship between family firms and earnings conservatism. The prediction is based on several premises.

First, the interests of managers, who are members of the controlling family, are more aligned to the interests of the shareholders (Wang, 2006). For instance, they would forgo short-term benefits from manipulating earnings that can damage the firm's reputation (Wang, 2006), thereby alleviating agency costs. It is suggested that managers in family firms are also less likely to delay the recognition of bad news because this could damage the firm's long-term performance, the family reputation and the firms' stock value. This argument is consistent with several 
studies that find family firms produce higher quality earnings than widely-held firms (Ali, Chen, \& Radhakrishnan, 2007; Claessens, et al., 2000; Wang, 2006).

Second, managers in family firms have less incentive to report earnings aggressively because their compensation plan is not closely tied to reported earnings (Chen, 2005). In general, management compensation plans may trigger managers to performing aggressive reporting to maximise their benefits (Gaver, Gaver, \& Austin, 1995; Guidry, Leone, \& Rock, 1999; Healy, 1985), but this phenomenon is less prominent in family firms. With regards to family firms, the close relationship between managers and the controlling family leads to manager compensation that is less sensitive to changes in reported earnings because manager performance is more directly observable by the family (Brunello, Graziano, \& Parigi, 2003; Miller \& Le Breton-Miller, 2006). In addition, the appointment of managers in family firms is based on kinship ties; and in the area of employer-employee relationships, paternalism and unconditional loyalty take precedence over merit, experience, and educational qualifications (Yen, et al., 2007). These factors provide less incentive for managers to manipulate earnings or delay the recognition of bad news.

Third, I conjecture that family firms will report earnings conservatively to attract other investors and to maintain good relationships with lenders. Given that founders of family firms are long-term shareholders who view the firm as an asset to be passed along to heirs (Casson, 1999), they are less likely to issue new shares, since it might dilute their control. To finance new projects, family firms have to rely on banks or lenders as a source of capital. Thus, it is critical to have a good 
long-term relationship with these parties. Based on this argument, I expect family firms would report earnings conservatively as demanded by the debtholders.

Finally, large shareholdings in family firms leads to greater monitoring of managers by family members (Demsetz \& Lehn, 1985; Villalonga \& Amit, 2006), hence reducing the likelihood of aggressive reporting. Given that the controlling family has a long investment horizon (Anderson \& Reeb, 2003a), this helps mitigate myopic investment decisions by managers (James, 1999). The longer investment horizon of the controlling family (Anderson, Mansi, \& Reeb, 2003; Miller \& Le Breton-Miller, 2006) drives managers to pursue positive net present value projects even if doing so reduces short-term earnings. Given that the controlling shareholder has a long experience with the firm, they acquire firmspecific knowledge and industry-specific knowledge that enhances their monitoring effectiveness, especially in restraining opportunistic reporting by managers.

My prediction is also consistent with evidence from empirical studies of family firms and their earnings quality. For instance, Wang (2006) finds that family firms report better-quality earnings in terms of lower absolute abnormal accruals, a larger earnings response coefficient and less persistence of transitory loss components in earnings. Further, Ali, Chen, and Radhakrishnan (2007) find that family firms have higher earnings response coefficients, lower discretionary accruals, greater predictability of cash flows, and provide more voluntary disclosure of bad news. There are also studies that have opposite findings. Fan and Wong (2002), who examine 977 companies in seven East Asian countries, 
find that concentrated ownership and the associated pyramidal and cross-holding structures create agency conflicts between controlling owners and outside investors, and are hence associated with low earnings informativeness. Furthemore, Francis et al. (2005) predict and find that earnings are generally less informative, and dividends are at least as (if not more) informative for dual class firms (from with two classes of stock with equal cash flow rights but different voting rights).

In sum, based on the theoretical arguments and empirical evidence, it is predicted that family firms have greater incentives to report earnings conservatively. The hypothesis is stated as follows (stated in the null form):

\section{Ho3a: Ceteris paribus, in family firms, accounting earnings incorporate bad news and good news in the same way.}

\subsubsection{State-Controlled Firms and Earnings Conservatism}

In this section, I conjecture that state-controlled firms have unique incentives and demand for conservative reporting of earnings compared to both family firms and widely-held firms.

First, it is posited that state-controlled firms have poor monitoring mechanisms to curb aggressive earnings reporting. Compared to family firms and widely-held firms, the board of directors in state-controlled firms can be considered as weak and ineffective since the directors tend to be appointed from the set of persons who have a close relationship to the governing political party or who have served 
as senior government officers. For example, in Sime Darby Berhad, a statecontrolled firm, six out of the twelve directors have political connections or have served as senior government officers. The detailed profiles are reported in Table 4.1. Since the directors lack business experience, the board becomes ineffective and unable to monitor managers, especially when the business's operations are complex and diversified. Anecdotal evidence shows that state-controlled firms underperformed the broader Malaysian market in respect of all key financial indicators except for firm size (PCG, 2005). Recently, Sime Darby Berhad, Malaysia's second largest company by market value, lost MYR 964 million (US\$ $296 \mathrm{~m} / \mathrm{EUR} 240 \mathrm{~m}$ ) on four projects because of poor management decisions and control $^{19}$. This shows poor performance by directors in overseeing the business operation; and this is exacerbated when the firm size is large and the firm has diversified business operations.

Second, managers of state-controlled firms have a greater tendency to report aggressive earnings as a compensation maximisation strategy. Unlike in family firms, managers in state-controlled firms have greater incentives to delay the recognition of bad news to achieve higher reported earnings since their annual compensation is tied to the firm's financial performance. However, the difference in behaviour from other firms may not be significant. Anecdotal evidence shows that high-performance managers of state-controlled firms have greater opportunities for career development. For example, Tan Sri Amirsham Abdul

\footnotetext{
19 Source: The Star Online News Portal (a Press company in Malaysia) http://biz.thestar.com.my/news/story.asp?file=/2010/5/21/business/6307079\&sec=business retrieved on 30 May 2010.
} 
Aziz, a former CEO of Malayan Banking Berhad, was appointed as the Minister in charge of the Economic Planning Unit on March 18, 2008, while Dato' Sri Idris Jala, a former CEO of Malaysian Airlines System Berhad, was also appointed as a minister without portfolio in the Prime Minister's Department and the CEO of the Performance Management and Delivery Unit. Great opportunities for job promotion in state-controlled firms, including being appointed to a ministerial position, gives managers incentives to report higher reported earnings, in particular by delaying the recognition of bad news and accelerating the recognition of good news.

Third, state-controlled firms have complex ownership structures and more severe agency problems may occur (Shleifer \& Vishny, 1994) than in other firms. This prediction is based on the nature of GLCs, where the principal-agent relationship is broken down into two other agency relationships since the government acts simultaneously as the principal and agent. In relation to the managers of a government-owned company, the government is a principal, thus it must assign goals (Rodriguez, Espejo, \& Cabrera, 2007). The government is also the agent in its relationship with the public, the ultimate owners of the resources invested in by the government-owned company (Ernst, 2004). It is thus posited that the boards of directors of state-controlled firms are weak and ineffective compared to family firms and widely-held firms because board members are appointed by and accountable to the government, which is also the agent for the public. Since the government and the board of directors are also the agent, they themselves have private incentives. 


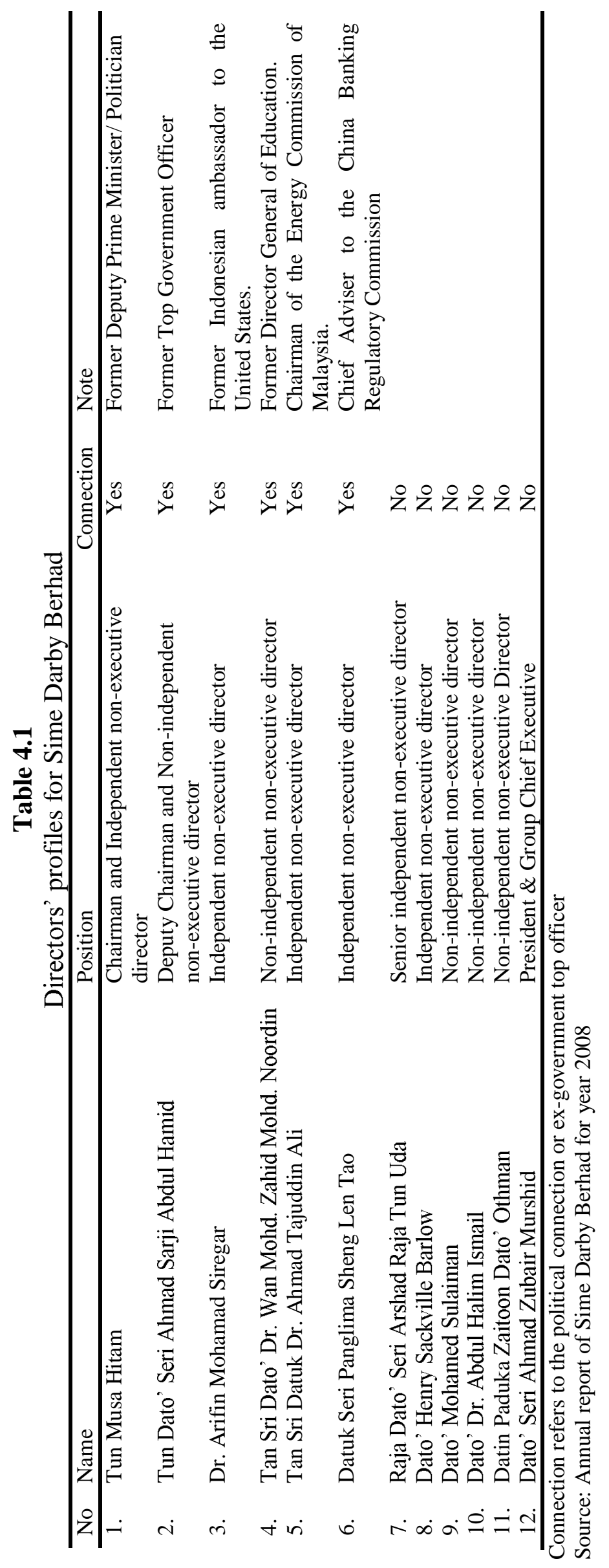


According to Downs's (1957) model of government, in the decision-making process government considers not only the interests of the public as voters, but also the plans or agendas of the opposition parties that compete for votes. Therefore, the government wants to control or monitor managers and managerial decisions so that the decisions are in line with its political interests.

From the above arguments, it is posited that the managers and directors of statecontrolled firms have incentives to opportunistically report higher earnings, achieved by delaying the recognition of bad news. This study tests the following hypothesis, stated in the null form:

\section{$H_{0} 3 b$ : Ceteris paribus, in state-controlled firms, accounting earnings incorporate bad news and good news in the same way.}

\subsubsection{Corporate Governance and Earnings Conservatism}

Corporate governance has a crucial role in monitoring and controlling the behaviour of senior managers and protecting the interests of different parties in the firm (Fama, 1980; Fama \& Jensen, 1983). Strong corporate governance is able to: (i) promote financial statement transparency; (ii) reduce accounting manipulation; (iii) limit the ability of managers to conceal bad news for a long period; (iv) enhance greater independence of the committees destined to monitor management; and (v) provide strong support to the expected bias of the auditor towards conservative reporting (García Lara, et al., 2007).

It is posited that strong corporate governance has a significant role in enhancing 
earnings conservatism. This assertion is made on the basis of several premises, as discussed below.

First, a strong board of directors demands higher earnings conservatism because it provides an early warning signal, which triggers a prompt investigation of the origin of bad news (García Lara, et al., 2007). Earnings conservatism is a mechanism that facilitates good governance, in that it ensures that assets are invested and used efficiently and prevents the inappropriate distribution of assets to managers or other parties. Timely recognition of bad news, for example, prevents managers from hiding less favourable information, thereby reducing the agency costs of the monitoring of contracts. For this reason firms with good corporate governance opt for high earnings conservatism.

Second, strong boards will force greater conservatism in order to reduce agency costs arising from asymmetric information between managers and other parties related to the firm, asymmetric payoff and limited liability (Watts, 2003a). In addition, stronger boards are likely to demand more conservative accounting since they are more proficient at efficient contracting and understand the benefits of conservatism (Ahmed \& Duellman, 2007). Consistent with this argument, García Lara et al. (2007) find that firms with a strong board, where the CEO has limited influence over the functioning of the board, exhibit a greater degree of earnings conservatism.

Third, conservative reporting of earnings in the financial statements helps the board of directors in evaluating managers' investment decisions and strategies. 
Conservatism ensures any decrease in the future cash flow from a negative NPV investment is reported in a timely fashion, thus allowing immediate corrective measures to be made by the board of directors. Furthermore, conservatism is an essential characteristic of a firm's accounting system that can help directors in reducing deadweight losses and moderating other sources of information, thereby increasing firm and equity values (Watts, 2003a).

Finally, conservatism reduces the litigation risk to the auditor and board of directors. Since the shareholders and debtholders prefer a downward bias in earnings in order to constrain management from aggressive accounting, directors and auditors reduce the litigation risk when exerting greater earnings conservatism. Furthemore, courts are more likely to award damages for overstated earnings or assets (Kellogg, 1984). Thus, firms with strong corporate governance would demand greater earnings conservatism.

In short, firms with good corporate governance will favour earnings conservatism. This is triggered by the roles and benefits of earnings conservatism, the demand of providers of funds to constrain aggressive accounting choices and practices, and the need of directors and auditors to reduce litigation risk. Based on the above arguments, A positive association is predicted between strong corporate governance and earnings conservatism. Thus, the fourth hypothesis is set as follows (stated in the null form):

$H_{0} 4:$ Ceteris paribus, the degree of earnings conservatism is not related to the quality of corporate governance. 


\subsection{Conclusions}

This chapter has discussed the research objectives of the study and the development of four hypotheses. The first hypothesis tests whether bad news is recognised in earnings in a more timely fashion than is good news, following the institutional reforms. The second hypothesis tests whether there is a significant change in earnings conservatism as a result of IFRS adoption. The third hypothesis tests whether earnings conservatism varies according to ownership structure, in particular, family firms and state-controlled firms. The final hypothesis tests the relationship between corporate governance and earnings conservatism.

The next chapter describes the research design and method, the sample used for the study, measurement of conservatism and other relevant variables, and the regression models to test the hypotheses. 


\section{CHAPTER FIVE RESEARCH METHODOLOGY}

\subsection{Introduction}

The present chapter concentrates on the research design and research method. Section 5.2 discusses the sample selection process. The measure for earnings conservatism is discussed in Section 5.3. Section 5.4 describes the process used for classifying the financial statements into pre- and post-IFRS periods. The measures of ownership structure are outlined in Section 5.5. Section 5.6 explains the measures for corporate governance. Section 5.7 describes the regression models used in this study, while Section 5.8 discusses the robustness tests employed in the analyses. The chapter concludes with Section 5.9.

\subsection{Sample Selection and Data Collection}

This study examines earnings conservatism issues in Malaysian listed firms following the institutional reforms discussed in Chapter 3. Basically this study focuses on a sample from 2003 to 2008 , but the calculation of certain variables such as earnings yield and stock returns requires one-year lag data. Figure 5.1 presents the statistics for listed firms in Bursa Malaysia from 2002 to 2008.

The sample selection process involves a number of steps. First, I identified all firms listed on Bursa Malaysia as at 31 December 2008. From the Worldscope database, I found a total of 977 listed firms as at that date. Second, I identified newly-listed firms from the years 2002 to 2008. These 349 firms were then 
excluded from the sample. Third, I excluded 37 firms listed in the financial sector in Bursa Malaysia. Fourth, I excluded 36 inactive firms, including all firms suspended from trading. Finally, I excluded 34 firms with missing and incomplete data. This process results in a final sample of 521 firms for the six-year period.

The sample selection process is summarised in Table 5.1.

Figure 5.1

Malaysian listed firms (2002-2008)

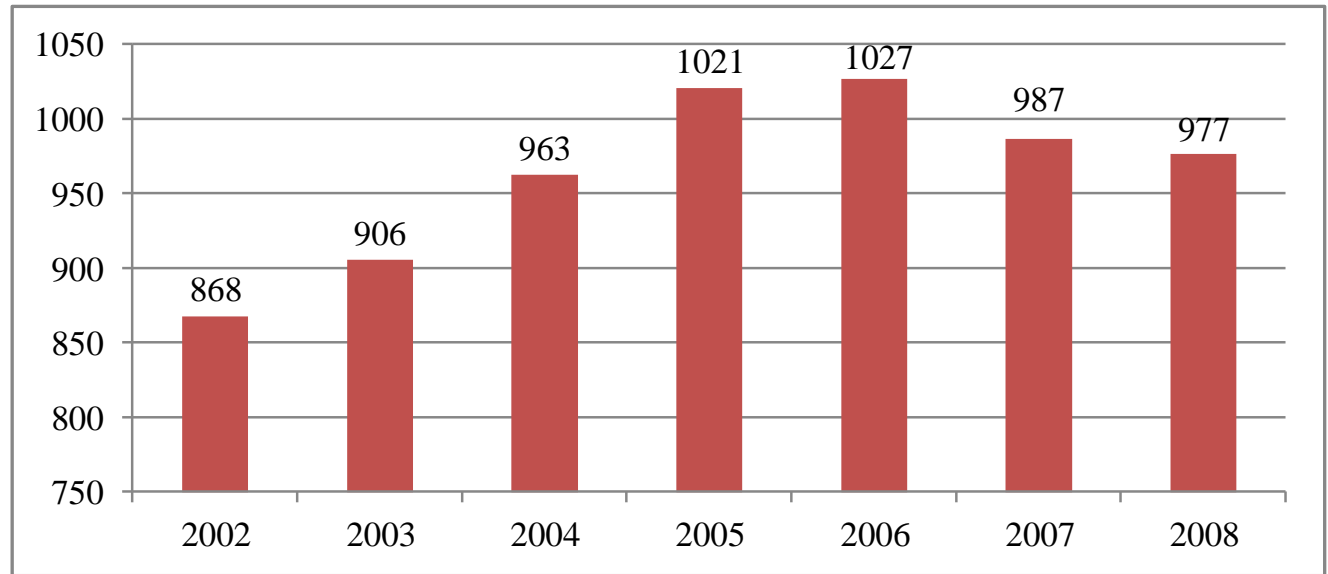

Source: Bursa Malaysia

Table 5.1

Sample selection process

Initial sample (as at 31 December 2008)

Excludes:

(i) Newly listed firms (2002 to 2008)

(ii) Financial sector

(iii) Inactive/suspended from trading

(iv) Missing and incomplete data

Final sample (per year) 
Table 5.2

List of variables, sources and definitions

\begin{tabular}{|c|c|c|c|}
\hline Variable & Symbol & Source & Definition/Formula \\
\hline Total assets & TASSETS & Worldscope & $\begin{array}{l}\text { Total current assets and noncurrent } \\
\text { assets. }\end{array}$ \\
\hline Total liabilities & TLIAB & Worldscope & Total short and long term liabilities. \\
\hline $\begin{array}{l}\text { Earnings before } \\
\text { interest and taxes }\end{array}$ & $E B I T$ & Worldscope & $\begin{array}{l}\text { The earnings of a firm before interest } \\
\text { expense and income taxes. }\end{array}$ \\
\hline Stock price & PRICE & Worldscope & The closing price of the security. \\
\hline Earnings per share & EPS & Worldscope & $\begin{array}{l}\text { Earnings per share earnings as reported } \\
\text { by the firms. }\end{array}$ \\
\hline $\begin{array}{l}\text { Cash flow from } \\
\text { operations }\end{array}$ & CFO & Worldscope & $\begin{array}{l}\text { The net cash receipts and } \\
\text { disbursements resulting from the } \\
\text { operations of the firm. }\end{array}$ \\
\hline $\begin{array}{l}\text { Industry } \\
\text { classification }\end{array}$ & INDUSTRY & $\begin{array}{l}\text { Bursa } \\
\text { Malaysia }\end{array}$ & $\begin{array}{l}\text { Dummy variables for industry, } \\
\text { including construction, consumer } \\
\text { product, hotel, IPC, industrial product, } \\
\text { plantation, property, technology, and } \\
\text { trading/services. }\end{array}$ \\
\hline Board size & \#BODSIZE & Annual Report & $\begin{array}{l}\text { Total number of directors in the board } \\
\text { of directors at financial year end. }\end{array}$ \\
\hline $\begin{array}{l}\text { Non-executive } \\
\text { directors }\end{array}$ & \#NONEXEC & Annual Report & $\begin{array}{l}\text { Total number of non-executive } \\
\text { directors at financial year end. }\end{array}$ \\
\hline $\begin{array}{l}\text { Independent } \\
\text { directors }\end{array}$ & \#BODINDP & Annual Report & $\begin{array}{l}\text { Total number of independent directors } \\
\text { at financial year end. }\end{array}$ \\
\hline $\begin{array}{l}\text { Independent } \\
\text { chairman }\end{array}$ & INDCHRM & Annual Report & $\begin{array}{l}\text { Dummy variable that takes value } 1 \text { if } \\
\text { the chairman of board of directors is a } \\
\text { non-executive independent director, } \\
\text { otherwise } 0 \text {. }\end{array}$ \\
\hline Board meeting & \#BODMEET & Annual Report & $\begin{array}{l}\text { Total number of meetings held by the } \\
\text { board of directors for the financial year. }\end{array}$ \\
\hline $\begin{array}{l}\text { Audit committee } \\
\text { size }\end{array}$ & \#ACSIZE & Annual Report & $\begin{array}{l}\text { Total number of directors in the audit } \\
\text { committee as at financial year end. }\end{array}$ \\
\hline $\begin{array}{l}\text { Audit committee } \\
\text { independence }\end{array}$ & \#ACINDP & Annual Report & $\begin{array}{l}\text { Total number of independent directors } \\
\text { on the audit committee. }\end{array}$ \\
\hline $\begin{array}{l}\text { Audit committee } \\
\text { financial expertise }\end{array}$ & \#ACEXPERT & Annual Report & $\begin{array}{l}\text { Total number of directors in audit } \\
\text { committee that have accounting or } \\
\text { finance degree or professional } \\
\text { qualification, or members of accounting } \\
\text { professional bodies, or have experience } \\
\text { working as chief financial officer. }\end{array}$ \\
\hline $\begin{array}{l}\text { Audit committee } \\
\text { meeting }\end{array}$ & \#ACMEET & Annual Report & $\begin{array}{l}\text { Total number of meetings held by audit } \\
\text { committee for the financial year. }\end{array}$ \\
\hline Size of Audit Firm & BIG4 & Annual Report & $\begin{array}{l}\text { Dummy variable that takes value } 1 \text { if } \\
\text { the firms audited by Big Four auditors, } \\
\text { otherwise } 0 \text {. }\end{array}$ \\
\hline $\begin{array}{l}\text { Number of Family } \\
\text { Directors on } \\
\text { Board of Directors }\end{array}$ & FAMDIR & Annual Report & $\begin{array}{l}\text { Total number of directors with family } \\
\text { relationship with each other and/or } \\
\text { major shareholders of the company. }\end{array}$ \\
\hline Family Ownership & FAMOWN & Annual Report & $\begin{array}{l}\text { Total percentage of shares owned by } \\
\text { the controlling family. }\end{array}$ \\
\hline $\begin{array}{l}\text { Government } \\
\text { Ownership }\end{array}$ & GOVOWN & Annual Report & $\begin{array}{l}\text { Total percentage of shares owned by } \\
\text { GLCs and GLICs. }\end{array}$ \\
\hline
\end{tabular}


For the data collection process, I extracted data from two sources: Worldscope electronic database and corporate reports. ${ }^{20}$ Firstly, I identified all variables required, as summarised in Table 5.2, and then performed a search in Worldscope. From the search, I found that financial and stock price data are downloadable from Worldscope, while corporate governance and ownership data are not available. As a solution, I downloaded 3,126 corporate reports from Bursa Malaysia website for all 521 firms for the six-year period. I then hand collected the corporate governance and ownership data from corporate reports. Description of the variables collected for this study are summarised in Table 5.2.

For industry classification, I classified the industry based on Bursa Malaysia's industry classification. I collected this information from Bursa Malaysia's official website. In addition, I also gathered information from various businesses' and organisations' websites, including the Khazanah Nasional and State Economic Development Corporation corporate websites.

\subsection{Measure of Earnings Conservatism}

Following the research design of Basu (1997), I use the asymmetric timeliness of earnings model as the primary measure for earnings conservatism. This measure has been widely used in many studies, for example Ball et al. (2000), Ball et al. (2003), Ball and Shivakumar (2005), Bushman and Piotroski (2006), Francis et al. (2004) and Roychowdury and Watts (2007). In this model, conservatism is

\footnotetext{
${ }^{20}$ Annual financial reports for Malaysian listed companies are available from Bursa Malaysia's website (http://www.bursamalaysia.com/website/bm/listed_companies/company_announcements/annual_r eports/index.jsp)
} 
defined as the extent to which current period accounting earnings asymmetrically incorporate economic losses relative to economic gain. Stock return is used as a proxy for economic income as it is assumed that stock prices reflect all available information, consistent with the evidence that stock prices lead earnings information (Ball \& Brown, 1968; Beaver, Lambert, \& Morse, 1980; Kothari \& Sloan, 1992). Following Ball, et al. (2000), Ball, et al. (2003), Bushman and Piotroski (2006), and Grambovas, et al. (2006), I use fiscal year return as a proxy for economic news. Accounting earnings imposes different verification standards for recognition of different types of economic news. For bad news (negative stock returns), lower verification standards are used, which results in the immediate recognition of losses. However, for good news (positive stock return), higher verification standards are imposed for gains to be recognised in accounting earnings. This approach results in a stronger positive association between bad news and earnings, which suggests the timelier reporting of bad news relative to that of good news.

Following Basu (1997), I estimate a linear regression of accounting earnings on stock returns as follows:

$$
E_{i t} / P_{i t-1}=\beta_{0}+\beta_{1} R E T_{i t}+\beta_{2} R D_{i t}+\beta_{3} R E T_{i t} * R D_{i t}+\varepsilon_{i t}
$$

where $E_{i t}$ is the earnings per share for firm $\mathrm{i}$ in fiscal year $\mathrm{t} ; P_{i t-1}$ is the price per share at the beginning of the fiscal year; $R E T_{i t}$ is the annual return of firm $\mathrm{i}$ in fiscal year $\mathrm{t} ; R D_{i t}$ is a dummy variable that equals 1 if $R E T_{i t}$ is negative, and 0 otherwise; and $\varepsilon_{i t}$ is the error term. 
In equation (5.1), $\beta_{1}$ measures the response of earnings to returns when returns are positive, and $\beta_{1}+\beta_{3}$ measures the response of earnings to negative returns. If $\beta_{1}+\beta_{3}>\beta_{1}$ or $\beta_{3}>0$ then earnings reflect bad news more quickly than they reflect good news, that is, earnings conservatism.

\subsection{Classification For Pre- and Post-IFRS Adoption}

Since this study aims to compare earnings conservatism before and after adoption of International Financial Reporting Standards (IFRS), it is crucial to determine the cut-off point for the date of IFRS adoption. The IFRS became effective and mandatory in Malaysia starting from 1 January 2006; hence the earliest published annual reports using these standards are financial statements dated 31 December 2006. Table 5.3 presents the breakdown of the observations based on the accounting standards.

Table 5.3

IFRS adoption and period classification

\begin{tabular}{|c|c|c|c|}
\hline Year & Financial Year End & $\mathrm{N}$ & IFRS Period \\
\hline 2004 & $\begin{array}{l}\text { 1 January } 2004 \text { to } \\
30 \text { December } 2004\end{array}$ & 227 & \multirow[b]{2}{*}{ Two-year prior to IFRS adoption } \\
\hline 2005 & $\begin{array}{l}31 \text { December } 2004 \\
\text { 1 January } 2005 \text { to } \\
30 \text { December } 2005\end{array}$ & $\begin{array}{l}294 \\
227\end{array}$ & \\
\hline 2006 & $\begin{array}{l}31 \text { December } 2005 \\
\text { 1 January } 2006 \text { to } \\
30 \text { December } 2006\end{array}$ & 227 & One-year prior to IFRS adoption \\
\hline 2007 & $\begin{array}{l}31 \text { December } 2006 \\
\text { 1 January } 2007 \text { to } \\
30 \text { December } 2007\end{array}$ & $\begin{array}{l}294 \\
227\end{array}$ & First year of IFRS adoption \\
\hline \multirow{2}{*}{2008} & $\begin{array}{l}31 \text { December } 2007 \\
\text { 1 January } 2008 \text { to } \\
30 \text { December } 2008\end{array}$ & $\begin{array}{l}294 \\
227\end{array}$ & \multirow[t]{2}{*}{ Second year of IFRS adoption } \\
\hline & 31 December 2008 & 294 & \\
\hline
\end{tabular}


I compare earnings conservatism for the short-horizon periods of one year and two years before and after IFRS adoption. For the main analysis, I examine two samples: (i) 1,042 firm-year observations for one year pre- and post-IFRS adoption for all firms; and (ii) 2,084 firm-year observations for two year pre- and post-IFRS adoption for all firms. I also conducted additional tests by limiting the sample to firms with a financial year end dated 31 December, which involve a sample of (i) 588 firm-year observations for one year pre- and post-IFRS adoption; and (ii) 1,176 firm-year observations for two year pre- and postadoption of IFRS.

\subsection{Measurement of Ownership Structure}

Previous studies refer to ownership structure as the distribution of equity and also the identity of the equity owners (Claessens, et al., 2000; Francis, Schipper, \& Vincent, 2005; Wang, 2006). Most of the studies of ownership structure focus on immediate ownership, such as equity directly owned by individuals or institutions. However, Fan and Wong (2002) argue that immediate ownership is not sufficient for characterising the ownership and control structure of East Asian firms, as these firms are generally associated with complicated indirect ownership. This study therefore focuses on ultimate ownership. I used data from various sources, including annual reports, corporate websites, and business magazines to identify the ultimate owners of Malaysian listed firms.

Following La Porta, Lopez-de-Silanes, and Shleifer (1999), I defined an ultimate owner as the shareholder who has the determining voting rights of the firm and who is not controlled by anybody else. This definition suits the pyramidal 
ownership structure which is a common feature of firms in Malaysia and other East Asia countries (Claessens, et al., 2000). If a firm does not have an ultimate owner, it is classified as widely held. For firms with an ultimate owner, I divide those firms into family or state-controlled firms

Identification of state-controlled firms was made on the basis of two sources. First, I used the list of firms announced by the Putrajaya Committee on GLC High Performance as being government-linked companies (GLCs), or their subsidiaries or affiliates, or government-linked investment companies (GLICs). This list includes firms in which the Federal Government of Malaysia has a direct or indirect controlling stake. ${ }^{21}$ This definition includes subsidiaries and affiliates of GLCs or GLICs. ${ }^{22}$ Second, I broadened the scope of state-controlled firms to include firms which are under direct or indirect control of any of the thirteen State Governments. ${ }^{23}$ For instance, Kumpulan Perangsang Selangor Berhad is a firm over which the State Government of Selangor has direct control; hence I classified this firm as a state-controlled firm. In Section 3.5.2, I discussed various examples of state-controlled firms, including firms which are controlled by state governments.

I followed Jaggi et al. (2009), Ho and Wong (2001) and Anderson and Reeb

\footnotetext{
${ }^{21}$ In addition to share ownership, 'direct controlling stake' also refers to the government's ability to appoint board members, senior management and make strategic decisions (e.g. award contract, strategy, restructuring and financing, acquisitions and divestments etc.).

${ }^{22}$ There are seven GLICs in Malaysia, namely Employees Provident Fund, Khazanah Nasional Bhd, Kumpulan Wang Amanah Pencen, Lembaga Tabung Angkatan Tentera, Lembaga Tabung Haji, Menteri Kewangan Diperbadankan, and Permodalan Nasional Bhd.

23 Apart from the federal government, Malaysia has thirteen state governments: Perlis, Kedah, Pulau Pinang, Perak, Selangor, Melaka, Negeri Sembilan, Johor, Pahang, Terengganu, Kelantan, Sabah, and Sarawak.
} 
(2003b), where family firms were indentified based on the presence of family members on the board of directors. If two or more members of the controlling family are present on the board, the firm would be classified as a family firm. ${ }^{24} \mathrm{~A}$ family relationship includes: father/mother, son/daughter, husband and wife, father/mother-in-law, son/daughter-in-law, brothers and sisters, nieces and nephews. However, I noticed one weakness when using this definition of family firms in relation to Malaysia. Certain firms in Malaysia have only one member of the controlling family sitting on the board of directors. Genting Berhad, for example, is a business controlled by the family of the late Lim Goh Tong through a private firm (Kien Huat Realty Sdn Berhad). His son, Lim Kok Thay, is the only member of Lim's family on the board of directors, but he also acts as the CEO and Chairman of the board. To reduce the classification bias, I also classified a firm as a family firm when a member of the controlling family (largest shareholder) holds the top executive position, either chief executive officer, managing director, president, or chairman of the board of directors.

\subsection{Measurement of Corporate Governance}

Corporate governance encompasses the various mechanisms available to constrain the opportunistic behaviour of management and, consequently, results in more credible and relevant accounting information for users. Extending previous studies (for example Ahmed \& Duellman, 2007; Beekes, et al., 2004; García Lara, et al.,

\footnotetext{
${ }^{24}$ I identified the family relationship from the disclosure of director's relationships with other directors and major shareholders that were disclosed in the directors' profile in the corporate annual reports. This information was publicly available since Bursa Malaysia requires all public firms to disclose the profile of all directors, including their family relationship with other directors and major shareholders.
} 
2007, 2009), I used various aspects of corporate governance including the board of directors, audit committee, and external auditor as indicators of corporate governance quality. Gompers, Ishii, and Metrick (2003) and Davila and Penalva (2006) argue that the use of indexes which aggregate several governance measures allow better classification of firms in accordance with the strength of their governance. This is consistent with the concept of corporate governance as a set of mechanisms that work together.

Following the approach of García Lara et al. (2007), who developed Gov6 and Gov8 scores from six and eight corporate governance variables respectively, I constructed a corporate governance index $(C G I N D E X)$ by using an unweighted aggregate of measurement on 11 corporate governance variables. In addition, I categorised the observations into three groups: (i) good governance sample (if CGINDEX is in the top third of the pooled sample), (ii) poor governance sample (if CGINDEX is in the bottom third of the pooled sample), and (iii) average governance sample (if CGINDEX is in the middle group of the pooled sample). The use of a broader set of variables enables each variable to complement the others and provide a better means to discriminate between strong and weak governance structures (García Lara, et al., 2007). The corporate governance variables employed in this study are as follows:

\section{(i) Board Size}

Board size is an important mechanism in ensuring board effectiveness. Prior studies, for example Yermack (1996), Conyon and Peck (1998), and 
Eisenberg, Sundgren, and Wells (1998), suggest that larger boards negatively impact on firm value and performance. In a report about corporate governance issued by the Finance Committee on Corporate Governance (FCCG) in 1999, Malaysian listed firms are reported to have an average of eight directors (Finance Committee on Corporate Governance, 1999). The Malaysian Code of Corporate Governance $(2000,2007)$ made no recommendation in respect to board size, but the Code suggests that every board should examine its size, with a view to determining the impact of the number of directors upon effectiveness. Jensen (1993) suggests that the optimal board size is between seven and eight members.

However, a recent study by Coles, Daniel, and Naveen (2008) argues that board size is a more complicated issue and find that the relationship between board size and Tobin's Q is U-shaped. Furthermore, Linck, Netter, and Yang (2008) find that firms choose board structure on the basis of the costs and benefits of monitoring and advising. Nevertheless, this study has followed Jensen's (1993) recommendation. I use eight as the optimal point for board size. Thus, BODSIZE takes the value of 1 (good governance) if the number of directors is eight or fewer; 0 otherwise.

(ii) Non-Executive Directors

The role of non-executive directors may be crucial for the resolution of agency problems between managers and shareholders (Fama, 1980; Fama \& Jensen, 1983). Having a high proportion of non-executive directors on the board is 
linked to a lower influence by the CEO and other executive directors. The careers of executive directors are primarily related to allegiance to the CEO, but non-executive directors include independent directors and other directors representing institutional investors. Thus, the presence of non-executive directors may be vital to enforcing strong monitoring of managers (Beekes, et al., 2004). The Cadbury Committee (1992) suggests that there should be at least three non-executive directors on the board, of which a majority should be independent. On the other hand, the Hampel Committee (1998) on corporate governance was of the opinion that if non-executive directors are to be effective on the board, they should make up not less than one third of the board, again a majority of which should be independent.

Byrd and Hickman (1992) and Rosenstein and Wyatt (1990) argue that outside directors play an important part in protecting shareholders' wealth in situations where the interests of managers and outside owners diverge. In most cases, outside directors hold senior management positions in other large firms and they are familiar with the financial reporting process (Fama \& Jensen, 1983). This enables them to exert greater monitoring on firm financial reporting. Consistent with this argument, several studies find that firms with a high proportion of outside directors report more conservative earnings than firms with a low proportion of outside directors (Ahmed \& Duellman, 2007; Beekes, et al., 2004). To measure the influence and strength of non-executive directors, NONEXEC takes the value of 1 (good governance) if non-executive directors constitute more than half of the board, otherwise 0 . 
(iii) Board Independence

The importance of board independence in strengthening corporate governance has been advanced in the previous literature for at least two reasons. First, the existence of independent directors exerts a better monitoring of managers' decisions and activities by corporate boards (Fama, 1980). This is crucial to avoid an abuse of power by managers in order to maximise their own wealth (Roe, 1991). Fama and Jensen (1983) argue that a higher proportion of independent directors on corporate boards would result in more effective monitoring of boards and would limit managerial opportunism. Second, independent directors provide advice to corporate boards on strategic decisions, which may improve the firm's economic and financial performance (Fama, 1980). Realising the importance of independent directors in strengthening corporate governance, MCCG $(2000,2007)$ recommends that independent directors comprise at least one third of the corporate board.

With regard to earnings conservatism, independent directors have greater incentives to restrict managers' opportunistic actions, such as accelerating the recognition of good news in earnings or delaying the recognition of bad news. Given that independent directors do not share the benefits of opportunistic reporting, they risk their reputation in the professional labour market without gain from permitting opportunistic reporting (Fama, 1980). Therefore, in this study, board independence (BODIND) takes value 1 if the proportion of independent directors to the total number of directors is more than the median value, otherwise 0 . 
MCCG $(2000,2007)$ recommends separation of roles between the CEO and the chairman of the board of directors as such separation improves the board's monitoring function. According to Hermalin and Weisbach (2003), a board's effectiveness is heavily determined by board independence from the CEO. When a CEO has excessive power over board matters, reported earnings could easily be manipulated (Abdul Rahman \& Mohamed Ali, 2006). If the Chairman is appointed from among the independent directors, the CEO has no influence on director nomination and election, thus giving greater independence to the board (Jensen, 1993).

Chau and Gray (2010) argue that a chairman who is not independent has the freedom to manage a firm without constraint as he possesses a great amount of power and authority. According to Jensen (1993), the presence of chairman that is also the chief executive of the firm could override the advantage of having independent directors on the board and weaken the function of the board of directors. Since an independent chairman enhances the functions of the board with improved monitoring of the CEO and firm management, thus mitigating any tendency to delay the recognition of bad news. In this study, I assign a value 1 to INDCHRM if the chairman is an independent director, and 0 otherwise.

(v) Board Meetings

The number of board meetings held during the financial year is used as a 
proxy for the level of real monitoring and control exerted by directors (Vafeas, 1999). More frequent board meetings should indicate a more effective board because it suggests more active and close monitoring of managers to enable more timely corrective action if necessary. In this study, BODMEET takes the value 1 if the number of board meetings during the year is more than the median value, otherwise 0 .

(vi) Size of Audit Committee

Many empirical studies support the argument that the size of the audit committee positively affects earnings quality. A plausible explanation is that a larger audit committee has greater capacity and resources to perform its duties, including detection and curbing of earnings manipulation; hence having a larger committee results in a higher level of earnings quality. For example, Lin et al. (2006) find a negative association between the size of an audit committee and the occurrence of earnings restatements, implying that the size of an audit committee is a significant factor in mitigating earnings manipulation. In the Malaysian context, MCCG (2007) suggests that an audit committee should comprise at least three members. Following this recommendation, ACSIZE takes value 1 if the size of the audit committee is more than three, otherwise 0 .

(vii) Audit Committee Independence

Given that audit committee independence is crucial to exert effective monitoring of managers and to promote high standards of financial reporting, 
MCCG (2007) recommends that independent directors should dominate, that is, constitute more than half, of the audit committee. This recommendation is consistent with much of the empirical evidence of a positive association between audit committee independence and earnings quality. For example, Abbott et al. (2004) report that firms with an independent audit committee that meets at least four times a year have a lower number of financial restatements. In addition, Carcello and Neal (2000) find that financially distressed firms with independent audit committees are more likely to receive a going-concern qualification and are less likely to terminate their external auditors. This evidence implies that audit committee independence implies effective control over managers' financial reporting, by reducing opportunistic reporting by management. Hence, I predict that having an independent audit committee would result in more timely recognition of bad news. To measure audit committee independence, ACINDP takes the value 1 if all members of the audit committee are independent directors, otherwise 0 .

(viii) Number of Audit Committee Meetings

MCCG (2007) suggests that the audit committee should meet regularly. The code recommends that the meeting should be attended by the finance director, the head of internal audit, and the firm external auditor. Other board members may only attend the meeting upon invitation. The code states that the audit committee should have a meeting with the external auditor at least twice a year without the prescence of executive directors as to promote more independent discussions. 
Given that the frequency of the audit committee meetings represents the time devoted by the audit committee in monitoring firm management and financial affairs, prior studies use this variable to measure firm governance. Abbot et al. (2004) used a binary variable that takes value 1 if the audit committee held more than four meetings a year, otherwise 0 . Other studies, for example Bédard, Chtourou, and Courteau (2004) and David, Scott, and Irem (2007), measure the frequency of audit committee meetings based on the total number of meetings held in a year. In this study, ACMEET takes value 1 if the number of the audit committee meetings is more than the median value of the sample, and 0 otherwise.

(ix) Financial Expertise of Audit Committee

The appointment of audit committee members with a finance and/or accounting background helps to strengthen the functioning of the audit committee, particularly in monitoring and enhancing the quality of financial reporting. I identify the financial expertise of the audit committee based on the number of members of the audit committees with prior education and working experience in accounting, auditing, or finance, and holding a membership of any professional accounting body. The revised MCCG Code 2007 requires at least one audit committee member to be a member of an accounting association or body. The presence of a financial expert on the audit committee is expected to facilitate better monitoring of managers and to ensure a high quality of financial reporting. Thus, I assign value 1 for $A C E X P E R T$ if the audit committee has two or more members with financial expertise, and 0 otherwise. 
In general, big audit firms are expected to provide superior audit quality relative to small audit firms, for a number of reasons. Dopuch and Simunic (1980), for example, argue that investors associate Big Six (currently known as Big Four) auditors with higher quality audits because of observable characteristics such as specialized training, greater resources, and peer review. In addition, Big Four auditors have more invested in their reputation and face substantially higher litigation costs (Chung, et al., 2003).

These arguments are supported by significant empirical evidence. For instance, previous studies find that big audit firms have lesser earnings management (Becker, et al., 1998; Francis, Maydew, \& Sparks, 1999) and a higher earnings response coefficient (Teoh \& Wong, 1993). Furthermore, Gul, Tsui, and Dhaliwal (2006) find big audit firms are more effective in mitigating the adverse effect of non-audit services on the value relevance of earnings. With regard to earnings conservatism, Chung et al. (2003) find that Big Six auditors have stronger influence than do non-Big Six auditors in persuading their clients to adopt more conservative accounting, particularly where the clients' financial performance is worse than expected.

In term of size of audit firms in Malaysia, big firms constitute only around $1.1 \%$ of the total number of firms (Abu-Bakar \& Ahmad, 2009), but they audit around $60 \%$ of the listed firms (Arens, Loebbecke, Iskandar, Susela, \& Isa, 1999). Around $91.4 \%$ of Malaysian audit firms are small, with one to two 
partners; while medium-size audit firms, with three to eight partners, constitute $7.5 \%$ of audit firms (Abu-Bakar \& Ahmad, 2009). To measure the size of audit firms, I use a dummy variable of $B I G 4$ that takes value 1 if the observation is audited by a Big Four audit firm, otherwise 0 .

(xi) Auditor Industry Specialization

Auditor industry specialization is also argued playing a significant role in promoting earnings conservatism. Krishnan (2005a) find that industry specialists report more conservative earnings than non-specialists, suggesting that auditors' industry specialization moderates the tendency of the client to delay the recognition of economic losses in earnings. Furthermore, clients of industry specialists have significantly lower discretionary accruals than clients of non-specialist auditors (Krishnan, 2003). Consistent with prior literature (for e.g. Balsam, Krishnan, \& Yang, 2003; Krishnan, 2003), I identify industry specialists (SPECIALIST) using an industry leader approach. Under this approach, an industry specialist is the audit firm with the largest market share (based on the total sales of the companies audited) in the industry. I calculate industry market shares as follows:

$$
\text { Market Shares }_{i k}=\frac{\sum_{j=1}^{j i k} \text { Sales }_{i j k}}{\sum_{i=1}^{i k} \sum_{j=1}^{j i k} \text { Sales }_{i j k}}
$$

where Sales is total sales/revenues, and the numerator is the total sales of all $J i k$ clients of audit firm $i$ in industry $k$. The value of i represents the audit firms. I use four-digit GICS codes to identify industry categories. The 
denominator in the above model is the total sales for all clients of audit firm $i$ summed over all $k$ industries. To measure auditor industry specialisation, I use a dummy variable for SPECIALIST that takes value 1 if the observation is audited by an industry specialist and 0 otherwise.

\subsection{Regression Models}

This study employs ordinary least squares regression (OLS) to estimate the model used to examine the relationship between earnings conservatism and other variables such as a change in accounting standards, corporate governance and different types of ownership structure. The detailed applications of the model are discussed in the next subsections.

\subsubsection{Earnings Conservatism in Malaysia}

The first objective of this study is to examine the extent of earnings conservatism in Malaysia in 2003 to 2008. To test whether earnings are more timely in recognising bad news compared to good news, I employed Basu's (1997) asymmetric timeliness of earnings model, as stated below.

$$
E_{i t} / P_{i t-1}=\beta_{0}+\beta_{1} R E T_{i t}+\beta_{2} R D_{i t}+\beta_{3} R E T_{i t} * R D_{i t}+\varepsilon_{i t}
$$

where $E_{i t}$ is the earnings per share for firm $\mathrm{i}$ in fiscal year $\mathrm{t}$; $P_{i t-1}$ is the price per share at the beginning of the fiscal year; $R E T_{i t}$ is the annual return of firm $\mathrm{i}$ in fiscal year $\mathrm{t}$; $R D_{i t}$ is a dummy variable that equals 1 if $R E T_{i t}$ is negative, and 0 otherwise; and $\varepsilon_{i t}$ is the error term. 
The coefficient for the interaction variable of $R E T^{*} R D, \beta_{3}$, captures the incremental response to negative news relative to positive news. If a firm adopts conservative accounting practices, $\beta_{3}$ is expected to be positive. The ratio $\left(\beta_{1}+\beta_{3}\right) / \beta_{1}$ ratio measures the sensitivity of earnings to bad news relative to their sensitivity to good news. If a firm practices conservative accounting, $\left(\beta_{1}+\beta_{3}\right) / \beta_{1}$ is expected to be greater than one.

To ensure the robustness of the results, I employed various sensitivity tests including (1) Fama and MacBeth (1973) annual regression estimation; (2) control for industry and year effects; (3) control for firm specific factors; (4) restricting the observation to firms with Big Four auditors; (5) controlling for market return; (6) using announcement date returns; and (7) excluding firms with share price less than one Ringit (MYR). I also used the Basu time-series test of timeliness in loss recognition as an alternative measure for earnings conservatism. Detailed discussions of the robustness tests are provided.

\subsubsection{IFRS Adoption and Earnings Conservatism}

The second objective of this study is to examine whether there is a significant change in earnings conservatism after the adoption of IFRS in Malaysia. To conduct the test, I estimate equation (5.2), which tests the significance of the difference in earnings conservatism between pre- and post-IFRS adoption periods. For the main analysis, I examine two samples: (i) 1,042 firm-year observations for one-year pre- and post-IFRS adoption; and (ii) 2,084 firm-year observations for two-year pre- and post-IFRS adoption. For the additional tests, I limit the sample to firms with financial year-end dated 31 December. This test involves a sample 
of (i) 588 firm-year observations for one year pre- and post-IFRS adoption for firms with financial year end 31 December; and (ii) 1,176 firm-year observations for two year pre- and post-IFRS adoption.

$$
\begin{aligned}
E_{i t} / P_{i t-1}= & \beta_{0}+\beta_{1} R E T_{i t}+\beta_{2} R D_{i t}+\beta_{3} R E T_{i t} * R D_{i t}+\beta_{4} I F R S_{i t} \\
& +\beta_{5} I F R S_{i t} * R E T_{i t}+\beta_{6} I_{F R S_{i t} * R D_{i t}+\beta_{7} I F R S_{i t} * R E T_{i t} * R D_{i t}} \\
& +\varepsilon_{i t}
\end{aligned}
$$

where IFRS is a dummy variable that takes value 1 if the financial statements are prepared according to IFRS standards, and 0 otherwise; and the other variables are as defined above.

Equation (5.2) is an adaptation of the Basu (1997) model. I estimate this equation to allow the coefficients $\beta_{3}$ to differ across pre- and post-IFRS periods. This modification enables this study to test for differences in conservatism across these two periods. The coefficient $\beta_{3}$ measures the level of conservatism in the preIFRS period. The corresponding measure in the post-IFRS period is $\beta_{3}+\beta_{7}$. Therefore, the difference in conservatism between the pre- and post-IFRS periods is given by $\beta_{7}$. If the coefficient is positive (negative), it would indicate that financial statements prepared under the new accounting standards (IFRS) are more (less) conservative than under the old standards (MASB standards). The coefficient $\beta_{1}$ measures how quickly good news is reflected in reported earnings in the pre-IFRS period. The corresponding measure in the post-IFRS period is $\beta_{1}+$ $\beta_{5}$. Therefore, the difference between the pre- and post-IFRS periods with regard to earnings incorporating good news is given by $\beta_{5}$. 
To ensure the robustness of the results, various sensitivity analyses are conducted including (1) using different samples and time frames; (2) Fama and MacBeth (1973) annual regression estimation; (3) controlling for industry and year effects; (4) restricting the observation to firms with Big Four auditors; (5) concentrating on firms audited by an industry specialist; and (6) using the Basu (1997) timeseries test of timeliness in loss recognition as an alternative measure for earnings conservatism. Detailed discussions of the robustness tests are provided.

\subsubsection{Ownership Structure and Earnings Conservatism}

The third objective of this study is to examine whether earnings conservatism is influenced by ownership structure, in particular, family firms and state-controlled firms. I also include widely-held firms to enable comparison. In doing so, I estimate equation (5.1) for different types of firms. For robustness analysis, I employ various sensitivity tests including (1) Fama and MacBeth (1973) annual regression estimation; (2) controlling for industry and year effects; (3) alternative definition for family firms and government-linked companies; (4) employing a time-series test of timeliness in loss recognition as an alternative measure for earnings conservatism.

\subsubsection{Corporate Governance and Earnings Conservatism}

The fourth objective of this study is to examine the relationship between earnings conservatism and corporate governance. I estimate equations (5.3a) and (5.3b) to test the relationship between corporate governance and earnings conservatism. 


$$
\begin{aligned}
E_{i t} / P_{i t-1}= & \beta_{0}+\beta_{1} R E T_{i t}+\beta_{2} R D_{i t}+\beta_{3} R E T_{i t} * R D_{i t}+\beta_{4} C G I N D E X_{i t} \\
& +\beta_{5} C G I N D E X_{i t} * R E T_{i t}+\beta_{6} C G I N D E X_{i t} * R D_{i t} \\
& +\beta_{7} C G I N D E X_{i t} * R E T_{i t} * R D_{i t}+\varepsilon_{i t} \\
E_{i t} / P_{i t-1}= & \beta_{0}+\beta_{1} R E T_{i t}+\beta_{2} R D_{i t}+\beta_{3} R E T_{i t} * R D_{i t}+\beta_{4} D U M C G_{i t} \\
& +\beta_{5} D U M C G_{i t} * R E T_{i t}+\beta_{6} D U M C G_{i t} * R D_{i t} \\
& +\beta_{7} D U M C G_{i t} * R E T_{i t} * R D_{i t}+\varepsilon_{i t}
\end{aligned}
$$

where CGINDEX is an unweighted aggregate of 11 corporate governance variables; and DUMCG is a dummy variable that takes value 1 if CGINDEX is in the top third of the pooled sample, and 0 if CGINDEX is in the bottom third. The other variables are as defined above.

To ensure the robustness of the result, I perform several sensitivity tests such as (1) estimating the Fama and MacBeth (1973) annual regression; (2) controlling for industry and year effects; (3) using continuous variables rather than dummy variables; (4) employing a time-series test of timeliness in loss recognition as an alternative measure for earnings conservatism. Detailed discussions of the robustness tests are provided in the relevant section.

\subsection{Robustness Tests}

This study includes various robustness tests for every hypothesis. In this section, I provide the general sensitivity tests that were conducted for all the hypotheses. Sensitivity analyses which are unique to a particular hypothesis are discussed separately in the data analysis section. 


\subsubsection{Alternative Measure for Earnings Conservatism}

As noted in Section 2.4.1, the Basu asymmetric timeliness of earnings measure is subject to a number of criticisms. However, as also noted, Ryan (2006) concludes that asymmetric timeliness of earnings is still the best measure of earnings conservatism. Nevertheles, Ryan encourages the use of multiple measures. To ameliorate the above concerns, I also employed the time-series test of timeliness in loss recognition, equation (1.2), as described in Section 2.4.2.

Khan and Watts (2009) estimate a firm-year measure for earnings conservatism (C_Score) by allowing the coefficient for $R E T^{*} R D$ in the Basu (1997) asymmetric timeliness of earnings model to vary across firms and over time. An explanation of this model is provided in Section 2.4.5 above. Despite the robust estimation of C_Score in the United States, Khan and Watts (2009) suggest several caveats on the application of this model. First, the development of $C \_$Score is motivated from the four Watts (2003a) determinants of conservatism in the US. Hence, for nonUS samples, this may not be an appropriate measure since the institutional features differ from those in the United States. In certain countries, there are weak legal enforcement regimes, in which contracts are more easily vitiated and litigation (and litigation liabilities) more easily circumvented. Second, the C_Score has not been developed by solving for equilibrium conditions in an analytical model, thus it is not necessarily the optimal measure of conservatism. Finally, there are possibilities of a correlated omitted variable problem if C_Score is used as an independent variable in a multiple regression. Considering the caveats made by Khan and Watts (2009), I do not employ the firm-year measure. 


\subsubsection{Fama and MacBeth (1973) Annual Regression}

I use the Fama and MacBeth (1973) annual regression estimate technique to cope with potential cross-sectional dependence problems, particularly since the data are concentrated over a small number of years. OLS standards errors from pooled regressions are biased and result in incorrect inferences in the presence of crosssectional dependence (Bernard, 1989). This problem is especially acute in regressions using annual stock returns because the common time-series variation in observations drawn from the same year induces cross-sectional dependence, and biases the pooled cross-sectional standard errors (Basu, 1997). Estimating the regression separately for each year partially controls this problem. The coefficients for the parameters are obtained as the simple average from the crosssectional regression. The t-statistics are the ratios of the mean estimated coefficients to the standard deviation of the distribution of the annual estimated slope coefficients, divided by the square root of the number of years.

\subsubsection{Control for Firm-Specific Variables}

To ascertain the validity of the results, this study controls for firm-specific variables, particularly firm size, leverage and market to book ratio. These variables influence Watts' explanations for conservatism, including contracting, litigation, taxation and regulation (Khan \& Watts, 2009). Thus, in this study I include these variables as controls. 
This study controls for firm size (SIZE) as it affects the demand for conservatism. Given that larger firms are more mature and have richer information environments, the information asymmetry and the overall uncertainty of the business is low, which causes lower contracting demands for conservatism (Khan \& Watts, 2009). Large firms also have lower information asymmetry than small firms, though their business operations are more complex, with many segments (Easley, Hvidkjaer, \& O'Hara, 2002). On the other hand, larger firms have higher litigation demand for conservatism because these firms attract more litigation due to higher expected recovery costs. Khan and Watts (2009) argue that larger firms have lower taxation demand for conservatism since they have more divisions and segments, which permit the aggregation of gains with losses across divisions, and greater flexibility to smooth (or defer) high earnings, hence reducing the present value of their tax liability. The study measures size as the natural logarithm of a firm's assets.

\section{(ii) Leverage}

This study controls for firm leverage ( $L E V)$ because firms with higher leverage have higher contracting, litigation, and taxation demands for conservatism (Khan \& Watts, 2009). Furthemore, the potential for agency conflicts between shareholders and debtholders is high when leverage is high (Barclay \& Smith, 1995; Jensen \& Meckling, 1976; Myers, 1977). In addition, high-leverage firms have a higher likelihood of financial distress and a higher 
likelihood of being sued, thus generating greater demand for conservatism. High-leveraged firms are more likely to be mature firms with higher taxable earnings thereby generating a higher taxation demand for conservatism (Khan \& Watts, 2009). In short, high-leverage firms are more likely to have a higher demand for conservatism as conservatism triggers debt covenant violations in a timely fashion and constrains opportunistic diversion of resources (Khan \& Watts, 2009). The study measures leverage as the ratio of total debt to total assets.

\section{(iii) Market to Book Ratio}

Finally, the study controls for the market to book ratio $(M T B)$, a proxy for growth options. This is crucial because firms with high growth options are more likely to have a higher probability of litigation, lower taxable earnings, and be free of regulation (Khan \& Watts, 2009). Given that growth options are positively linked to agency costs (Smith \& Watts, 1992), firms with a high levels of growth options (high MTB) would demand higher conservatism. Furthermore, high $M T B$ firms have a higher litigation demand for conservatism because their stock returns are more volatile, since a large proportion of their market value is due to risky growth options (Khan \& Watts, 2009). However, firms with high MTB are less likely to be regulated, and thus have a lower regulation demand for conservatism (Khan \& Watts, 2009).

Application of earnings conservatism, or the asymmetric verification 
requirements for gains versus losses, generates cumulative understatement of net assets relative to market values; hence it results in higher MTB. Roychowdury and Watts (2007), however, state that the positive relationship between conservatism and $M T B$ is not observed empirically due to the "buffer problem'. They argue that in a short-horizon period, beginning MTB is negatively correlated with conservatism flows due to prior unrecognised increases in asset values reducing the necessity to recognise asset value losses. Given that ending $M T B$ is a function of beginning $M T B$, this induces a negative relation between ending MTB and conservatism at the annual horizon (Roychowdury \& Watts, 2007). However, for longer horizons (three years or more), Roychowdhury and Watts (2007) find the effect of the beginning MTB is minimised and ending $M T B$ is positively correlated with conservatism.

\subsection{Conclusions}

The present chapter has described the research design and method adopted for the study. The sample is described, and the chapter then discussed the measues for the variables used in the study. Finally, the chapter explains the regression models employed in testing the hypotheses. The next chapter presents the data analysis and findings of the study. 


\section{CHAPTER SIX \\ EMPIRICAL ANALYSIS}

\subsection{Introduction}

This chapter presents and discusses the findings of this study. The chapter is organised as follows. Section 6.2 presents the descriptive statistics for the continuous and dichotomous variables, and the correlation matrix. It also provides a review of the econometric issues. The results for the test of Hypothesis 1 on earnings conservatism following the institutional reforms discussed in Chapter 3 are reported in Section 6.3. Section 6.4 presents the results for the test of Hypothesis 2 on the effect of IFRS adoption on earnings conservatism. The results for the test of Hypothesis 3 on how the level of earnings conservatism varies across different types of ownership structure are reported in Section 6.5. Section 6.6 presents the findings for the test of hypothesis 4 on the relationship between corporate governance and earnings conservatism. Each section includes the relevant sensitivity analyses. Finally, Section 6.7 summarises the findings.

\subsection{Descriptive Statistics and Correlation Analysis}

\subsubsection{Descriptive Statistics}

Table 6.1 provides the characteristics of the sample. Panel A shows the breakdown of the sample according to the financial year end. More than half $(56.46 \%)$ of the sample has a financial year end of 31 December, while $12.35 \%$ and $13.63 \%$ of the sample have a financial year end of 31 March and 30 June, 
respectively. Only a few firms close their accounts on months other than December, March and June.

Table 6.1

Sample characteristics

Panel A: Sample according to financial year end

\begin{tabular}{lrr}
\hline Month & $\mathrm{N}$ & Pct $(\%)$ \\
\hline January & 124 & 3.97 \\
February & 12 & 0.38 \\
March & 386 & 12.35 \\
April & 90 & 2.88 \\
May & 73 & 2.34 \\
June & 426 & 13.63 \\
July & 53 & 1.70 \\
August & 54 & 1.73 \\
September & 72 & 2.30 \\
October & 53 & 1.70 \\
November & 18 & 0.58 \\
December & 1,765 & 56.46 \\
\hline Total & 3,126 & 100.00 \\
\hline
\end{tabular}

Panel B: Sample according to industry classifications

\begin{tabular}{llrr}
\hline Sector & Symbol & $\mathrm{N}$ & Pct $(\%)$ \\
\hline Construction & CSTRUCT & 33 & 6.33 \\
Consumer Product & CONS & 87 & 16.70 \\
Hotel & HOTEL & 4 & 0.77 \\
IPC & IPC & 5 & 0.96 \\
Industrial Product & IPROD & 169 & 32.44 \\
Plantation & PLANT & 33 & 6.33 \\
Property & PROP & 67 & 12.86 \\
Technology & TECH & 17 & 3.26 \\
Trading/Services & TDG & 106 & 20.35 \\
\hline Total & & 521 & 100.00 \\
\hline
\end{tabular}

Panel C: Sample according to ownership structure

\begin{tabular}{lrr}
\hline Ownership & $\mathrm{N}$ & Pct (\%) \\
\hline Family firms & 1,770 & 56.62 \\
State-controlled firms & 234 & 7.49 \\
Widely-held firms & 1,122 & 35.89 \\
\hline Total & 3,126 & 100.00 \\
\hline
\end{tabular}


Panel D: Sample according to auditor size

\begin{tabular}{lrr}
\hline Auditor & $\mathrm{N}$ & Pct (\%) \\
\hline Big Four & 2063 & 65.99 \\
Non-Big Four & 1063 & 34.01 \\
\hline Total & 3,126 & 100.00 \\
\hline & & \\
\hline & $\mathrm{N}$ & Pct (\%) \\
\hline Auditor & 854 & 27.32 \\
\hline Industry specialist & 2272 & 72.68 \\
$\quad$ Non-industry specialist & 3,126 & 100.00 \\
\hline Total & &
\end{tabular}

Panel B of Table 6.1 shows the classification of the sample according to industry. Almost one third of the sample $(32.44 \%)$ comes from the industrial product sector, while the consumer product sector provides $16.70 \%$ of the sample. This is consistent with the general economy of Malaysia, where manufacturing sectors dominate the economy. The trading/services and property sectors are also significant in the sample, with 106 firms (20.35\%) and 67 firms (12.86\%) respectively. Thirty-three firms $(6.33 \%)$ in the sample come from the construction sector. The plantation sector has only 33 firms $(6.33 \%)$ in the total sample, which is quite a small proportion compared to the economic contribution of that sector and its importance to the Malaysian economy. This phenomenon is due to the large number of mergers among plantation firms, including firms under the control of the Malaysian government.

Panel C provides a breakdown of the ownership structure of the firms in the sample. More than half of the sample (56.62\%) are family firms, followed by widely-held firms (35.89\%) and state-controlled firms (7.49\%). Even though the number of state-controlled firms is small, state-controlled firms constitute around 
$36 \%$ of the total market capitalisation (PCG, 2005), indicating there is significant influence by state-controlled firms in the Malaysian economy. Panel D and Panel E denote firm classification according to auditor size and specialisation. The Big Four auditors audited almost two-thirds (65.99\%) of the sample, while the remaining firm-year observations (34.01\%) were audited by non-Big Four auditors. An industry specialist audited more than a quarter $(27.32 \%)$ of the total population, while the remaining firm-year observations $(72.68 \%)$ were audited by non-specialist auditors.

Table 6.2

Descriptive statistics

\begin{tabular}{lrrrrrrr}
\hline Variable & Mean & SD & Min & Q1 & Median & Q3 & Max \\
\hline E/P & 0.044 & 0.286 & -1.655 & 0.007 & 0.070 & 0.135 & 1.197 \\
RET & 0.179 & 0.824 & -0.746 & -0.250 & -0.005 & 0.305 & 5.370 \\
SIZE & 8.561 & 0.580 & 7.465 & 8.132 & 8.485 & 8.900 & 10.313 \\
LEV & 0.411 & 0.209 & 0.043 & 0.249 & 0.405 & 0.560 & 0.899 \\
MTB & 1.025 & 0.822 & 0.152 & 0.495 & 0.771 & 1.253 & 4.205 \\
BODSIZE & 7.444 & 1.841 & 3.000 & 6.000 & 7.000 & 9.000 & 15.000 \\
NONEXEC & 0.621 & 0.172 & 0.200 & 0.500 & 0.600 & 0.750 & 1.000 \\
BODIND & 0.420 & 0.108 & 0.143 & 0.333 & 0.400 & 0.500 & 0.857 \\
BODMEET & 5.341 & 2.067 & 0.000 & 4.000 & 5.000 & 6.000 & 30.000 \\
ACSIZE & 3.457 & 0.677 & 2.000 & 3.000 & 3.000 & 4.000 & 10.000 \\
ACIND & 0.741 & 0.122 & 0.250 & 0.670 & 0.670 & 0.750 & 1.000 \\
ACMEET & 4.841 & 1.187 & 1.000 & 4.000 & 5.000 & 5.000 & 21.000 \\
ACEEXPERT & 0.370 & 0.182 & 0.000 & 0.250 & 0.333 & 0.400 & 1.000 \\
CGINDEX & 0.452 & 0.154 & 0.000 & 0.364 & 0.455 & 0.545 & 1.000 \\
\hline NIIII
\end{tabular}

Note: All variables are truncated at $1 \%$ level (upper and bottom).

Table 6.2 summarises the descriptive statistics for the variables included in this study. For earnings yield $(E / P)$, the mean is 0.044 with a maximum (minimum) value of $1.197(-1.655)$. The stock return (RET) has a mean of 0.179 , while the maximum (minimum) value is $5.370(-0.746)$. Firm size $(S I Z E)$, measured using the natural logarithm of total assets, ranges between 7.465 and 10.313 , with a 
mean of 8.561 . For leverage $(L E V)$, the ratio of total debt to total assets is between 0.043 and 0.899 , with a mean value of 0.411 . The $M T B$ ratio ranges between 0.152 and 4.205 with a mean value of 1.025 . The mean value for board size (BODSIZE) is 7.444; board size ranges between 3 to 15 directors. For board composition, on average $62.1 \%$ of board members are non-executive directors (NONEXEC) and $42.0 \%$ are independent non-executive directors (BODIND), showing a high degree of compliance with the MCCG (2000) recommendations. For board meetings (BODMEET), on average five meetings were held every financial year, with a range between 0 and 30 meetings. In terms of the audit committee's characteristics, the committee has on average 3.457 members (ACSIZE), of whom $74.1 \%$ are independent non-executive directors (ACIND); the committee held an average of 4.841 meetings per financial year (ACMEET), and $37 \%$ of the audit committee members have an accounting and/or finance background and are members of professional accounting bodies (ACEXPERT). Finally, the unweighted corporate governance index (CGINDEX) is on average 0.452 , with a range between 0.00 and 1.00 .

\subsubsection{Correlation Analysis}

A correlation analysis was performed to test the strength of the relationships among the variables used in this study. Table 6.3 provides Pearson and Spearman correlations among all variables. In general, the analysis shows no suggestion of collinearity between the variables.

As reported in Table 6.3, earnings yield $(E / P)$ and stock returns (RET) is positively correlated at the $1 \%$ level $($ Pearson $=0.305 ;$ Spearman $=0.405)$, which 
is consistent with the theory on earnings-return relationship. Board size $(B O D S I Z E)$ and audit committee size (ACSIZE) are positively correlated with earnings yield $(\mathrm{E} / P)$, while board independence (BODIND), board meeting (BODMEET), and audit committee meeting (ACMEET) are negatively correlated with earnings yield $(E / P)$. The correlation between stock returns $(R E T)$ and other variables is low, with a Spearman correlation value between -0.050 and 0.073 and a Pearson correlation value between -0.038 and 0.043 .

All variables other than earnings yield $(E / P)$ and $(R E T)$ are significantly correlated with the corporate governance index (CGINDEX). This is consistent with the fact that the variables are used to develop the corporate governance score. The proportion of non-executive directors (NONEXEC) and board independence (BODIND) have moderate correlation with the corporate governance score. The Pearson (Spearman) correlation between the proportion of non-executive directors $(N O N E X E C)$ and corporate governance index (CGINDEX) is $0.523(0.523)$, while the Pearson (Spearman) correlation between board independence (BODIND) and corporate governance index is $0.477(0.497)$. The correlations for other variables fall between 0.368 and 0.114 .

Overall, all variables have a correlation of less than 0.50 , except for the correlation between CGINDEX and NONEXEC. The results from Table 6.3 suggest there is no serious multi-collinearity among the independent variables, since none of the correlations exceed 0.7 (Pallant, 2007). 


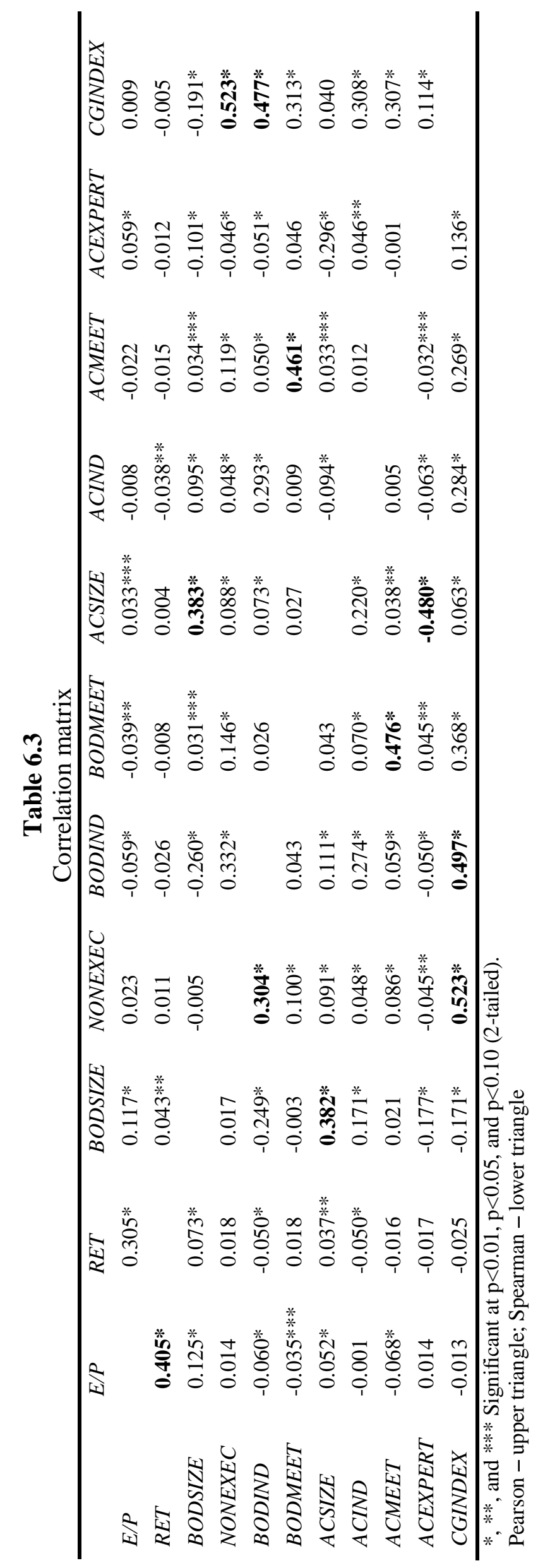




\subsubsection{Econometric Issues}

This section discusses several potential econometric issues associated with the estimation of the earnings conservatism model. The issues include outliers, normality, heteroscedasticity and multicollinearity assumptions. These issues are related to the procedure for the estimation of the parameters of the ordinary least squares (OLS) regression. To ensure that the interpretation of the regression estimates is valid, the assumptions about the variables and the error term of OLS must be satisfied.

Firstly, I examined the issue of outliers or unusual observations. It is crucial to consider the undue influence of outliers because outliers can distort the interpretation of data and may lead to incorrect inferences. Some studies delete outliers (e.g. Ball \& Shivakumar, 2006; Basu, 1997), while other studies truncate the outliers (e.g. García Lara \& Mora, 2004). In this study, I truncated the upper and lower $1 \%$ of extreme value.

Table 6.4 summarises the basic statistics for stock return (RET) and earnings yield (E/P) truncated at $0 \%$ and $1 \%$. The $0 \%$ truncation represents the unadjusted data that is, no truncation. The truncation at the $1 \%$ level indicates that the upper and lower $1 \%$ of extreme values are not eliminated but drawn at the tail of the distribution. For example, in the $1 \%$ level of truncation of stock return (RET), $98 \%$ of the values range from -0.746 to 5.370 . Furthermore the extreme lower $1 \%$ of the value range is from -0.937 to -0.746 and the extreme upper $1 \%$ of the value range is from 5.370 to 37.775 . Truncation at the $1 \%$ level forces the extreme lower firm-year observations to assume the value of -0.746 (at $1 \%$ lower) and the 
extreme upper firm-year observations to assume the value of 5.370 (at $1 \%$ upper). Thus, the extreme values are drawn with the upper and lower tails of the distribution.

Table 6.4

Analysis for unusual observation and normality

\begin{tabular}{|c|c|c|c|c|}
\hline \multirow{2}{*}{$\begin{array}{l}\text { Variable } \\
\text { Truncation Level }\end{array}$} & \multicolumn{2}{|c|}{ Stock Return (RET) } & \multicolumn{2}{|c|}{ Earnings Yield $(E / P)$} \\
\hline & 0 Percent & 1 Percent & 0 Percent & 1 Percent \\
\hline Min & -0.937 & -0.746 & -14.315 & -1.655 \\
\hline Махітит & 37.775 & 5.370 & 10.123 & 1.197 \\
\hline Mean & 0.245 & 0.179 & 0.037 & 0.044 \\
\hline Standard Deviation & 1.550 & 0.824 & 0.600 & 0.286 \\
\hline Skewness & 12.442 & 3.522 & -7.437 & -1.887 \\
\hline Kurtosis & 223.054 & 19.494 & 244.910 & 15.483 \\
\hline $\begin{array}{l}\text { Kolmogorov-Smirnov test } \\
(p \text {-value })\end{array}$ & $(\mathrm{p}<0.01)$ & $(\mathrm{p}<0.01)$ & $(\mathrm{p}<0.01)$ & $(\mathrm{p}<0.01)$ \\
\hline $\begin{array}{l}\text { Skewness/Kurtosis tests for } \\
\text { Normality (p-value) }\end{array}$ & $(\mathrm{p}<0.01)$ & $(\mathrm{p}<0.01)$ & $(p<0.01)$ & $(\mathrm{p}<0.01)$ \\
\hline
\end{tabular}

The measure of skewness indicates the symmetry in the data. As reported in Table 6.4, I find that the measure of skewness decreases as the level of truncation increases. For example, the level of skewness at the $0 \%$ truncation level for stock returns equals $(R E T) 12.442$, but it decreases to 3.522 at the $1 \%$ truncation level. For earnings yield $(E / P)$, the skewness at the $0 \%$ truncation level is -7.437 , decreases to -1.887 at the $1 \%$ truncation level. These results of the skewness of earnings yield and stock returns are consistent with evidence of conservatism. As reported in previous studies, for example Kwon, Yin and Han (2006), negative skewness of earnings is evidence of earnings conservatism.

Kurtosis statistics indicate the extent to which the distribution departs from a bell shape or normal curve due to fat tails. I find that the measure of kurtosis is very 
high at the $0 \%$ truncation level but decreases at the higher truncation level. The analysis presented in Table 6.4 shows that the level of kurtosis for stock return is 223.054 at the $0 \%$ truncation level, and decreases substantially to 19.494 at the $1 \%$ truncation level. The level of kurtosis for the earnings yield variable acts in similar fashion. At the $0 \%$ truncation level, the kurtosis statistic for earnings yield is equal to 244.910 and then decreases to 15.483 at the $1 \%$ truncation level.

Secondly, I tested the assumption of normality for the dependent and independent variables by conducting a Kolmogorov-Smirnov test and Skewness/Kurtosis tests for normality. In addition, I drew the P-P Plots for Residuals and Dotplots of Residuals. Testing for normality (i.e., skewness and kurtosis) is important because it tells the researcher about the distribution of the sample data used for statistical inference. Non-normal data may lead to incorrect conclusions in inferential statistical analyses or may have a bias effect on correlation coefficients (Schroeder, Sjoquist, \& Stephan, 1986).

The results in Table 6.4 show that the p-values for the Kolmogorov-Smirnov test and Skewness/Kurtosis tests for normality are less than 0.01 for both variables, showing a non-normally distributed population. Figure 6.1 and Figure 6.2 also depict the problem of normality. However, this problem is common in most market-based accounting studies. These studies find that earnings and stock returns data are skewed to the right, which indicates larger positive values than negative values. Hair, Black, Babin, Anderson, and Tatham (2006) contend that researchers can be less concerned with non-normal variables as the sample size become larger. In this study, the sample, with more than 3,100 observations, can 
be considered large.

Figure 6.1

P-P Plots for residuals

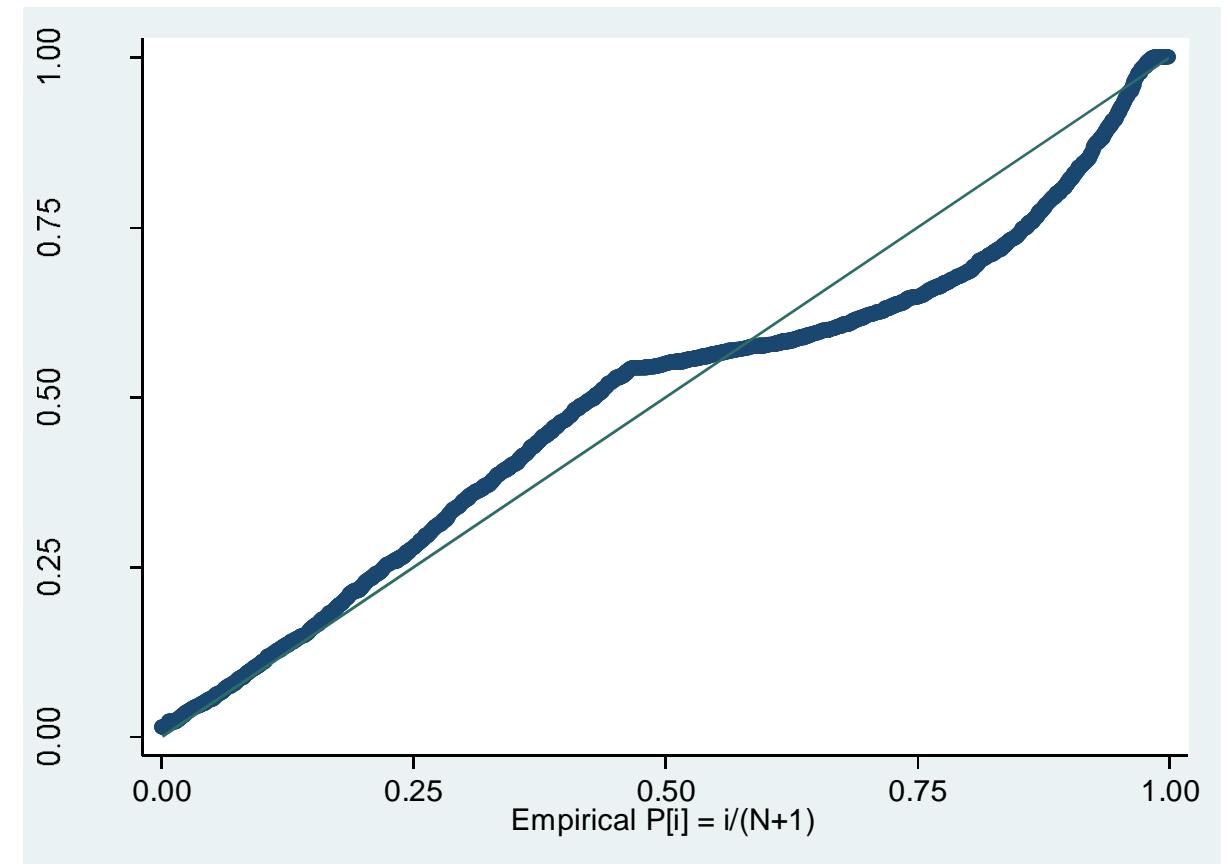

Figure 6.2

Dotplots of residuals

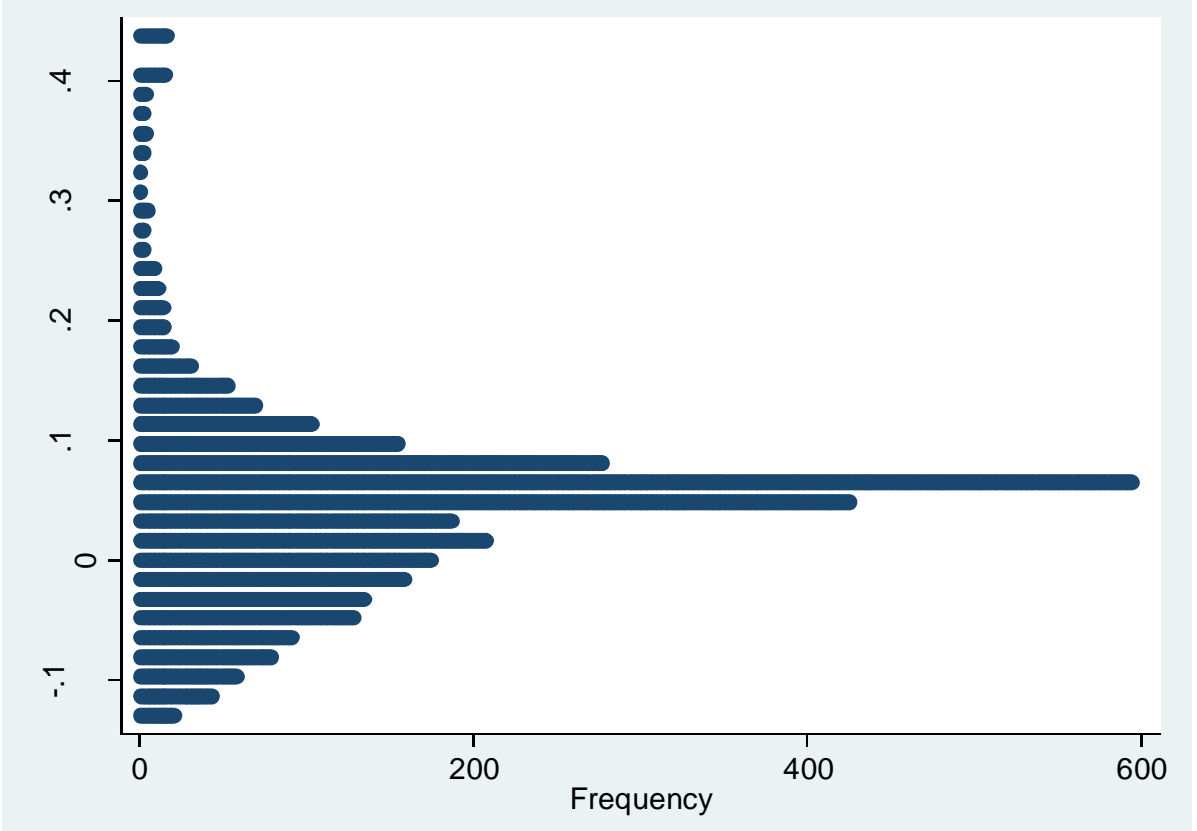


Thirdly, I tested for heteroscedasticity when estimating the regression model by OLS. The problem of heteroscedastic disturbances arises from the fact that large (small) firms tend to produce large (small) disturbances. Gujarati (2004) argued that if heteroscedasticity is present, then the OLS estimators no longer exhibit minimum variance among all linear unbiased estimators.

I conducted a Breusch-Pagan/Cook-Weisberg test and White's test on various samples to test the heteroscedasticity assumption. The results for both diagnostic tests are presented in Table 6.5. The results show that the p-values for the Breusch-Pagan/Cook-Weisberg test and White's test for heteroscedasticity are less than 0.01 for both variables, indicating a problem of heteroscedasticity. To overcome this problem, all regression estimates were reported using t-statistics with White (1980) adjustment to correct for the possibility of heteroscedasticity.

Table 6.5

Diagnostic tests for Heteroscedasticity assumption

\begin{tabular}{lcccc}
\hline \multicolumn{1}{c}{ Sample } & \multicolumn{2}{c}{ Breusch-Pagan/ } & \multicolumn{2}{c}{ White's test } \\
& Cook-Weisberg test & \multicolumn{2}{c}{ p-value } \\
\hline Pooled sample & 242.73 & 0.000 & 65.2 & 0.000 \\
Family Firms & 117.09 & 0.000 & 72.14 & 0.000 \\
State-Controlled firms & 8.65 & 0.000 & 9.5 & 0.000 \\
Widely-Held firms & 50.68 & 0.000 & 32.61 & 0.000 \\
\hline
\end{tabular}

Finally, I did not find any suggestion of multicollinearity among the regressors included in the regression model. Gujarati (2004) states that the term 'multicollinearity' is used where the variables are intercorrelated (perfect or nonperfect). This issue was discussed in the previous section. The Spearman and Pearson correlation reported in Table 6.3 do not indicate any serious collinearity 
issues between the variables.

\subsection{Earnings Conservatism Following the Reforms}

\subsubsection{Introduction}

As noted earlier, the first objective of this study is to examine earnings conservatism in Malaysian financial reporting following the institutional reforms discussed in Chapter 3, particularly in respect of corporate governance and financial reporting. The following section (Section 6.3.2) presents the main empirical results, while Section 6.3.3 reports the results from the robustness analyses. Section 6.3.4 discusses the overall results for the first objective.

\subsubsection{Main Analysis: Earnings Conservatism in Malaysia}

This study employs the Basu (1997) reverse earnings-return regression to examine earnings conservatism, by the asymmetric timeliness of earnings measure. To provide greater insight into the differences in timeliness of earnings between good news and bad news samples, I partitioned the sample into good news and bad news subsamples, and then estimated the basic earnings-return regression to capture the timeliness of earnings in both samples. The regression estimates are reported in Column 1 and Column 2 of Table 6.6. I then estimated equation (5.1), the Basu (1997) reverse earnings-return regression, to test for significant difference between the asymmetric timeliness of earnings for the two subsamples. The regression estimates are summarised in Column 3. In Column 4, the regression estimates of Ball et al. (2003) on earnings conservatism in Malaysia 
prior to the 1997 financial crisis are presented for comparison purposes.

The results reported in Column 1 and Column 2 of Table 6.6 show that the coefficients for RET in both good news and bad news subsamples are positive and significant at a $1 \%$ level. These results show evidence of the timeliness of earnings in response to economic news. The coefficient for RET in the good news sample is 0.071 , which is lower than the coefficient for RET in the bad news sample, which is 0.260 . These results indicate a higher timeliness of earnings in relation to bad news relative to good news.

\section{Table 6.6}

Asymmetric timeliness of earnings

\begin{tabular}{|c|c|c|c|c|c|c|c|c|}
\hline \multirow{2}{*}{ Sample } & \multicolumn{2}{|c|}{ Good News } & \multicolumn{2}{|c|}{ Bad News } & \multicolumn{2}{|c|}{ Pooled } & \multicolumn{2}{|c|}{ Ball et al. (2003) } \\
\hline & Coeff & $t$-stat & Coeff & $t$-stat & Coeff & $t$-stat & Coeff & $t$-stat \\
\hline Intercept & $0.052 *$ & $(5.900)$ & $0.062 *$ & $(5.234)$ & $0.052 *$ & $(5.900)$ & Not rep & rted \\
\hline$R E T$ & $0.071 *$ & (5.010) & $0.260 *$ & (7.387) & $0.071^{*}$ & (5.010) & Not rep & rted \\
\hline$R D$ & & & & & 0.009 & $(0.637)$ & $0.01 * *$ & (2.44) \\
\hline$R E T * R D$ & & & & & $0.189 *$ & (4.975) & 0.00 & $(0.20)$ \\
\hline $\operatorname{Adj} . R^{2}$ & 0.05 & & 0.03 & & 0.08 & & 0.09 & \\
\hline$N$ & 1558 & & 1568 & & 3126 & & 768 & \\
\hline$F$-stat & 25.100 & & 54.575 & & 59.249 & & Not rep & rted \\
\hline
\end{tabular}

Model: $E_{i t} / P_{i t-1}=\beta_{0}+\beta_{1} R E T_{i t}+\beta_{2} R D_{i t}+\beta_{3} R E T_{i t} * R D_{i t}+\varepsilon_{i t}$

The sample comprises 3,126 firm-year observations from firms in Bursa Malaysia during 20032008. The reported $t$-statistics are in parentheses and adjusted for heteroscedasticity (White, 1980). Asterisks denote statistical significance at the $1 \%(*), 5 \%(* *)$, or $10 \%(* * *)$ level, respectively. Variable definitions: $E_{i t}$ is the earnings per share for firm i in fiscal year $\mathrm{t} ; P_{i t-1}$ is the price per share at the beginning of the fiscal year; $R E T_{i t}$ is the annual return of firm i in fiscal year $\mathrm{t} ; R D_{i t}$ is a dummy variable that equals 1 if $R E T_{i t}$ is negative, and 0 otherwise; and $\varepsilon_{i t}$ is the error term.

Column 3 reports the regression estimates from the Basu (1997) model, which tests whether there is significant difference between the timeliness of earnings for the good news and bad news subsamples as reported in Column 1 and Column 2. The result shows that the coefficient for $R E T^{*} R D, \beta_{3}$, is positive (0.189) and significant at the $1 \%$ level, implying that earnings reflect bad news in a more 
timely manner than they reflect good news. The estimation results also show that $\beta_{1}+\beta_{3}>\beta_{1}$, equivalent to $(0.071+0.189)>0.071$, indicates evidence of earnings conservatism. The value of $\left(\beta_{1}+\beta_{3}\right) / \beta_{1}$ is 3.66 , showing that earnings are three times more sensitive to bad news than to good news. With respect to the validity of the models, all $F$-statistics are significant at the $1 \%$ level, while the adjusted- $R^{2}$ for equation (5.1) is 8\%, but is slightly lower than the result in Ball et al. (2003). For the good news and bad news subsamples, the adjusted- $R^{2}$ s are $5 \%$ and $3 \%$.

To illustrate the evidence of earnings conservatism, I exhibit the relationship between stock returns and accounting earnings in Figure 6.3. This figure depicts all observations in the sample, with separate regression lines for good news and bad news samples. The slope directions for both lines show a positive relationship between stock return and earnings. As predicted, the slope for bad news in the second $(\mathrm{Q} 2)$ and third quadrants $(\mathrm{Q} 3)$ are higher than the slope coefficient for good news in the first quadrant $(\mathrm{Q} 1)$, showing earnings are more sensitive to bad news relative to good news. This figure depicts evidence of earnings conservatism, in which earnings anticipate economic losses more quickly than economic gains, so that stock prices reflect bad news in the form of contemporaneous market losses earlier than good news in the form of market gains.

The findings as reported in Table 6.6 and illustrated in Figure 6.3 document evidence on earnings conservatism in Malaysia. Regression estimates for 3,126 firm-year observations, in the period following the institutional reforms, show that negative news is registered in earnings more promptly than positive news; hence 
providing evidence to reject the first null hypothesis.

Figure 6.3

Asymmetric timeliness of earnings

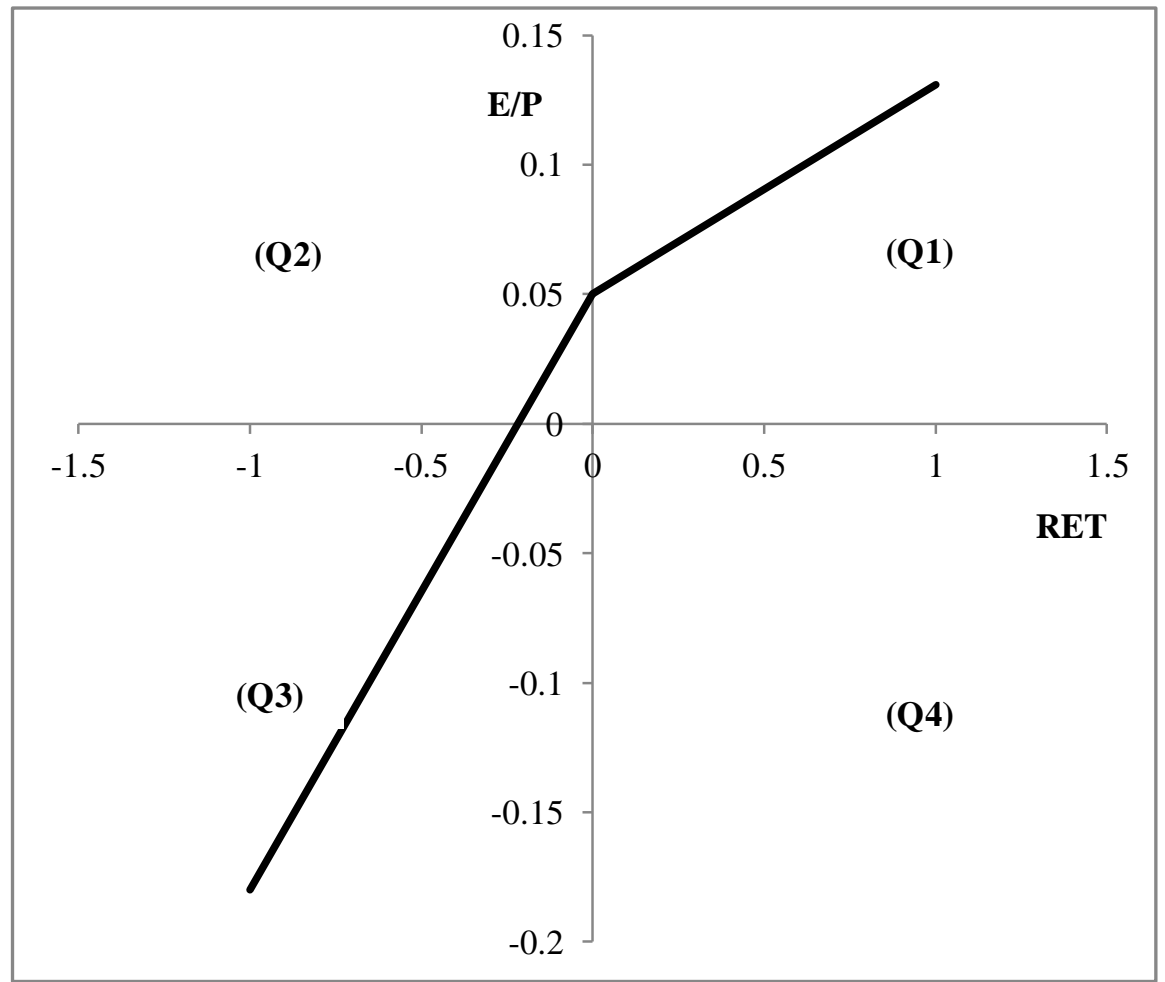

This result differs from the result documented by Ball et al. (2003) for 768 firmyear observations from 1984 to 1996 . Ball et al. Find that the coefficient for $R E T^{*} R D$ is 0.00 and not significant ( $\left.>>0.10\right)$, showing no evidence for earnings conservatism, or no significant difference in the timeliness of earnings between good news and bad news. In an environment of weak institutional structure, Ball et al. (2003) suggest that preparers of financial reports have less incentive to report high quality earnings, even though the accounting standards are of high quality. Complementing Ball et al. (2003) and Bushman and Piotroski (2006), this study shows evidence of earnings conservatism in the period following the institutional reforms, implying that managers and preparers of financial reports 
have higher expectations to meet in reporting and thus report earnings conservatively. In short, our results suggest that the strong institutional factors give greater incentives for managers to report earnings conservatively.

\subsubsection{Sensitivity Analysis}

This section reports the results from sensitivity tests on the findings in Section 6.3.2. Eight sensitivity analyses were conducted: Fama and MacBeth (1973) annual regression estimation (Section 6.3.3.1), controlling for industry and year effects (Section 6.3.3.2), controlling for firm-specific variables (Section 6.3.3.3), restricting the sample to firms with Big Four auditors (Section 6.3.3.4), controlling for market return (Section 6.3.3.5), employing an alternative measure of economic news using inter-announcement period stock returns (Section 6.3.3.6), excluding observation with share prices less than MYR 1.00 (Section 6.3.3.7), and employing the time-series test of timeliness in loss recognition model as an alternative measure of earnings conservatism (Section 6.3.3.8).

\subsubsection{Fama and MacBeth (1973) Annual Regression}

I estimated a Fama and MacBeth (1973) annual regression to address the possibility of the earlier results being influenced by cross-sectional dependence problems. $^{25}$ The regression estimates for a good news sample, a bad news sample and a pooled sample using Fama and MacBeth (1973) are reported in Table 6.7.

\footnotetext{
${ }^{25}$ The results obtained from estimating the Fama and MacBeth (1973) annual regression should be interpreted with caution since it assumes that the relationship between variables is stationary over time. Basu et al. (2001) raises concern about the results from this analysis when applied in capitalmarket-based accounting research.
} 
Table 6.7

Asymmetric timeliness of earnings: Fama and MacBeth (1973) annual regression

\begin{tabular}{lcccccc}
\hline \multirow{2}{*}{ Sample } & \multicolumn{2}{c}{ Good News } & \multicolumn{2}{c}{ Bad News } & \multicolumn{2}{c}{ Pooled } \\
& Coeff & $t$-stat & Coeff & $t$-stat & Coeff & $t$-stat \\
\hline Intercept & $0.068^{* *}$ & $(3.845)$ & $0.074^{* *}$ & $(3.954)$ & $0.068^{* *}$ & $(3.845)$ \\
$R E T$ & $0.054^{* *}$ & $(2.649)$ & $0.373^{*}$ & $(5.609)$ & $0.054^{* *}$ & $(2.649)$ \\
$R D$ & & & & & 0.006 & $(0.616)$ \\
$R E T^{*} R D$ & & & & & $0.319^{* *}$ & $(3.973)$ \\
Adj. $R^{2}$ & 0.06 & & 0.06 & & 0.11 & \\
$N$ & 1558 & & 1568 & & 3126 & \\
$F$-stat & 7.016 & & 31.458 & & 33.088 & \\
\hline
\end{tabular}

Model: $E_{i t} / P_{i t-l}=\beta_{0}+\beta_{1} R E T_{i t}+\beta_{2} R D_{i t}+\beta_{3} R E T_{i t} * R D_{i t}+\varepsilon_{i t}$

The sample comprises 3,126 firm-year observations from firms in Bursa Malaysia during 20032008. I use the Fama and MacBeth (1973) methodology to cope with the possible cross-sectional dependence problems. The coefficients of the parameters have been obtained as the simple average from the cross-sectional regression. The $t$-statistics are the ratios of the mean estimated Coefficients to the standard deviation of the distribution of the annual estimated slope Coefficients, divided by the square root of the number of years. Asterisks denote statistical significance at the $1 \%(*), 5 \%(* *)$, or $10 \%(* * *)$ level, respectively. Variable definitions: $E_{i t}$ is the earnings per share for firm $\mathrm{i}$ in fiscal year $\mathrm{t} ; P_{i t-1}$ is the price per share at the beginning of the fiscal year; $R E T_{i t}$ is the annual return of firm i in fiscal year $\mathrm{t} ; R D_{i t}$ is a dummy variable that equals 1 if $R E T_{i t}$ is negative, and 0 otherwise; and $\varepsilon_{i t}$ is the error term.

Table 6.7 shows the coefficients for $R E T, \beta_{1}$, in all samples are significant, showing evidence of the timeliness of earnings. The coefficient for RET in the bad news sample is 0.373 and significant at the $1 \%$ level. This is substantially higher than the good news sample, where the coefficient for RET is only $0.054(\mathrm{p}<0.05)$. The coefficient for $R E T^{*} R D$, which measures the asymmetric timeliness of earnings between the two samples, is positive (0.319) and significant at the 5\% level, implying that bad news is recognised significantly faster than good news. In essence, the results in Table 6.7 are consistent with the earlier findings that earnings conservatism is a pervasive feature of Malaysian financial reporting in the period following the institutional reforms.

\subsubsection{Industry and Year Effects}

In this section, I control for the serial correlation problems of the residuals of 
panel data by incorporating industry and year dummies in the regression model. Using the Bursa Malaysia industry classifications, I created eight industry dummies: consumer (CONS); hotel (HOTEL); infrastructure project company $(I P C)$; industrial product (IPROD); plantation (PLANT); property (PROP); technology $(T E C H)$; and trading and services $(T D G){ }^{26}$

Table 6.8

Asymmetric timeliness of earnings: Controlling for industry and year effects

\begin{tabular}{|c|c|c|c|c|c|c|}
\hline \multirow[b]{2}{*}{ Statistics } & \multicolumn{2}{|c|}{ Industry Effect } & \multicolumn{2}{|c|}{ Year Effect } & \multicolumn{2}{|c|}{ Industry \& Year Effects } \\
\hline & Coeff & $t$-stat & Coeff & $t$-stat & Coeff & $t$-stat \\
\hline Intercept & 0.027 & $(1.109)$ & $0.027 * *$ & $(2.015)$ & 0.001 & $(0.052)$ \\
\hline$R E T$ & $0.071 *$ & (4.946) & $0.068 *$ & (4.769) & $0.068 *$ & (4.703) \\
\hline$R D$ & 0.009 & $(0.601)$ & 0.003 & $(0.192)$ & 0.002 & $(0.142)$ \\
\hline$R E T^{*} R D$ & $0.191 *$ & $(4.983)$ & $0.265^{*}$ & $(6.724)$ & $0.269 *$ & $(6.747)$ \\
\hline CONS & 0.023 & $(0.879)$ & & & 0.021 & $(0.830)$ \\
\hline HOTEL & -0.034 & $(-0.632)$ & & & -0.038 & $(-0.702)$ \\
\hline$I P C$ & 0.024 & $(0.697)$ & & & 0.022 & $(0.628)$ \\
\hline IPROD & 0.039 & (1.566) & & & $0.041 * * *$ & (1.661) \\
\hline PLANT & 0.033 & (1.069) & & & 0.027 & $(0.909)$ \\
\hline PROP & 0.009 & $(0.320)$ & & & 0.011 & $(0.399)$ \\
\hline TECH & 0.034 & $(0.919)$ & & & 0.038 & (1.047) \\
\hline$T D G$ & 0.028 & (1.087) & & & 0.028 & $(1.123)$ \\
\hline$Y 2004$ & & & 0.014 & $(0.798)$ & 0.014 & $(0.805)$ \\
\hline$Y 2005$ & & & $0.067 *$ & (3.944) & $0.068^{*}$ & (3.982) \\
\hline Y2006 & & & -0.008 & $(-0.448)$ & -0.008 & $(-0.448)$ \\
\hline$Y 2007$ & & & $0.049 *$ & (3.096) & $0.049 *$ & (3.099) \\
\hline$Y 2008$ & & & $0.115^{*}$ & (6.587) & $0.116^{*}$ & (6.564) \\
\hline $\operatorname{Adj} . R^{2}$ & 0.08 & & 0.09 & & 0.09 & \\
\hline$N$ & 3126 & & 3126 & & 3126 & \\
\hline$F$-stat & 16.901 & & 27.355 & & 14.056 & \\
\hline
\end{tabular}

Model: $E_{i t} / P_{i t-1}=\beta_{0}+\beta_{1} R E T_{i t}+\beta_{2} R D_{i t}+\beta_{3} R E T_{i t} * R D_{i t}+$ Industry + Year $+\varepsilon_{i t}$

The sample comprises 3,126 firm-year observations from firms in Bursa Malaysia during 20032008. The reported $t$-statistics are in parentheses and adjusted for heteroscedasticity (White, 1980). Asterisks denote statistical significance at the $1 \%(*), 5 \%(* *)$, or $10 \%(* * *)$ level, respectively. Variable definitions: $E_{i t}$ is the earnings per share for firm i in fiscal year t; $P_{i t-1}$ is the price per share at the beginning of the fiscal year; $R E T_{i t}$ is the annual return of firm $\mathrm{i}$ in fiscal year $\mathrm{t}$; $R D_{i t}$ is a dummy variable that equals 1 if $R E T_{i t}$ is negative, and 0 otherwise; Industry are dummy variables for Bursa Malaysia industry sectors; Year are dummy variables for fiscal years; and $\varepsilon_{i t}$ is the error term.

\footnotetext{
${ }^{26}$ The Construction sector is not included in the model to avoid the perfect multi-collinearity problem.
} 
For year variables, I created five dummy variables from 2004 to 2008, while year 2003 was used as a base variable. I then re-estimated equation (5.2) with industry and year effects. Table 6.8 summarises the regression estimates including: industry effect (column 1), year effect (column 2), and both industry and year effects (column 3).

The result reported in table 6.8 shows that earnings conservatism is a strong feature of Malaysian financial reporting even after controlling for industry and year effects. The coefficient values for $R E T^{*} R D$ after controlling for industry effect, year effect, and both industry and year effects, are 0.191, 0.265, and 0.269 respectively, which are all significant at the $1 \%$ level. These results imply robust evidence of earnings conservatism in Malaysia in the period following the institutional reforms. At the same time, the results in Table 6.8 show that the coefficients for RET are positive and significant at the $1 \%$ level, suggesting that earnings are timely in the recognition of good news.

\subsubsection{Control for Firm-Specific Variables}

This section examines whether the main result is robust after controlling for firmspecific variables such as firm size $(S I Z E)$, firm leverage (LEV), and growth (MTB). Khan and Watts (2009) find these variables have significant influence on earnings conservatism. Discussion of these factors was provided in Section 5.8.3. Following LaFond and Watts (2008), I included the interaction variables of SIZE, $L E V$, and $M T B$ with $R E T, R D$ and $R E T * R D$ in equation (5.1). I then estimated the modified equation using pooled regression, Fama and MacBeth (1973) annual regression, and fixed-effects regression. The results are presented in Table 6.9. 
The regression estimates reported in Table 6.9 show qualitatively similar results to those reported in the main analysis. The coefficients for $R E T^{*} R D$ are positive and significant $(\mathrm{p}<0.01)$ in all models, implying a more timely recognition of economic losses than economic gains in Malaysia even after controlling the effect of SIZE, LEV, and MTB.

For the control variables, the results in Table 6.9 show that all the control variables have significant influence on earnings conservatism. Firm size (SIZE) has a negative relationship with earnings conservatism, where the coefficients for $S I Z E^{*} R E T^{*} R D$ are negative and significant $(\mathrm{p}<0.10)$. These results provide support for the argument that large firms have lower information asymmetry, thus reducing the contracting demands for conservatism (Khan and Watts, 2009).

For firm leverage ( $L E V$ ), the results show a positive relationship between $L E V$ and earnings conservatism. The coefficient for $L E V^{*} R E T^{*} R D$ for the pooled regression and the Fama and MacBeth (1973) annual regression are positive and significant $(\mathrm{p}<0.10)$, suggesting that high-leverage firms have higher agency costs and higher financial distress costs, hence creating greater demand for conservatism to alleviate the problems. However, the regression estimates that control for industry effect and year effects do not find any significant association between $L E V$ and conservatism. A plausible explanation is that the risks associated with a specific industry and time period have been captured by the fixed-effect variables. 
Table 6.9

Asymmetric timeliness of earnings: Controlling for firm-specific variables

\begin{tabular}{|c|c|c|c|c|c|c|}
\hline \multirow{2}{*}{$\begin{array}{c}\text { Model } \\
\text { Statistics }\end{array}$} & \multicolumn{2}{|c|}{ Pooled } & \multicolumn{2}{|c|}{ Fama-MacBeth } & \multicolumn{2}{|c|}{ Fixed Effects } \\
\hline & Coeff & $t$-stat & Coeff & $t$-stat & Coeff & $t$-stat \\
\hline Intercept & $-0.355^{*}$ & $(-3.064)$ & $-0.396^{* *}$ & $(-3.741)$ & $-0.475^{*}$ & $(-3.881)$ \\
\hline$R E T$ & -0.230 & $(-1.481)$ & -0.257 & $(-1.296)$ & -0.206 & $(-1.283)$ \\
\hline$R D$ & 0.223 & $(1.212)$ & 0.258 & (1.240) & 0.253 & (1.355) \\
\hline$R E T * R D$ & $1.071^{* * *}$ & $(2.298)$ & $1.073 * * *$ & $(2.251)$ & $1.062^{* *}$ & (2.180) \\
\hline SIZE & $0.060 *$ & $(4.251)$ & $0.064 *$ & (5.009) & $0.073^{*}$ & (4.966) \\
\hline$S I Z E * R E T$ & $0.033 * * *$ & $(1.823)$ & 0.040 & (1.610) & 0.029 & (1.573) \\
\hline$S I Z E * R D$ & -0.026 & $(-1.169)$ & -0.029 & $(-1.136)$ & -0.032 & $(-1.384)$ \\
\hline$S I Z E^{*} R E T^{*} R D$ & $-0.124 * *$ & $(-2.241)$ & $-0.117 * * *$ & $(-2.024)$ & $-0.110 * * *$ & $(-1.906)$ \\
\hline$L E V$ & $-0.294 *$ & $(-5.081)$ & $-0.213 * *$ & $(-3.856)$ & $-0.311^{*}$ & $(-5.123)$ \\
\hline$L E V^{*} R E T$ & 0.064 & $(0.869)$ & -0.035 & $(-0.300)$ & 0.066 & $(0.902)$ \\
\hline$L E V^{*} R D$ & 0.031 & $(0.313)$ & -0.009 & $(-0.165)$ & 0.035 & $(0.354)$ \\
\hline$L E V^{*} R E T * R D$ & $0.421 * * *$ & (1.803) & $0.694^{* *}$ & (3.398) & 0.360 & (1.548) \\
\hline$M T B$ & 0.002 & $(0.163)$ & -0.016 & $(-0.826)$ & -0.005 & $(-0.486)$ \\
\hline$M T B * R E T$ & -0.002 & $(-0.128)$ & 0.018 & $(0.886)$ & 0.001 & $(0.076)$ \\
\hline$M T B * R D$ & -0.003 & $(-0.166)$ & 0.005 & $(0.381)$ & 0.002 & (0.109) \\
\hline$M T B * R E T^{*} R D$ & $-0.126^{*}$ & $(-2.866)$ & $-0.238 * *$ & $(-3.383)$ & $-0.143^{*}$ & $(-3.150)$ \\
\hline CONS & & & & & 0.008 & $(0.333)$ \\
\hline HOTEL & & & & & $-0.091 * * *$ & $(-1.829)$ \\
\hline$I P C$ & & & & & -0.042 & $(-1.078)$ \\
\hline IPROD & & & & & 0.028 & $(1.210)$ \\
\hline PLANT & & & & & $-0.052 * * *$ & $(-1.732)$ \\
\hline PROP & & & & & -0.032 & $(-1.247)$ \\
\hline TECH & & & & & 0.022 & $(0.623)$ \\
\hline$T D G$ & & & & & 0.002 & $(0.102)$ \\
\hline$Y 2004$ & & & & & 0.007 & $(0.420)$ \\
\hline$Y 2005$ & & & & & $0.058^{*}$ & $(3.625)$ \\
\hline Y2006 & & & & & -0.012 & $(-0.704)$ \\
\hline$Y 2007$ & & & & & $0.034^{* *}$ & $(2.169)$ \\
\hline$Y 2008$ & & & & & $0.092 *$ & $(5.506)$ \\
\hline $\operatorname{Adj} . R^{2}$ & 0.15 & & 0.18 & & 0.16 & \\
\hline$N$ & 3126 & & 3126 & & 3126 & \\
\hline$F$-stat & 28.366 & & 19.538 & & 17.124 & \\
\hline
\end{tabular}

Model: $E_{i l} / P_{i t-1}=\beta_{0}+\beta_{1} R E T_{i t}+\beta_{2} R D_{i t}+\beta_{3} R E T_{i t} * R D_{i t}+\beta_{4} S I Z E_{i t}+\beta_{5} S I Z E_{i t} * R E T_{i t}$

$+\beta_{6} S I Z E_{i t} * R D_{i t}+\beta_{7} S I Z E_{i t} * R E T_{i t} * R D_{i t}+\beta_{8} L E V_{i t}+\beta_{9} L E V_{i t} * R E T_{i t}$

$+\beta_{10} L E V_{i t} * R D_{i t}+\beta_{11} L E V_{i t} * R E T_{i t} * R D_{i t}+\beta_{12} M T B_{i t}+\beta_{13} M T B_{i t} * R E T_{i t}$

$+\beta_{14} M T B_{i t} * R D_{i t}+\beta_{15} M T B_{i t} * R E T_{i t} * R D_{i t}+$ Industry + Year $+\varepsilon_{i t}$

The sample comprises 3,126 firm-year observations from firms in Bursa Malaysia during 20032008. The reported $t$-statistics are in parentheses and adjusted for heteroscedasticity (White, 1980). Asterisks denote statistical significance at the $1 \%(*), 5 \%(* *)$, or $10 \%(* * *)$ level, respectively. Variable definitions: $E_{i t}$ is the earnings per share for firm i in fiscal year $\mathrm{t} ; P_{i t-1}$ is the price per share at the beginning of the fiscal year; $R E T_{i t}$ is the annual return of firm $\mathrm{i}$ in fiscal year $\mathrm{t} ; R D_{i t}$ is a dummy variable that equals 1 if $R E T_{i t}$ is negative, and 0 otherwise; Industry are dummy variables for Bursa Malaysia industry sectors; Year are dummy variables for fiscal years; $S I Z E_{i t}$ is the natural logarithm of total assets for firm $\mathrm{i}$ in fiscal year $\mathrm{t} ; L E V_{i t}$ is the ratio of total debts to total 
assets for firm $\mathrm{i}$ in fiscal year $\mathrm{t}$; $M T B_{i t}$ is the market to book ratio for firm $\mathrm{i}$ in fiscal year $\mathrm{t}$; and $\varepsilon_{i t}$ is the error term.

For growth $(M T B)$, the results show a strong negative relationship between $M T B$ and earnings conservatism. The coefficients of $M T B * R E T * R D$ are negative and significant in all models, indicating that high-growth firms report more conservative earnings. This finding is consistent with the explanation given by Roychowdhury and Watts (2007) that the short horizon MTB is negatively correlated with conservatism flows due to prior unrecognised increases in asset values reducing the necessity to recognise asset value losses.

In short, the estimation results after controlling for firm-specific variables provide support for the main finding that earnings conservatism is a pervasive feature of Malaysian financial reporting following the institutional reforms. In addition, the analysis also provides evidence that SIZE, $L E V$ and $M T B$ have significant influence on earnings conservatism.

\subsubsection{Restricted Sample - Firm Audited by Big Four Auditors}

In this section, I control for the difference in audit quality of the Big Four and non-Big Four auditors. Previous studies assert that Big Four auditors (previously known as Big Five/Six/Eight) have a higher audit quality than non-Big Four auditors (DeAngelo, 1981; Francis \& Simon, 1987; Palmrose, 1988). Becker et al. (1998) and Francis et al. (1999) find that the clients of Big Six auditors report low discretionary accruals compared to the clients of non-Big Six auditors, even though clients of Big Six auditors have high levels of total accruals. These results show that Big Four auditors have a greater ability to constrain their clients' 
aggressive accounting, thus increasing the quality of earnings. Jeong and Rho (2004) state that the Big Four interpret GAAP conservatively and take a strong negotiating stance with clients who require more adjustments to the financial statements. Chung et al. (2003) find that Big Six auditors influence their clients to adopt more conservative accounting when the clients' financial performance is worse than expected.

To control for the differential quality of audit, I reduced the sample to firms audited by Big Four firms. I then re-estimated equation (5.1) using basic pooled regression, Fama and MacBeth (1973) annual regression, and fixed-effects regression controlling for industry and year effects. The results are presented in Table 6.10.

Table 6.10 shows that the regression estimates for equation (5.1) denote a qualitatively similar result as results in the main analysis. The coefficients for RET are positive and significant in all three models, suggesting that earnings are timely in recognition of good news. The coefficients for $R E T^{*} R D$, which measure earnings conservatism, are positive and significant at the $1 \%$ level. Specifically, the coefficient values for pooled regression, Fama and MacBeth (1973) annual regression, and fixed-effects regression are $0.196,0.284$, and 0.251 respectively; implying negative news is registered in earnings more promptly than positive news. All $F$-statistics are significant at the $1 \%$ level, indicating the validity of the models. 
Table 6.10

Asymmetric timeliness of earnings: Firms audited by Big Four auditors

\begin{tabular}{|c|c|c|c|c|c|c|}
\hline \multirow{2}{*}{$\begin{array}{c}\text { Model } \\
\text { Statistics }\end{array}$} & \multicolumn{2}{|c|}{ Pooled } & \multicolumn{2}{|c|}{ Fama-MacBeth } & \multicolumn{2}{|c|}{ Fixed Effects } \\
\hline & Coeff & $t$-stat & Coeff & $t$-stat & Coeff & $t$-stat \\
\hline Intercept & $0.067 *$ & (6.435) & $0.079 *$ & (5.207) & $0.073 *$ & (3.395) \\
\hline RET & $0.070^{*}$ & (4.097) & $0.053 * * *$ & (2.307) & $0.066^{*}$ & (3.859) \\
\hline$R D$ & 0.012 & $(0.845)$ & 0.007 & $(0.932)$ & 0.007 & $(0.436)$ \\
\hline$R E T * R D$ & $0.196^{*}$ & (4.949) & $0.284 *$ & (4.429) & $0.251 *$ & (6.044) \\
\hline CONS & & & & & -0.027 & $(-1.400)$ \\
\hline HOTEL & & & & & $-0.100 * * *$ & $(-1.914)$ \\
\hline$I P C$ & & & & & -0.044 & $(-1.214)$ \\
\hline IPROD & & & & & -0.011 & $(-0.598)$ \\
\hline PLANT & & & & & -0.024 & $(-0.836)$ \\
\hline PROP & & & & & -0.031 & $(-1.425)$ \\
\hline TECH & & & & & -0.005 & $(-0.118)$ \\
\hline$T D G$ & & & & & -0.029 & $(-1.491)$ \\
\hline Y2004 & & & & & 0.004 & $(0.227)$ \\
\hline Y2005 & & & & & $0.047 *$ & $(2.782)$ \\
\hline Y2006 & & & & & -0.015 & $(-0.762)$ \\
\hline Y2007 & & & & & $0.051 *$ & (3.191) \\
\hline Y2008 & & & & & $0.078 *$ & $(4.443)$ \\
\hline $\operatorname{Adj} . R^{2}$ & 0.10 & & 0.13 & & 0.11 & \\
\hline$N$ & 2063 & & 2063 & & 2063 & \\
\hline$F$-stat & 46.084 & & 54.078 & & 12.539 & \\
\hline
\end{tabular}

Model: $E_{i l} / P_{i t-1}=\beta_{0}+\beta_{1} R E T_{i t}+\beta_{2} R D_{i t}+\beta_{3} R E T_{i t} * R D_{i t}+$ Industry + Year $+\varepsilon_{i t}$

The sample comprises 3,126 firm-year observations from firms in Bursa Malaysia during 20032008. The reported $t$-statistics are in parentheses and adjusted for heteroscedasticity (White, 1980). Asterisks denote statistical significance at the $1 \%(*), 5 \%(* *)$, or $10 \%(* * *)$ level, respectively. Variable definitions: $E_{i t}$ is the earnings per share for firm i in fiscal year $\mathrm{t} ; P_{i t-l}$ is the price per share at the beginning of the fiscal year; $R E T_{i t}$ is the annual return of firm i in fiscal year $\mathrm{t} ; R D_{i t}$ is a dummy variable that equals 1 if $R E T_{i t}$ is negative, and 0 otherwise; Industry are dummy variables for Bursa Malaysia industry sectors; Year are dummy variables for fiscal years; and $\varepsilon_{i t}$ is the error term.

\subsubsection{Market-Adjusted Return}

A study by Morck et al. (2000) reported that the systematic component of returns variation is larger in emerging markets compared to the United States and other developed countries. In Malaysia, and other developing countries, the stock returns variation appears unrelated to fundamentals' co-movement, while in the United States, high firm-specific returns variation was documented. To control for 
this problem, time-series non-stationarity in the returns processes, I employed market-adjusted returns as an alternative proxy for economic news. In addition, the use of market-adjusted returns provides a useful robustness check because it can be argued that market-adjusted returns may provide a more reliable indicator for good versus bad news (Pope \& Walker, 1999).

To calculate the market-adjusted return, $R E T(M K T)$, I used the Bursa Malaysia Composite Index as a proxy for market return. I then calculated a dummy variable $R D(M K T)$, and $R E T(M K T) * R D(M K T)$ before re-estimating equation (5.1) using the basic pooled regression, Fama and MacBeth (1973) annual regression, and fixed-effects regression. The results are summarised in Table 6.11.

The results reported in Table 6.11 show qualitatively similar results to those reported in the main results, in which earnings conservatism is a strong feature of Malaysian financial reporting. The coefficients for $R E T(M K T) * R D(M K T)$ are positive and significant $(\mathrm{p}<0.01)$ in all models, implying a more timely recognition of economic losses than economic gains in Malaysia.

Specifically, the estimated value for $\left(\beta_{1}+\beta_{3}\right) / \beta_{1}$ in the pooled regression is 4.03 , implying that earnings are four times more sensitive to bad news than to good news. In other estimation models, higher estimated values for $\left(\beta_{1}+\beta_{3}\right) / \beta_{1}$ were found, showing qualitatively similar results. With respect to the validity of the models, all $F$-statistics are significant at the $1 \%$ level, while the values for adjusted- $R^{2}$ are between $8 \%$ and $10 \%$, consistent with other studies on earnings conservatism. 
Table 6.11

Asymmetric timeliness of earnings: Alternative measure for news (market adjusted return)

\begin{tabular}{|c|c|c|c|c|c|c|}
\hline \multirow{2}{*}{$\begin{array}{l}\text { Model } \\
\text { Statistics }\end{array}$} & \multicolumn{2}{|c|}{ Pooled } & \multicolumn{2}{|c|}{ Fama-MacBeth } & \multicolumn{2}{|c|}{ Fixed Effects } \\
\hline & Coeff & $t$-stat & Coeff & $t$-stat & Coeff & $t$-stat \\
\hline Intercept & $0.071 *$ & $(6.999)$ & $0.079 *$ & $(5.149)$ & 0.006 & $(0.228)$ \\
\hline$R E T(M K T)$ & $0.069 *$ & $(4.348)$ & $0.053 * * *$ & $(2.490)$ & $0.065^{*}$ & $(4.058)$ \\
\hline$R D(M K T)$ & 0.003 & $(0.216)$ & 0.010 & $(0.798)$ & 0.010 & $(0.717)$ \\
\hline$R E T(M K T) * R D(M K T)$ & $0.209^{*}$ & $(6.021)$ & $0.306^{* *}$ & $(3.727)$ & $0.271^{*}$ & (7.317) \\
\hline CONS & & & & & 0.029 & (1.118) \\
\hline HOTEL & & & & & -0.044 & $(-0.813)$ \\
\hline$I P C$ & & & & & 0.020 & $(0.548)$ \\
\hline IPROD & & & & & $0.044 * * *$ & $(1.787)$ \\
\hline PLANT & & & & & 0.025 & $(0.822)$ \\
\hline PROP & & & & & 0.008 & $(0.300)$ \\
\hline TECH & & & & & 0.043 & (1.188) \\
\hline$T D G$ & & & & & 0.031 & (1.202) \\
\hline Y2004 & & & & & $0.039 * *$ & $(2.216)$ \\
\hline Y2005 & & & & & $0.059^{*}$ & $(3.592)$ \\
\hline Y2006 & & & & & 0.007 & $(0.379)$ \\
\hline Y2007 & & & & & $0.104^{*}$ & $(6.202)$ \\
\hline$Y 2008$ & & & & & $0.042^{*}$ & $(2.707)$ \\
\hline$\beta_{1}+\beta_{3}>\beta 1$ & 4.03 & & 6.77 & & 5.17 & \\
\hline $\operatorname{Adj.} R^{2}$ & 0.08 & & 0.10 & & 0.09 & \\
\hline$N$ & 3126 & & 3126 & & 3126 & \\
\hline$F$-stat & 65.942 & & 27.964 & & 15.013 & \\
\hline
\end{tabular}

The sample comprises 3,126 firm-year observations from firms in Bursa Malaysia during 20032008. The reported $t$-statistics are in parentheses and adjusted for heteroscedasticity (White, 1980). Asterisks denote statistical significance at the $1 \%(*), 5 \%(* *)$, or $10 \%(* * *)$ level, respectively. Variable definitions: $E_{i t}$ is the earnings per share for firm i in fiscal year $\mathrm{t} ; P_{i t-l}$ is the price per share at the beginning of the fiscal year; $R E T(M K T)_{i t}$ is the market adjusted return of firm $i$ in fiscal year $\mathrm{t} ; R D(M K T)_{i t}$ is a dummy variable that equals 1 if $R E T(M K T)_{i t}$ is negative, and 0 otherwise; Industry are dummy variables for Bursa Malaysia industry sectors; Year are dummy variables for fiscal years; and $\varepsilon_{i t}$ is the error term.

\subsubsection{Inter-Announcement Period Stock Return}

In this section, I use inter-announcement period stock returns, $R E T(A N C)$, as an alternative measure for economic news. $\operatorname{RET}(A N C)$ is calculated based on the period of three months after the end of the previous fiscal year to three months 
after the current fiscal year. I re-estimated equation (5.1) using the pooled regression model, Fama and Macbeth (1973) estimation, and the estimation controlling for industry and year effects. The results are reported in Table 6.12.

Table 6.12

Asymmetric timeliness of earnings: Alternative measure for news (interannouncement date return)

\begin{tabular}{|c|c|c|c|c|c|c|}
\hline \multirow{2}{*}{$\begin{array}{c}\text { Model } \\
\text { Statistics }\end{array}$} & \multicolumn{2}{|c|}{ Pooled } & \multicolumn{2}{|c|}{ Fama-MacBeth } & \multicolumn{2}{|c|}{ Fixed Effects } \\
\hline & Coeff & $t$-stat & Coeff & $t$-stat & Coeff & $t$-stat \\
\hline Intercept & $0.067 *$ & $(6.828)$ & $0.072 *$ & $(4.112)$ & 0.001 & $(0.044)$ \\
\hline$R E T(A N C)$ & $0.050 *$ & $(2.762)$ & $0.070^{* *}$ & $(3.280)$ & $0.059^{*}$ & (3.199) \\
\hline$R D(A N C)$ & 0.015 & $(0.989)$ & 0.016 & $(1.438)$ & 0.003 & $(0.168)$ \\
\hline$R E T(A N C) * R D(A N C)$ & $0.242 *$ & $(5.512)$ & $0.325^{*}$ & (5.779) & $0.311^{*}$ & $(6.851)$ \\
\hline CONS & & & & & 0.009 & $(0.334)$ \\
\hline HOTEL & & & & & -0.042 & $(-0.749)$ \\
\hline$I P C$ & & & & & 0.004 & $(0.112)$ \\
\hline IPROD & & & & & 0.034 & $(1.335)$ \\
\hline PLANT & & & & & 0.031 & $(1.001)$ \\
\hline$P R O P$ & & & & & 0.000 & $(0.017)$ \\
\hline TECH & & & & & 0.037 & $(1.023)$ \\
\hline$T D G$ & & & & & 0.021 & $(0.811)$ \\
\hline Y2004 & & & & & $0.066^{*}$ & $(3.556)$ \\
\hline$Y 2005$ & & & & & $0.074 *$ & (4.194) \\
\hline$Y 2006$ & & & & & -0.004 & $(-0.232)$ \\
\hline$Y 2007$ & & & & & $0.093^{*}$ & $(5.397)$ \\
\hline$Y 2008$ & & & & & $0.142 *$ & $(7.730)$ \\
\hline $\operatorname{Adj} . R^{2}$ & 0.04 & & 0.07 & & 0.07 & \\
\hline$N$ & 3124 & & 3124 & & 3124 & \\
\hline$F$-stat & 37.886 & & 106.921 & & 12.186 & \\
\hline
\end{tabular}

The sample comprises 3,126 firm-year observations from firms in Bursa Malaysia during 20032008. The reported $t$-statistics are in parentheses and adjusted for heteroscedasticity (White, 1980). Asterisks denote statistical significance at the $1 \%(*), 5 \%(* *)$, or $10 \%(* * *)$ level, respectively. Variable definitions: $E_{i t}$ is the earnings per share for firm i in fiscal year $\mathrm{t} ; P_{i t-1}$ is the price per share at the beginning of the fiscal year; $R E T(A N C)_{i t}$ is the announcement date return of firm $\mathrm{i}$ in fiscal year $\mathrm{t}$; $R D(A N C)_{i t}$ is a dummy variable that equals 1 if $R E T(A N C)_{i t}$ is negative, and 0 otherwise; Industry are dummy variables for Bursa Malaysia industry sectors; Year are dummy variables for fiscal years; and $\varepsilon_{i t}$ is the error term.

With regard to earnings conservatism, the results reported in Table 6.12 show that the coefficients for $R E T(A N C) * R D(A N C)$ are positive and significant at the $1 \%$ 
level in all models, implying that bad news is recognised in a more timely fashion than is good news. In short, the results support the prediction managers and preparers of financial reports have higher incentives to report earnings conservatively in order to meet higher market demand for quality accounting information following the institutional reforms.

\subsubsection{Reduced Sample: Stock Price Higher than MYR 1.00}

In this section, I reduce my set of firm-year observations to include only firms with stock prices higher than MYR 1.00. This procedure was undertaken to avoid the creation of artificial scale problems that could lead to the nonlinearity of the model (Kothari \& Zimmerman, 1995). In addition, smaller firms have, on average, less liquid stocks, greater information asymmetry and higher idiosyncratic uncertainty (Khan \& Watts, 2009). For this reason many studies do not include those observations where the deflator (price at the beginning of the period) is smaller than one dollar. For example, García Lara and Mora (2004) exclude observations with stock prices less than one Euro, while Lobo and Zhou (2006) and Khan and Watts (2009) exclude observations with stock prices below US\$ 1.00 .

As a result of excluding all observation with stock price less than MYR 1.00., the number of sample reduces to 1,312 firm-year observations. I then re-estimated equation (5.1) using basic pooled regression, Fama and MacBeth (1973) annual regression, and fixed-effects regression controlling for industry and year effects. The regression estimates are summarised in Table 6.13. 
Table 6.13

Asymmetric timeliness of earnings: Sample with stock price greater than MYR 1.00

\begin{tabular}{|c|c|c|c|c|c|c|}
\hline \multirow{2}{*}{$\begin{array}{l}\text { Sample } \\
\text { Statistics }\end{array}$} & \multicolumn{2}{|c|}{ Pooled } & \multicolumn{2}{|c|}{ Fama-MacBeth } & \multicolumn{2}{|c|}{ Fixed Effects } \\
\hline & Coeff & $t$-stat & Coeff & $t$-stat & Coeff & $t$-stat \\
\hline Intercept & $0.075^{*}$ & $(8.834)$ & $0.083^{*}$ & $(8.999)$ & 0.019 & $(0.730)$ \\
\hline RET & $0.070^{*}$ & (5.714) & $0.057 *$ & (4.713) & $0.067 *$ & (5.567) \\
\hline$R D$ & 0.016 & (1.073) & $0.027 * * *$ & (2.036) & 0.011 & $(0.746)$ \\
\hline$R E T * R D$ & $0.185^{*}$ & (2.969) & $0.361 * *$ & (3.536) & $0.249 *$ & (3.778) \\
\hline CONS & & & & & 0.028 & (1.114) \\
\hline HOTEL & & & & & 0.026 & $(0.925)$ \\
\hline$I P C$ & & & & & 0.041 & (1.345) \\
\hline IPROD & & & & & 0.028 & (1.094) \\
\hline PLANT & & & & & 0.000 & $(0.003)$ \\
\hline PROP & & & & & 0.030 & (1.080) \\
\hline TECH & & & & & 0.042 & (1.515) \\
\hline$T D G$ & & & & & 0.010 & $(0.362)$ \\
\hline Y2004 & & & & & 0.013 & $(0.664)$ \\
\hline Y2005 & & & & & $0.052 * *$ & (2.506) \\
\hline Y2006 & & & & & 0.011 & $(0.470)$ \\
\hline Y2007 & & & & & $0.080^{*}$ & (4.714) \\
\hline Y2008 & & & & & $0.115^{*}$ & (5.098) \\
\hline $\operatorname{Adj} . R^{2}$ & 0.10 & & 0.14 & & 0.14 & \\
\hline$N$ & 1312 & & 1312 & & 1312 & \\
\hline$F$-stat & 24.331 & & 70.483 & & 7.715 & \\
\hline
\end{tabular}

Model: $E_{i t} / P_{i t-1}=\beta_{0}+\beta_{1} R E T_{i t}+\beta_{2} R D_{i t}+\beta_{3} R E T_{i t} * R D_{i t}+$ Industry + Year $+\varepsilon_{i t}$

The sample comprises 1,312 firm-year observations from firms in Bursa Malaysia during 20032008. The reported $t$-statistics are in parentheses and adjusted for heteroscedasticity (White, 1980). Asterisks denote statistical significance at the $1 \%(*), 5 \%(* *)$, or $10 \%(* * *)$ level, respectively. Variable definitions: $E_{i t}$ is the earnings per share for firm i in fiscal year $\mathrm{t} ; P_{i t-l}$ is the price per share at the beginning of the fiscal year; $R E T_{i t}$ is the annual return of firm i in fiscal year $\mathrm{t} ; R D_{i t}$ is a dummy variable that equals 1 if $R E T_{i t}$ is negative, and 0 otherwise; Industry are dummy variables for Bursa Malaysia industry sectors; Year are dummy variables for fiscal years; and $\varepsilon_{i t}$ is the error term.

Consistent with the earlier results, I find robust evidence for earnings conservatism in Malaysia. The coefficients for $R E T^{*} R D$, which measure earnings conservatism, are positive and significant at the $1 \%$ level, hence providing evidence of earnings conservatism in Malaysia following the institutional reforms. Specifically, the coefficient values for pooled regression, Fama and MacBeth (1973) annual regression, and fixed-effects regression are $0.185,0.361$, and 0.249 
respectively. These results imply that earnings reflect bad news in a more timely manner than they reflect good news. All $F$-statistics are significant at the $1 \%$ level, while adjusted- $R^{2}$ s are between $10 \%$ and $14 \%$, indicating the validity of the models.

\subsubsection{Time-series Test of Timeliness in Loss Recognition}

Several studies, for example Dietrich et al. (2007), criticise the application of Basu (1997) reverse regression as a measure for earnings conservatism. The detailed criticisms have been provided in Section 5.8.4. To overcome these criticisms, I followed the suggestion made by Ryan (2006) on the use of multiple measures for earnings conservatism. Similar to Basu (1997) and Ball et al. (2000), I use the time-series test of timeliness in loss recognition as an alternative measure for earnings conservatism.

In the time-series test of timeliness in loss recognition model, I examine the persistence of changes in earnings, a function of the sign of the past-period change, as an alternative measure for earnings conservatism. Economic income is assumed to be completely transitory or independent across time. When earnings reflect economic gains and losses in a timely manner, it will incorporate transitory components. To the extent that earnings smoothes economic income over time, primarily by awaiting the realization of changes in cash flows, it will exhibit persistence. If earnings are asymmetrically conservative in the Basu (1997) sense, primarily by anticipating decreases but not increases in expected future cash flows, it will exhibit larger transitory decreases than increases. 
To examine the persistence of changes in earnings, I re-estimated equation (1.2) using basic pooled regression, a Fama and MacBeth (1973) annual regression, and fixed-effects regression. The results are reported in Table 6.14. Consistent with the results reported in Basu's reverse regression, the regression estimates show evidence of earnings conservatism in Malaysia following the institutional reforms. The results from the time-series test of timeliness in loss recognition show that earnings decreases are much less persistent (more transitory) than earnings increases. The coefficient for $\Delta N I_{i t-1} * D \Delta N I_{i t-1}, \alpha_{3}$, is $-0.701(\mathrm{p}<0.01)$ which is incremental with respect to the $\alpha_{1}$ with coefficient of $-0.116(\mathrm{p}<0.05)$. This result implies accounting income reflects economic losses more quickly than economic profits in the period after the corporate governance and financial reporting reforms in Malaysia.

The regression estimates from the Fama and MacBeth (1973) annual regression and estimation controlling for industry and year effects shows similar results. For the Fama and MacBeth (1973) annual regression, the coefficient for $\Delta N I_{i t-1}, \alpha_{1}$, $0.104(p>0.10)$, shows no evidence of reversal of prior earnings increase, while the coefficient for $\Delta N I_{i t-1}{ }^{*} D \wedge N I_{i t-1}$ is $-0.741 \quad(\mathrm{p}<0.01)$, indicating significant evidence that earnings decreases are more transitory than earnings increases. The evidence from the estimation results after controlling for industry effects and year effects also reaches a similar conclusion: the coefficient for $\triangle N I_{i t-1} * D \triangle N I_{i t-1}$ is $0.704(p<0.01)$, suggesting that Malaysian firms report earnings conservatively. 
Table 6.14

Time-series test of timeliness in loss recognition: Various specifications

\begin{tabular}{|c|c|c|c|c|c|c|}
\hline \multirow{2}{*}{$\begin{array}{c}\text { Sample } \\
\text { Statistics }\end{array}$} & \multicolumn{2}{|c|}{ Pooled } & \multicolumn{2}{|c|}{ Fama-MacBeth } & \multicolumn{2}{|c|}{ Fixed Effects } \\
\hline & Coeff & $t$-stat & Coeff & $t$-stat & Coeff & $t$-stat \\
\hline Intercept & $0.006^{*}$ & $(-2.674)$ & 0.006 & $(-1.983)$ & 0.003 & $(-0.417)$ \\
\hline$\Delta N I_{t-1}$ & $-0.116^{* *}$ & $(-2.184)$ & -0.104 & $(-1.312)$ & $-0.115^{*}$ & $(-5.710)$ \\
\hline$D \triangle N I_{t-1}$ & $-0.017^{*}$ & $(-4.259)$ & $-0.018 * *$ & $(-2.981)$ & $-0.017^{*}$ & $(-4.596)$ \\
\hline$\Delta N I_{t-1} * D \wedge N I_{t-1}$ & $-0.701 *$ & $(-6.707)$ & $-0.741^{*}$ & $(-6.185)$ & $-0.704 *$ & $(-15.555)$ \\
\hline CONS & & & & & -0.002 & $(-0.282)$ \\
\hline HOTEL & & & & & 0.001 & $(-0.048)$ \\
\hline$I P C$ & & & & & -0.005 & $(-0.344)$ \\
\hline IPROD & & & & & 0.001 & $(-0.080)$ \\
\hline PLANT & & & & & $0.014 * * *$ & $(-1.671)$ \\
\hline PROP & & & & & -0.002 & $(-0.342)$ \\
\hline TECH & & & & & -0.006 & $(-0.625)$ \\
\hline$T D G$ & & & & & 0.000 & $(-0.065)$ \\
\hline Y2004 & & & & & 0.002 & $(-0.357)$ \\
\hline Y2005 & & & & & 0.000 & $(-0.081)$ \\
\hline Y2006 & & & & & 0.002 & $(-0.441)$ \\
\hline Y2007 & & & & & $0.016^{*}$ & $(-3.154)$ \\
\hline Y2008 & & & & & -0.001 & $(-0.264)$ \\
\hline $\operatorname{Adj} . R^{2}$ & 0.14 & & 0.16 & & 0.15 & \\
\hline$N$ & 3105 & & 3105 & & 3105 & \\
\hline$F$-stat & 33.33 & & 47.732 & & 33.131 & \\
\hline
\end{tabular}

The sample comprises 3,105 firm-year observations from firms in Bursa Malaysia during 20032008. The reported $t$-statistics are in parentheses and adjusted for heteroscedasticity (White, 1980). Asterisks denote statistical significance at the $1 \%(*), 5 \%(* *)$, or $10 \%(* * *)$ level, respectively. Variable definitions: $\triangle N I_{i t}$ is the change in earnings for firm i from year t- 1 to year $t$, standardised by total assets at end of year t-1;D $D N I_{i t-1}$ is a dummy variable that equals 1 if $\Delta N I_{i t-l}$ if negative, and 0 otherwise; Industry are dummy variables for Bursa Malaysia industry sectors; Year are dummy variables for fiscal years; and $\varepsilon_{i t}$ is the error term.

In short, the results from the time-series test of timeliness in the loss recognition model are consistent with those reported in the main results. Earnings reported in Malaysia, following the institutional reforms, is timely in recognising losses compared to gains, and thus provides evidence to reject the first null hypothesis. 


\subsubsection{Discussion of the Results}

In the first hypothesis, I predict that earnings conservatism is pervasive in Malaysia following the institutional reforms because of the high demand and incentives to produce high-quality reporting of earnings. Previously, Ball et al. (2003) found no evidence of earnings conservatism in a sample from 1984 to 1996, and concluded that Malaysian financial reporting is of low quality. In this study, I argue that institutional reforms have provided strong demand and incentives for high-quality reporting.

The results show that there is robust evidence of earnings conservatism following the institutional reforms, in which economic losses are recognised in a more timely way than are economic gains. Specifically, earnings are at least three times more sensitive to negative stock returns than to positive stock returns. These results are also robust to various sensitivity tests, including: (1) estimation of Fama-Macbeth t-statistics; (2) estimation controlling for industry and year effects; (3) estimation controlling for firm size, leverage and market to book ratio; (4) controlling for differential audit quality; (5) controlling the effect of market return; (6) employing inter-announcement stock returns as proxy for economic news; (7) reducing the observation to firms with a share price greater than MYR 1.00; and (8) estimation of the time-series test of timeliness in loss recognition model. All the results support the prediction concerning earnings conservatism (that bad news is recognised in a more timely way than is good news); hence the results provide enough evidence to reject the first null hypothesis.

This finding provides support to the arguments made by Bushman and Piotroski 
(2006) and Ball et al. (2003) that country-specific factors and preparers' incentives have significant influence in earnings conservatism. Evidence of earnings conservatism in the post-reform period shows that firms have greater incentives and demands to report high quality earnings, in particular by more timely recognition of bad news compared to good news. Contrary to the period before the economic crisis where the weak institutional structures resulted in less incentive to preparers to report earnings conservatively (Ball, et al., 2003).

\subsection{IFRS Adoption and Earnings Conservatism}

\subsubsection{Introduction}

The second objective of this study concentrates on the effect of IFRS adoption on earnings conservatism. The main empirical results are reported in Section 6.4.2, which includes comparison of earnings conservatism levels before and after adoption of IFRS, based on one-year and two-year horizons. Section 6.4.3 presents various sensitivity tests, including control for industry and year effects; restricting the sample to observations with a financial year end dated 31 December; limiting the analysis to firms with Big Four auditors; and restricting the observations to firms audited by an industry specialist. In addition, the sensitivity tests also include the time-series test in loss recognition. Section 6.4.4 summarises the findings.

\subsubsection{Main Analysis: The Effect of IFRS Adoption on Earnings Conservatism}

To examine the effect of IFRS adoption on earnings conservatism, I estimated the 
Basu (1997) reverse earnings-return regression, equation (5.1), for two subsamples: (i) one year before and after IFRS adoption, and (ii) two years before and after IFRS adoption. Panel A Table 6.15 reports the regression estimates for the sample for the one-year period before and after IFRS, while Panel B reports the results based on the sample for two years before and after IFRS adoption.

The result in Column 1 Panel A presents regression estimates for equation (5.1) for a sample of 521 firms before the adoption of IFRS (the MASB accounting standards), while Column 2 Panel A reports the regression estimates for the first year after the adoption (the IFRS accounting standards). The coefficients for $R E T^{*} R D$ are positive and significant in both columns, showing evidence of earnings conservatism in both periods.

I further regressed equation (5.2) to test for significant difference between the level of earnings conservatism during the MASB and IFRS financial reporting regimes. The results are summarised in Column 3. In equation (5.2), the coefficient for $I F R S^{*} R E T * R D$ measures the incremental earnings conservatism for the post-IFRS period. If the coefficient for IFRS*RET*RD is negative (positive) and significant, the post-IFRS period has lower (higher) earnings conservatism than pre-IFRS period. The results summarised in Column 3 Panel A show that the coefficient for IFRS*RET*RD is not significant $(\mathrm{p}>0.10)$, suggesting no evidence for any significant difference in the level of earnings conservatism between the two financial regimes.

Given that the effect of IFRS on earnings conservatism may not be clearly 
observed in the first year after IFRS adoption, I extended the horizon to two years before and after IFRS adoption. The regression estimates are reported in Panel B.

Table 6.15

IFRS adoption and earnings conservatism

Panel A: One year before and after IFRS adoption

\begin{tabular}{lcccccc}
\hline \multicolumn{1}{c}{ Sample } & \multicolumn{2}{c}{ Pre-IFRS } & \multicolumn{2}{c}{ Post-IFRS } & \multicolumn{2}{c}{ Pooled } \\
\cline { 2 - 7 } \multicolumn{1}{c}{ Statistics } & Coeff & $t$-stat & Coeff & $t$-stat & Coeff & $t$-stat \\
\hline Intercept & $0.083^{* * *}$ & $(1.704)$ & $0.053^{* *}$ & $(2.390)$ & $0.083^{* * *}$ & $(1.704)$ \\
$R E T$ & -0.066 & $(-0.419)$ & 0.056 & $(1.496)$ & -0.066 & $(-0.419)$ \\
$R D$ & -0.014 & $(-0.251)$ & -0.007 & $(-0.178)$ & -0.014 & $(-0.251)$ \\
$R E T^{*} R D$ & $0.410^{* *}$ & $(2.254)$ & $0.505^{* *}$ & $(2.251)$ & $0.410^{* *}$ & $(2.254)$ \\
$I F R S$ & & & & & -0.030 & $(-0.566)$ \\
$I F R S^{*} R E T$ & & & & & 0.122 & $(0.751)$ \\
$I F R S^{*} R D$ & & & & & 0.007 & $(0.099)$ \\
$I F R S^{*} R E T^{*} R D$ & & & & & 0.095 & $(0.328)$ \\
Adj. $R^{2}$ & 0.05 & & 0.07 & & 0.06 & \\
$N$ & 521 & & 521 & & 1042 & \\
$F$-stat & 8.399 & & 7.787 & & 8.063 & \\
\hline
\end{tabular}

Panel B: Two years before and after IFRS adoption

\begin{tabular}{lllllll}
\hline \multicolumn{1}{c}{ Sample } & \multicolumn{2}{c}{ Pre-IFRS } & \multicolumn{2}{c}{ Post-IFRS } & \multicolumn{2}{c}{ Pooled } \\
\cline { 2 - 7 } \multicolumn{1}{c}{ Statistics } & Coeff & $t$-stat & Coeff & $t$-stat & Coeff & $t$-stat \\
\hline Intercept & $0.068^{*}$ & $(3.769)$ & $0.065^{*}$ & $(4.637)$ & $0.068^{*}$ & $(3.769)$ \\
$R E T$ & $0.061^{* * *}$ & $(1.749)$ & $0.076^{*}$ & $(3.574)$ & $0.061^{* * *}$ & $(1.749)$ \\
$R D$ & 0.003 & $(0.100)$ & 0.006 & $(0.249)$ & 0.003 & $(0.100)$ \\
$R E T^{*} R D$ & $0.274^{*}$ & $(3.941)$ & $0.207^{*}$ & $(2.909)$ & $0.274^{*}$ & $(3.941)$ \\
$I F R S$ & & & & & -0.004 & $(-0.161)$ \\
$I F R S^{*} R E T$ & & & & & 0.015 & $(0.369)$ \\
$I F R S^{*} R D$ & & & & & 0.003 & $(0.095)$ \\
$I F R S^{*} R E T^{*} R D$ & & & & & -0.067 & $(-0.674)$ \\
Adj. $R^{2}$ & 0.08 & & 0.09 & & 0.09 & \\
$N$ & 1042 & & 1042 & & 2084 & \\
$F$-stat & 25.151 & & 20.807 & & 21.813 & \\
\hline
\end{tabular}

Model: $E_{i t} / P_{i t-1}=\beta_{0}+\beta_{1} R E T_{i t}+\beta_{2} R D_{i t}+\beta_{3} R E T_{i t} * R D_{i t}+\beta_{4} I F R S_{i t}+\beta_{5} I F R S_{i t} * R E T_{i t}$ $+\beta_{6} I_{F R S_{i t}} * R D_{i t}+\beta_{7} I F R S_{i t} * R E T_{i t} * R D_{i t}+\varepsilon_{i t}$

The reported $t$-statistics are in parentheses and adjusted for heteroscedasticity (White, 1980). Asterisks denote statistical significance at the $1 \%(*), 5 \%(* *)$, or $10 \%(* * *)$ level, respectively. Variable definitions: $E_{i t}$ is the earnings per share for firm i in fiscal year t; $P_{i t-1}$ is the price per share at the beginning of the fiscal year; $R E T_{i t}$ is the annual return of firm i in fiscal year $\mathrm{t}$; $R D_{i t}$ is a dummy variable that equals 1 if $R E T_{i t}$ is negative, and 0 otherwise; IFRS is a dummy variable that takes value 1 if the financial statements are prepared according to IFRS standards, and 0 otherwise; and $\varepsilon_{i t}$ is the error term. 
The results presented in column 1 and column 2 show that earnings conservatism is pervasive in both periods. In the pre-IFRS adoption period, column 1, the coefficient for $R E T^{*} R D$ is positive $(0.274)$ and statistically significant $(\mathrm{p}<0.01)$, while in the period after the adoption of IFRS, column 2, the coefficient for $R E T^{*} R D$ is positive $(0.207)$ and significant $(\mathrm{p}<0.01)$, showing evidence of earnings conservatism in both financial reporting regimes. In column 3 , the result shows that the coefficient for $I F R S^{*} R E T^{*} R D$ is -0.067 which suggests that the post-IFRS period has lower earnings conservatism than the pre-IFRS period. However, this coefficient is not significant $(\mathrm{p}>0.10)$ and therefore there is no significant difference in earnings conservatism between the two periods.

Overall, the results presented in Table 6.15 suggest that there is no significant difference in the levels of earnings conservatism between the pre- and post-IFRS adoption period; hence the results fail to provide enough evidence to reject the second hypothesis. This implies that though the new standards (IFRS) are linked to more relevant and less prudent (conservative) financial reports, managers and auditors strongly perceived that earnings conservatism is a financial reporting attribute that should be preserved.

\subsubsection{Sensitivity Tests}

To test the strength of the main results, several robustness tests were carried out. First, I controlled for industry and year effects. Second, I limited my observations to firms with financial year end dated 31 December. Third, I restricted the sample to firms audited by Big Four auditors. Fourth, I concentrated on firms audited by an industry specialist. Finally, I employed the time-series test in the loss 
recognition model as an alternative measure for earnings conservatism.

\subsubsection{Control for Industry and Year Effects}

This section presents the regression estimates for equation (5.2) incorporating the control for industry and year effects. The regression estimates on both samples, one year and two years before and after IFRS adoption, are presented in Table 6.16.

Similarly to the earlier results, the results reported in Table 6.16 show no significant changes in earnings conservatism between pre- and post-IFRS adoption periods even after controlling for industry and year effects. Neither of the regression models has statistically significant coefficients for IFRS*RET*RD for both samples, of one year and two years before and after IFRS. I could thus conclude that there is no difference in the degrees of earnings conservatism as a result of IFRS adoption.

Overall, the results imply that managers and preparers of financial reports have a higher tendency to ensure timely recognition of unfavourable economic news than to ensure timely recognition of favourable economic news, though the IFRS standards demands relevance and neutral (unbiased) information. In terms of the validity of the results, all $F$-statistics are significant at the $1 \%$ level, while the adjusted- $R^{2}$ for the model is between $10 \%$ and $11 \%$. 
Table 6.16

IFRS adoption and earnings conservatism: Controlling the effect of industry and year effects

\begin{tabular}{|c|c|c|c|c|}
\hline \multirow{2}{*}{$\begin{array}{c}\text { Sample } \\
\text { Statistics }\end{array}$} & \multicolumn{2}{|c|}{ One Year } & \multicolumn{2}{|c|}{ Two Years } \\
\hline & Coeff & $t$-stat & Coeff & $t$-stat \\
\hline Intercept & 0.086 & $(1.011)$ & -0.016 & $(-0.277)$ \\
\hline RET & -0.108 & $(-0.641)$ & 0.030 & $(0.502)$ \\
\hline$R D$ & -0.033 & $(-0.524)$ & 0.002 & $(0.050)$ \\
\hline$R E T^{*} R D$ & $0.543 *$ & $(2.729)$ & $0.354 *$ & $(3.645)$ \\
\hline IFRS & -0.061 & $(-1.023)$ & 0.039 & $(1.011)$ \\
\hline$I F R S * R E T$ & 0.073 & $(0.411)$ & 0.042 & $(0.639)$ \\
\hline$I F R S^{*} R D$ & 0.052 & $(0.584)$ & 0.002 & $(0.031)$ \\
\hline$I F R S * R E T * R D$ & 0.643 & $(1.502)$ & 0.159 & $(0.809)$ \\
\hline CONS & 0.038 & $(0.500)$ & 0.074 & $(1.372)$ \\
\hline HOTEL & 0.071 & (0.959) & 0.084 & (1.594) \\
\hline$I P C$ & 0.075 & $(0.747)$ & 0.048 & $(0.689)$ \\
\hline IPROD & 0.105 & (1.485) & $0.115^{* *}$ & $(2.214)$ \\
\hline PLANT & 0.043 & $(0.602)$ & $0.096 * * *$ & (1.713) \\
\hline PROP & -0.019 & $(-0.231)$ & 0.006 & $(0.108)$ \\
\hline TECH & 0.076 & $(0.766)$ & 0.118 & (1.599) \\
\hline$T D G$ & 0.105 & $(1.482)$ & $0.119^{* *}$ & $(2.325)$ \\
\hline Y2005 & & & 0.029 & (1.192) \\
\hline Y2006 & & & $-0.082 *$ & $(-3.210)$ \\
\hline $\operatorname{Adj} . R^{2}$ & 0.10 & & 0.11 & \\
\hline$N$ & 588 & & 1176 & \\
\hline$F$-stat & 4.464 & & 7.994 & \\
\hline
\end{tabular}

Asterisks denote statistical significance at the $1 \%(*), 5 \%(* *)$, or $10 \%(* * *)$ level, respectively. Variable definitions: $E_{i t}$ is the earnings per share for firm i in fiscal year $\mathrm{t} ; P_{i t-1}$ is the price per share at the beginning of the fiscal year; $R E T_{i t}$ is the annual return of firm $\mathrm{i}$ in fiscal year $\mathrm{t} ; R D_{i t}$ is a dummy variable that equals 1 if $R E T_{i t}$ is negative, and 0 otherwise; IFRS is a dummy variable that takes value 1 if the financial statements are prepared according to IFRS standards, and 0 otherwise; Industry are dummy variables for Bursa Malaysia industry sectors; Year are dummy variables for fiscal years; and $\varepsilon_{i t}$ is the error term.

\subsubsection{Sample of Firms with Financial Year Ended 31 December}

For the testing reported in this section, the observations are restricted to firms with a financial year ended 31 December. This procedure was undertaken to control for time effects that might influence the measurement for economic news. I reestimated equation (5.1) on the sample of one year and two years before and after 
IFRS adoption. For the pooled sample, I re-estimated equation (5.2) to test for significant difference in earnings conservatism between the pre and post-IFRS periods. The results are presented in Table 6.17, which includes the results for: (i) pre-IFRS period (Column 1); post-IFRS period (Column 2); and pooled sample (Column 3).

Table 6.17

IFRS Adoption and earnings conservatism: Sample with financial year end dated 31 December

Panel A: One year before and after IFRS adoption

\begin{tabular}{|c|c|c|c|c|c|c|}
\hline \multirow{2}{*}{$\begin{array}{c}\text { Sample } \\
\text { Statistics }\end{array}$} & \multicolumn{2}{|c|}{ Pre-IFRS } & \multicolumn{2}{|c|}{ Post-IFRS } & \multicolumn{2}{|c|}{ Pooled } \\
\hline & Coeff & $t$-stat & Coeff & $t$-stat & Coeff & $t$-stat \\
\hline Intercept & $0.162 *$ & $(3.195)$ & $0.093 *$ & $(3.070)$ & $0.162 *$ & (3.195) \\
\hline$R E T$ & -0.112 & $(-0.664)$ & -0.031 & $(-0.518)$ & -0.112 & $(-0.664)$ \\
\hline$R D$ & -0.047 & $(-0.752)$ & 0.019 & $(0.284)$ & -0.047 & $(-0.752)$ \\
\hline$R E T^{*} R D$ & $0.528 *$ & $(2.642)$ & $1.151 *$ & (2.957) & $0.528 *$ & (2.642) \\
\hline IFRS & & & & & -0.070 & $(-1.184)$ \\
\hline$I F R S^{*} R E T$ & & & & & 0.081 & $(0.450)$ \\
\hline$I F R S^{*} R D$ & & & & & 0.066 & $(0.727)$ \\
\hline$I F R S^{*} R E T * R D$ & & & & & 0.624 & (1.426) \\
\hline$A d j . R^{2}$ & 0.10 & & 0.08 & & 0.09 & \\
\hline$N$ & 294 & & 294 & & 588 & \\
\hline$F$-stat & 13.272 & & 5.145 & & 7.985 & \\
\hline
\end{tabular}

Panel B: Two years before and after IFRS adoption

\begin{tabular}{|c|c|c|c|c|c|c|}
\hline \multirow{2}{*}{$\begin{array}{c}\text { Sample } \\
\text { Statistics }\end{array}$} & \multicolumn{2}{|c|}{ Pre-IFRS } & \multicolumn{2}{|c|}{ Post-IFRS } & \multicolumn{2}{|c|}{ Pooled } \\
\hline & Coeff & $t$-stat & Coeff & $t$-stat & Coeff & $t$-stat \\
\hline Intercept & $0.089 *$ & $(3.682)$ & $0.067^{*}$ & (3.739) & $0.089 *$ & (3.682) \\
\hline$R E T$ & 0.031 & $(0.533)$ & $0.072 * *$ & $(2.452)$ & 0.031 & $(0.533)$ \\
\hline$R D$ & -0.008 & $(-0.212)$ & 0.002 & $(0.054)$ & -0.008 & $(-0.212)$ \\
\hline$R E T^{*} R D$ & $0.326 *$ & $(3.301)$ & $0.428 * *$ & $(2.401)$ & $0.326^{*}$ & (3.301) \\
\hline IFRS & & & & & -0.022 & $(-0.722)$ \\
\hline$I F R S^{*} R E T$ & & & & & 0.041 & $(0.637)$ \\
\hline$I F R S * R D$ & & & & & 0.010 & $(0.188)$ \\
\hline$I F R S * R E T * R D$ & & & & & 0.102 & $(0.501)$ \\
\hline $\operatorname{Adj} . R^{2}$ & 0.08 & & 0.09 & & 0.09 & \\
\hline$N$ & 588 & & 588 & & 1176 & \\
\hline$F$-stat & 20.066 & & 10.380 & & 14.104 & \\
\hline
\end{tabular}

Model: $E_{i l} / P_{i t-1}=\beta_{0}+\beta_{1} R E T_{i t}+\beta_{2} R D_{i t}+\beta_{3} R E T_{i t} * R D_{i t}+\beta_{4} I F R S_{i t}+\beta_{5} I F R S_{i t} * R E T_{i t}$

$$
+\beta_{6} \text { IFRS }_{i t} * R D_{i t}+\beta_{7} I F R S_{i t} * R E T_{i t} * R D_{i t}+\varepsilon_{i t}
$$

The reported $t$-statistics are in parentheses and adjusted for heteroscedasticity (White, 1980). Asterisks denote statistical significance at the $1 \%(*), 5 \%(* *)$, or $10 \%(* * *)$ level, respectively. 
Variable definitions: $E_{i t}$ is the earnings per share for firm i in fiscal year t; $P_{i t-1}$ is the price per share at the beginning of the fiscal year; $R E T_{i t}$ is the annual return of firm $\mathrm{i}$ in fiscal year $\mathrm{t}$; $R D_{i t}$ is a dummy variable that equals 1 if $R E T_{i t}$ is negative, and 0 otherwise; IFRS is a dummy variable that takes value 1 if the financial statements are prepared according to IFRS standards, and 0 otherwise; and $\varepsilon_{i t}$ is the error term.

The results reported in Panel A and Panel B show that the coefficients for $R E T^{*} R D$ are positive and significant at the $1 \%$ level, indicating evidence of earnings conservatism in Malaysia in both periods. However, the coefficients for $I F R S^{*} R E T * R D$ in both samples, one year and two years, are positive but insignificant ( $>0.10)$, suggesting that there is no significant difference in earnings conservatism between the MASB and IFRS reporting periods.

Overall, the findings reported in Table 6.17 are qualitatively similar to the main results. The analyses find no evidence of significant difference in the levels of earnings conservatism between the MASB and IFRS reporting periods, and thus fail to provide evidence to reject the second hypothesis.

\subsubsection{Firms with Big Four Auditors}

Given the evidence from prior studies that Big Four auditors have higher audit quality, it is important to control for differential audit quality. Detailed discussion was provided in Section 6.3.3.4.

To control for audit quality, I re-estimated equation (5.2) on a restricted sample of firms with Big Four auditors. The regression estimates for equation (5.2) are reported in Table 6.18, including samples of one year and two years before and after IFRS adoption. 
Table 6.18

IFRS Adoption and earnings conservatism: Sample of firms with Big 4 auditors

\begin{tabular}{|c|c|c|c|c|}
\hline \multirow{2}{*}{$\begin{array}{l}\text { Sample } \\
\text { Statistics }\end{array}$} & \multicolumn{2}{|c|}{ One Year } & \multicolumn{2}{|c|}{ Two Years } \\
\hline & Coeff & $t$-stat & Coeff & $t$-stat \\
\hline Intercept & $0.096 * * *$ & $(1.825)$ & $0.074 *$ & $(3.541)$ \\
\hline RET & -0.135 & $(-0.941)$ & 0.056 & (1.498) \\
\hline$R D$ & 0.021 & $(0.367)$ & 0.023 & $(0.840)$ \\
\hline$R E T * R D$ & $0.523 *$ & (3.196) & $0.303^{*}$ & (4.309) \\
\hline IFRS & -0.033 & $(-0.563)$ & 0.012 & $(0.439)$ \\
\hline$I F R S * R E T$ & 0.194 & (1.289) & 0.011 & $(0.226)$ \\
\hline$I F R S^{*} R D$ & -0.001 & $(-0.016)$ & -0.039 & $(-1.051)$ \\
\hline$I F R S^{*} R E T^{*} R D$ & -0.048 & $(-0.171)$ & -0.128 & $(-1.260)$ \\
\hline $\operatorname{Adj.} R^{2}$ & 0.08 & & 0.10 & \\
\hline$N$ & 694 & & 1381 & \\
\hline$F$-stat & 6.340 & & 16.596 & \\
\hline \multicolumn{5}{|c|}{$\begin{array}{l}\text { Model: } E_{i t} / P_{i t-l}=\beta_{0}+\beta_{l} R E T_{i t}+\beta_{2} R D_{i t}+\beta_{3} R E T_{i t} * R D_{i t}+\beta_{4} I F R S_{i t}+\beta_{5} I F R S_{i t} * R E T_{i t} \\
\quad+\beta_{6} I F R S_{i t} * R D_{i t}+\beta_{7} I F R S_{i t} * R E T_{i t} * R D_{i t}+\varepsilon_{i t} \\
\text { The reported } t \text {-statistics are in parentheses and adjusted for heteroscedasticity (White, 1980). } \\
\text { Asterisks denote statistical significance at the } 1 \%(*), 5 \%(* *) \text {, or } 10 \%(* * *) \text { level, respectively. } \\
\text { Variable definitions: } E_{i t} \text { is the earnings per share for firm i in fiscal year } \mathrm{t} ; P_{i t-l} \text { is the price per } \\
\text { share at the beginning of the fiscal year; } R E T_{i t} \text { is the annual return of firm i in fiscal year } \mathrm{t} ; R D_{i t} \text { is } \\
\text { a dummy variable that equals } 1 \text { if } R E T_{i t} \text { is negative, and } 0 \text { otherwise; IFRS is a dummy variable } \\
\text { that takes value } 1 \text { if the financial statements are prepared according to IFRS standards, and } 0 \\
\text { otherwise; and } \varepsilon_{i t} \text { is the error term. }\end{array}$} \\
\hline
\end{tabular}

The results reported in Table 6.18 are qualitatively similar to the main findings.

The coefficients for $R E T^{*} R D$ are positive and significant $(\mathrm{p}<0.01)$ for both samples, showing evidence of earnings conservatism in Malaysia. However, the coefficients for $I F R S^{*} R E T * R D$ for both samples are insignificant $(\mathrm{p}>0.10)$, implying there were no significant changes in the level of earnings conservatism after the adoption of IFRS. All $F$-statistics are significant at the $1 \%$ level, indicating the validity of the models, while adjusted- $R^{2}$ s are between $8 \%$ and $10 \%$, which are identical to the previous analysis. In short, the result fails to provide evidence to infer that the adoption of IFRS reduces or increases the earnings conservatism level, even after reducing the sample to firms with Big Four auditors. 


\subsubsection{Auditors' Industry Specialization}

Auditors' industry specialization has been found to have significant influence on the quality of earnings, in particular earnings conservatism. Krishnan (2005a), for example, finds that firms audited by industry specialists report more conservative earnings than do firms with non-specialist auditors, suggesting that auditors' industry specialization moderates the tendency of the client to delay the recognition of economic losses. In addition, Krishnan (2003) finds clients of industry specialists have significantly lower discretionary accruals than clients of non-specialist auditors.

Given that industry specialists have superior knowledge and resources, it is to be expected they would facilitate a smoother transition to IFRS accounting standards. I restricted the observation to firms audited by industry specialists to control the effect of auditor industry specialization on earnings conservatism. ${ }^{27} \mathrm{I}$ re-estimated equation (5.1) on samples of one year and two years before and after IFRS adoption. The results are reported in Table 6.19.

Similar to the main results, the coefficients for $R E T^{*} R D$ are positive and significant $(\mathrm{p}<0.01)$ for both samples, showing evidence of earnings conservatism in Malaysia. The coefficient for $I F R S^{*} R E T^{*} R D$, which measures significant difference in the levels of earnings conservatism between the pre- and post-IFRS periods, shows mixed results. For the sample of observations one year before and

\footnotetext{
${ }^{27}$ Industry specialist was identified using an industry leader approach, which is identified based on the percentage of clients' total sales audited per total sales of the companies that are listed in the industry (Krishnan, 2003).
} 
after IFRS adoption, the coefficient for IFRS*RET*RD is -0.426 but is insignificant ( $p>0.10$ ), showing no significant difference in earnings conservatism between the two periods. However, the sample of observations two years before and after IFRS adoption, the coefficient for IFRS*RET*RD is -0.403 and significant at the 5\% level ( $p>0.10)$. These results show mixed but weak evidence that in firms audited by an industry specialist, earnings conservatism declines after the adoption of IFRS.

Table 6.19

IFRS Adoption and earnings conservatism: Sample of firms audited by industry specialist

\begin{tabular}{|c|c|c|c|c|}
\hline \multirow{2}{*}{$\begin{array}{c}\text { Sample } \\
\text { Statistics }\end{array}$} & \multicolumn{2}{|c|}{ One Year } & \multicolumn{2}{|c|}{ Two Years } \\
\hline & Coeff & $t$-stat & Coeff & $t$-stat \\
\hline Intercept & $0.157 *$ & (4.997) & $0.093^{*}$ & (3.494) \\
\hline RET & $-0.310^{*}$ & $(-5.491)$ & -0.028 & $(-0.401)$ \\
\hline$R D$ & 0.008 & $(0.142)$ & 0.021 & $(0.448)$ \\
\hline$R E T * R D$ & $0.801 *$ & (4.519) & $0.461 *$ & (3.284) \\
\hline IFRS & $-0.110 * *$ & $(-2.380)$ & -0.017 & $(-0.502)$ \\
\hline$I F R S^{*} R E T$ & $0.430 *$ & (6.149) & $0.135 * * *$ & $(1.818)$ \\
\hline$I F R S * R D$ & 0.008 & $(0.103)$ & -0.047 & $(-0.783)$ \\
\hline$I F R S^{*} R E T^{*} R D$ & -0.426 & $(-1.543)$ & $-0.403 * *$ & $(-2.428)$ \\
\hline $\operatorname{Adj} . R^{2}$ & 0.23 & & 0.14 & \\
\hline$N$ & 291 & & 575 & \\
\hline$F$-stat & 8.808 & & 10.063 & \\
\hline \multicolumn{5}{|c|}{$\begin{array}{l}\text { Model: } E_{i t} / P_{i t-I}=\beta_{0}+\beta_{I} R E T_{i t}+\beta_{2} R D_{i t}+\beta_{3} R E T_{i t} * R D_{i t}+\beta_{4} I F R S_{i t}+\beta_{5} I F R S_{i t} * R E T_{i t} \\
\quad+\beta_{6} I F R S_{i t} * R D_{i t}+\beta_{7} I F R S_{i t} * R E T_{i t} * R D_{i t}+\varepsilon_{i t} \\
\text { The reported } t \text {-statistics are in parentheses and adjusted for heteroscedasticity (White, 1980). } \\
\text { Asterisks denote statistical significance at the } 1 \%(*), 5 \%(* *) \text {, or } 10 \%(* * *) \text { level, respectively. } \\
\text { Variable definitions: } E_{i t} \text { is the earnings per share for firm } \mathrm{i} \text { in fiscal year } \mathrm{t} ; P_{i t-l} \text { is the price per } \\
\text { share at the beginning of the fiscal year; } R E T_{i t} \text { is the annual return of firm i in fiscal year } \mathrm{t} ; R D_{i t} \text { is } \\
\text { a dummy variable that equals } 1 \text { if } R E T_{i t} \text { is negative, and } 0 \text { otherwise; IFRS is a dummy variable } \\
\text { that takes value } 1 \text { if the financial statements are prepared according to IFRS standards, and } 0 \\
\text { otherwise; and } \varepsilon_{i t} \text { is the error term. }\end{array}$} \\
\hline
\end{tabular}




\subsubsection{Time-Series Test of Timeliness in Loss Recognition}

Following Basu (1997) and Ball et al. (2000), I use the time-series test of timeliness in loss recognition as an alternative measure for earnings conservatism. ${ }^{28}$ This model focuses on the extent to which earnings changes reverse, and the extent to which the probability of reversal differs according to whether the previous earnings change was positive or negative. To investigate the impact of IFRS adoption on earnings conservatism, I modified the time-series test of timeliness in loss recognition model to allow examination of incremental reversal of earnings changes from previous year changes of earnings due to IFRS. The modified model is as follows:

$$
\begin{aligned}
\Delta N I_{i t}= & \alpha_{0}+\alpha_{1} \Delta N I_{i t-1}+\alpha_{2} D \Delta N I_{i t-1}+\alpha_{3} \Delta N I_{i t-1} * D \Delta N I_{i t-1}+\alpha_{4} I F R S_{i t-1} \\
& +\alpha_{5} I F R S_{i t-1} * \Delta N I_{i t-1}+\alpha_{6} I F R S_{i t-1} * D \Delta N I_{i t-1} \\
& +\alpha_{7} I_{F R S_{i t-1}} * \Delta N I_{i t-1} * D \Delta N I_{i t-1}+\varepsilon_{i t}
\end{aligned}
$$

where $\Delta N I_{i t}$ is the change in earnings for firm $\mathrm{i}$ from year t-1 to year $\mathrm{t}$, standardised by total assets at end of year t-1;D$\wedge N I_{i t-1}$ is a dummy variable that equals 1 if $\Lambda N I_{i t-1}$ if negative, and 0 otherwise; IFRS is a dummy variable that takes value 1 if the financial statements are prepared according to IFRS standards, and 0 ; and $\varepsilon_{i t}$ is the error term.

Equation (6.1) is the extension for the time-series test of timeliness in loss recognition employed by Basu (1997), which allows IFRS to interact with all

\footnotetext{
28 This test was conducted to overcome this criticism towards the Basu (1997) asymmetric timeliness of earnings model, which was discusses in Section 5.8.1.
} 
variables in the basic model. The coefficient for IFRS*ANI $I_{i t-1} * D \wedge N I_{i t-1}$ tests whether there is a significant difference of the coefficient for $\Delta N I_{i t-1} * D \wedge N I_{i t-1}$, between the pre- and post-adoption of IFRS. The coefficient of $\Delta N I_{i t-1} * D \wedge N I_{i t-1}$ measures the transitory nature of earnings decreases compared to earnings increases, which is a measure for earnings conservatism.

Table 6.20

Time-series test of timeliness in loss recognition: Pre- and post-IFRS adoption

\begin{tabular}{llccc}
\hline \multirow{2}{*}{ Sample } & \multicolumn{2}{c}{ One Year } & \multicolumn{2}{c}{ Two Years } \\
\cline { 2 - 5 } \multicolumn{1}{c}{ Statistics } & \multicolumn{1}{c}{ Coeff } & $t$-stat & Coeff & $t$-stat \\
\hline Intercept & -0.000 & $(-0.079)$ & 0.002 & $(0.578)$ \\
$\Delta N I_{i t-1}$ & $-0.279^{*}$ & $(-3.012)$ & $-0.139^{* *}$ & $(-2.199)$ \\
$D \Delta N I_{i t-1}$ & $-0.015^{* * *}$ & $(-1.735)$ & $-0.016^{* *}$ & $(-2.528)$ \\
$\Delta N I_{i t-1} * D \Delta N I_{i t-1}$ & $-0.535^{* *}$ & $(-2.048)$ & $-0.583^{*}$ & $(-2.992)$ \\
$I F R S_{i t-1}$ & 0.004 & $(0.703)$ & 0.009 & $(1.597)$ \\
$I F R S_{i t-1} * \Delta N I_{i t-1}$ & $0.293^{* *}$ & $(2.378)$ & 0.137 & $(1.104)$ \\
$I F R S_{i t-1} * D \Delta N I_{i t-1}$ & 0.012 & $(0.965)$ & 0.002 & $(0.173)$ \\
$I F R S_{i t-1} * \Delta N I_{i t-1} * D \Delta N I_{i-1-1}$ & -0.321 & $(-0.977)$ & -0.376 & $(-1.494)$ \\
Adj. $^{2}$ & 0.20 & & 0.15 & \\
$N$ & 1040 & & 2079 & \\
$F$-stat & 10.611 & & 17.925 & \\
\hline
\end{tabular}

Model: $\Delta N I_{i t}=\alpha_{0}+\alpha_{1} \Delta N I_{i t-1}+\alpha_{2} D \Delta N I_{i t-1}+\alpha_{3} \wedge N I_{i t-1} * D \wedge N I_{i t-1}+\alpha_{4} I F R S_{i t-1}+\alpha_{5} I F R S_{i t-1} * \Delta N I_{i t-1}$ $+a_{6} I F R S_{i t-1} * D \triangle N I_{i t-1}+a_{7} I F R S_{i t-1} * \triangle N I_{i t-1} * D \triangle N I_{i t-1}+\varepsilon_{i t}$

The sample comprises 2,079 firm-year observations from firms in Bursa Malaysia during 20032008. The reported $t$-statistics are in parentheses and adjusted for heteroscedasticity (White, 1980). Asterisks denote statistical significance at the $1 \%(*), 5 \%(* *)$, or $10 \%(* * *)$ level, respectively. Variable definitions: $\Delta N I_{i t}$ is the change in earnings for firm i from year $\mathrm{t}-1$ to year $\mathrm{t}$, standardised by total assets at end of year t-1;D$\Delta N I_{i t-1}$ is a dummy variable that equals 1 if $\Delta N I_{i t-1}$ if negative, and 0 otherwise; IFRS is a dummy variable that takes value 1 if the financial statements are prepared according to IFRS standards, and 0 ; and $\varepsilon_{i t}$ is the error term.

The regression estimates of equation (6.1) are presented in Table 6.20. The results show that earnings conservatism is a pervasive feature in Malaysian financial reporting. The coefficients for $\Delta N I_{i t-1} * D \Delta N I_{i t-1}$ are negative and significant in both samples, suggesting that the overall negative serial correlation in earnings changes is driven by a reversal of negative earnings changes. However, no significant evidence was found on differences between earnings conservatism for the two 
samples. The coefficients for IFRS* $\triangle N I_{i t-1} * D \wedge N I_{i t-1}$ are negative but not significant $(p>0.10)$, implying there are no significant changes in the extent to which positive earnings changes are more persistent than negative earnings changes after the adoption of IFRS. Thus, the results from the alternative measure for earnings conservatism fails to provide support for the prediction that the adoption of IFRS would affect earnings conservatism.

\subsubsection{Discussion of the Results}

The second objective of this study was to examine the effect of IFRS adoption on earnings conservatism in Malaysia. Given that IFRS standards were made effective from 1 January 2006, this study compares the level of earnings conservatism for one-year and two-year horizons pre- and post-IFRS adoption. Employing the modified Basu (1997) reverse earnings-return regression, I find no significant difference in the level of earnings conservatism between the pre- and post-IFRS adoption periods. To ascertain the sensitivity of the results, various sensitivity analyses were conducted including: (i) controlling for industry and year effects; (ii) reducing the sample to firms with financial year ended 31 December; (iii) restricting the sample to firms with Big Four auditors; (iv) limiting the sample to firms audited by an industry specialist; and (v) employing the time-series test of timeliness in loss recognition model as an alternative measure for earnings conservatism.

This study conjectures that IFRS adoption would affect the level of earnings conservatism since the aims of standards setters' in introducing IFRS is to provide more relevant and neutral information. Given that earnings conservatism, or 
application of higher verification standards in recognising economic losses than economic gains, biases reporting, conservatism is no longer a desirable qualitative characteristic of earnings under IFRS. Contrary to this prediction, the results from the main analysis and the various sensitivity tests show no significant difference in the level of earnings conservatism between pre- and post-IFRS adoption periods.

However, these results provide support for explanations for conservatism such as contracting, litigation, taxation, and regulation factors (Watts, 2003a, 2003b). Any attempt to reduce earnings conservatism would increase the agency cost and the litigation risk, thus market-based mechanisms would require firms to exercise higher verification standards in recognising economic gains than economic losses. Furthermore, these results may be due to the feature of IFRS that limits managers' discretion in choosing accounting alternatives (Devalle, Onali, \& Magarini, 2010). The lack of flexibility in the range of available accounting alternatives may impair the ability of managers to report accounting measures that reflect the underlying economic conditions of a firm (Barth, et al., 2008). Therefore, a priori, it is difficult to determine the effect of IFRS adoption on earnings conservatism.

Overall, this study does not find evidence that IFRS adoption has a significant impact on earnings conservatism. A plausible explanation is that earnings conservatism plays important roles in debt-contracting, minimizing the litigation risk, and enhancing greater monitoring; hence managers, preparers of financial reports, and auditors have greater incentives to report earnings conservatively though the accounting standards warranted unbiased information. As such, this 
study provides evidence for debates on the roles of conservatism, and whether it should indeed be eliminated from financial reporting.

\subsection{Ownership Structure and Earnings Conservatism}

\subsubsection{Introduction}

This section discusses the results of my tests to investigate whether earnings conservatism is influenced by ownership structure. Ownership structure is classified into family firms, state-controlled firms, and widely-held firms. Section 6.5.2 examines differences in earnings conservatism for each type of ownership structure, measured using the timeliness of earnings in recognising good news and bad news. Section 6.5.3 reports the sensitivity analyses such as Fama and MacBeth (1973) estimation, fixed-effects regression, and time-series test of timeliness in loss recognition. In addition, the sensitivity tests include alternative measures for family ownership/control and classification of state-controlled firms into firms under control of the Federal Government of Malaysia and those under the control of States' Governments. Section 6.5.4 reports two additional tests. First, Section 6.5.4.1 reports the test for difference between the earnings conservatism levels of family and widely-held firms. Second, Section 6.5.4.2 reports tests of the relation between strategic control of a family of a firm's management and corporate board influences earnings conservatism. Finally, the overall results for the third hypothesis are summarised in Section 6.5.5 


\subsubsection{Main Analysis: Ownership Structure and Earnings Conservatism}

To examine differences between earnings conservatism for firms with different ownership structure, I estimated equation (5.1) on three samples: family firms, state-controlled firms and widely-held firms. The regression estimates are reported in Table 6.21. Panel A (Panel B) presents the regression estimates for the timeliness of good news (bad news), while Panel $\mathrm{C}$ reports the asymmetric timeliness of earnings between the good news and bad news samples.

The results reported in Panel A show that the coefficients for RET in family firms and state-controlled firms are positive and significant at the $1 \%$ level, implying that both types of firms recognise good news in a timely manner. For widely-held firms, the coefficient for $R E T$ is not significant ( $p>0.10$ ), showing no evidence of timeliness of earnings in recognising good news in those firms.

For the bad news sample, the results reported in Panel B show that bad news is recognised in a timely fashion in family firms and widely-held samples, but not in state-controlled firms. The coefficient values for RET in family firms and widelyheld firms are 0.292 and 0.213 , both significant at the $1 \%$ level, implying evidence of timely recognition of bad news. However, the coefficient for RET in state-controlled firms is not significant $(\mathrm{p}>0.10)$, suggesting that state-controlled firms delay the recognition of bad news. From both Panel A and Panel B, the results show that family firms are timely in recognising both types of economic news, while widely-held firms are timely in recognition of bad news but not good news. Contrary to family firms and widely-held firms, good news appears to be recognised in a more timely fashion than is bad news in state-controlled firms, 
showing no evidence of conservatism.

Table 6.21

Ownership structure and earnings conservatism

Panel A: Timeliness of earnings in good news sample

\begin{tabular}{lcccccc}
\hline \multicolumn{1}{c}{ Sample } & \multicolumn{2}{c}{ Family } & \multicolumn{2}{c}{ State-Controlled } & \multicolumn{2}{c}{ Widely-Held } \\
\multicolumn{1}{c}{ Statistics } & Coeff & $t$-stat & Coeff & $t$-stat & Coeff & $t$-stat \\
\hline Intercept & $0.059^{*}$ & $(5.232)$ & $0.086^{*}$ & $(7.230)$ & $0.040^{* *}$ & $(2.358)$ \\
$R E T$ & $0.091^{*}$ & $(6.053)$ & $0.074^{*}$ & $(3.918)$ & 0.028 & $(0.933)$ \\
Adj. $R^{2}$ & 0.09 & & 0.10 & & 0.01 & \\
$N$ & 854 & & 136 & & 568 & \\
$F$-stat & 36.636 & & 15.354 & & 0.870 & \\
\hline
\end{tabular}

Panel B: Timeliness of earnings in bad news sample

\begin{tabular}{lcccccc}
\hline \multicolumn{1}{c}{ Sample } & \multicolumn{2}{c}{ Family } & \multicolumn{2}{c}{ State-Controlled } & \multicolumn{2}{c}{ Widely-Held } \\
\multicolumn{1}{c}{ Statistics } & Coeff & $t$-stat & Coeff & $t$-stat & Coeff & $t$-stat \\
\hline Intercept & $0.074^{*}$ & $(4.485)$ & $0.081^{*}$ & $(3.167)$ & $0.034^{* * *}$ & $(1.770)$ \\
$R E T$ & $0.292^{*}$ & $(5.678)$ & 0.163 & $(1.538)$ & $0.213^{*}$ & $(4.097)$ \\
Adj. $R^{2}$ & 0.03 & & 0.03 & & 0.02 & \\
$N$ & 916 & & 98 & & 554 & \\
$F$-stat & 32.241 & & 2.364 & & 16.786 & \\
\hline
\end{tabular}

Panel C: The asymmetric timeliness of earnings

\begin{tabular}{|c|c|c|c|c|c|c|}
\hline \multirow{2}{*}{$\begin{array}{c}\text { Sample } \\
\text { Statistics }\end{array}$} & \multicolumn{2}{|c|}{ Family } & \multicolumn{2}{|c|}{ State-Controlled } & \multicolumn{2}{|c|}{ Widely-Held } \\
\hline & Coeff & $t$-stat & Coeff & $t$-stat & Coeff & $t$-stat \\
\hline Intercept & $0.059 *$ & $(5.232)$ & $0.086 *$ & $(7.221)$ & $0.040 * *$ & $(2.357)$ \\
\hline$R E T$ & $0.091 *$ & $(6.053)$ & $0.074 *$ & (3.914) & 0.028 & $(0.933)$ \\
\hline$R D$ & 0.014 & $(0.724)$ & -0.005 & $(-0.166)$ & -0.006 & $(-0.247)$ \\
\hline$R E T^{*} R D$ & $0.201 *$ & $(3.747)$ & 0.089 & $(0.826)$ & $0.185^{*}$ & $(3.093)$ \\
\hline $\operatorname{Adj} . R^{2}$ & 0.10 & & 0.14 & & 0.04 & \\
\hline$N$ & 1770 & & 234 & & 1122 & \\
\hline$F$-stat & 43.233 & & 11.749 & & 15.240 & \\
\hline \multicolumn{7}{|c|}{$\begin{array}{l}\text { Model: } E_{i t} / P_{i t-1}=\beta_{0}+\beta_{1} R E T_{i t}+\beta_{2} R D_{i t}+\beta_{3} R E T_{i t} * R D_{i t}+\varepsilon_{i t} \\
\text { The sample comprises } 3,126 \text { firm-year observations from firms in Bursa Malaysia during 2003- } \\
\text { 2008. The reported } t \text {-statistics are in parentheses and adjusted for heteroscedasticity (White, 1980). } \\
\text { Asterisks denote statistical significance at the } 1 \%(*), 5 \%(* *) \text {, or } 10 \%(* * *) \text { level, respectively. } \\
\text { Variable definitions: } E_{i t} \text { is the earnings per share for firm } \mathrm{i} \text { in fiscal year } \mathrm{t} ; P_{i t-1} \text { is the price per } \\
\text { share at the beginning of the fiscal year; } R E T_{i t} \text { is the annual return of firm } \mathrm{i} \text { in fiscal year } \mathrm{t} ; R D_{i t} \text { is } \\
\text { a dummy variable that equals } 1 \text { if } R E T_{i t} \text { is negative, and } 0 \text { otherwise; and } \varepsilon_{i t} \text { is the error term. }\end{array}$} \\
\hline
\end{tabular}

The results for difference between the timeliness of earnings in recognition of 
good news and bad news are reported in Panel C. The regression estimates, from the Basu (1997) reverse earnings-return regression, contain evidence of earnings conservatism in family firms and widely-held firms. The coefficient for $R E T * R D$, which measures the difference or the increment in the timeliness of earnings in recognising bad news compared to good news, are 0.201 and 0.185 in family firms and widely-held firms respectively, and significant at the $1 \%$ level. These results imply evidence of earnings conservatism in family firms and wide-held firms. For state-controlled firms, the coefficient for $R E T^{*} R D$ is not significant ( $p>0.10$ ), and no evidence of earnings conservatism was found.

Overall, the results show that ownership structure has a significant influence on the level of earnings conservatism. A plausible explanation is that the incentives and demands for conservative reporting vary due to the different levels of agency costs and information asymmetry applicable to each type of ownership structure. With regard to family firms, the findings support the proposition that significant family control of a firm exerts greater monitoring and provides greater incentive to produce high-quality earnings, i.e. earnings conservatism. The evidence is consistent with Wang (2006), who documents that founding family ownership in the United States is associated with higher earnings quality, in particular lower abnormal accruals, greater earnings informativeness, and less persistence of transitory loss components in earnings. Indirectly, this study provides evidence of alignment effects in family firms. For state-controlled firms, the evidence from this study is consistent with Bushman and Piotroski (2006), where in common-law countries firms facing high state involvement in the economy tend to speed the recognition of good news and slow the recognition of bad news relative to firms in 
countries with less state involvement. The plausible explanation is that the government might intervene in poorly-performing state-controlled firms, and managers are inclined to avoid such interference by exploiting reporting discretion to portray an optimistic outlook (Bushman \& Piotroski, 2006). Furthermore, statecontrolled firms were pressured by the government to upwardly tilt their reporting decisions (Bushman \& Piotroski, 2006).

\subsubsection{Sensitivity Analysis}

I performed various robustness tests to test the robustness of the main results. First, in Section 6.5.3.1, I use the Fama and MacBeth estimation. Second, I control for industry and year effects in Section 6.5.3.2. Third, I employed timeseries test of loss recognition, the results of which are reported in Section 6.5.3.3. Fourth, I use different definitions for family firms; and the regression estimates are reported in Section 6.5.3.4. Finally, in Section 6.5.3.5, I partition the statecontrolled firms into Federal-Government-controlled firms and non-FederalGovernment-controlled firms.

\subsubsection{Fama and MacBeth (1973)}

I re-estimated the Basu (1997) reverse earnings-return regression using Fama and MacBeth's (1973) procedure on family firms, state-controlled firms, and widelyheld firms to control for cross-sectional dependence problems. The estimation results are presented in Table 6.22.

Consistent with the main results, regression estimates in Table 6.22 show 
evidence of earnings conservatism in family firms and widely-held firms. The coefficient for $R E T^{*} R D$ in family firms is 0.313 and significant at the $1 \%$ level, implying more timely recognition of economic losses and economic gains. The coefficient for RET is also positive and significant ( $\mathrm{p}<0.01)$, suggesting timely recognition of good news. These results show that in family firms, both bad news and good news are recognised in a timely way in earnings, but the recognition speed is faster in the case of bad news.

Table 6.22

Ownership structure and earnings conservatism: Fama and MacBeth (1973) annual regression

\begin{tabular}{lcccccc}
\hline \multicolumn{1}{c}{ Sample } & \multicolumn{2}{c}{ Family } & \multicolumn{2}{c}{ State-Controlled } & \multicolumn{2}{c}{ Widely-Held } \\
\multicolumn{1}{c}{ Statistics } & Coeff & $t$-stat & Coeff & $t$-stat & Coeff & $t$-stat \\
\hline Intercept & $0.077^{*}$ & $(4.057)$ & $0.085^{*}$ & $(7.993)$ & $0.047 * * *$ & $(2.185)$ \\
$R E T$ & $0.075^{*}$ & $(4.306)$ & $0.082^{* * *}$ & $(2.422)$ & 0.026 & $(0.914)$ \\
$R D$ & 0.008 & $(0.428)$ & -0.008 & $(-0.152)$ & 0.006 & $(0.304)$ \\
$R E T * R D$ & $0.313^{*}$ & $(4.971)$ & 0.116 & $(0.649)$ & $0.343 * * *$ & $(2.464)$ \\
Adj.R & 0.14 & & 0.21 & & 0.08 & \\
$N$ & 1770 & & 234 & & 1122 & \\
$F$-stat & 56.592 & & 36.999 & & 10.253 & \\
\hline
\end{tabular}

Model: $E_{i t} / P_{i t-l}=\beta_{0}+\beta_{1} R E T_{i t}+\beta_{2} R D_{i t}+\beta_{3} R E T_{i t} * R D_{i t}+\varepsilon_{i t}$

The sample comprises 3,126 firm-year observations from firms in Bursa Malaysia during 20032008. I use the Fama and MacBeth (1973) methodology to cope with the possible cross-sectional dependence problems. The coefficients of the parameters have been obtained as the simple average from the cross-sectional regression. The $t$-statistics are the ratios of the mean estimated Coefficients to the standard deviation of the distribution of the annual estimated slope Coefficients, divided by the square root of the number of years. Asterisks denote statistical significance at the $1 \%(*), 5 \%(* *)$, or $10 \%(* * *)$ level, respectively. Variable definitions: $E_{i t}$ is the earnings per share for firm $\mathrm{i}$ in fiscal year $\mathrm{t} ; P_{i t-l}$ is the price per share at the beginning of the fiscal year; $R E T_{i t}$ is the annual return of firm i in fiscal year $\mathrm{t} ; R D_{i t}$ is a dummy variable that equals 1 if $R E T_{i t}$ is negative, and 0 otherwise; and $\varepsilon_{i t}$ is the error term.

With regard to the widely-held sample, the results show a qualitatively similar result to the earlier analysis. The coefficient for $R E T * R D$ is positive $(0.343)$ and significant at the $10 \%$ level, showing little evidence of earnings conservatism in widely-held firms. However, the coefficient for RET is not significant, implying no evidence of the timeliness of earnings towards good news. For state-controlled 
firms, the results from Fama and MacBeth estimation show that the coefficient for $R E T$ is positive and significant $(\mathrm{p}<0.10)$, implying timely recognition of good news; however, the coefficient of $R E T * R D$ is not significant, indicating lack of evidence to assert the presence of earnings conservatism in state-controlled firms. In short, the results reported in Table 6.22, based on Fama and MacBeth (1973), support the main results.

\subsubsection{Industry and Year Effects}

In this section, I re-estimated equation (5.1) using fixed-effects regression that incorporated industry and year dummies. This procedure was undertaken to control the serial correlation problem of the residual of panel data in the Basu (1997) reverse earnings-return regression. The regression estimates for family firms, state-controlled firms, and widely-held firms are summarised in Table 6.23.

The results show that the coefficients for RET for all types of firms are positive and significant, implying timely recognition of good news. However, the incremental timeliness of bad news, earnings conservatism, is found only in family firms and widely-held firms. The coefficients for $R E T^{*} R D$ in family firms and widely-held firms are 0.285 and 0.264 , respectively, and significant at the $1 \%$ level, implying evidence for earnings conservatism in both family firms and widely-held firms. For state-controlled firms, no evidence of earnings conservatism is documented since the coefficient for $R E T * R D$ is not significant (p>0.10). All $F$-statistics are significant at the $1 \%$ level, showing the validity of the results. In short, the main findings are robust even after controlling for industry and year effects. 
Table 6.23

Ownership structure and earnings conservatism: Estimation controlling for industry and year effects

\begin{tabular}{|c|c|c|c|c|c|c|}
\hline \multirow{2}{*}{$\begin{array}{c}\text { Sample } \\
\text { Statistics }\end{array}$} & \multicolumn{2}{|c|}{ Family } & \multicolumn{2}{|c|}{ State-Controlled } & \multicolumn{2}{|c|}{ Widely-Held } \\
\hline & Coeff & $t$-stat & Coeff & $t$-stat & Coeff & $t$-stat \\
\hline Intercept & 0.029 & $(0.960)$ & $0.167 *$ & $(4.912)$ & -0.049 & $(-1.240)$ \\
\hline RET & $0.088^{*}$ & (9.427) & $0.057^{*}$ & (2.794) & $0.025 * * *$ & (1.864) \\
\hline$R D$ & 0.005 & $(0.247)$ & -0.009 & $(-0.370)$ & -0.011 & $(-0.408)$ \\
\hline$R E T * R D$ & $0.285^{*}$ & $(5.171)$ & 0.106 & $(1.365)$ & $0.264 *$ & $(4.166)$ \\
\hline CONS & -0.001 & $(-0.031)$ & $-0.104 *$ & $(-3.039)$ & 0.055 & (1.369) \\
\hline HOTEL & $-0.145^{* * *}$ & $(-1.698)$ & & & 0.109 & (1.267) \\
\hline$I P C$ & 0.067 & $(0.788)$ & $-0.351^{*}$ & $(-6.473)$ & 0.116 & (1.349) \\
\hline IPROD & 0.027 & (1.002) & $-0.100^{*}$ & $(-3.053)$ & $0.077^{* *}$ & (2.116) \\
\hline PLANT & -0.027 & $(-0.739)$ & & & $0.100^{* *}$ & (2.110) \\
\hline PROP & -0.034 & $(-1.122)$ & $-0.094 *$ & $(-2.746)$ & $0.086^{* *}$ & (2.027) \\
\hline TECH & 0.043 & $(0.935)$ & & & 0.060 & (1.161) \\
\hline$T D G$ & -0.023 & $(-0.770)$ & $-0.089^{*}$ & $(-3.053)$ & $0.103^{*}$ & (2.738) \\
\hline Y2004 & 0.021 & $(0.902)$ & -0.007 & $(-0.274)$ & 0.002 & $(0.059)$ \\
\hline Y2005 & $0.091^{*}$ & (3.808) & 0.021 & $(0.770)$ & 0.037 & $(1.275)$ \\
\hline Y2006 & 0.003 & $(0.121)$ & 0.024 & $(0.921)$ & -0.032 & $(-1.119)$ \\
\hline Y2007 & $0.051 * *$ & $(2.178)$ & 0.028 & (1.099) & 0.043 & $(1.512)$ \\
\hline Y2008 & $0.123 *$ & $(5.035)$ & 0.042 & $(1.432)$ & $0.107 *$ & $(3.545)$ \\
\hline $\operatorname{Adj} . R^{2}$ & 0.13 & & 0.26 & & 0.05 & \\
\hline$N$ & 1770 & & 234 & & 1122 & \\
\hline$F$-stat & 16.898 & & 7.425 & & 5.077 & \\
\hline \multicolumn{7}{|c|}{$\begin{array}{l}\text { Model: } E_{i t} / P_{i t-l}=\beta_{0}+\beta_{l} R E T_{i t}+\beta_{2} R D_{i t}+\beta_{3} R E T_{i t} * R D_{i t}+\text { Industry }+ \text { Year }+\varepsilon_{i t} \\
\text { The sample comprises } 3,126 \text { firm-year observations from firms in Bursa Malaysia during 2003- } \\
\text { 2008. The reported } t \text {-statistics are in parentheses and adjusted for heteroscedasticity (White, 1980). } \\
\text { Asterisks denote statistical significance at the } 1 \%(*), 5 \%(* *) \text {, or } 10 \%(* * *) \text { level, respectively. } \\
\text { Variable definitions: } E_{i t} \text { is the earnings per share for firm i in fiscal year } \mathrm{t} ; P_{i t-1} \text { is the price per } \\
\text { share at the beginning of the fiscal year; } R E T_{i t} \text { is the annual return of firm i in fiscal year } \mathrm{t} ; R D_{i t} \text { is } \\
\text { a dummy variable that equals } 1 \text { if } R E T_{i t} \text { is negative, and } 0 \text { otherwise; Industry are dummy variables } \\
\text { for Bursa Malaysia industry sectors; Year are dummy variables for fiscal years; and } \varepsilon_{i t} \text { is the error } \\
\text { term. }\end{array}$} \\
\hline
\end{tabular}

\subsubsection{Time-Series Test of Timeliness in Loss Recognition}

In this section, I estimated the time-series test of timeliness in loss recognition as an alternative measure for earnings conservatism, in order to ascertain the 
robustness of the earlier results. ${ }^{29}$ Table 6.24 presents the regression estimates from the time-series test of timeliness in loss recognition for family firms, statecontrolled firms, and widely-held firms.

Table 6.24

Ownership structure and time-series test of timeliness in loss recognition

\begin{tabular}{lcccccc}
\hline \multicolumn{1}{c}{ Sample } & \multicolumn{2}{c}{ Family } & \multicolumn{2}{c}{ State-Controlled } & \multicolumn{2}{c}{ Widely-Held } \\
\multicolumn{1}{c}{ Statistics } & Coeff & $t$-stat & Coeff & $t$-stat & Coeff & $t$-stat \\
\hline Intercept & $0.008^{*}$ & $(2.822)$ & 0.005 & $(0.669)$ & 0.005 & $(1.130)$ \\
$\Delta N I_{i t-1}$ & $-0.166^{*}$ & $(-2.783)$ & -0.254 & $(-1.084)$ & -0.042 & $(-0.439)$ \\
$D \Delta N I_{i t-1}$ & $-0.016^{*}$ & $(-3.238)$ & -0.008 & $(-0.737)$ & $-0.020^{*}$ & $(-2.808)$ \\
$\Delta N I_{i t-1} * D \Delta N I_{i t-1}$ & $-0.608^{*}$ & $(-4.506)$ & -0.578 & $(-1.484)$ & $-0.836^{*}$ & $(-4.781)$ \\
$A d j . R^{2}$ & 0.14 & & 0.20 & & 0.13 & \\
$N$ & 1762 & & 229 & & 1114 & \\
$F$-stat & 19.098 & & 4.254 & & 12.631 & \\
\hline
\end{tabular}

Model: $\Delta N I_{i t}=\alpha_{0}+\alpha_{1} \Delta N I_{i t-1}+\alpha_{2} D \Delta N I_{i t-1}+\alpha_{3} \Delta N I_{i t-1} * D \Delta N I_{i t-1}+$ industry + year $+\varepsilon_{i t}$

The sample comprises 3,105 firm-year observations from firms in Bursa Malaysia during 20032008. The reported $t$-statistics are in parentheses and adjusted for heteroscedasticity (White, 1980). Asterisks denote statistical significance at the $1 \%(*), 5 \%(* *)$, or $10 \%(* * *)$ level, respectively. Variable definitions: $\Delta N I_{i t}$ is the change in earnings for firm i from year $\mathrm{t}-1$ to year $\mathrm{t}$, standardised by total assets at end of year t-1;D$D N I_{i t-1}$ is a dummy variable that equals 1 if $\Delta N I_{i t-l}$ if negative, and 0 otherwise; and $\varepsilon_{i t}$ is the error term.

The regression estimates for family firms and widely-held firms denote that earnings decreases are much less persistent (more transitory) than their increases. The coefficients for $\Delta N I_{i t-1} * D \wedge N I_{i t-1}$ for family firms and widely-held firms are 0.608 and -0.836 respectively, and both are significant at the $1 \%$ level. This shows that earnings reflect economic losses more quickly than it reflects economic profits in family firms and widely-held firms. For state-controlled firms, no evidence of earnings conservatism was found as the coefficient for $\triangle N I_{i t-1} * D \wedge N I_{i t-}$ $l$ is not significant, suggesting that earnings decreases are much less persistent

\footnotetext{
${ }^{29}$ The sample sizes are reduced because of the additional data requirements to calculate income changes in two consecutive years.
} 
(more transitory) than earnings increases. These results are also consistent with the main result based on the asymmetric timeliness of earnings model. Furthermore, the $F$-statistics in all sub-samples are significant at the $1 \%$ level, showing the validity of the model.

\subsubsection{Alternative Measures for Family Firms}

In this section, I employ two alternative measures for family firms to test whether the evidence of earnings conservatism in family firms in the analysis above is sensitive to altewrnative definitions. For the first measure, family firms can be either (i) firms with at least two members of the controlling family on the board of directors; or (ii) firms in which the largest shareholder, either an individual, a family, or a private firm, owns more than $20 \%$ of the shares. This definition is based on Faccio and Lang (2002), Arosa, Iturralde, and Maseda (2010), La Porta et al. (1999) and Villalonga and Amit (2006).

For the second measure, I employed a stricter definition for family firms by increasing the minimum threshold for the largest shareholder, whether an individual, a family, or a private firm, to 30. In addition, the board of directors must comprise at least two members from the controlling family. In terms of sample size, the number of observations increases from 1,770 in the main sample to 2,310 firm-year observations in the first alternative measure for family firms; while for the second measure, the number of firm-year observations in the sample decreases to 1,176 firm-year observations.

I re-estimated equation (5.1) using the basic pooled regression, Fama and 
MacBeth (1973) annual regression, and fixed-effects regression. The results are summarised in Table 6.25(a) and 6.25(b).

Table 6.25(a)

Ownership structure and earnings conservatism: Alternative definitions for family firms and various specifications (Board presence or more than $20 \%$ shares)

\begin{tabular}{|c|c|c|c|c|c|c|}
\hline \multirow{2}{*}{$\begin{array}{c}\text { Model } \\
\text { Statistics }\end{array}$} & \multicolumn{2}{|c|}{ Basic } & \multicolumn{2}{|c|}{ Fama-MacBeth } & \multicolumn{2}{|c|}{ Fixed Effects } \\
\hline & Coeff & $t$-stat & Coeff & $t$-stat & Coeff & $t$-stat \\
\hline Intercept & $0.051^{*}$ & $(6.321)$ & $0.066^{* *}$ & (3.830) & 0.009 & $(0.453)$ \\
\hline RET & $0.081^{*}$ & (5.958) & $0.066^{* *}$ & $(2.848)$ & $0.078^{*}$ & (8.183) \\
\hline$R D$ & 0.018 & (1.408) & 0.010 & $(0.821)$ & 0.012 & $(0.925)$ \\
\hline$R E T * R D$ & $0.168^{*}$ & $(4.879)$ & $0.259 *$ & (5.026) & $0.231^{*}$ & $(6.562)$ \\
\hline CONS & & & & & 0.007 & $(0.361)$ \\
\hline HOTEL & & & & & -0.062 & $(-1.254)$ \\
\hline$I P C$ & & & & & 0.088 & $(1.478)$ \\
\hline IPROD & & & & & 0.026 & (1.523) \\
\hline PLANT & & & & & 0.032 & (1.408) \\
\hline PROP & & & & & 0.007 & $(0.393)$ \\
\hline TECH & & & & & 0.008 & $(0.312)$ \\
\hline$T D G$ & & & & & 0.012 & $(0.653)$ \\
\hline Y2004 & & & & & $0.026 * * *$ & (1.814) \\
\hline Y2005 & & & & & $0.067^{*}$ & (4.479) \\
\hline Y2006 & & & & & 0.002 & $(0.130)$ \\
\hline Y2007 & & & & & $0.044^{*}$ & $(3.052)$ \\
\hline Y2008 & & & & & $0.097 *$ & (6.342) \\
\hline $\operatorname{Adj} . R^{2}$ & 0.10 & & 0.13 & & 0.12 & \\
\hline$N$ & 2310 & & 2310 & & 2310 & \\
\hline$F$-stat & 61.076 & & 59.950 & & 20.469 & \\
\hline
\end{tabular}

Model: $E_{i l} / P_{i t-1}=\beta_{0}+\beta_{1} R E T_{i t}+\beta_{2} R D_{i t}+\beta_{3} R E T_{i t} * R D_{i t}+$ Industry + Year $+\varepsilon_{i t}$

The sample comprises 2,310 firm-year observations from firms in Bursa Malaysia during 20032008. The reported $t$-statistics are in parentheses and adjusted for heteroscedasticity (White, 1980). Asterisks denote statistical significance at the $1 \%(*), 5 \%(* *)$, or $10 \%(* * *)$ level, respectively. Variable definitions: $E_{i t}$ is the earnings per share for firm i in fiscal year $\mathrm{t} ; P_{i t-1}$ is the price per share at the beginning of the fiscal year; $R E T_{i t}$ is the annual return of firm i in fiscal year $\mathrm{t} ; R D_{i t}$ is a dummy variable that equals 1 if $R E T_{i t}$ is negative, and 0 otherwise; Industry are dummy variables for Bursa Malaysia industry sectors; Year are dummy variables for fiscal years; and $\varepsilon_{i t}$ is the error term. 
Table 6.25(b)

Ownership structure and earnings conservatism: Alternative definitions for family firms and various specifications (Board Presence and More than 30\% shares)

\begin{tabular}{|c|c|c|c|c|c|c|}
\hline \multirow{2}{*}{$\begin{array}{c}\text { Model } \\
\text { Statistics }\end{array}$} & \multicolumn{2}{|c|}{ Basic } & \multicolumn{2}{|c|}{ Fama-MacBeth } & \multicolumn{2}{|c|}{ Fixed Effects } \\
\hline & Coeff & $t$-stat & Coeff & $t$-stat & Coeff & $t$-stat \\
\hline Intercept & $0.076^{*}$ & $(8.052)$ & $0.084 *$ & (5.675) & 0.013 & $(0.519)$ \\
\hline$R E T$ & $0.093^{*}$ & (5.441) & $0.095^{*}$ & $(7.280)$ & $0.095^{*}$ & (7.974) \\
\hline$R D$ & 0.017 & (1.078) & 0.015 & (1.097) & 0.009 & $(0.550)$ \\
\hline$R E T * R D$ & $0.175^{*}$ & $(3.470)$ & $0.238 * *$ & (3.545) & $0.215^{*}$ & (4.689) \\
\hline CONS & & & & & 0.038 & $(1.561)$ \\
\hline HOTEL & & & & & 0.027 & $(0.351)$ \\
\hline$I P C$ & & & & & 0.071 & $(0.944)$ \\
\hline IPROD & & & & & $0.056^{* *}$ & (2.369) \\
\hline PLANT & & & & & 0.011 & $(0.353)$ \\
\hline$P R O P$ & & & & & 0.027 & (1.049) \\
\hline TECH & & & & & -0.008 & $(-0.165)$ \\
\hline$T D G$ & & & & & 0.003 & $(0.113)$ \\
\hline Y2004 & & & & & 0.021 & (1.163) \\
\hline Y2005 & & & & & $0.066^{*}$ & (3.588) \\
\hline Y2006 & & & & & 0.024 & (1.329) \\
\hline Y2007 & & & & & $0.033^{* * *}$ & (1.846) \\
\hline Y2008 & & & & & $0.086^{*}$ & (4.596) \\
\hline $\operatorname{Adj} . R^{2}$ & 0.14 & & 0.17 & & 0.16 & \\
\hline$N$ & 1176 & & 1176 & & 1176 & \\
\hline$F$-stat & 39.414 & & 24.616 & & 14.972 & \\
\hline \multicolumn{7}{|c|}{$\begin{array}{l}\text { Model: } E_{i t} / P_{i t-1}=\beta_{0}+\beta_{1} R E T_{i t}+\beta_{2} R D_{i t}+\beta_{3} R E T_{i t} * R D_{i t}+\text { Industry }+ \text { Year }+\varepsilon_{i t} \\
\text { The sample comprises } 1,176 \text { firm-year observations from firms in Bursa Malaysia during 2003- } \\
\text { 2008. The reported } t \text {-statistics are in parentheses and adjusted for heteroscedasticity (White, 1980). } \\
\text { Asterisks denote statistical significance at the } 1 \%(*), 5 \%(* *) \text {, or } 10 \%(* * *) \text { level, respectively. } \\
\text { Variable definitions: } E_{i t} \text { is the earnings per share for firm i in fiscal year } \mathrm{t} ; P_{i t-1} \text { is the price per } \\
\text { share at the beginning of the fiscal year; } R E T_{i t} \text { is the annual return of firm i in fiscal year } t R D_{i t} \text { is } \\
\text { a dummy variable that equals } 1 \text { if } R E T_{i t} \text { is negative, and } 0 \text { otherwise; Industry are dummy variables } \\
\text { for Bursa Malaysia industry sectors; Year are dummy variables for fiscal years; and } \varepsilon_{i t} \text { is the error } \\
\text { term. }\end{array}$} \\
\hline
\end{tabular}

Table 6.25(a) presents regression estimates on the sample derived from the first alternative measure of family firms. The results denote qualitatively similar results to those in the main analysis. The coefficients for RET are positively significant in all three models, suggesting that earnings are timely in the recognition of good news. The coefficients for $R E T * R D$ for the basic pooled regression, Fama and MacBeth (1973) annual regression, and fixed-effects 
regression are $0.168,0.259$, and 0.231 , respectively, and significant at the $1 \%$ level, implying earnings reflect bad news in a more timely manner than good news.

The results reported in Table 6.25(b) also show qualitatively similar results to those reported in the main analysis, in which earnings conservatism is a pervasive feature in family firms. The coefficients for $R E T * R D$ are positive and significant $(\mathrm{p}<0.01)$ in all models, implying a more timely recognition of economic losses than economic gains in family firms.

\subsubsection{State-Controlled Firms: Federal and States' Firms}

In the main results, I find no evidence of earnings conservatism in state-controlled firms. Specifically, state-controlled firms are timely in the recognition of good news but not in the recognition of bad news; hence the results do not provide evidence of earnings conservatism in state-controlled firms. In this section, I further examine whether the main results differ when the sample is divided into firms under control of the Federal Government of Malaysia on the one hand and State Governments on the other. I employed this classification because the monitoring mechanisms for state-controlled firms vary according to firm ownership. For firms under the control of the Federal Government, Khazanah Nasional monitors and assesses the performance of directors. In addition, the Putrajaya Committee on GLC High Performance (PCG) conducts the transformation plan to enhance the performance of these firms. Firms under the

control of State Governments are managed and controlled through the State Economic Development Corporation (SEDC), which has limited resources 
compared to the Khazanah Nasional.

Table 6.26(a)

Earnings conservatism in Firms under control of the Federal Government of Malaysia: Various specifications

\begin{tabular}{|c|c|c|c|c|c|c|}
\hline \multirow[b]{2}{*}{ Variable } & \multicolumn{2}{|c|}{ Basic } & \multicolumn{2}{|c|}{ Fama-MacBeth } & \multicolumn{2}{|c|}{ Fixed Effects } \\
\hline & Coeff & $t$-stat & Coeff & $t$-stat & Coeff & $t$-stat \\
\hline Intercept & $0.075^{*}$ & (6.940) & $0.074 *$ & (6.028) & $-0.213^{*}$ & $(-4.578)$ \\
\hline RET & $0.098^{*}$ & (3.307) & $0.099^{* *}$ & (3.518) & $0.086^{*}$ & $(3.380)$ \\
\hline$R D$ & -0.005 & $(-0.130)$ & -0.014 & $(-0.272)$ & -0.017 & $(-0.656)$ \\
\hline$R E T * R D$ & 0.100 & $(0.513)$ & 0.085 & $(0.300)$ & -0.022 & $(-0.233)$ \\
\hline CONS & & & & & $0.276^{*}$ & $(6.167)$ \\
\hline \multicolumn{7}{|l|}{ HOTEL } \\
\hline \multicolumn{7}{|l|}{$I P C$} \\
\hline IPROD & & & & & $0.257 *$ & (5.903) \\
\hline PLANT & & & & & $0.383^{*}$ & (6.828) \\
\hline \multicolumn{7}{|l|}{ PROP } \\
\hline \multicolumn{7}{|l|}{ TECH } \\
\hline$T D G$ & & & & & $0.268^{*}$ & (6.297) \\
\hline Y2004 & & & & & 0.027 & $(0.957)$ \\
\hline Y2005 & & & & & 0.042 & (1.468) \\
\hline Y2006 & & & & & 0.038 & (1.318) \\
\hline Y2007 & & & & & 0.017 & $(0.596)$ \\
\hline Y2008 & & & & & 0.020 & $(0.687)$ \\
\hline $\operatorname{Adj} . R^{2}$ & 0.19 & & 0.37 & & 0.41 & \\
\hline$N$ & 132 & & 132 & & 132 & \\
\hline$F$-stat & 7.314 & & 5.243 & & 8.479 & \\
\hline
\end{tabular}

Model: $E_{i t} / P_{i t-1}=\beta_{0}+\beta_{1} R E T_{i t}+\beta_{2} R D_{i t}+\beta_{3} R E T_{i t} * R D_{i t}+$ Industry + Year $+\varepsilon_{i t}$

The sample comprises 132 firm-year observations from firms in Bursa Malaysia during 20032008. The reported $t$-statistics are in parentheses and adjusted for heteroscedasticity (White, 1980). Asterisks denote statistical significance at the $1 \%(*), 5 \%(* *)$, or $10 \%(* *)$ level, respectively. Variable definitions: $E_{i t}$ is the earnings per share for firm i in fiscal year $\mathrm{t} ; P_{i t-l}$ is the price per share at the beginning of the fiscal year; $R E T_{i t}$ is the annual return of firm i in fiscal year $\mathrm{t} ; R D_{i t}$ is a dummy variable that equals 1 if $R E T_{i t}$ is negative, and 0 otherwise; Industry are dummy variables for Bursa Malaysia industry sectors; Year are dummy variables for fiscal years; and $\varepsilon_{i t}$ is the error term. 
Table 6.26(b)

Earnings conservatism in Firms under control of State Governments: Various specifications

\begin{tabular}{|c|c|c|c|c|c|c|}
\hline \multirow[b]{2}{*}{ Variable } & \multicolumn{2}{|c|}{ Basic } & \multicolumn{2}{|c|}{ Fama-MacBeth } & \multicolumn{2}{|c|}{ Fixed Effects } \\
\hline & Coeff & $t$-stat & Coeff & $t$-stat & Coeff & $t$-stat \\
\hline Intercept & $0.099 *$ & $(3.822)$ & 0.062 & (1.846) & 0.028 & $(0.447)$ \\
\hline$R E T$ & $0.053 * *$ & (2.035) & 0.143 & $(1.740)$ & 0.021 & $(0.631)$ \\
\hline$R D$ & 0.014 & $(0.383)$ & 0.085 & (1.735) & 0.040 & $(0.760)$ \\
\hline$R E T^{*} R D$ & 0.143 & (1.223) & 0.233 & (1.120) & $0.278 * *$ & (2.014) \\
\hline \multicolumn{7}{|l|}{ CONS } \\
\hline \multicolumn{7}{|l|}{ HOTEL } \\
\hline \multicolumn{7}{|l|}{$I P C$} \\
\hline IPROD & & & & & 0.088 & (1.327) \\
\hline PLANT & & & & & $0.160 * *$ & (2.383) \\
\hline$P R O P$ & & & & & 0.077 & (1.300) \\
\hline \multicolumn{7}{|l|}{ TECH } \\
\hline$T D G$ & & & & & 0.083 & $(1.420)$ \\
\hline Y2004 & & & & & -0.073 & $(-1.459)$ \\
\hline Y2005 & & & & & -0.037 & $(-0.621)$ \\
\hline Y2006 & & & & & -0.004 & $(-0.084)$ \\
\hline$Y 2007$ & & & & & 0.044 & $(0.953)$ \\
\hline$Y 2008$ & & & & & 0.053 & $(0.823)$ \\
\hline $\operatorname{Adj} . R^{2}$ & 0.09 & & 0.13 & & 0.15 & \\
\hline$N$ & 102 & & 102 & & 102 & \\
\hline$F$-stat & 4.864 & & 5.212 & & 2.473 & \\
\hline \multicolumn{7}{|c|}{$\begin{array}{l}\text { Model: } E_{i t} / P_{i t-l}=\beta_{0}+\beta_{1} R E T_{i t}+\beta_{2} R D_{i t}+\beta_{3} R E T_{i t} * R D_{i t}+\text { Industry }+ \text { Year }+\varepsilon_{i t} \\
\text { The sample comprises } 102 \text { firm-year observations from firms in Bursa Malaysia during 2003- } \\
\text { 2008. The reported } t \text {-statistics are in parentheses and adjusted for heteroscedasticity (White, 1980). } \\
\text { Asterisks denote statistical significance at the } 1 \%(*), 5 \%(* *) \text {, or } 10 \%(* * *) \text { level, respectively. } \\
\text { Variable definitions: } E_{i t} \text { is the earnings per share for firm i in fiscal year } \mathrm{t} ; P_{i t-l} \text { is the price per } \\
\text { share at the beginning of the fiscal year; } R E T_{i t} \text { is the annual return of firm i in fiscal year } \mathrm{t} ; R D_{i t} \text { is } \\
\text { a dummy variable that equals } 1 \text { if } R E T_{i t} \text { is negative, and } 0 \text { otherwise; Industry are dummy variables } \\
\text { for Bursa Malaysia industry sectors; Year are dummy variables for fiscal years; and } \varepsilon_{i t} \text { is the error } \\
\text { term. }\end{array}$} \\
\hline
\end{tabular}

To examine whether reporting of earnings conservatism varies between different types of state-controlled firms, I estimated the basic pooled regression, the Fama and MacBeth (1973) annual regression, and fixed-effects regression. Table 6.26(a) reports regression estimates for firms under the control of the Federal Government of Malaysia, while Table 6.26(b) reports the results for firms under the control of State Governments. In Table 6.26(a), the coefficients for $R E T * R D$ in all 
estimation models are not significant, implying that firms under the control of the Federal Government do not report earnings conservatively. For Table 6.26(b), the coefficients for $R E T^{*} R D$ are not significant in the basic and Fama and MacBeth (1973) regressions but the coefficient is weakly significant in the fixed-effects regression. These results show that, in general, state-controlled firms do not report earnings conservatively.

The situation might result from the complex principal-agent relationship and poor monitoring mechanisms in state-controlled firms. As discussed in Section 6.5.2, the government has a higher tendency to intervene in poorly-performing statecontrolled firms, the managers of these firms are more likely to avoid such interference, that is by exploiting reporting discretion in order to portray an optimistic outlook (Bushman \& Piotroski, 2006). Furthermore, state-controlled firms were pressured by the government to upwardly tilt their reporting decisions (Bushman \& Piotroski, 2006).

\subsubsection{Additional Analysis}

This section extends the analysis of the relationship between ownership structure and earnings conservatism in two ways. First, this study examines whether there is a significant difference between the levels of earnings conservatism of family firms and widely-held firms. Second, this study examines whether strategic control by a family of the board of directors, that is by holding the positions of both CEO and chairman of the board, influences earnings conservatism. 


\subsubsection{Difference in Earnings Conservatism between Family Firms and Widely-Held Firms.}

This section further examines systematic differences between the level of earnings conservatism of family firms and widely-held firms. A new variable, named FAMILY, which takes value 1 for family firms and 0 for widely-held firms, was established. Other interaction variables, FAMILY*RET, FAMILY*RD and $F A M I L Y * R E T * R D$, were also introduced and included in the equation below.

$$
\begin{aligned}
E_{i t} / P_{i t-l}= & \beta_{0}+\beta_{1} R E T_{i t}+\beta_{2} R D_{i t}+\beta_{3} R E T_{i t} * R D_{i t}+\beta_{4} F A M I L Y_{i t} \\
& +\beta_{5} F_{A M I L Y_{i t} * R E T_{i t}+\beta_{6} F A M I L Y_{i t} * R D_{i t}} \\
& +\beta_{7} \text { FAMILY }_{i t} * R E T_{i t} * R D_{i t}+\varepsilon_{i t}
\end{aligned}
$$

where $E_{i t}$ is the earnings per share for firm $\mathrm{i}$ in fiscal year $\mathrm{t} ; P_{i t-1}$ is the price per share at the beginning of the fiscal year; $R E T_{i t}$ is the annual return of firm $\mathrm{i}$ in fiscal year $\mathrm{t}$; $R D_{i t}$ is a dummy variable that equals 1 if $R E T_{i t}$ is negative, and 0 otherwise; FAMILY is a dummy variable that takes value 1 if the observation is family firm, 0 if widely-held firms; and $\varepsilon_{i t}$ is the error term.

I estimated equation (6.2) using the basic pooled regression, Fama and MacBeth (1973) annual regression, and fixed-effects regression. The results are presented in Table 6.27. The regression estimates for all models show no significant difference between earnings conservatism for family firms and widely-held firms. The coefficients for $F A M I L Y * R E T * R D$ in all models are not significant $(\mathrm{p}>0.10)$, suggesting no evidence that family firms have higher or lower earnings conservatism compared to widely-held firms. The $F$-statistics are significant at the 
$1 \%$ level in all models, while adjusted- $R^{2}$ s are between $8 \%$ and $10 \%$, indicating the validity of the models.

Table 6.27

Earnings Conservatism: Family firms versus widely-held firms

\begin{tabular}{|c|c|c|c|c|c|c|}
\hline \multirow[b]{2}{*}{ Variable } & \multicolumn{2}{|c|}{ Pooled Regression } & \multicolumn{2}{|c|}{ Fama-MacBeth } & \multicolumn{2}{|c|}{ Fixed Effects } \\
\hline & Coeff & $t$-stat & Coeff & $t$-stat & Coeff & $t$-stat \\
\hline Intercept & $0.040^{* * *}$ & $(2.370)$ & $0.047 * * *$ & $(2.191)$ & -0.009 & $(-0.331)$ \\
\hline$R E T$ & 0.028 & $(0.932)$ & 0.026 & $(0.913)$ & $0.026 * * *$ & (1.916) \\
\hline$R D$ & -0.006 & $(-0.252)$ & 0.005 & $(0.289)$ & -0.018 & $(-0.705)$ \\
\hline$R E T * R D$ & $0.185^{*}$ & (3.102) & $0.342 * * *$ & $(2.469)$ & $0.259 *$ & (4.111) \\
\hline FAMILY & 0.019 & $(0.914)$ & $0.030 * * *$ & $(2.131)$ & 0.018 & $(1.005)$ \\
\hline$F A M I L Y^{*} R E T$ & $0.063 * * *$ & (1.906) & 0.049 & $(1.838)$ & $0.062 *$ & (3.804) \\
\hline$F A M I L Y * R D$ & 0.021 & $(0.647)$ & 0.003 & $(0.101)$ & 0.028 & $(0.859)$ \\
\hline$F A M I L Y^{*} R E T^{*} R D$ & 0.016 & $(0.197)$ & -0.029 & $(-0.256)$ & 0.028 & $(0.340)$ \\
\hline CONS & & & & & 0.018 & $(0.758)$ \\
\hline HOTEL & & & & & -0.032 & $(-0.524)$ \\
\hline$I P C$ & & & & & 0.078 & $(1.289)$ \\
\hline IPROD & & & & & $0.042^{* * *}$ & $(1.925)$ \\
\hline PLANT & & & & & 0.018 & $(0.613)$ \\
\hline PROP & & & & & 0.005 & $(0.198)$ \\
\hline TECH & & & & & 0.041 & (1.196) \\
\hline$T D G$ & & & & & 0.026 & (1.130) \\
\hline Y2004 & & & & & 0.014 & $(0.759)$ \\
\hline Y2005 & & & & & $0.071 *$ & $(3.791)$ \\
\hline Y2006 & & & & & -0.011 & $(-0.597)$ \\
\hline Y2007 & & & & & $0.048 *$ & $(2.655)$ \\
\hline Y2008 & & & & & $0.117 *$ & $(6.150)$ \\
\hline $\operatorname{Adj} . R^{2}$ & 0.08 & & 0.12 & & 0.10 & \\
\hline$N$ & 2892 & & 2892 & & 2892 & \\
\hline$F$-stat & 26.723 & & 39.807 & & 17.578 & \\
\hline
\end{tabular}

Model: $E_{i t} / P_{i t-l}=\beta_{0}+\beta_{l} R E T_{i t}+\beta_{2} R D_{i t}+\beta_{3} R E T_{i t} * R D_{i t}+\beta_{4} F A M I L Y_{i t}+\beta_{5} F A M I L Y_{i t} * R E T_{i t}$ $+\beta_{6} F A M I L Y_{i t} * R D_{i t}+\beta_{7} F A M I L Y_{i t} * R E T_{i t} * R D_{i t}+\varepsilon_{i t}$

The sample comprises 2,892 firm-year observations from firms in Bursa Malaysia during 20032008. The reported $t$-statistics are in parentheses and adjusted for heteroscedasticity (White, 1980). Asterisks denote statistical significance at the $1 \%(*), 5 \%(* *)$, or $10 \%(* * *)$ level, respectively. Variable definitions: $E_{i t}$ is the earnings per share for firm i in fiscal year $\mathrm{t} ; P_{i t-1}$ is the price per share at the beginning of the fiscal year; $R E T_{i t}$ is the annual return of firm i in fiscal year $\mathrm{t} ; R D_{i t}$ is a dummy variable that equals 1 if $R E T_{i t}$ is negative, and 0 otherwise; FAMILY is a dummy variable that takes value 1 if the observation is family firm, 0 if widely-held firms; Industry are dummy variables for Bursa Malaysia industry sectors; Year are dummy variables for fiscal years; and $\varepsilon_{i t}$ is the error term. 


\subsubsection{Strategic Control of Controlling Family and Earnings Conservatism}

Prior studies of the separation of the roles of CEO and chairman have focused on managerial compensation (Boyd, 1994), earnings restatement (Abbott, et al., 2004), fraudulent financial reporting (Beasley, Carcello, Hermanson, \& Lapides, 2000), and audit committees in the UK/US setting (Collier, 1993; Pincus, Rusbarsky, \& Wong, 1989; Turpin \& DeZoort, 1998), but no study has considered how CEO duality in family firms influences earnings conservatism.

Hence, I include in this study an examination of this issue. I posit that when a controlling shareholder has strong control over the management and the corporate board, these firms have lower agency costs and less incentive for opportunistic reporting; hence these firms report more conservative earnings than other family firms. I assume that a family firm is under the strong influence of the controlling family when the CEO is appointed from that family and he also acts as the chairman of the corporate board.

To conduct the test, firstly, I restricted the sample to family firms. Secondly, I created a dummy variable, DUALITY, that takes the value of 1 when a member of the controlling family holds both the positions of CEO and chairman of the board of directors, otherwise 0. Thirdly, I estimated equation (6.3), modified from the Basu (1997) asymmetric timeliness of earnings model, to test for significant differences in the earnings conservatism level between family firms with strong family influence and family firms with less or no influence of a controlling family. 


$$
\begin{aligned}
E_{i t} / P_{i t-1}=\quad & \beta_{0}+\beta_{1} R E T_{i t}+\beta_{2} R D_{i t}+\beta_{3} R E T_{i t} * R D_{i t}+\beta_{4} D U A L I T Y_{i t} \\
& +\beta_{5} \text { DUALITY }_{i t} * R E T_{i t}+\beta_{6} \text { DUALITY }_{i t} * R D_{i t} \\
& +\beta_{7} \text { DUALITY }_{i t} * R E T_{i t} * R D_{i t}+\varepsilon_{i t}
\end{aligned}
$$

where $E_{i t}$ is the earnings per share for firm $\mathrm{i}$ in fiscal year $\mathrm{t}$; $P_{i t-1}$ is the price per share at the beginning of the fiscal year; $R E T_{i t}$ is the annual return of firm $\mathrm{i}$ in fiscal year $\mathrm{t} ; R D_{i t}$ is a dummy variable that equals 1 if $R E T_{i t}$ is negative, and 0 otherwise; DUALITY is a dummy variable that takes value 1 if the family firm's CEO also acts as the chairman for the board of directors, and 0 otherwise; and $\varepsilon_{i t}$ is the error term.

I predict that the dual roles of CEO and chairman in a family firm would result in less incentive to manipulate earnings, hence leading to reporting of more conservative earnings. The argument is that the CEO's duality in family firms alleviates the agency cost, because the CEO's compensation is less likely to be influenced by earnings numbers. My prediction is that family firms in which the CEO also acts as the chairman of the board are more likely to report more conservative earnings than other family firms.

The estimation results based on the basic pooled regression, Fama and MacBeth (1973) annual regression, and fixed-effects regression controlling for industry and year effects are presented in Table 6.28. The results show higher earnings conservatism if a member of the controlling family acts as CEO and chairman of the board of directors. The coefficient for $D U A L I T Y^{*} R E T^{*} R D$ in the pooled regression is 0.434 and significant at the $5 \%$ level. Similar results are found when using Fama and MacBeth (1973) annual regression and fixed-effects regression, 
in which the coefficient for DUALITY $* R E T * R D$ is 0.376 and 0.387 , and significant at the $10 \%$ and $5 \%$ levels respectively.

Table 6.28

CEO duality in family firms and earnings conservatism

\begin{tabular}{|c|c|c|c|c|c|c|}
\hline \multirow{2}{*}{$\begin{array}{l}\text { Sample/ } \\
\text { Variable }\end{array}$} & \multicolumn{2}{|c|}{ Pooled regression } & \multicolumn{2}{|c|}{ Fama-MacBeth } & \multicolumn{2}{|c|}{ Fixed Effects } \\
\hline & Coeff & $t$-stat & Coeff & $t$-stat & Coeff & $t$-stat \\
\hline Intercept & $0.051^{*}$ & $(4.081)$ & $0.071^{* *}$ & $(3.632)$ & 0.024 & $(0.789)$ \\
\hline RET & $0.101 *$ & (6.998) & $0.087 *$ & (7.282) & $0.097 *$ & (9.700) \\
\hline$R D$ & 0.008 & $(0.367)$ & -0.000 & $(-0.002)$ & -0.001 & $(-0.067)$ \\
\hline$R E T * R D$ & $0.145^{*}$ & $(2.672)$ & $0.261^{*}$ & $(4.650)$ & $0.234^{*}$ & (3.976) \\
\hline DUALITY & $0.061 * * *$ & (1.857) & 0.041 & (1.008) & 0.046 & $(1.425)$ \\
\hline$D U A L I T Y^{*} R E T$ & -0.072 & $(-1.097)$ & -0.068 & $(-0.650)$ & $-0.068 * *$ & $(-2.484)$ \\
\hline$D U A L I T Y * R D$ & 0.059 & $(1.011)$ & 0.073 & $(1.458)$ & 0.058 & $(0.987)$ \\
\hline$D U A L I T Y * R E T * R D$ & $0.434 * *$ & $(2.240)$ & $0.376^{* * * *}$ & (2.419) & $0.387 * *$ & $(2.474)$ \\
\hline CONS & & & & & -0.004 & $(-0.122)$ \\
\hline HOTEL & & & & & $-0.143 * * *$ & $(-1.676)$ \\
\hline$I P C$ & & & & & 0.069 & $(0.816)$ \\
\hline IPROD & & & & & 0.024 & $(0.874)$ \\
\hline PLANT & & & & & -0.028 & $(-0.761)$ \\
\hline PROP & & & & & -0.034 & $(-1.137)$ \\
\hline TECH & & & & & 0.044 & $(0.953)$ \\
\hline$T D G$ & & & & & -0.022 & $(-0.741)$ \\
\hline$Y 2004$ & & & & & 0.021 & $(0.913)$ \\
\hline Y2005 & & & & & $0.091 *$ & (3.784) \\
\hline$Y 2006$ & & & & & 0.003 & $(0.122)$ \\
\hline Y2007 & & & & & $0.052 * *$ & $(2.228)$ \\
\hline Y2008 & & & & & $0.121^{*}$ & (4.959) \\
\hline $\operatorname{Adj} . R^{2}$ & 0.11 & & 0.16 & & 0.13 & \\
\hline$N$ & 1770 & & 1770 & & 1770 & \\
\hline$F$-stat & 21.994 & & 54.346 & & 14.119 & \\
\hline
\end{tabular}

Model: $E_{i t} / P_{i t-1}=\beta_{0}+\beta_{1} R E T_{i t}+\beta_{2} R D_{i t}+\beta_{3} R E T_{i t} * R D_{i t}+\beta_{4} D U A L I T Y_{i t}+\beta_{5} D U A L I T Y_{i t} * R E T_{i t}$ $+\beta_{6}$ DUALITY $_{i t} * R D_{i t}+\beta_{7} D U A L I T Y_{i t} * R E T_{i t} * R D_{i t}+\varepsilon_{i t}$

The sample comprises 2,892 firm-year observations from firms in Bursa Malaysia during 20032008. The reported $t$-statistics are in parentheses and adjusted for heteroscedasticity (White, 1980). Asterisks denote statistical significance at the $1 \%(*), 5 \%(* *)$, or $10 \%(* * *)$ level, respectively. Variable definitions: $E_{i t}$ is the earnings per share for firm i in fiscal year $\mathrm{t} ; P_{i t-1}$ is the price per share at the beginning of the fiscal year; $R E T_{i t}$ is the annual return of firm i in fiscal year $\mathrm{t} ; R D_{i t}$ is a dummy variable that equals 1 if $R E T_{i t}$ is negative, and 0 otherwise; DUALITY is a dummy variable that takes value 1 if a member of the controlling family holds both the positions of CEO and chairman of the board of directors, and 0 otherwise; Industry are dummy variables for Bursa Malaysia industry sectors; Year are dummy variables for fiscal years; and $\varepsilon_{i t}$ is the error term. 
These results imply that the strategic control of a family of the positions of CEO and chairman gives greater incentive to the managers to report more conservative earnings so as to minimise the perceived high 'agency conflict' between the controlling shareholder and other shareholders. Furthermore managers have lower incentives to opportunistically report earnings because the compensation of family members is not tied to earnings numbers.

To examine the robustness of these results, I estimated the following equation, modified from the time-series test of timeliness in loss recognition model, on the basic pooled model, Fama and MacBeth (1973) annual regression, and fixedeffects regression. The results are presented in Table 6.29.

$$
\begin{aligned}
\Delta N I_{i t}= & \alpha_{0}+\alpha_{1} \Delta N I_{i t-1}+\alpha_{2} D \Delta N I_{i t-1}+\alpha_{3} \Delta N I_{i t-1} * D \Delta N I_{i t-1}+\alpha_{4} D U A L I T Y_{i t-1} \\
& +\alpha_{5} \text { DUALITY }_{i t-1} * \Delta N I_{i t-1}+\alpha_{6} D U A L I T Y_{i t-1} * D \Delta N I_{i t-1} \\
& +\alpha_{7} D U \text { ULITY }_{i t-1} * \Delta N I_{i t-1} * D \Delta N I_{i t-1}+\varepsilon_{i t}
\end{aligned}
$$

where $\Delta N I_{i t}$ is the change in earnings for firm $\mathrm{i}$ from year t-1 to year $\mathrm{t}$, standardised by total assets at end of year t-1;DANI $I_{i t-1}$ is a dummy variable that equals 1 if $\triangle N I_{i t-1}$ if negative, and 0 otherwise; DUALITY is a dummy variable that takes value 1 if a member of the controlling family holds both the positions of CEO and chairman of the board of directors, and 0 otherwise; and $\varepsilon_{i t}$ is the error term. 
Table 6.29

Time-series test of timeliness in loss recognition: Strategic control of family firms

\begin{tabular}{|c|c|c|c|c|c|c|}
\hline \multirow[t]{2}{*}{ Sample } & \multicolumn{2}{|c|}{ Pooled regression } & \multicolumn{2}{|c|}{ Fama-MacBeth } & \multicolumn{2}{|c|}{ Fixed Effects } \\
\hline & Coeff & $t$-stat & Coeff & $t$-stat & Coeff & $t$-stat \\
\hline Intercept & $0.006^{* *}$ & $(2.074)$ & 0.006 & $(1.205)$ & -0.001 & $(-0.075)$ \\
\hline$\triangle N I_{i t-1}$ & $-0.150 *$ & $(-5.380)$ & -0.140 & $(-1.836)$ & $-0.149 *$ & $(-5.327)$ \\
\hline$D \triangle N I_{i t-1}$ & $-0.013^{*}$ & $(-2.636)$ & -0.013 & $(-1.868)$ & $-0.012 *$ & $(-2.585)$ \\
\hline$\triangle N I_{i t-1} * D \triangle N I_{i t-1}$ & $-0.551^{*}$ & $(-8.686)$ & $-0.556^{*}$ & $(-5.653)$ & $-0.558^{*}$ & $(-8.733)$ \\
\hline DUALITY $_{i t-1}$ & 0.009 & $(1.264)$ & 0.008 & $(1.173)$ & 0.009 & $(1.242)$ \\
\hline$D U A L I T Y_{i t-1} * \triangle N I_{i t-1}$ & -0.117 & $(-1.516)$ & -0.065 & $(-0.335)$ & -0.121 & $(-1.568)$ \\
\hline$D_{U A L I T Y}{ }_{i t-1} * D \wedge N I_{i t-1}$ & -0.019 & $(-1.550)$ & -0.012 & $(-1.062)$ & -0.020 & $(-1.583)$ \\
\hline$D_{U A L I T Y}{ }_{i t-1} * \Delta N I_{i t-1} * D \triangle N I_{i t-1}$ & $-0.297 * * *$ & $(-1.899)$ & -0.072 & $(-0.155)$ & $-0.301 * * *$ & $(-1.926)$ \\
\hline CONS & & & & & -0.002 & $(-0.302)$ \\
\hline HOTEL & & & & & -0.002 & $(-0.074)$ \\
\hline$I P C$ & & & & & -0.004 & $(-0.156)$ \\
\hline IPROD & & & & & 0.002 & $(0.276)$ \\
\hline PLANT & & & & & $0.025^{*}$ & $(2.606)$ \\
\hline$P R O P$ & & & & & -0.001 & $(-0.141)$ \\
\hline TECH & & & & & -0.000 & $(-0.026)$ \\
\hline$T D G$ & & & & & 0.005 & $(0.626)$ \\
\hline$Y 2004$ & & & & & 0.006 & (0.997) \\
\hline Y2005 & & & & & 0.001 & $(0.212)$ \\
\hline Y2006 & & & & & 0.004 & $(0.614)$ \\
\hline$Y 2007$ & & & & & $0.017 *$ & $(2.641)$ \\
\hline$Y 2008$ & & & & & -0.004 & $(-0.616)$ \\
\hline $\operatorname{Adj} . R^{2}$ & 0.15 & & 0.21 & & 0.15 & \\
\hline$N$ & 1762 & & 1762 & & 1762 & \\
\hline$F$-stat & 44.935 & & 23.881 & & 17.130 & \\
\hline
\end{tabular}

Model: $\Delta N I_{i t}=\alpha_{0}+\alpha_{1} \Delta N I_{i t-1}+\alpha_{2} D \Delta N I_{i t-1}+\alpha_{3} \Delta N I_{i t-1} * D \wedge N I_{i t-1}+\alpha_{4} D U A L I T Y_{i t-1}$

$$
\begin{aligned}
& +\quad a_{5} D U A L I T Y_{i t-1} * \triangle N I_{i t-1}+a_{6} D U A L I T Y_{i t-1} * D \triangle N I_{i t-1}+a_{7} D U A L I T Y_{i t-1} * \Delta N I_{i t-} \\
& { }_{1} * D \triangle N I_{i t-1}+\text { industry }+ \text { year }+\varepsilon_{i t}
\end{aligned}
$$

The sample comprises 2,876 firm-year observations from firms in Bursa Malaysia during 20032008. The reported t-statistics are in parentheses and adjusted for heteroscedasticity (White, 1980). Asterisks denote statistical significance at the $1 \%(*), 5 \%(* *)$, or $10 \%(* * *)$ level, respectively. Variable definitions: $\Delta N I_{i t}$ is the change in earnings for firm i from year $\mathrm{t}-1$ to year $\mathrm{t}$, standardised by total assets at end of year t-1;D$D N I_{i t-1}$ is a dummy variable that equals 1 if $\Delta N I_{i t-1}$ if negative, and 0 otherwise; DUALITY is a dummy variable that takes value 1 if a member of the controlling family holds both the positions of CEO and chairman of the board of directors, and 0 otherwise; Industry are dummy variables for Bursa Malaysia industry sectors; Year are dummy variables for fiscal years; and $\varepsilon_{i t}$ is the error term.

Given that the prediction is that a family firm in which the CEO also acts as the chairman of the board will have substantially different financial reporting, I am interested in the incremental coefficient $\alpha_{7}$. Consistent with the earlier analysis, 
the results in Table 6.29 show weak evidence that the strategic control of a family on the positions of CEO and chairman is associated with higher earnings reversal when incorporating transitory losses in earnings than other family firms, since the coefficients for $D U A L I T Y^{*} \Delta N I_{i t-1} * D \wedge N I_{i t-1}\left(\alpha_{7}\right)$ are negatively significant at the $10 \%$ level in the pooled regression model and estimation controlling for industry and year effects, coefficients of -0.297 and -0.301 , respectively. These results show evidence that holding the dual role of CEO and chairman of the board alleviates the agency costs in family firms, and reduces their incentives to report earnings aggressively. However, the coefficient for DUALITY* $\triangle N I_{i t-1} * D \wedge N I_{i t-1}$ is not significant when estimated using Fama and MacBeth (1973) annual regression. In general, the results show that earnings conservatism is more pervasive in firms in which the CEO also holds the role of chairman of the board.

\subsubsection{Discussion of the Results}

The third objective of this study was to examine whether ownership structure has significant influence on earnings conservatism. Given that family firms and statecontrolled firms are dominant in the Malaysian economy, this provides opportunities for examining how earnings conservatism levels vary according to ownership structure.

Employing the Basu (1997) asymmetric timeliness of earnings model, I find that earnings reflect bad news more quickly than good news in family firms and widely-held firms, indicating evidence of earnings conservatism. With regard to state-controlled firms, the results show that good news is recognised in a timely way but recognition of bad news is delayed, implying evidence of aggressive 
accounting. Various sensitivity tests were conducted, including Fama and Macbeth estimation, estimation controlling for industry and year effects, alternative definitions of family firms, classification of state-controlled firms into firms under the control of Federal and State governments. In all the tests, I find robust evidence of earnings conservatism in family firms and widely-held firms, but not in state-controlled firms.

These results suggest that ownership structure has a significant influence on earnings conservatism. The different levels of agency costs and of information asymmetry in each type of firm create varying incentives and demands regarding conservative earnings reporting. In family firms, the results provide support for 'alignment effects' theory, in which family firms exert greater monitoring and which provides higher incentives to report earnings conservatively. This is consistent with the evidence provided by Wang (2006), where family firms in the United States have higher earnings quality, in particular lower abnormal accruals, greater earnings informativeness, and less persistence of transitory loss components in earnings.

For state-controlled firms, the result is consistent with Bushman and Piotroski (2006), who find firms in common-law countries that face high state involvement in the economy tend to slow the recognition of bad news and speed the recognition of good news. As such, a high tendency to government intervention in poorly-performing state-controlled firms motivates managers to avoid such interference by reporting aggressive earnings (Bushman \& Piotroski, 2006). On the other hand, Bushman and Piotroski (2006) argued that state-controlled firms 
were pressured by the government to report higher earnings.

I further examined systematic differences in the level of earnings conservatism between family firms and widely-held firms. The results from the pooled regression, Fama and MacBeth (1973) annual regression, and fixed effect regression show no significant difference of earnings conservatism between family firms and widely-held firms. This result shows no evidence that widelyheld firms are different from family firms in respect of earnings conservatism.

I also conducted additional tests of whether strategic control by a controlling family is associated with higher earnings conservatism. The analysis shows that when a member of the controlling family acts as both CEO and chairman of the board of directors, the family firm reports earnings more conservatively than other family firms. This implies that holding the dual role of CEO and chairman of the board alleviates the agency costs in family firms and reduces incentives to report earnings aggressively. Another possible explanation is that these family firms employ earnings conservatism as a strategy to minimise the perceived high agency conflicts between the controlling shareholder and other shareholders.

\subsection{Corporate Governance and Earnings Conservatism}

\subsubsection{Introduction}

The final objective of this study is to examine the relationship between corporate governance and earnings conservatism. The following section, Section 6.6.2, presents and discusses the main empirical results, while Section 6.6.3 reports the 
sensitivity analyses. Discussions on the overall results are provided in Section 6.6.4.

\subsubsection{Corporate Governance Mechanism and Earnings Conservatism}

This section reports the regression estimates for equation (5.3a) and (5.3b), which tests the relationship between earnings conservatism and the corporate governance index, developed from 11 corporate governance variables.

Table 6.30

Corporate governance and earnings conservatism

\begin{tabular}{|c|c|c|c|c|c|}
\hline \multicolumn{4}{|c|}{ CGINDEX } & \multicolumn{2}{|c|}{ DUMCG } \\
\hline Variable & Coeff & $t$-stat & Variable & Coeff & $t$-stat \\
\hline Intercept & 0.015 & $(0.616)$ & Intercept & $0.034 * *$ & (2.209) \\
\hline$R E T$ & $0.083^{*}$ & (2.779) & $R E T$ & $0.087 *$ & (4.280) \\
\hline$R D$ & $0.081 * * *$ & (1.840) & $R D$ & 0.032 & (1.161) \\
\hline$R E T^{*} R D$ & $0.287^{* *}$ & $(2.550)$ & $R E T^{*} R D$ & $0.210^{*}$ & $(2.949)$ \\
\hline CGINDEX & 0.082 & (1.636) & $D U M C G$ & 0.029 & (1.374) \\
\hline CGINDEX*RET & -0.026 & $(-0.467)$ & $D U M C G^{*} R E T$ & -0.016 & $(-0.519)$ \\
\hline$C G I N D E X * R D$ & $-0.159 * * *$ & $(-1.813)$ & $D U M C G^{*} R D$ & $-0.071 * * *$ & $(-1.870)$ \\
\hline$C G I N D E X * R E T * R D$ & -0.214 & $(-0.976)$ & $D U M C G * R E T * R D$ & -0.124 & $(-1.349)$ \\
\hline $\operatorname{Adj} . R^{2}$ & 0.08 & & $\operatorname{Adj} . R^{2}$ & 0.08 & \\
\hline$N$ & 3126 & & $N$ & 2084 & \\
\hline$F$-stat & 26.770 & & $F$-stat & 21.873 & \\
\hline
\end{tabular}

The sample comprises 3,126 firm-year observations from firms in Bursa Malaysia during 20032008. The reported $t$-statistics are in parentheses and adjusted for heteroscedasticity (White, 1980). Asterisks denote statistical significance at the $1 \%(*), 5 \%(* *)$, or $10 \%(* * *)$ level, respectively. Variable definitions: $E_{i t}$ is the earnings per share for firm i in fiscal year $\mathrm{t} ; P_{i t-1}$ is the price per share at the beginning of the fiscal year; $R E T_{i t}$ is the annual return of firm i in fiscal year $\mathrm{t} ; R D_{i t}$ is a dummy variable that equals 1 if $R E T_{i t}$ is negative, and 0 otherwise; CGINDEX is an unweighted aggregate of 11 corporate governance variables; $D U M C G$ is a dummy variable that takes value 1 if CGINDEX is in the top third of the pooled sample, and 0 if CGINDEX is in the bottom third; Industry are dummy variables for Bursa Malaysia industry sectors; Year are dummy variables for fiscal years; and $\varepsilon_{i t}$ is the error term.

I employed two measures for corporate governance. First, I used CGINDEX, 
which is based on an unweighted corporate governance score from 11 corporate governance variables. Second, I used a $D U M C G$, which is a dummy variable that takes value 1 if CGINDEX is in the top third of the pooled sample, and 0 if CGINDEX is in the bottom third. The regression estimates are reported in Table 6.30 .

The results show that the coefficients for $R E T^{*} R D$ are positively significant in both estimation models, suggesting evidence of earnings conservatism. However, the coefficients for CGINDEX*RET*RD and $D U M C G^{*} R E T^{*} R D$ are not significant, suggesting no link from corporate governance to earnings conservatism.

\subsubsection{Sensitivity Analysis}

To examine the robustness of the main results discussed in section 6.6.2, I conducted several sensitivity analyses which included (i) the use of an alternative measure for CGINDEX; (ii) individual measures for corporate governance variables; and (iii) time-series test of timeliness in loss recognition.

\subsubsection{Alternative Measure for CGINDEX}

I re-calculated CGINDEX using nine internal corporate governance variables such as board size (BODSIZE), non-executive directors (NONEXEC), board independence (BODIND), independent chairman (INDCHRM), board meetings (BODMEET), size of audit committee (ACSIZE), audit committee independence (ACINDP), number of audit committee meetings (ACMEET), and financial 
expertise of audit committee (ACEXPERT). I then re-estimated equation (5.3a) using basic pooled regression, Fama and MacBeth (1973) annual regression, and fixed-effects regression to test the relationship between earnings conservatism and corporate governance. The results are reported in Table 6.31 .

Table 6.31

Corporate governance and earnings conservatism: An alternative measurement

\begin{tabular}{|c|c|c|c|c|c|c|}
\hline \multirow[b]{2}{*}{ Variable } & \multicolumn{2}{|c|}{ Basic } & \multicolumn{2}{|c|}{ Fama-MacBeth } & \multicolumn{2}{|c|}{ Fixed Effects } \\
\hline & Coeff & $t$-stat & Coeff & $t$-stat & Coeff & $t$-stat \\
\hline Intercept & $0.041^{* * * *}$ & $(1.726)$ & 0.041 & $(1.700)$ & -0.003 & $(-0.084)$ \\
\hline$R E T$ & $0.075^{* *}$ & (2.477) & 0.065 & (1.592) & $0.069^{* *}$ & $(2.263)$ \\
\hline$R D$ & $0.073 * * *$ & (1.738) & 0.070 & (1.168) & $0.071 * * *$ & (1.688) \\
\hline$R E T * R D$ & $0.281 *$ & $(2.580)$ & 0.186 & (1.234) & $0.354^{*}$ & $(3.259)$ \\
\hline CGINDEX & 0.025 & $(0.536)$ & 0.056 & $(0.858)$ & 0.004 & $(0.079)$ \\
\hline$C G I N D E X^{*} R E T$ & -0.009 & $(-0.158)$ & -0.025 & $(-0.316)$ & -0.004 & $(-0.063)$ \\
\hline$C G I N D E X * R D$ & -0.142 & $(-1.610)$ & -0.135 & $(-1.069)$ & $-0.155 * * *$ & $(-1.750)$ \\
\hline$C G I N D E X^{*} R E T * R D$ & -0.207 & $(-0.926)$ & 0.306 & $(0.859)$ & -0.195 & $(-0.869)$ \\
\hline CONS & & & & & 0.023 & $(0.909)$ \\
\hline HOTEL & & & & & -0.040 & $(-0.743)$ \\
\hline$I P C$ & & & & & 0.020 & $(0.584)$ \\
\hline IPROD & & & & & $0.042 * * *$ & (1.734) \\
\hline PLANT & & & & & 0.032 & $(1.049)$ \\
\hline$P R O P$ & & & & & 0.015 & $(0.549)$ \\
\hline TECH & & & & & 0.038 & (1.039) \\
\hline$T D G$ & & & & & 0.032 & (1.269) \\
\hline Y2004 & & & & & 0.013 & $(0.779)$ \\
\hline Y2005 & & & & & $0.068^{*}$ & (3.994) \\
\hline Y2006 & & & & & -0.009 & $(-0.483)$ \\
\hline Y2007 & & & & & $0.050^{*}$ & $(3.116)$ \\
\hline Y2008 & & & & & $0.119 *$ & $(6.613)$ \\
\hline $\operatorname{Adj} . R^{2}$ & 0.08 & & 0.12 & & 0.10 & \\
\hline$N$ & 3126 & & 3126 & & 3126 & \\
\hline$F$-stat & 26.084 & & 59.581 & & 11.511 & \\
\hline
\end{tabular}

Model: $E_{i l} / P_{i t-l}=\beta_{0}+\beta_{1} R E T_{i t}+\beta_{2} R D_{i t}+\beta_{3} R E T_{i t} * R D_{i t}+\beta_{4} C G I N D E X_{i t}+\beta_{5} C_{G I N D E X_{i t}} * R E T_{i t}+$ $\beta_{6} C_{\text {GINDEX }} * R D_{i t}+\beta_{7}$ CGINDEX $_{i t} * R E T_{i t} * R D_{i t}+\varepsilon_{i t}$

The sample comprises 3,126 firm-year observations from firms in Bursa Malaysia during 20032008. The reported $t$-statistics are in parentheses and adjusted for heteroscedasticity (White, 1980). Asterisks denote statistical significance at the $1 \%(*), 5 \%(* *)$, or $10 \%(* * *)$ level, respectively. Variable definitions: $E_{i t}$ is the earnings per share for firm i in fiscal year $\mathrm{t} ; P_{i t-1}$ is the price per share at the beginning of the fiscal year; $R E T_{i t}$ is the annual return of firm i in fiscal year $\mathrm{t} ; R D_{i t}$ is a dummy variable that equals 1 if $R E T_{i t}$ is negative, and 0 otherwise; CGINDEX is an unweighted aggregate of nine corporate governance variables; Industry are dummy variables for Bursa Malaysia industry sectors; Year are dummy variables for fiscal years; and $\varepsilon_{i t}$ is the error term. 
Table 6.31 shows qualitatively similar results as results reported in the previous section. As in the previous results of the study, the coefficients for $R E T^{*} R D$ are positively significant in both estimation models, suggesting evidence of earnings conservatism. However, the coefficients for CGINDEX*RET*RD are not significant $(p>0.10)$, suggesting that there is no evidence link corporate governance and earnings conservatism. With respect to the validity of the models, all $F$-statistics are significant at the $1 \%$ level, while the values for adjusted- $R^{2}$ are $8 \%$, which is similar to the earlier findings.

\subsubsection{Individual Measures for Corporate Governance}

In this section, I report the analyses on the relationship between earnings conservatism and individual corporate governance mechanisms by comparing the levels of earnings conservatism between subsamples of firms with good and bad governance based on 11 proxies. I modified equation (5.3a) by replacing CGINDEX with individual corporate governance variables such as BODSIZE, NONEXEC, BODIND, INDCHRM, BODMEET, ACSIZE, ACIND, ACMEET, $A C E X P E R T, B I G 4$, and SPECIALIST. These variables are dummy variables which take value 1 for good governance firms and 0 for poor governance firms. Explanations about the dummy variables were provided in Section 5.6. I then reestimated the modified equation (5.2) to examine the relationship between individual corporate governance mechanisms and earnings conservatism. The results are presented in Table 6.32 . 


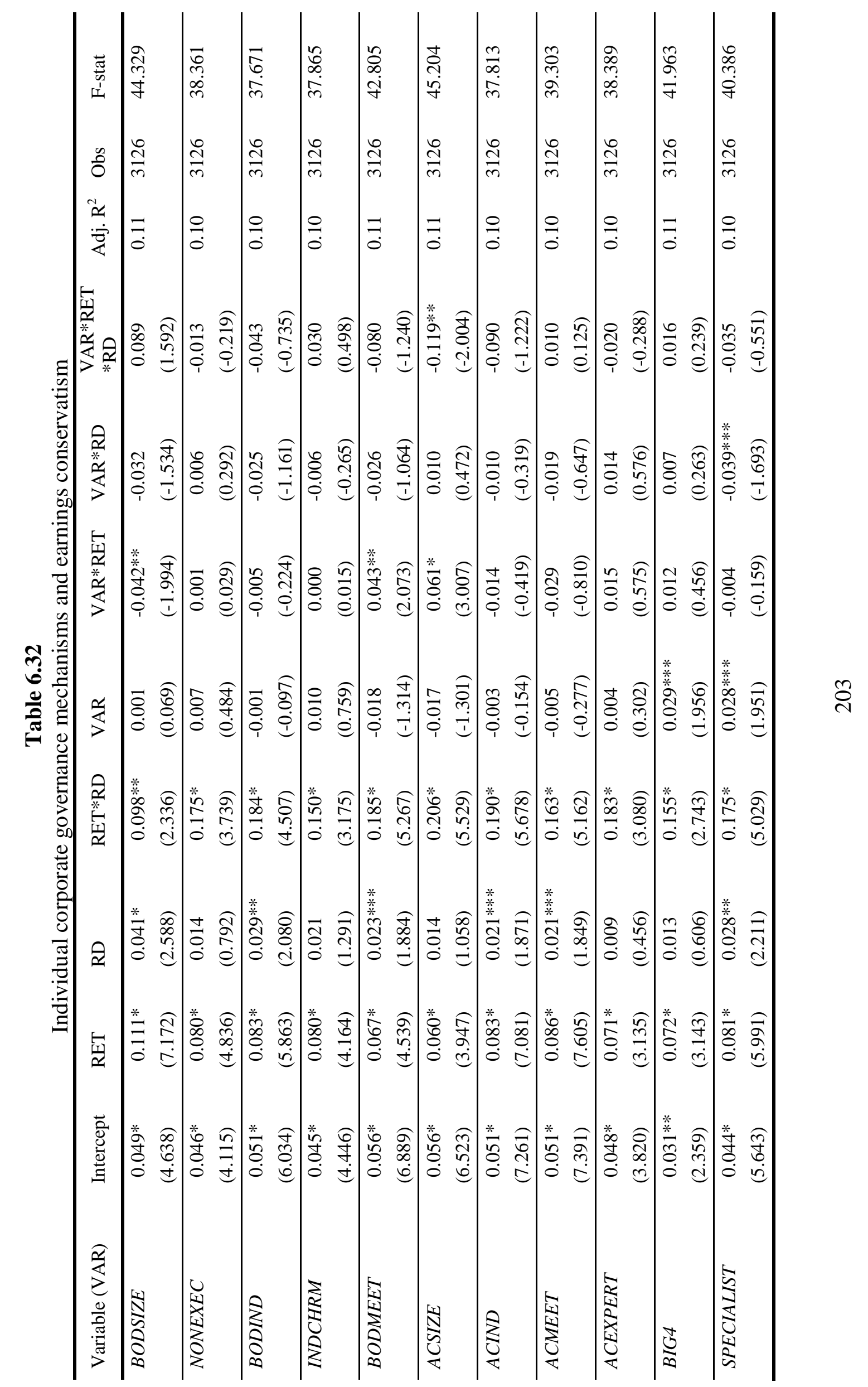




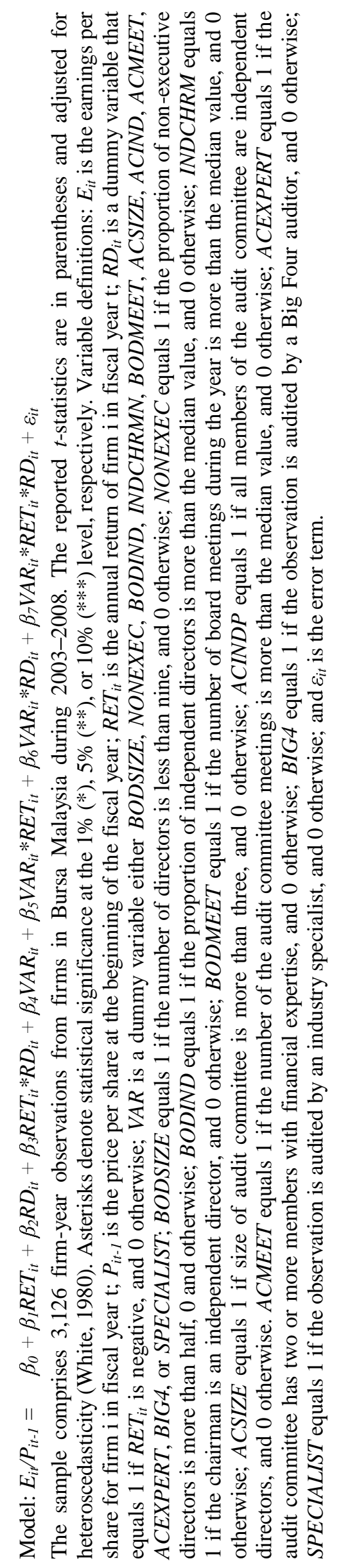


Overall results reported in Table 6.32 show that the only case of significant difference between earnings conservatism for firms with good and poor corporate governance is related to audit committee size. The coefficient for $A C S I Z E * R E T * R D$ is negative (-1.161) and significant at the $5 \%$ level, suggesting evidence of lower earnings conservatism in firms with a bigger audit committee.

This result is contrary to prior studies, for example Ahmed and Duellman (2007) and García Lara and Mora (2004), who find evidence that corporate governance measures have significant association with earnings conservatism. For instance, the proportion of outside directors is found to be associated with earnings conservatism in the United Kingdom (Beekes, et al., 2004) and in the United States (Ahmed \& Duellman, 2007), where the percentage of outside directors is positively related to conservatism. Furthermore, García Lara et al. (2007) find that firms where the CEO has a low influence over the functioning of the board of directors show a greater degree of accounting conservatism. However, these studies relate to developed markets with fewer family firms. My results for family firms which show a high levels of conservatism regardless of governance quality, suggests that perhaps corporate governance mechanisms that are relevant for firms in developed countries are not relevant for family firms in developing countries.

\subsubsection{Time-Series Test of Timeliness in Loss Recognition}

I modified equation (1.2) in order to investigate further the relationship between corporate governance and earnings conservatism. This modification enables an examination of the incremental reversal of earnings changes from previous year changes of earnings as a result of corporate governance. The modified model is as 
follows:

$$
\begin{aligned}
& \Delta N I_{i t}=\alpha_{0}+\alpha_{1} \Delta N I_{i t-1}+\alpha_{2} D \wedge N I_{i t-1}+\alpha_{3} \wedge N I_{i t-1} * D \wedge N I_{i t-1}+\alpha_{4} C G I N D E X_{i t-1} \\
& +\alpha_{5} \operatorname{CGINDEX}_{i t-1} * \wedge N I_{i t-1}+\alpha_{6} C G I N D E X_{i t-1} * D \wedge N I_{i t-1} \\
& \alpha_{7} C_{\text {CGINDEX }}{ }_{i t-1} * \Delta N I_{i t-1} * D \Delta N I_{i t-1}+\varepsilon_{i t}
\end{aligned}
$$

where $\Delta N I_{i t}$ is the change in earnings for firm $\mathrm{i}$ from year $\mathrm{t}-1$ to year $\mathrm{t}$,

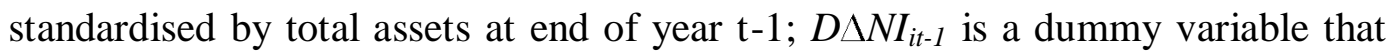
equals 1 if $\triangle N I_{i t-1}$ if negative, and 0 otherwise; CGINDEX is an unweighted corporate governance score developed from 11 corporate governance variables; and $\varepsilon_{i t}$ is the error term.

I estimated the above equation, which tests for significant differences between earnings conservatism for firms with good and poor corporate governance using the unweighted corporate governance index (CGINDEX) developed from 11 corporate governance variables. The regression estimates are summarised in Table 6.33 .

Consistent with the earlier analysis, the results in Table 6.33 show that firms with good corporate governance are not likely to have higher earnings reversal when incorporating transitory losses in income, compared with firms with poor corporate governance, since the coefficients for CGINDEX*ANI $I_{i t-1} * D \wedge N I_{i t-1}\left(\alpha_{6}\right)$ are not statistically significant $(p>0.10)$ for all estimation models (coefficients of $0.554,0.265$, and 0.557$)$. 
Table 6.33

Corporate governance score and the time-series test of timeliness in loss recognition: Pooled regression, Fama and MacBeth (1973) annual regression, estimation controlling for industry and year effects

\begin{tabular}{|c|c|c|c|c|c|c|}
\hline \multirow[t]{2}{*}{ Sample } & \multicolumn{2}{|c|}{ Pooled regression } & \multicolumn{2}{|c|}{ Fama-MacBeth } & \multicolumn{2}{|c|}{ Fixed Effects } \\
\hline & Coeff & $t$-stat & Coeff & $t$-stat & Coeff & $t$-stat \\
\hline Intercept & 0.010 & $(1.626)$ & 0.012 & $(1.609)$ & 0.007 & $(0.754)$ \\
\hline$\triangle N I_{i t-1}$ & -0.209 & $(-1.311)$ & -0.250 & $(-1.274)$ & -0.211 & $(-1.320)$ \\
\hline$D \wedge N I_{i t-I}$ & $-0.025 * *$ & $(-2.218)$ & -0.024 & $(-1.664)$ & $-0.024 * *$ & $(-2.209)$ \\
\hline$\triangle N I_{i t-1} * D \wedge N I_{i t-1}$ & $-0.959^{*}$ & $(-3.096)$ & $-0.874^{*}$ & $(-5.290)$ & $-0.964 *$ & $(-3.108)$ \\
\hline CGINDEX $X_{i t-1}$ & -0.008 & $(-0.656)$ & -0.013 & $(-0.927)$ & -0.011 & $(-0.876)$ \\
\hline$C G I N D E X_{i t-1} * \wedge N I_{i t-1}$ & 0.204 & $(0.676)$ & 0.326 & $(0.963)$ & 0.212 & $(0.699)$ \\
\hline$C G I N D E X_{i t-1} * D \triangle N I_{i t-1}$ & 0.017 & $(0.752)$ & 0.013 & $(0.505)$ & 0.017 & $(0.791)$ \\
\hline$C G I N D E X_{i t-1} * \Delta N I_{i t-1} * D \Delta N I_{i t-1}$ & 0.554 & $(0.924)$ & 0.265 & $(1.445)$ & 0.557 & $(0.930)$ \\
\hline CONS & & & & & -0.002 & $(-0.262)$ \\
\hline HOTEL & & & & & 0.000 & $(0.022)$ \\
\hline$I P C$ & & & & & -0.005 & $(-0.357)$ \\
\hline IPROD & & & & & 0.001 & $(0.147)$ \\
\hline PLANT & & & & & $0.015 * * *$ & (1.819) \\
\hline PROP & & & & & -0.002 & $(-0.234)$ \\
\hline TECH & & & & & -0.006 & $(-0.435)$ \\
\hline$T D G$ & & & & & 0.000 & $(0.016)$ \\
\hline Y2004 & & & & & 0.002 & $(0.407)$ \\
\hline Y2005 & & & & & 0.000 & (0.034) \\
\hline Y2006 & & & & & 0.003 & $(0.502)$ \\
\hline Y2007 & & & & & $0.017^{*}$ & $(3.071)$ \\
\hline Y2008 & & & & & -0.001 & $(-0.096)$ \\
\hline Adj. $R^{2}$ & 0.14 & & 0.18 & & 0.14 & \\
\hline$N$ & 3105 & & 3105 & & 3105 & \\
\hline$F$-stat & 15.040 & & 38.864 & & 7.186 & \\
\hline
\end{tabular}

Model: $\Delta N I_{i t}=\alpha_{0}+\alpha_{1} \Delta N I_{i t-1}+\alpha_{2} D \Delta N I_{i t-1}+\alpha_{3} \Delta N I_{i t-1} * D \Delta N I_{i t-1}+\alpha_{4} C G I N D E X_{i t-1}$ $+a_{5}$ CGINDEX $_{i t-1} * \triangle N I_{i t-1}+a_{6} C_{\text {CGINDEX }}{ }_{i t-1} * D \triangle N I_{i t-1}$

$+a_{7} C G I N D E X_{i t-1} * \Delta N I_{i t-1} * D \triangle N I_{i t-1}+$ industry + year $+\varepsilon_{i t}$

The sample comprises 3,105 firm-year observations from firms in Bursa Malaysia during 20032008. The reported t-statistics are in parentheses and adjusted for heteroscedasticity (White, 1980). Asterisks denote statistical significance at the $1 \%(*), 5 \%(* *)$, or $10 \%(* * *)$ level, respectively. Variable definitions: $\triangle N I_{i t}$ is the change in earnings for firm i from year t- 1 to year $t$, standardised by total assets at end of year $\mathrm{t}-1 ; D \Lambda N I_{i-1}$ is a dummy variable that equals 1 if $\Delta N I_{i t-1}$ if negative, and 0 otherwise; CGINDEX is the unweighted corporate governance score developed from 11 corporate governance variables; Industry are dummy variables for Bursa Malaysia industry sectors; Year are dummy variables for fiscal years; and $\varepsilon_{i t}$ is the error term. 


\subsubsection{Discussion of the Results}

The final objective of this study is to examine the relationship between corporate governance and earnings conservatism. Using 11 corporate governance variables, I estimated the modified Basu (1997) reverse regression model, the results of which show no significant evidence linking corporate governance and earnings conservatism. For robustness tests, I employed three procedures: (i) alternative measure for CGINDEX and DUMCG; (ii) individual measures for corporate governance; and (iii) estimation based on time-series test of timeliness in loss recognition. All these tests failed to find a significant relationship between corporate governance and earnings conservatism.

\subsection{Summary of Results}

This chapter presents the findings of this study based on various analyses conducted in accordance with the research objectives and hypotheses. Four main findings can be concluded from this study.

Firstly, this study finds robust evidence that earnings conservatism is a strong feature of Malaysian financial reporting following the institutional reforms of corporate governance and financial reporting. Specifically, earnings reflect bad news in a more timely manner than they reflect good news. The plausible explanation from this finding is that firms have greater incentives and demands to report high-quality earnings, in particular by more timely recognition of bad news compared to good news, when the institutional structure is strong. In contrast, the weak institutional structures in the period before the 1997 economic crisis resulted 
in less incentive for preparers of financial reports to report earnings conservatively (Ball, et al., 2003). The results of this study provide support for arguments made by Bushman and Piotroski (2006) and Ball et al. (2003) that institutional structures have significant influence on earnings conservatism.

Secondly, this study finds no significant difference between the degree of earnings conservatism in the periods before and after the adoption of IFRS. The main analysis and various sensitivity tests fail to find any evidence showing significantly higher or lower earnings conservatism in the post-IFRS period relative to the pre-IFRS period. The plausible explanation is that managers, preparers of financial reports and auditors have greater incentives to report earnings conservatively, though the accounting standards warranted unbiased information. This provides support to the role of earnings conservatism in improving debt-contracting, minimizing litigation risk, and enhancing greater monitoring. This result is consistent with LaFond and Watts's (2008) prediction, in which any initiatives to reduce earnings conservatism would increase the agency cost and the litigation risk, hence forcing market-based mechanisms to require firms to report more conservative earnings.

Thirdly, this study finds that bad news is recognised in a more timely fashion than good news in family firms and widely-held firms, showing evidence of earnings conservatism. In state-controlled firms, the results show that good news is recognised in a timely way but recognition of bad news is delayed, implying evidence of aggressive accounting. In all tests, I find robust evidence of earnings conservatism in family firms and widely-held firms, but not in state-controlled 
firms. These results suggest that ownership structure has a significant influence on earnings conservatism. The levels of agency costs and information asymmetry are varied between ownership structures, thereby creating varying incentives and demands towards conservative earnings reporting. In family firms, the results provide support for 'alignment effects' theory, in which family firms exert greater monitoring and provide higher incentives to report earnings conservatively. In addition, the results show evidence that one person holding the dual role of CEO and chairman of the board alleviates agency costs in family firms, and reduces incentives to report earnings aggressively. Another possible explanation is family firms report more conservative earnings in order to minimise the perceived high agency conflict between the controlling shareholder and other shareholders.

Finally, this study fails to find any significant relationship between corporate governance and earnings conservatism. None of the tests show a significant relationship between the corporate governance index and earnings conservatism. 


\section{CHAPTER SEVEN CONCLUSIONS}

\subsection{Introduction}

This chapter provides a summary of the study. Section 7.2 discusses the findings and contributions of this study while Section 7.3 highlights several limitations of this study.

\subsection{Summary}

The purpose of this study was to investigate the issues relating to earnings conservatism in an emerging market. Motivated by the work of Basu (1997), Ball et al. (2003), and Bushman and Piotroski (2006), this study aims to provide empirical evidence on earnings conservatism in Malaysia. Using a sample of 3,126 firm-year observations, this study examines four main hypotheses.

First, this study examines earnings conservatism in Malaysian financial reporting following the corporate governance and financial reporting reforms. Contrary to Ball et al. (2003), who find no evidence of earnings conservatism in a Malaysian sample from 1984 to 1996, this study finds earnings conservatism is a strong feature of Malaysian financial reporting following the corporate governance and financial reporting reforms. The study finds that earnings reflect bad news received contemporaneously, but delay in the recognition of good news. These results imply that the reforms in corporate governance and financial reporting give strong incentives for Malaysian firms to practise conservative earnings reporting. 
Second, this study investigates the effect of IFRS adoption on the level of earnings conservatism. The results show no systematic difference in the level of earnings conservatism for the short period of one to two years before and after adoption, suggesting that the change from MASB standards to IFRS standards has had no effect on the level of earnings conservatism in Malaysian financial reporting. This finding supports the argument of Ball et al. (2003) that accounting standards have had limited impact on earnings conservatism in financial reporting. In addition, it is apparent that the attempt to eliminate conservatism from financial statements failed because it increases rather than reduces information asymmetry. According to LaFond and Watts (2008), conservatism reduces managers' incentives and ability to manipulate earnings and thus reduce information asymmetry and the deadweight losses that information asymmetry generates. In short, conservatism is an ineradicable and an indispensable quality of financial reports, even though it is criticised by the standard setters.

Third, this study extends prior studies by examining how the levels of earnings conservatism varies across different types of ownership structures, namely family firms, state-controlled firms, and widely-held firms. Since different types of ownership are subject to different level and types of agency conflict, the incentives to report earnings conservatively may also vary. For state-controlled firms, this study fails to find evidence of earnings conservatism. The results indicate aggressive accounting. For family firms and widely-held firms, bad news is recognised in earnings on a more timely basis than is good news. The test for difference between family firms and widely-held firms reveals no statistical difference in the levels of earnings conservatism of the two groups. 
Indirectly, this study provides evidence in support of the convergence of interest hypothesis, in so far it finds no evidence that family firms produce less conservative earnings compared to widely-held firms. This study further tests the effect of the strategic control of the controlling families on earnings conservatism. The results show firms that are strategically controlled by a family, that is, where a member of the controlling family acts as CEO and chairman of the corporate board, report significantly higher earnings conservatism than other family firms. This result implies that managers of firms that are strategically controlled by a family are more likely to have less incentive for opportunistic reporting and are more likely to have greater demand for conservative reporting. Overall, the results show that ownership structure has significant influence on the firms' financial reporting incentives to report earnings conservatively.

Finally, this study examines whether firms with strong corporate governance report more conservative earnings. The analysis fails to find any significant relationship between corporate governance and earnings conservatism, even though a comprehensive set of corporate governance variables was employed. This result is in conflict with evidence from developed markets, such as the United States and the United Kingdom, where firms with good governance are more timely in recognising bad news. A plausible explanation is that the corporate governance model, which is based on an Anglo-Saxon model, is inappropriate to emerging markets with a substantial number of family-firms. For instance, the appointment of 'independent' directors in family firms is likely to be influenced by the management's close relationship with the prospective directors and the likelihood of their support for the management's philosophy and policies (Chen \& 
Jaggi, 2000). This situation leads to ineffective corporate governance since independent directors are no longer capable of performing their duties independently. Thus family management sets out to ensure conservatism in earnings.

\subsection{Limitations}

Notwithstanding an extensive set of sensitivity analyses, the results of this study are subject to certain limitations and need to be interpreted with caution.

First, the construction of the sample has consequences for the generalisability of the results. All firms that existed from the year 2002 to 2008 have been included as long as the data concerned was consistent with the requirement of the study. Selecting the sample on this basis might lead to survivorship bias because it excludes newly-listed firms and firms that were delisted from the official list of Bursa Malaysia during the study period.

Second, the primary measure for earnings conservatism, the asymmetric timeliness of earnings, is exposed to potential measurement error and bias (Dietrich, et al., 2007) as a result of incorrect inferences.

Third, with regard to the adoption of IFRS, full convergence is scheduled for 1 January 2012. For the period under study, IFRS 4 Insurance Contracts, IFRS 7 Financial Instruments: Disclosures and IFRS 8 Operating Segments were still not effective. Thus extra caution is necessary when interpreting the effect of IFRS on earnings conservatism. The findings of no systematic difference of earnings 
conservatism between the period under the MASB standards and the period under IFRS standards may be a reflection of this overlap.

Fourth, due to the complex ownership structure of Malaysian firms, this study uses a dichotomous variable as the identifier of family firm. The pyramidal and cross-sectional control and the use of nominees make the determination of the 'real percentage' of shares owned by the controlling shareholder a daunting task. The use of nominee accounts by Malaysian investors could also create a measurement bias. Likewise, the lack of a continuous measure for family control might also create a bias.

Fifth, although the alternative measure of family firms includes the percentage of shares owned by the controlling family, some families are nevertheless able to exert control with only a minimal shareholdings, while others require a larger stakes for the same level of control due to differences in firm size, industry, business practices, and product placement (Anderson \& Reeb, 2003b).

Sixth, this study uses corporate governance metrics to identify whether firms have good or poor governance structure. It is important to highlight the note of caution by Armstrong, Guay, and Weber (2010). The authors assert that when classifying governance structure into good or bad, researchers have to ensure that "what is being called a 'bad' structure is not instead a 'good' structure for certain firms" ( $p$. 208). They argue that studies, which identify firms with a relatively higher proportion of outside directors as having a 'good' governance structure, ignore "the extensive economic arguments and empirical evidence ... as to why some 
firms that are labelled as having 'bad' governance might, in fact, have appropriately (endogeneously) selected a board with relatively few outside directors" (Armstrong, et al., 2010, p. 208). Future research should look into the potential interrelationships among various corporate governance mechanisms which would render different mixes of corporate governance mechanism equally effective.

Finally, the analysis has not tested for endogeneity in the relationship between corporate governance and earnings conservatism. This may bias the coefficient estimates and the conclusions that are derived therefrom. To address the endogeneity issue, future studies could employ two-stage least squares estimation of the regression equations (e.g., Heckman, 2000; Imbens \& Wooldridge, 2009). 


\section{References}

Abbott, L. J., Parker, S., \& Peters, G. F. (2004). Audit committee characteristics and restatements. Auditing: A Journal of Practice and Theory, 23(1), 69-87.

Abdul Rahman, R. (2006). Effective corporate governance (1st ed.). Malaysia: University Publication Centre (UPENA) Universiti Teknologi Mara, Malaysia.

Abdul Rahman, R., \& Haniffa, R. M. (2005). The effect of role duality on corporate performance in Malaysia. Corporate Ownership and Control, $2(2), 40-47$.

Abdul Rahman, R., \& Mohamed Ali, F. H. (2006). Board, audit committee, culture and earnings management: Malaysian evidence. Managerial Auditing Journal, 21(7), 783-804.

Abdul Wahab, E. A., How, J. C. Y., \& Verhoeven, P. (2007). Institutional investors, corporate governance and firm performance in Malaysia. Paper presented at the 2nd Journal of Contemporary Accounting and Economic. Symposium Proceedings.

Abdullah, S. N. (2004). Board composition, CEO duality and performance among Malaysian listed companies. Corporate Governance, 4(4), 47-61.

Abdullah, S. N., \& Mohd Nasir, N. (2004). Accrual management and the independence of the board of directors and audit committees. IIUM Journal of Economics and Management, 12(1), 49-80.

Abu-Bakar, N. B., \& Ahmad, M. (2009). Auditor independence: Malaysian accountants' perceptions. International Journal of Business Managament, $4(12), 129-141$.

Ahmed, A. S., Billings, B. K., Morton, R. M., \& Stanford-Harris, M. (2002). The role of accounting conservatism in mitigating bondholder-shareholder conflicts over dividend policy and in reducing debt costs. The Accounting Review, 77(4), 867-890.

Ahmed, A. S., \& Duellman, S. (2007). Accounting conservatism and board of director characteristics: An empirical analysis. Journal of Accounting and Economics, 43(2/3), 411-437.

Akoi, M. (1999). Controlling insider control: Issues of corporate governance in transition economies. In M. Akoi \& H. Kim (Eds.), Corporate Governance 
in Transitional Economies: Insider Control and The Role of Banks. Washington DC: World Bank.

Al-Sehali, M., \& Spear, N. (2004). The decision relevance and timeliness of accounting earnings in Saudi Arabia. The International Journal of Accounting, 39(2), 197-217.

Ali, A., Chen, T., \& Radhakrishnan, S. (2007). Corporate disclosures by family firms. Journal of Accounting and Economics, 44(1/2), 238-286.

Anderson, R. C., Mansi, S. A., \& Reeb, D. M. (2003). Founding family ownership and the agency cost of debt. Journal of Financial Economics, 68(2), 263285.

Anderson, R. C., \& Reeb, D. M. (2003a). Family ownership, corporate diversification, and firm leverage. Journal of Law and Economics, 46(2), 653-684.

Anderson, R. C., \& Reeb, D. M. (2003b). Founding-family ownership and firm performance: Evidence from the S\&P 500. The Journal of Finance, 58(3), 1301-1328.

Ang, J. S., \& Ding, D. K. (2006). Government ownership and the performance of government-linked companies: The case of Singapore. Journal of Multinational Financial Management, 16(1), 64-88.

Arens, A. A., Loebbecke, J. K., Iskandar, T. M., Susela, S. D., \& Isa, S. (1999). Auditing in Malaysia: An integrated approach. Kuala Lumpur, Malaysia: Prentice Hall.

Armstrong, C. S., Guay, W. R., \& Weber, J. P. (2010). The role of information and financial reporting in corporate governance and debt contracting. Journal of Accounting and Economics, 50(2/3), 179-234.

Arosa, B., Iturralde, T., \& Maseda, A. (2010). Ownership structure and firm performance in non-listed firms: Evidence from Spain. Journal of Family Business Strategy, 1(2), 88-96.

Ball, R. (2001). Infrastructure requirements for an economically efficient system of public financial reporting and disclosure. Brookings-Wharton Papers on Financial Services, 127-169.

Ball, R., \& Brown, P. (1968). An empirical evaluation of accounting income numbers. Journal of Accounting Research, 6(2), 159-178. 
Ball, R., Kothari, S. P., \& Robin, A. (2000). The effect of international institutional factors on properties of accounting earnings. Journal of Accounting and Economics, 29(1), 1-51.

Ball, R., Robin, A., \& Wu, J. S. (2003). Incentives versus standards: Properties of accounting income in four East Asian countries. Journal of Accounting and Economics, 36(1/3), 235-270.

Ball, R., \& Shivakumar, L. (2005). Earnings quality in UK private firms: comparative loss recognition timeliness. Journal of Accounting and Economics, 39(1), 83-128.

Ball, R., \& Shivakumar, L. (2006). The role of accruals in asymmetrically timely gain and loss recognition. Journal of Accounting Research, 44(2), 207-242.

Balsam, S., Krishnan, J., \& Yang, J. S. (2003). Auditor industry specialization and earnings quality. Auditing: A Journal of Practice and Theory, 22(2), 71-97.

Barclay, M., \& Smith, C. (1995). The maturity structure of corporate debt. Journal of Finance, 50(2), 609-631.

Barth, M., Landsman, W., \& Lang, M. (2008). International Accounting Standards and accounting quality. Journal of Accounting Research, 46(3), 467.

Basu, S. (1995). Conservatism and the Asymmetric Timeliness of Earnings. Ph.D dissertation, University of Rochester.

Basu, S. (1997). The conservatism principle and the asymmetric timeliness of earnings. Journal of Accounting and Economics, 24(1), 3-37.

Basu, S., Hwang, L., \& Jan, C. (2001). Differences in conservatism between Big Eight and non-Big Eight auditors. Working Paper. Baruch College.

Beasley, M. S., Carcello, J. V., Hermanson, D. R., \& Lapides, P. D. (2000). Fraudulent financial reporting: Consideration of industry traits and corporate governance mechanisms. Accounting Horizons, 14(4), 441-454.

Beaver, W. H., Lambert, R. A., \& Morse, D. (1980). The information content of security prices. Journal of Accounting and Economics, 2(1), 3-28.

Beaver, W. H., \& Ryan, S. G. (2000). Biasses and lags in book value and their effect on the ability of the book-to-market ratio to predict book return on equity. Journal of Accounting Research, 38(1), 127-148. 
Beaver, W. H., \& Ryan, S. G. (2005). Conditional and unconditional conservatism: concepts and modeling. Review of Accounting Studies, $10(2 / 3), 269-276$.

Becker, C. L., Defond, M. L., Jiambolvo, J., \& Subramanyam, K. R. (1998). The effect of audit quality on earnings management. Contemporary Accounting Research, 15(1), 1-24.

Bédard, J., \& Biggs., S. (1991). The effect of domain-specific experience on evaluation of management representation in analytical procedures. Auditing: A Journal of Practice and Theory, 10(Supplement), 77-95.

Bédard, J., Chtourou, S. M., \& Courteau, L. (2004). The effect of audit committee expertise, independence, and activity on aggressive earnings management. Auditing: A Journal of Practice \& Theory, 23(2), 15-37.

Beekes, W., Pope, P. F., \& Young, S. (2004). The link between earnings timeliness, earnings conservatism and board composition: evidence from the UK. Corporate Governance: An International Review, 12(1), 47-59.

Beneish, M. D., \& Press, E. (1993). Costs of technical violation of accountingbased debt covenants. The Accounting Review, 68(2), 233-257.

Bernard, V. L. (1989). Capital market research in accounting during the 1980s: A critical review. In T. J. Frecka (Ed.), The state of accounting research as we enter the 1990's: University of Illinois at Urbana-Champaign.

Bonner, S. E., \& Lewis, B. L. (1990). Determinants of auditor expertise. Journal of Accounting Research, 28(Supplement), 1-20.

Boyd, B. K. (1994). Board control and CEO compensation. Strategic Management Journal, 15(5), 335-344.

Brooks, L., \& Buckmaster, D. (1976). Further evidence of the time series properties of accounting income. The Journal of Finance, 31(5), 13591373.

Brunello, G., Graziano, C., \& Parigi, B. M. (2003). CEO turnover in insider dominated boards: The Italian case. Journal of Banking and Finance, 27, 1027-1051.

Burkart, M., Gromb, D., \& Panunzi, F. (1997). Large shareholders, monitoring, and the value of the firm. The Quarterly Journal of Economics, 112(3), 693-728. 
Bushman, R. M., \& Piotroski, J. D. (2006). Financial reporting incentives for conservative accounting: The influence of legal and political institutions. Journal of Accounting and Economics, 42(1/2), 107-148.

Byrd, J. W., \& Hickman, K. A. (1992). Do outside directors monitor managers? Evidence from tender offer bids. Journal of Financial Economics, 32(2), 195-221.

Cadbury Committee. (1992). Report of the committee on the financial aspects of corporate governance (With the code of best practice). London: Gee Publishing.

Cahan, S. F., \& Zhang, W. (2006). After Enron: Auditor conservatism and exAndersen clients. The Accounting Review, 81(1), 49-82.

Callen, J., Segal, D., \& Hope, O.-K. (2010). The pricing of conservative accounting and the measurement of conservatism at the firm-year level. Review of Accounting Studies, 15(1), 145-178.

Capulong, M. V., Edwards, D., Webb, D., \& Zhuang, J. (2001). Corporate governance and finance in East Asia: A study of Indonesia, Republic of Korea, Malaysia, Philippines, and Thailand: Volume one. Manila: Asian Development Bank.

Carcello, J. V., \& Neal, T. L. (2000). Audit committee composition and auditor reporting. The Accounting Review, 75(4), 453-467.

Casson, M. C. (1999). The economics of the family firm. Scandinavian Economic History Review, 47(1), 10-23.

Chandra, U., Wasley, C., \& Waymire, G. (2004). Income conservatism in the U.S. technology sector. Working paper. University of Rochester.

Chau, G., \& Gray, S. J. (2010). Family ownership, board independence and voluntary disclosure: Evidence from Hong Kong. Journal of International Accounting, Auditing and Taxation, 19(2), 93-109.

Che Haat, M. H. (2006). The effect of corporate governance on transparency and performance of Malaysian companies. $\mathrm{PhD}$ Unpublished Dissertation, Universiti Teknologi Mara, Malaysia.

Chen, C. J. P., \& Jaggi, B. (2000). Association between independent nonexecutive directors, family control and financial disclosures in Hong Kong. Journal of Accounting and Public Policy, 19(4/5), 285-310. 
Chen, T. (2005). Executive compensation contracts of family firms. Working paper. Working paper. University of Texas at Dallas.

Chung, R., Firth, M., \& Kim, J.-B. (2003). Auditor conservatism and reported earnings. Accounting and Business Research, 33(1), 19-32.

Claessens, S., Djankov, S., \& Lang, L. H. P. (2000). The separation of ownership and control in East Asian corporations. Journal of Financial Economics, 58(1/2), 81-112.

Coles, J. L., Daniel, N. D., \& Naveen, L. (2008). Boards: Does one size fit all? Journal of Financial Economics, 87(2), 329-356.

Collier, P. (1993). Factors affecting the formation of audit committees in major UK listed companies. Accounting and Business Research, 23(91A), 421430.

Conyon, M. J., \& Peck, S. I. (1998). Board size and corporate performance: evidence from European countries. The European Journal of Finance, 4(3), 291-304.

Davila, A., \& Penalva, F. (2006). Governance structure and the weighting of performance measures in CEO compensation. Review of Accounting Studies, 11(4), 463-493.

DeAngelo, L. E. (1981). Auditor size and audit quality. Journal of Accounting and Economics, 3(3), 183-199.

DeFond, M. L., \& Subramanyam, K. R. (1998). Auditor changes and discretionary accruals. Journal of Accounting and Economics, 25(1), 35-67.

Demsetz, H., \& Lehn, K. (1985). The structure of corporate ownership: Causes and consequences. The Journal of Political Economy, 93(6), 1155-1577.

Devalle, A., Onali, E., \& Magarini, R. (2010). Assessing the value relevance of accounting data after the introduction of IFRS in Europe. Journal of International Financial Management \& Accounting, 21(2), 85-119.

Dietrich, J., Muller, K., \& Riedl, E. (2007). Asymmetric timeliness tests of accounting conservatism. Review of Accounting Studies, 12(1), 95-124.

Dopuch, N., \& D. Simunic. (1980). The nature of competition in the auditing profession: a descriptive and normative view. In J. Buckley \& F. Weston (Eds.), Regulation and the Accounting Profession (pp. 77-94). Belmont, CA: Lifetime Learning Publications. 
Downs, A. (1957). An economic theory of democracy. New York: HarperCollins.

Easley, D., Hvidkjaer, S., \& O'Hara, M. (2002). Is information risk a determinant of asset returns? The Journal of Finance, 57(5), 2185-2221.

Easton, P., \& Pae, J. (2004). Accounting conservatism and the relation between returns and accounting data. Review of Accounting Studies, 9(4), 495-521.

Economic Planning Unit Prime Minister's Department of Malaysia. (1985). Guidelines on Privatization. Kuala Lumpur: National Printing Department.

Economic Planning Unit Prime Minister's Department of Malaysia. (1991). Privatization Master Plan Kuala Lumpur: National Printing Department.

Eisenberg, T., Sundgren, S., \& Wells, M. T. (1998). Larger board size and decreasing firm value in small firms. Journal of Financial Economics, 48(1), 35-54.

Elgers, P. T., \& Lo, M. H. (1994). Reduction in analysts' annual earnings forecast errors using information in prior earnings and security returns. Journal of Accounting Research, 32(2), 290-303.

Ernst, U. F. W. (2004). Methods for resolving problems of responsibility and transparency in the activities of SOEs in market economies: Models and results. Corporate Ownership and Control, 1(3), 37-43.

Faccio, M., \& Lang, L. H. P. (2002). The ultimate ownership of Western European corporations. Journal of Financial Economics, 65(3), 365-395.

Fadzly, M. N., \& Ahmad, Z. (2004). Audit expectation gap: The case of Malaysia. Managerial Auditing Journal, 19 (7), 897-915.

Fama, E. F. (1980). Agency problems and the theory of the firm. Journal of Political Economy, 88(2), 288-307.

Fama, E. F., \& Jensen, M. C. (1983). Separation of ownership and control. Journal of Law and Economics, 26(2), 301-325.

Fama, E. F., \& MacBeth, J. (1973). Risk, return, and equilibrium: empirical tests. Journal of Political Economy, 81(3), 607-636.

Fan, J. P. H., \& Wong, T. J. (2002). Corporate ownership structure and the informativeness of accounting earnings in East Asia. Journal of Accounting and Economics, 33(3), 401-425. 
Feldmann, D. A., \& Schwarzkopf, D. L. (2003). The effect of institutional ownership on board and audit committee composition. Review of Accounting \& Finance, 2(4), 87-109.

Feltham, G. A., \& Ohlson, J. A. (1995). Valuation and clean surplus accounting for operating and financial activities. Contemporary Accounting Research, 11(2), 689-731.

Finance Committee on Corporate Governance. (1999). Report on corporate governance (pp. 1-275). Kuala Lumpur: Securities Commission.

Finance Committee on Corporate Governance. (2000). Malaysian Code on Corporate Governance (pp. 1-50). Kuala Lumpur, Malaysia: Securities Commission.

Fischer, S. (1998). The Asian Crisis and the Changing Role of the IMF. IMF Finance and Development, 35(2). Retrieved from http://www.imf.org/external/pubs/ft/fandd/1998/06/fischer.htm

Foon, H. W. (1997, November 19). Investors give thumbs down to UEM's Renong purchase, The Straits Times, p. 62.

Francis, J., LaFond, R., Olsson, P., \& Schipper, K. (2004). Cost of equity and earnings attributes. The Accounting Review, 79, 967-1010.

Francis, J., Schipper, K., \& Vincent, L. (2005). Earnings and dividends informativeness when cash flow rights are separated from voting rights. Journal of Accounting and Economics, 39(2), 329-360.

Francis, J. R., Maydew, E. L., \& Sparks, H. C. (1999). The role of big-six auditors in the credible reporting of accruals. Auditing: A Journal of Practice and Theory, 18(2), 17-34.

Francis, J. R., \& Simon, D. T. (1987). A test of audit pricing in the small-client segment of the U. S. audit market. The Accounting Review, 62(1), 145-157.

García Lara, J. M., García Osma, B., \& Penalva, F. (2007). Board of directors' characteristics and conditional accounting conservatism: Spanish evidence. European Accounting Review, 16(4), 727 - 755.

García Lara, J. M., García Osma, B., \& Penalva, F. (2009). Accounting conservatism and corporate governance Review of Accounting Studies, 14(1), 161-201.

García Lara, J. M., \& Mora, A. (2004). Balance sheet versus earnings conservatism in Europe. European Accounting Review, 13(2), 261-292. 
Gassen, J., Fülbier, R. U., \& Sellhorn, T. (2006). International differences in conditional conservatism: The role of unconditional conservatism and income smoothing. European Accounting Review, 15(4), 527-564.

Gaver, J., Gaver, K., \& Austin, J. (1995). Additional evidence on bonus plans and income management. Journal of Accounting and Economics, 19(1), 3-28.

Gigler, F. B., \& Hemmer, T. (2001). Conservatism, optimal disclosure policy, and the timeliness of financial reports. The Accounting Review, 76(4), 471.

Giner, B., \& Rees, W. (2001). On the asymmetric recognition of good and bad news in France, Germany and the United Kingdom. Journal of Business, Finance and Accounting, 28(9), 1285-1331.

Givoly, D., \& Hayn, C. (2000). The changing time-series properties of earnings, cash flows and accruals: Has financial reporting become more conservative? Journal of Accounting and Economics, 29(3), 287-320.

Gompers, P. A., Ishii, J. L., \& Metrick, A. (2003). Corporate governance and equity prices. Quarterly Journal of Economics, 118(1), 107-155.

Grambovas, C. A., Giner, B., \& Christodoulou, D. (2006). Earnings conservatism: panel data evidence from the European Union and the United States. Abacus, 42(3/4), 354-378.

Guidry, F., Leone, A., \& Rock, S. (1999). Earnings-based bonus plans and earnings management by business unit managers. Journal of Accounting and Economics, 26(1/3), 113-142.

Gujarati, D. N. (2004). Basic Econometrics (Fourth ed.). New York: McGrawHill Inc.

Gul, F. A., Tsui, J. S. L., \& Dhaliwal, D. S. (2006). Non-audit services, auditor quality and the value relevance of earnings. Accounting and Finance, 46(5), 797-817.

Hair, J. F., Black, W. C., Babin, R. E., Anderson, R. E., \& Tatham, R. L. (2006). Multivariate data analysis (6th ed.). New Jersey: Pearson Education Inc.

Hampel Committee. (1998). Committee on corporate governance: Final report. London: Gee Publishing.

Healy, P. M. (1985). The effect of bonus schemes on accounting decisions. Journal of Accounting and Economics, 7(1/3), 85-107. 
Heckman, J. J. (2000). Causal parameters and policy analysis in economics: A twentieth century retrospective. Quarterly Journal of Economics, 115(1), 45-97.

Hellman, N. (2008). Accounting conservatism under IFRS. Accounting in Europe, $5(2), 71-100$.

Heninger, W. G. (2001). The association between auditor litigation and abnormal accruals. The Accounting Review, 76(1), 111-126.

Hermalin, B. E., \& Weisbach, M. S. (2003). Boards of directors as an endogenously determined institution: A survey of the economic literature. Economic Policy Review, 9, 7-26.

Ho, S. S. M., \& Wong, K. S. (2001). A study of the relationship between corporate governance structures and the extent of voluntary disclosure. Journal of International Accounting, Auditing and Taxation, 10(2), 139-156.

Huijgen, C., \& Lubberink, M. (2005). Earnings conservatism, litigation and contracting: The case of cross-listed firms. Journal of Business Finance and Accounting, 32(7/8), 1275-1309.

IASB. (2010). The Conceptual Framework for Financial Reporting. In I. A. S. Board (Ed.). London: International Accounting Standards Board.

IASC. (1989). Framework for the Preparation and Presentation of Financial Statements: International Accounting Standards Committee.

Imbens, G. W., \& Wooldridge, J. M. (2009). Recent developments in the econometrics of program evaluation. Journal of Economic Literature, 47(1), $5-86$.

Jaggi, B., Leung, S., \& Gul, F. (2009). Family control, board independence and earnings management: Evidence based on Hong Kong firms. Journal of Accounting and Public Policy, 28(4), 281-300.

James, H. (1999). Owner as a manager, extended horizons and the family firm. International Journal of Economics of Business, 6(1), 41-56.

Jenkins, D. S., \& Velury, U. (2008). Does auditor tenure influence the reporting of conservative earnings? Journal of Accounting and Public Policy, 27(2), $115-132$.

Jensen, M. C. (1993). The modern industrial revolution, exit, and the failure of internal control systems. The Journal of Finance, 48(3), 831-880. 
Jensen, M. C., \& Meckling, W. H. (1976). Theory of the firm: Managerial behavior, agency costs and ownership structure. Journal of Financial Economics, 3(4), 305-360.

Jeong, S. W., \& Rho, J. (2004). Big Six auditors and audit quality: The Korean evidence. The International Journal of Accounting, 39(2), 175-196.

Johnson, S., Boone, P., Breach, A., \& Friedman, E. (2000). Corporate governance in the Asian financial crisis, 1997-98 Journal of Financial Economics, 58, 141-186.

Johnson, V. E., Khurana, I. K., \& Reynolds, J. K. (2002). Audit-firm tenure and the quality of financial reports. Contemporary Accounting Research, 19(4), 637-660.

Kawai, M., Newfarmer, R., \& Schmukler, S. (2001). Crisis and contagion in East Asia: Nine lessons. World Bank Policy Research Working Paper, WPS2610.

Kellogg, R. L. (1984). Accounting activities, security prices, and class action lawsuits. Journal of Accounting and Economics, 6(3), 185-204.

Khan, M., \& Watts, R. L. (2009). Estimation and empirical properties of a firmyear measure of accounting conservatism. Journal of Accounting and Economics, 48(2/3), 132-150.

Kothari, S. P., \& Sloan, R. G. (1992). Information in prices about future earnings: Implications for earnings response coefficients. Journal of Accounting and Economics, 15(2/3), 143-171.

Kothari, S. P., \& Zimmerman, J. L. (1995). Price and return models. Journal of Accounting and Economics, 20(2), 155-192.

Krishnan, G. V. (2003). Does Big 6 auditor industry expertise constrain earnings management? Accounting Horizons, 17(Supplement), 1-16.

Krishnan, G. V. (2005a). The association between Big 6 auditor industry expertise and the asymmetric timeliness of earnings. Journal of Accounting, Auditing and Finance, 20(3), 209-228.

Krishnan, G. V. (2005b). Did Houston clients of Arthur Andersen recognize publicly available bad news in a timely fashion? Contemporary Accounting Research, 22(1), 165-193.

Krishnan, G. V. (2007). Did earnings conservatism increase for former Andersen clients? Journal of Accounting, Auditing and Finance, 22(2), 141-163. 
Kwon, S. S., Yin, Q. J., \& Han, J. (2006). The effect of differential accounting conservatism on the "over-valuation" of high-tech firms relative to low-tech firms. Review of Quantitative Finance and Accounting, 27(2), 143-173.

La Porta, R., Lopez-de-Silanes, F., \& Shleifer, A. (1999). Corporate ownership around the world. The Journal of Finance, 54(2), 471-517.

La Porta, R., Lopez-de-Silanes, F., Shleifer, A., \& Vishny, R. (2000). Investor protection and corporate governance. Journal of Financial Economics, 58, $3-27$.

La Porta, R., Lopez-de-Silanes, F., Shleifer, A., \& Vishny, R. W. (1998). Law and finance. Journal of Political Economy, 106(6), 1113-1155.

LaFond, R., \& Watts, R. L. (2008). The information role of conservatism. The Accounting Review, 83(2), 447-478.

Lai, C., \& Taylor, S. L. (2008). Estimating and Validating a Firm-Year Specific Measure of Conservatism: Australian Evidence. Accounting and Finance, 48, 673-695.

Lang, M., Raedy, J., \& Wilson, W. (2006). Earnings management and cross listing: Are reconciled earnings comparable to US earnings. Journal of Accounting \& Economics, 42, 255-283.

Lang, M., Raedy, J., \& Yetman, M. (2003). How representative are firms that are cross-listed in the United States? An analysis of accounting quality. Journal of Accounting Research, 41(2), 363-386.

Larcker, D. F., Richardson, S. A., \& Tuna, I. (2007). Corporate governance, accounting outcomes, and organizational performance. The Accounting Review, 82(4), 963-1008.

Lau, Y. W., \& Tong, C. Q. (2008). Are Malaysian Government-Linked Companies (GLCs) creating value? International Applied Economics and Management Letters, 1(1), 9-12.

Liew, P. K. (2007). Corporate governance reforms in Malaysia: The key leading players' perspectives. Corporate Governance, 15(5), 724-740.

Lin, J. W., Li, J. F., \& Yang, J. S. (2006). The effect of audit committee performance on earnings quality. Managerial Auditing Journal, 21(9), 921933.

Linck, J. S., Netter, J. M., \& Yang, T. (2008). The determinants of board structure. Journal of Financial Economics, 87(2), 308-328. 
Lobo, G. J., \& Zhou, J. (2006). Did conservatism in financial reporting increase after the Sarbanes-Oxley Act? Initial evidence. Accounting Horizons, 20(1), $57-73$.

MCCG. (2000). Malaysian Code on Corporate Governance. Kuala Lumpur, Malaysia: Securities Commission.

MCCG. (2007). Malaysian Code on Corporate Governance (Revised 2007). Kuala Lumpur, Malaysia: Securities Commission.

Menon, K., \& Williams, J. (1994). The use of audit committees for monitoring. Journal of Accounting and Public Policy, 13(2), 121-139.

Miller, D., \& Le Breton-Miller, I. (2006). Family governance and firm performance: Agency, stewardship, and capabilities. Family Business Review, 19(1), 73-87.

Miller, G. S. (2004). Discussion of what determines corporate transparency. Journal of Accounting Research, 42(2), 253-268.

Miller, M. H., \& Luangaram, P. (1998). Financial crisis in East Asia: Bank runs, asset bubbles and antidotes. CSGR Working Paper. University of Warwick.

Morck, R., Shleifer, A., \& Vishny, R. W. (1988). Management ownership and market valuation: An empirical analysis. Journal of Financial Economics, 20, 293-315.

Morck, R., Yeung, B., \& Yu, W. (2000). The information content of stock markets: why do emerging markets have synchronous stock price movements? Journal of Financial Economics, 58(1/2), 215-260.

Morris, R. D., Pham, T. A. M., \& Gray, S. J. (2011). The value relevance of transparency and corporate governance in Malaysia before and after the Asian financial crisis. Abacus, 47(2), 205-233.

Myers, S. (1977). Determinants of corporate borrowing. Journal of Financial Economics, 5(2), 147-175.

Nathan, R. S., Lin, C. S., \& Fong, S. W. (2000). Country paper for Malaysia. Paper presented at the 2nd Asian Roundtable on Corporate Governance, Hong Kong.

O'Keefe, T. B., King, R. D., \& Gaver, K. M. (1994). Audit fees, industry specialization, and compliance with GAAS reporting standards. Auditing: A Journal of Practice and Theory, 13(2), 41-55. 
Ow-Yong, K., \& Kooi Guan, C. (2000). Corporate governance codes: a comparison between Malaysia and the UK. Corporate Governance: An International Review, 8(2), 125-132.

Pallant, J. (2007). SPSS survival manual: A step by step guide to data analysis using SPSS for Windows (Version 15). NSW: Allen \& Unwin.

Palmrose, Z.-V. (1988). An analysis of auditor litigation and audit service quality. The Accounting Review, 63(1), 55-73.

PCG. (2005). Catalysing GLC Transformation to Advance Malaysia's Development Kuala Lumpur: Putrajaya Committee - GLC High Performance.

Penman, S. H., \& Zhang, X.-J. (2002). Accounting conservatism, the quality of earnings, and stock returns. The Accounting Review, 77(2), 237-264.

Pincus, K., Rusbarsky, M., \& Wong, J. (1989). Voluntary formation of corporate audit committees among NASDAQ firms. Journal of Accounting and Public Policy, 8(4), 239-265.

Poon, S. H. (2000). Malaysia and the Asian financial crisis: A view from the finance perspective. African Finance Journal, 2(1), 13-24.

Pope, P. F., \& Walker, M. (1999). International differences in the timeliness, conservatism, and classification of earnings. Journal of Accounting Research, 37(3), 53-87.

Pope, P. F., \& Walker, M. (2003). Ex-ante and ex-post accounting conservatism, asset recognition and asymmetric earnings timeliness. Working Paper. Lancaster University/University of Manchester.

Qiang, X. (2007). The effects of contracting, litigation, regulation, and tax costs on conditional and unconditional conservatism: Cross-sectional evidence at the firm level. The Accounting Review, 82(3), 759-796.

Rajan, R., \& Zingales, L. (1998). Which capitalism? Lessons from the East Asian crisis. Journal of Applied Corporate Finance, 11, 40-48.

Raonic, I., McLeay, S., \& Asimakopoulos, I. (2004). The timeliness of income recognition by European companies: An analysis of institutional and market complexity. Journal of Business, Finance and Accounting, 31(1/2), 151165 .

Richardson, G., \& Tinaikar, S. (2004). Accounting based valuation models: what have we learned? Accounting \& Finance, 44(2), 223-255. 
Rodriguez, G. C., Espejo, C. A., \& Cabrera, R. V. (2007). Incentives management during privatization: An agency perspective. Journal of Management Studies, 44(4), 536-560.

Roe, J. M. (1991). Political theory of American corporate finance. Columbia Law Review, 91(1), 10-67.

Rosenstein, S., \& Wyatt, J. G. (1990). Outside directors, board independence, and shareholder wealth. Journal of Financial Economics, 26(2), 175-191.

Roychowdury, S., \& Watts, R. L. (2007). Asymmetric timeliness of earnings, market-to-book and conservatism in financial reporting. Journal of Accounting and Economics, 44(1/2), 2-31.

Ruddock, C., Taylor, S. J., \& Taylor, S. L. (2006). Nonaudit services and earnings conservatism: is auditor independence impaired? Contemporary Accounting Research, 23(3), 701-746.

Ryan, S. G. (2006). Identifying conditional conservatism. European Accounting Review, 15(4), 511-525.

Saleh, N. M., Iskandar, T. M., \& Rahmat, M. M. (2005). Earnings management and board characteristics: Evidence from Malaysia. Jurnal Pengurusan, 24(4), 77-103.

Salleh, M. F. M. (2009). Political influence, corporate governance and financial reporting quality: Evidence from companies in Malaysia. $\mathrm{PhD}$ Thesis, Massey University, Wellington.

Schroeder, L. D., Sjoquist, D. L., \& Stephan, P. E. (1986). Understanding regression analysis: An introductory guide. California: Sage Publications Inc.

Selvaraj, D. S. (1999). "Interests" and accounting standard setting in Malaysia. Accounting, Auditing \& Accountability Journal, 12(3), 358-387.

Shamsir Jasani Grant Thornton, \& Malaysian Institute of Management. (2002). The family and the business: International survey report. Kuala Lumpur: Shamsir Jasani Grant Thornton \& Malaysian Institute of Management.

Shleifer, A., \& Vishny, R. W. (1994). Politicians and firms. The Quarterly Journal of Economics, 109(4), 995-1025.

Sivakumar, K., \& Waymire, G. (2003). Enforceable accounting rules and income measurement by early 20th century railroads. Journal of Accounting Research, 41(2), 397-432. 
Smith, C., \& Watts, R. L. (1992). The investment opportunity set and corporate financing, dividend and compensation policies. Journal of financial economics, 32(3), 263-292.

St. Pierre, K., \& Anderson, J. (1984). An analysis of the factors associated with lawsuits against public accountants. The Accounting Review, 59(2), 242263.

Sterling, R. R. (1967). Conservatism: The fundamental principle of valuation in traditional accounting. Abacus, 3(2), 109-132.

Tam, O. K., \& Tan, M. G. S. (2007). Ownership, governance and firm performance in Malaysia. Corporate Governance, 15(2), 208-222.

Teoh, S. H., \& Wong, T. J. (1993). Perceived auditor quality and the earnings response coefficient. The Accounting Review, 68(2), 346-366.

Thillainathan, R. (1999). Corporate governance and restructuring in Malaysia - a review of markets, mechanisms, agents and the legal infrastructure Joint World Bank/OECD Survey of Corporate Governance Arrangements in a selected number of Asian countries.

Thoman, L. (1996). Legal damages and auditor efforts. Contemporary Accounting Research, 13(1), 275-306.

Turpin, R. A., \& DeZoort, F. T. (1998). Characteristics of firms that include an audit committee report in their annual report. International Journal of Auditing, 2, 35-48.

UNCSD. (2002). Sustainable development governance. Working Paper for consideration in the Second Week of Third Session of the Preparatory Committee for World Summit for Sutainable Development 2002, retrieved from http://www/johanesburgsummit.org/html/documents/prepcom3docs/governa nce30.3.rev1.doc.

Vafeas, N. (1999). Board meeting frequency and firm performance. Journal of Financial Economics, 53(1), 113-143.

Villalonga, B., \& Amit, R. (2006). How do family ownership, control and management affect firm value? Journal of Financial Economics, 80(2), $385-417$.

Walker, R. G. (1992). The SEC's ban on upward asset revaluations and the disclosure of current values. Abacus, 28(1), 3-35. 
Wall Street Journal. (2002, 6 February). Accounting faces calls for change. Wall Street Journal.

Wan Hussin, W. N., \& Ibrahim, M. A. (2003). Striving for quality financial reporting. Akauntan Nasional, March, 18-24.

Wang, D. (2006). Founding family ownership and earnings quality. Journal of Accounting Research, 44(3), 619-656.

Wang, R., Ó Hógartaigh, C., \& van Zijl, T. (2009). Measures of accounting conservatism: A construct validity perspective. Journal of Accounting Literature, 28, 165-203.

Watts, R. L. (2003a). Conservatism in accounting part I: Explanations and implications. Accounting Horizons, 17(3), 207-221.

Watts, R. L. (2003b). Conservatism in accounting part II: Evidence and research opportunities. Accounting Horizons, 17(4), 287-301.

White, H. (1980). A heteroskedasticity-consistent covariance matrix estimator and a direct test for heteroskedasticity. Econometrica, 48(4), 817-838.

World Bank. (1999). Report on the Observance of Standards and Codes (ROSC) on Malaysia: World Bank.

Yatim, P., Kent, P., \& Clarkson, P. (2006). Governance structures, ethnicity, and audit fees of Malaysian listed firms. Managerial Auditing Journal, 21(7), 757-782.

Yen, J. W., Chun, L. S., Abidin, S. Z., \& Noordin, B. A. A. (2007). Earnings management practices between government linked and Chinese family linked companies. International Journal of Economics and Management, 1(3), 387-406.

Yermack, D. (1996). Higher market valuation of companies with a small board of directors. Journal of Financial Economics, 40(2), 185-211.

Zhang, J. (2008). The contracting benefits of accounting conservatism to lenders and borrowers. Journal of Accounting and Economics, 45(1), 27-54.

Zhuang, J. (1999). Corporate governance in East Asia and some policy implications, EDRC briefing notes number (Vol. 14): Asian Development Bank. 


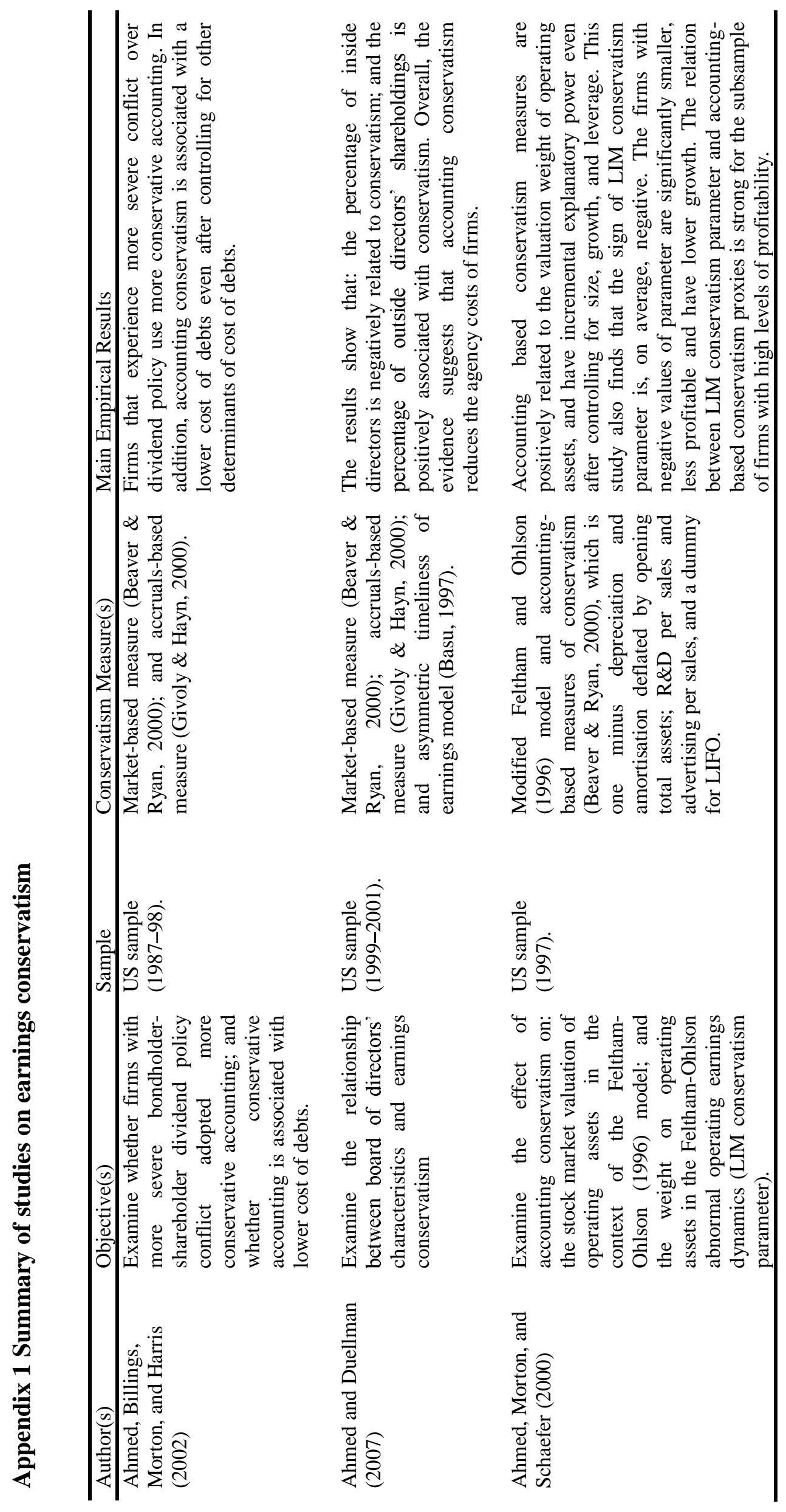

กั 


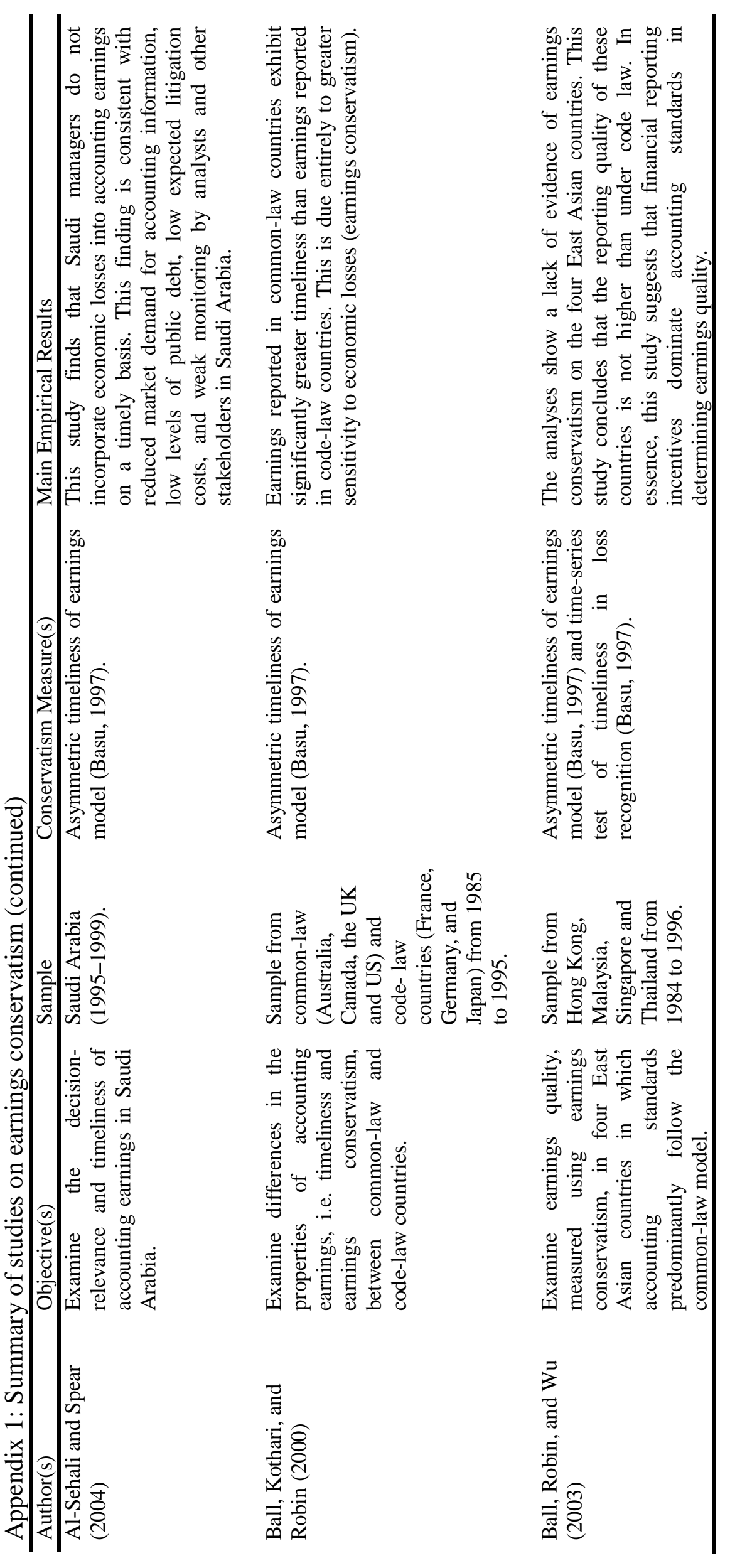




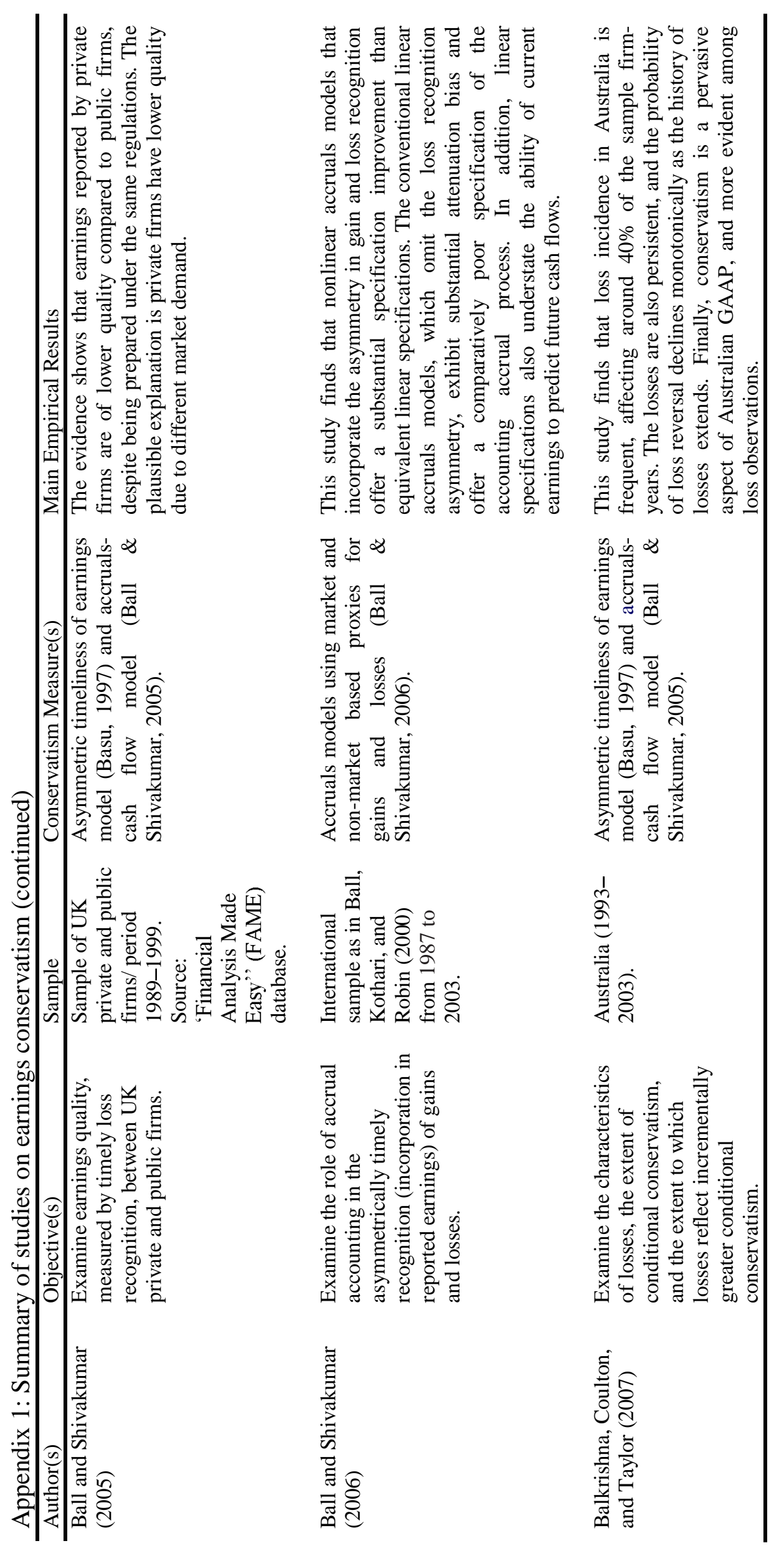




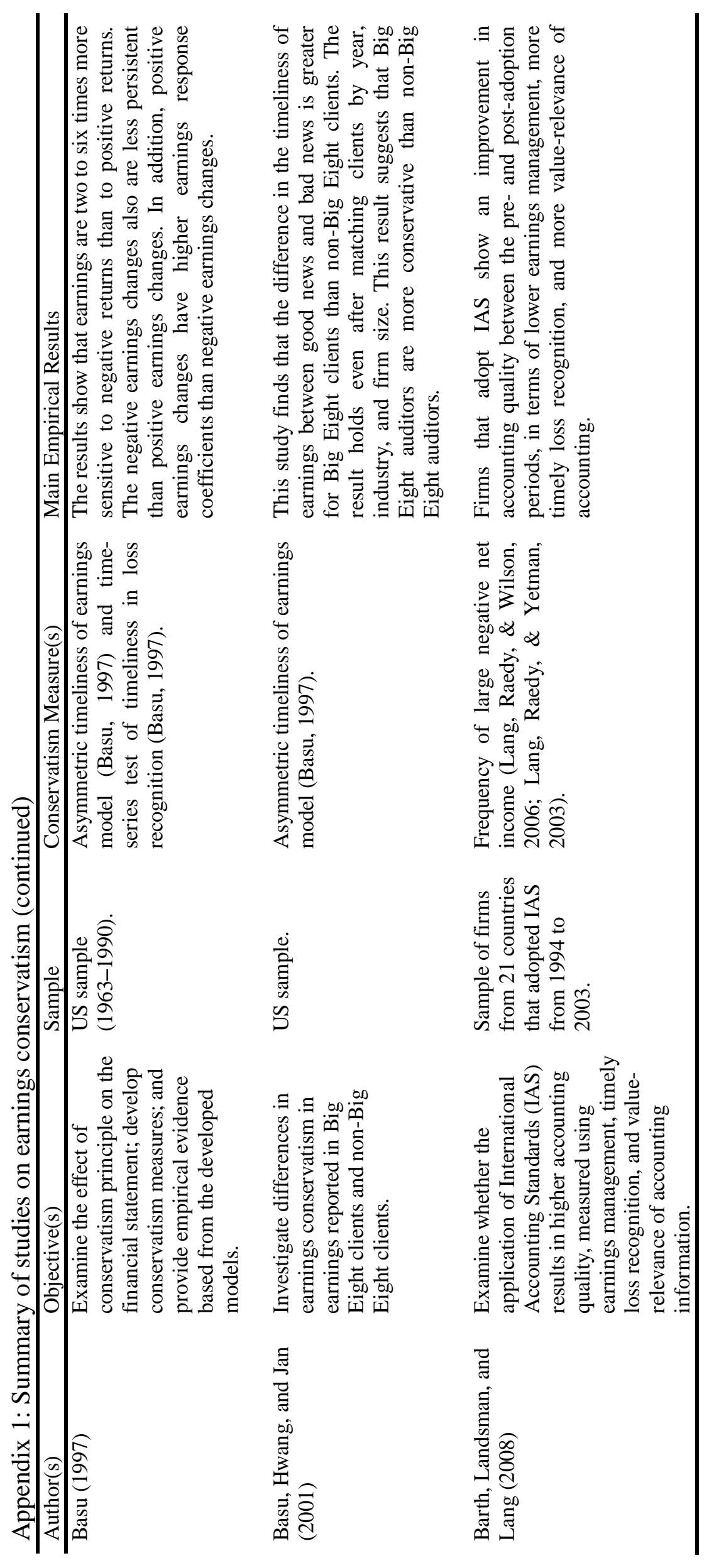

ร 


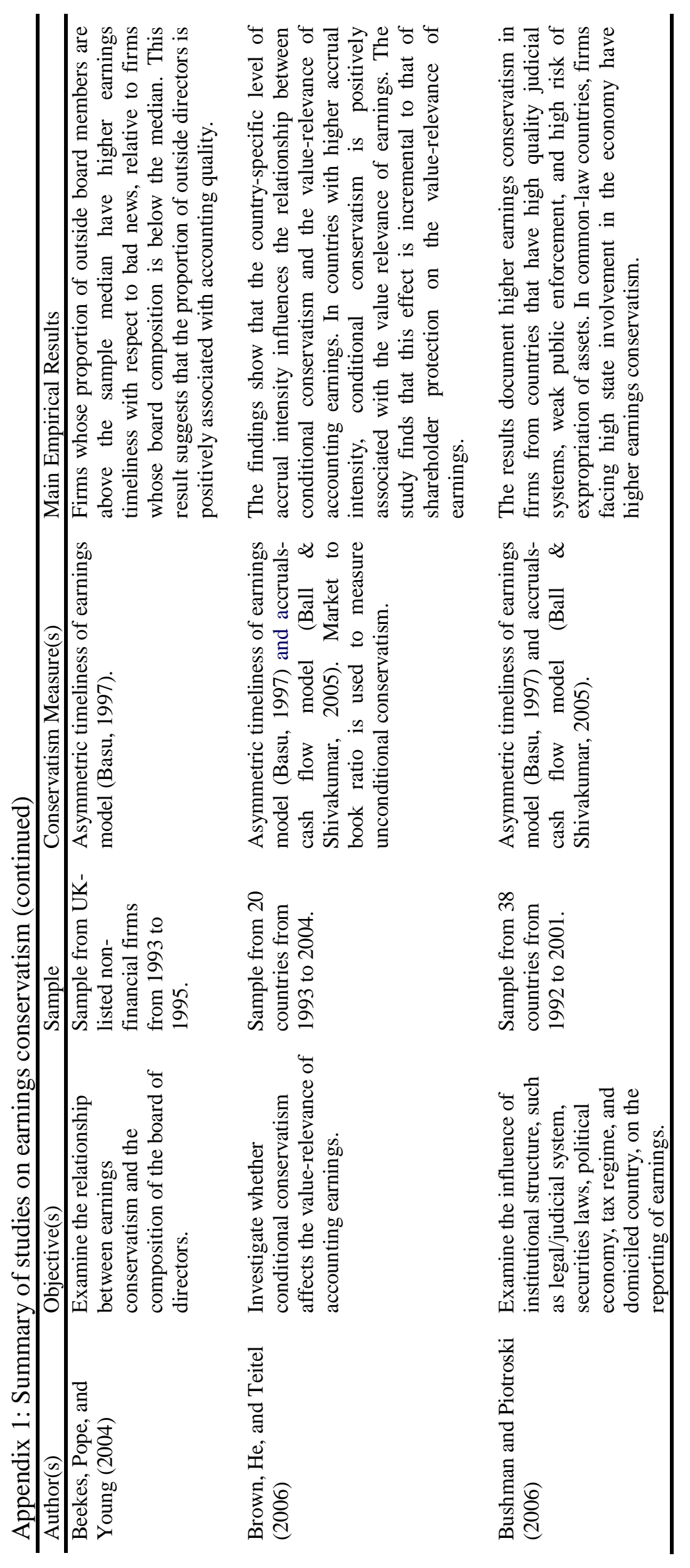

๙ 


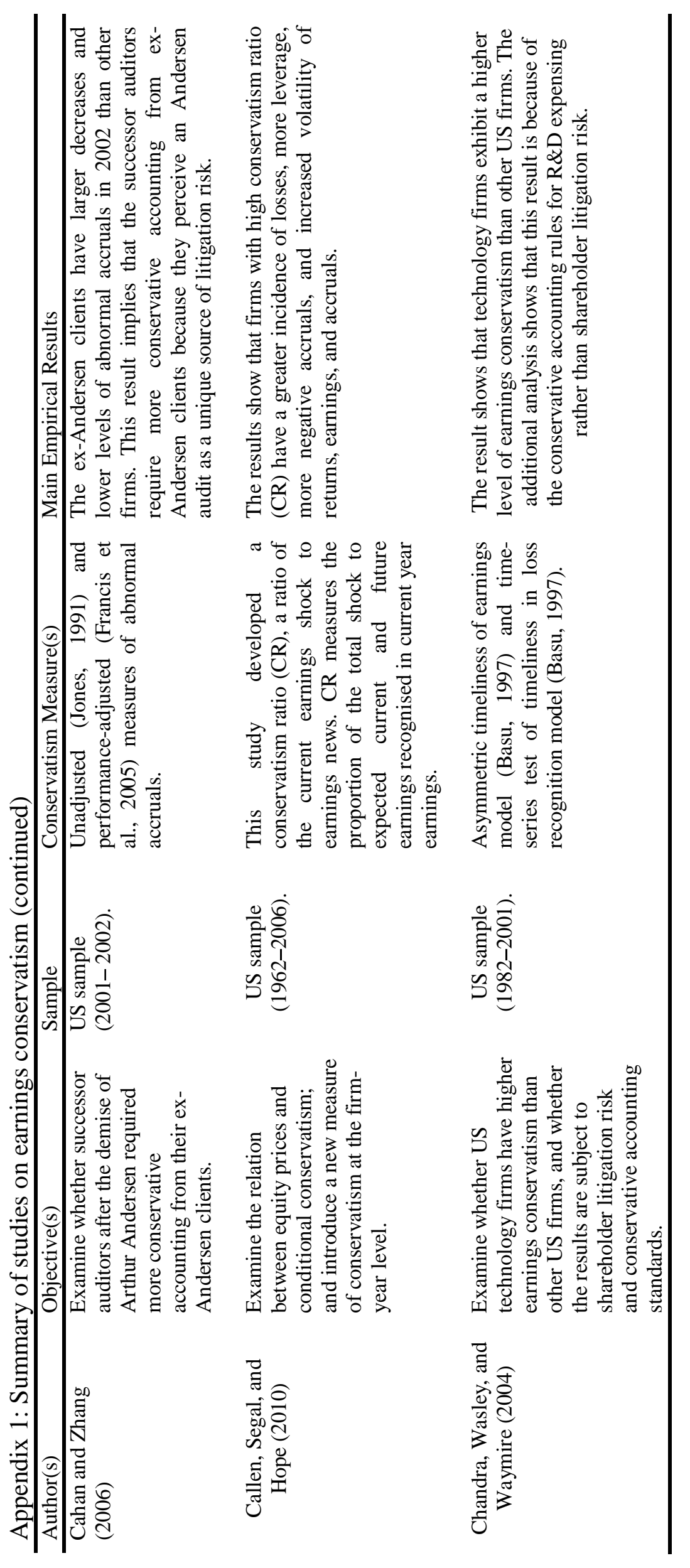

ले 


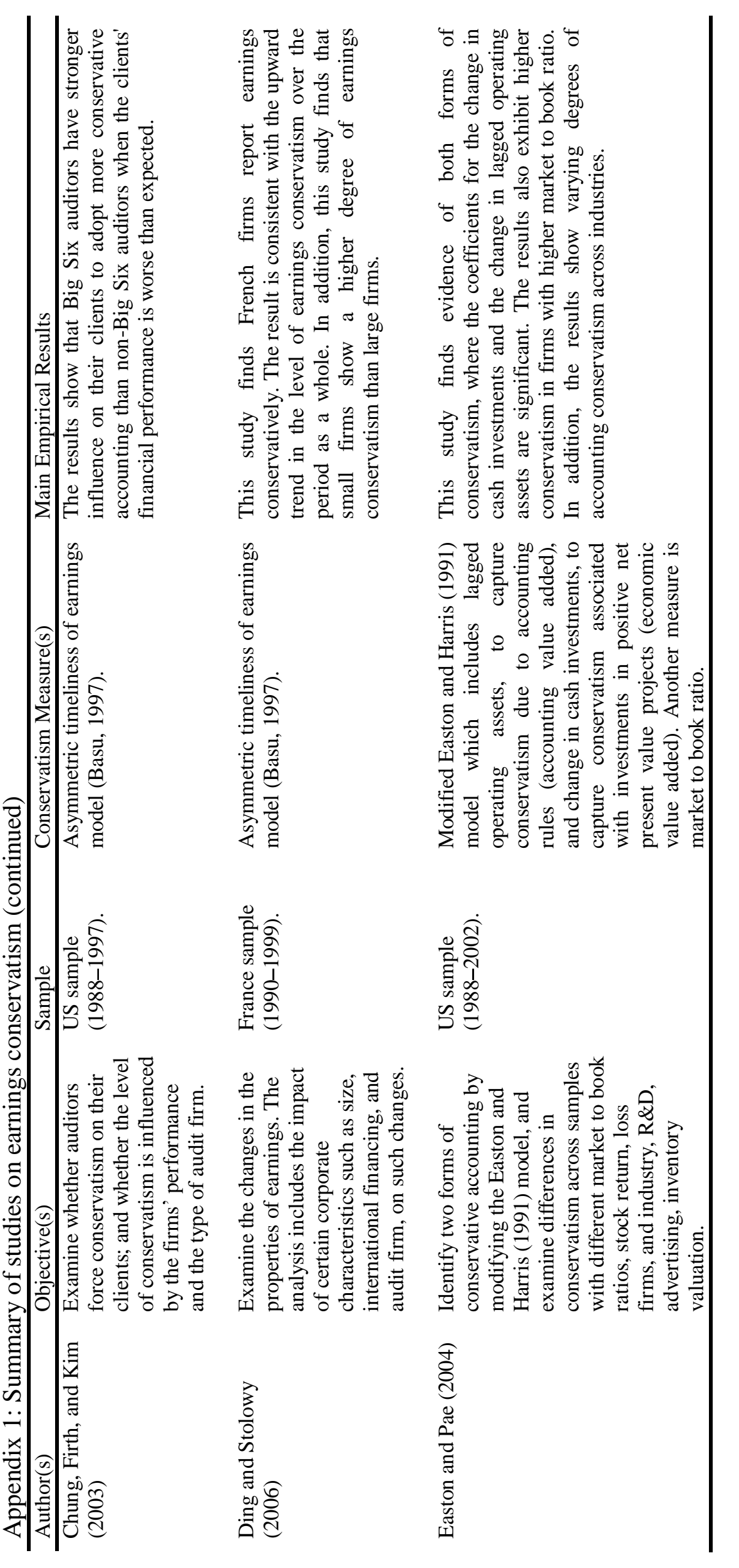

욱 


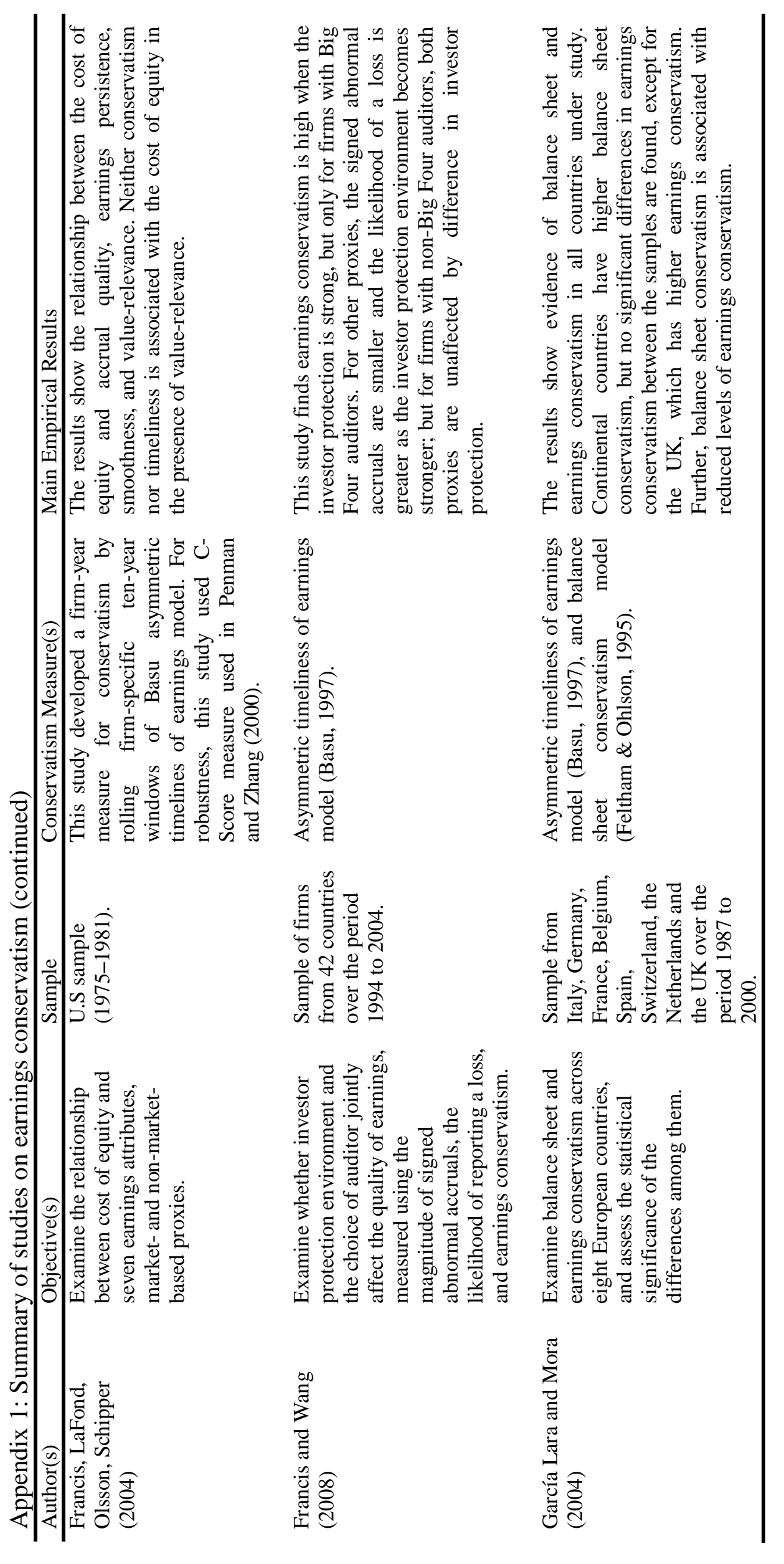

ㄱ 


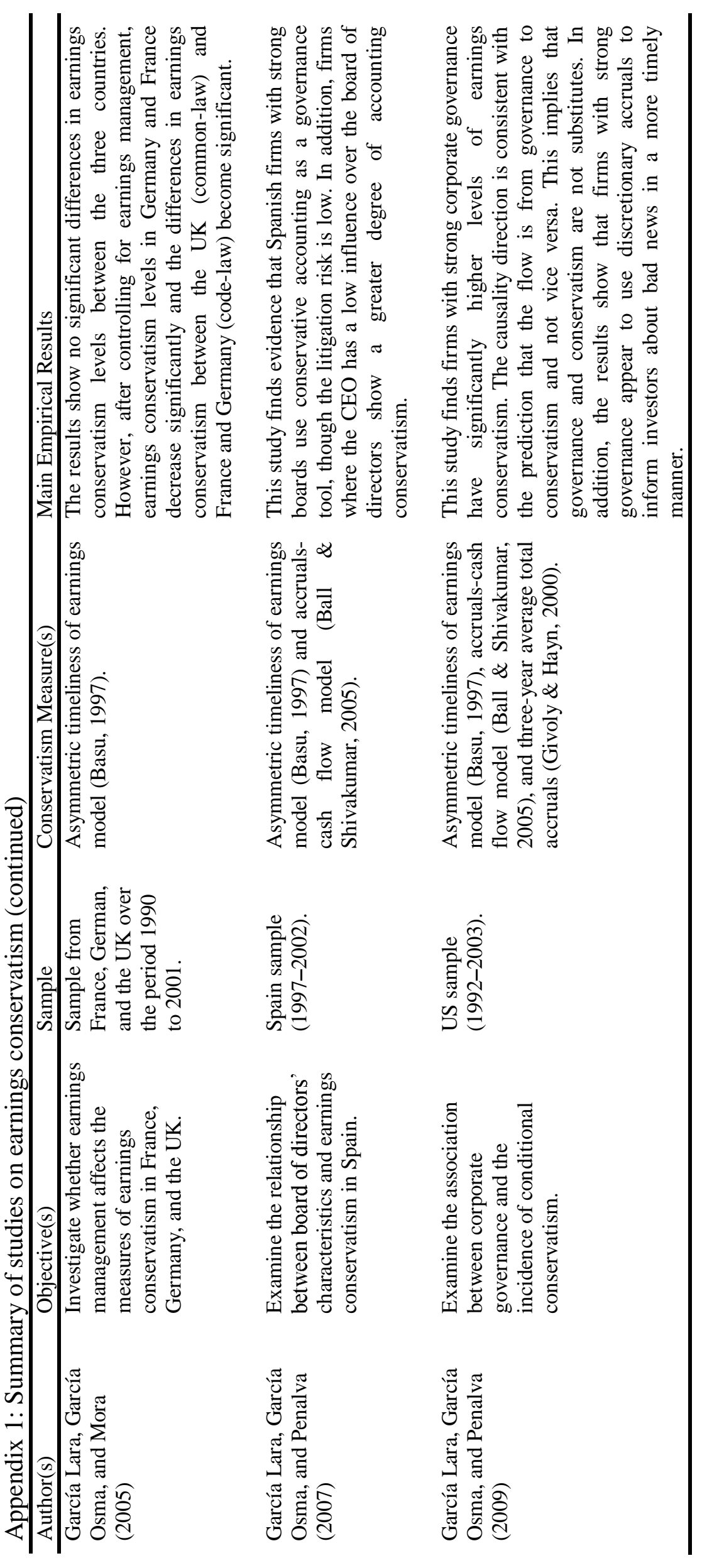

곡 


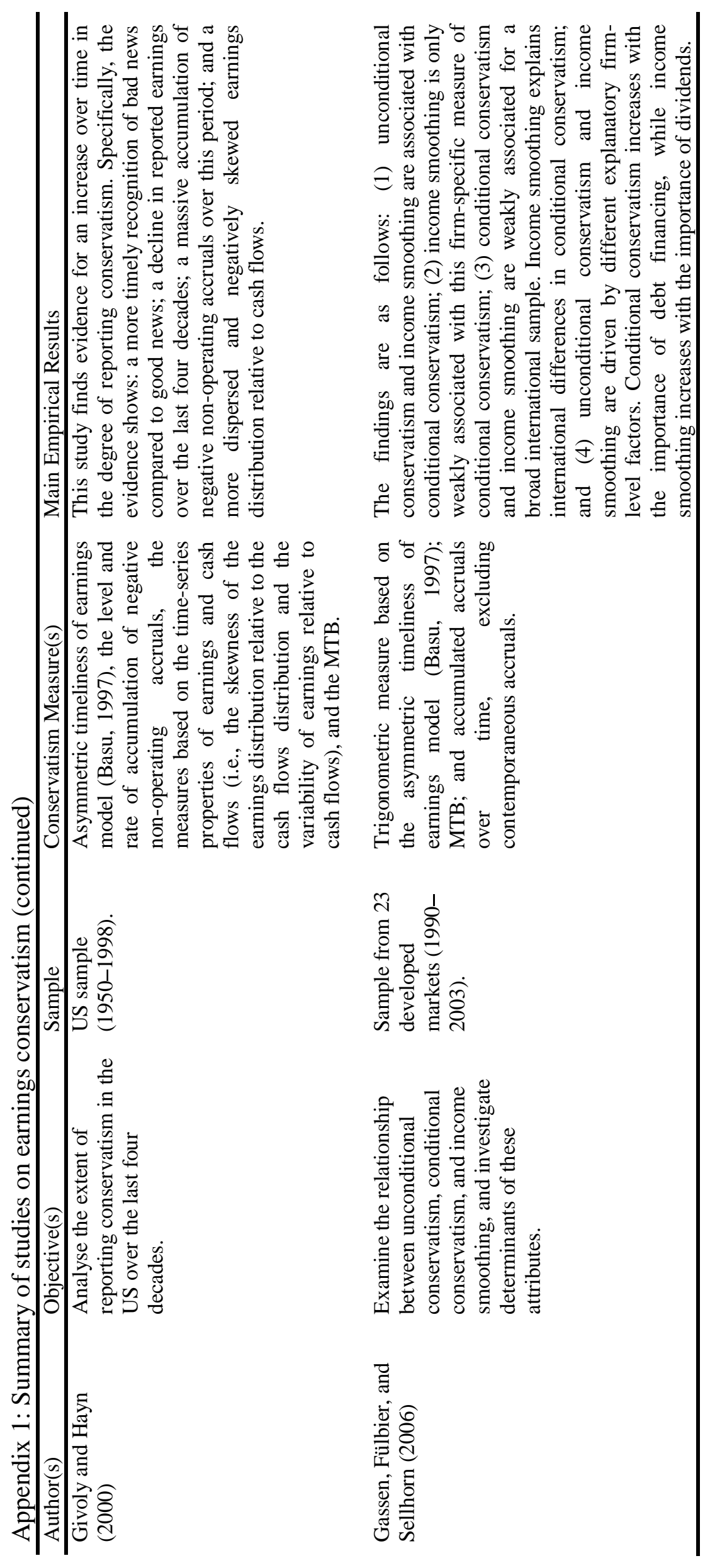

尔 


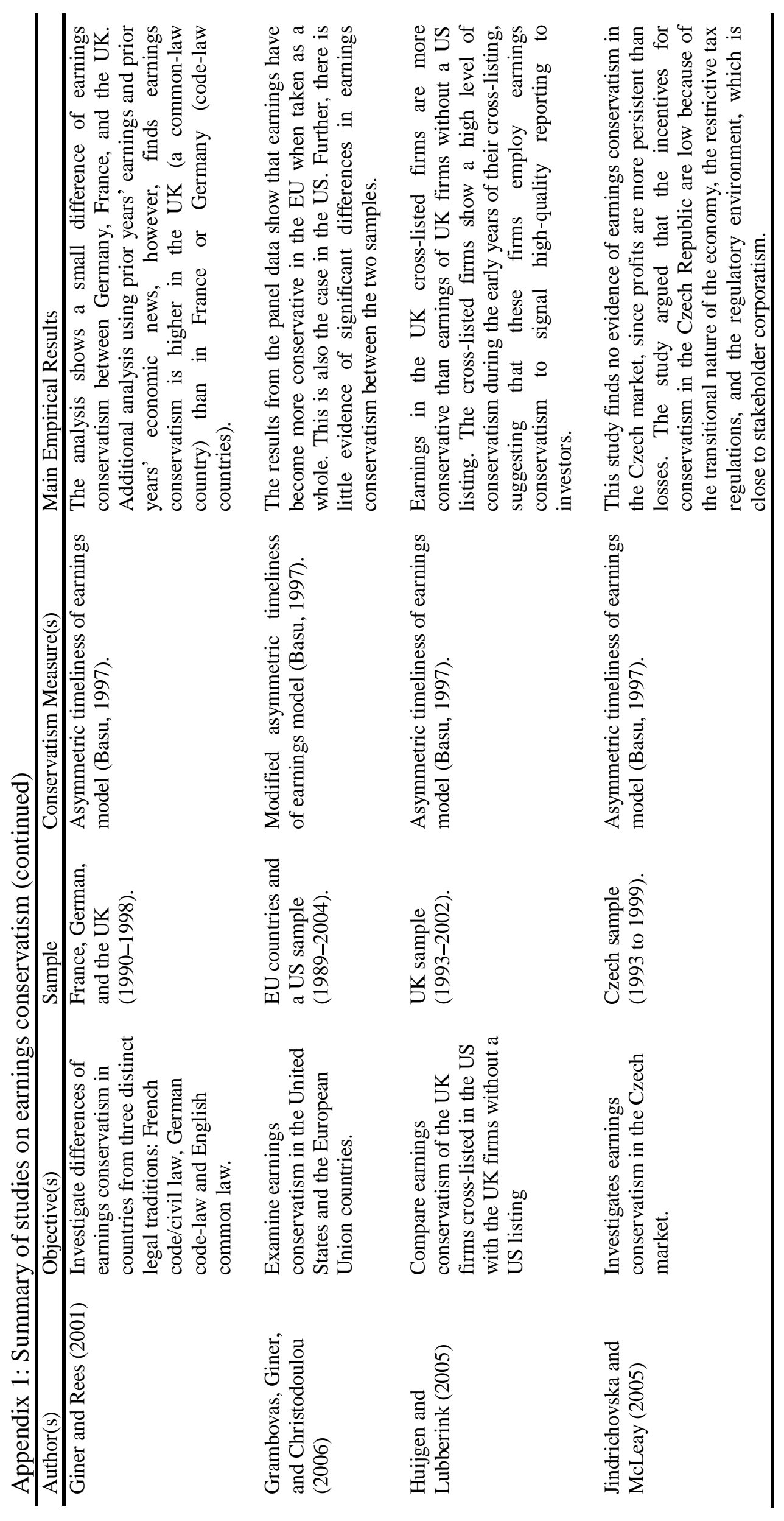

表 


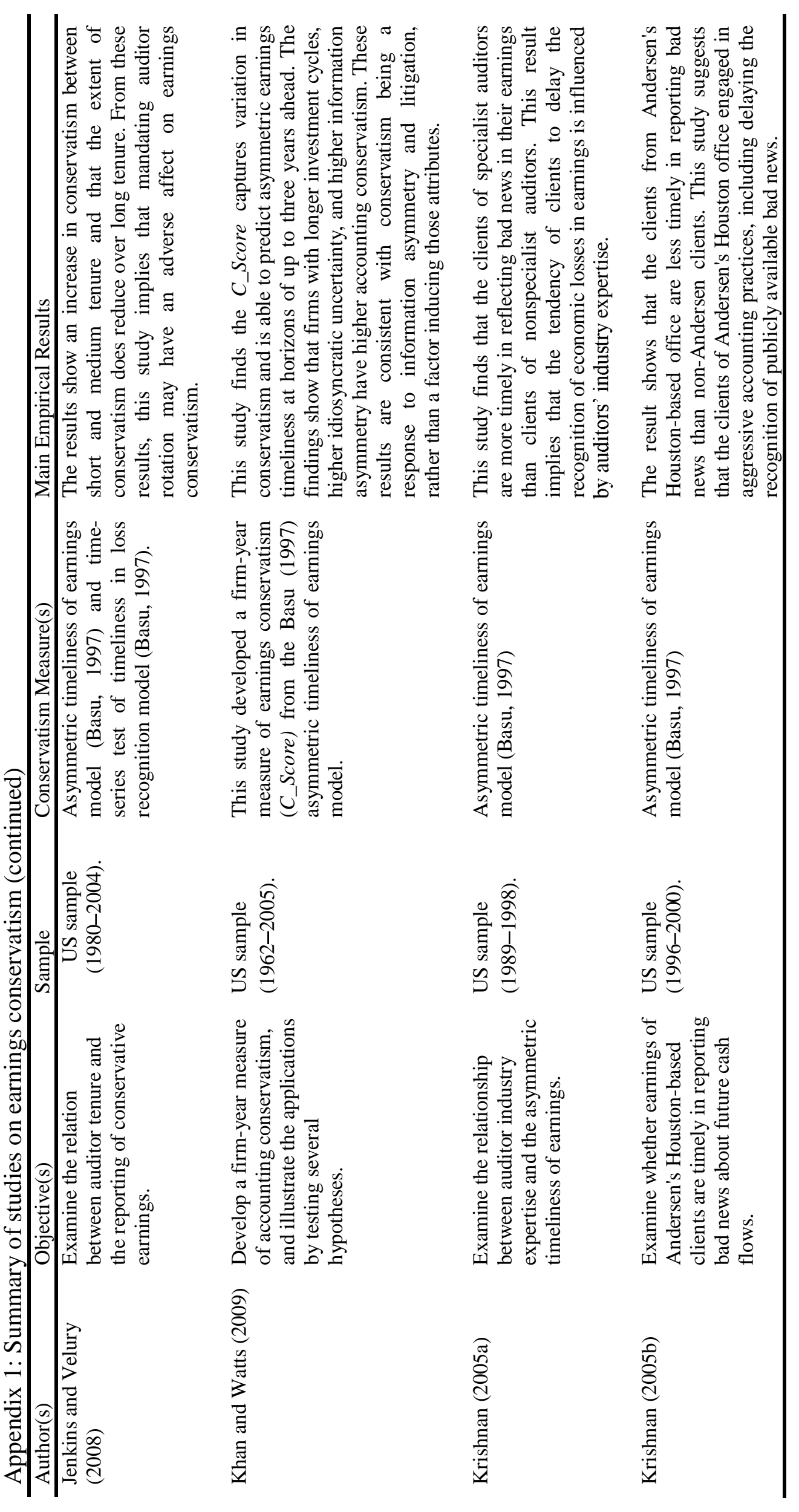

等 


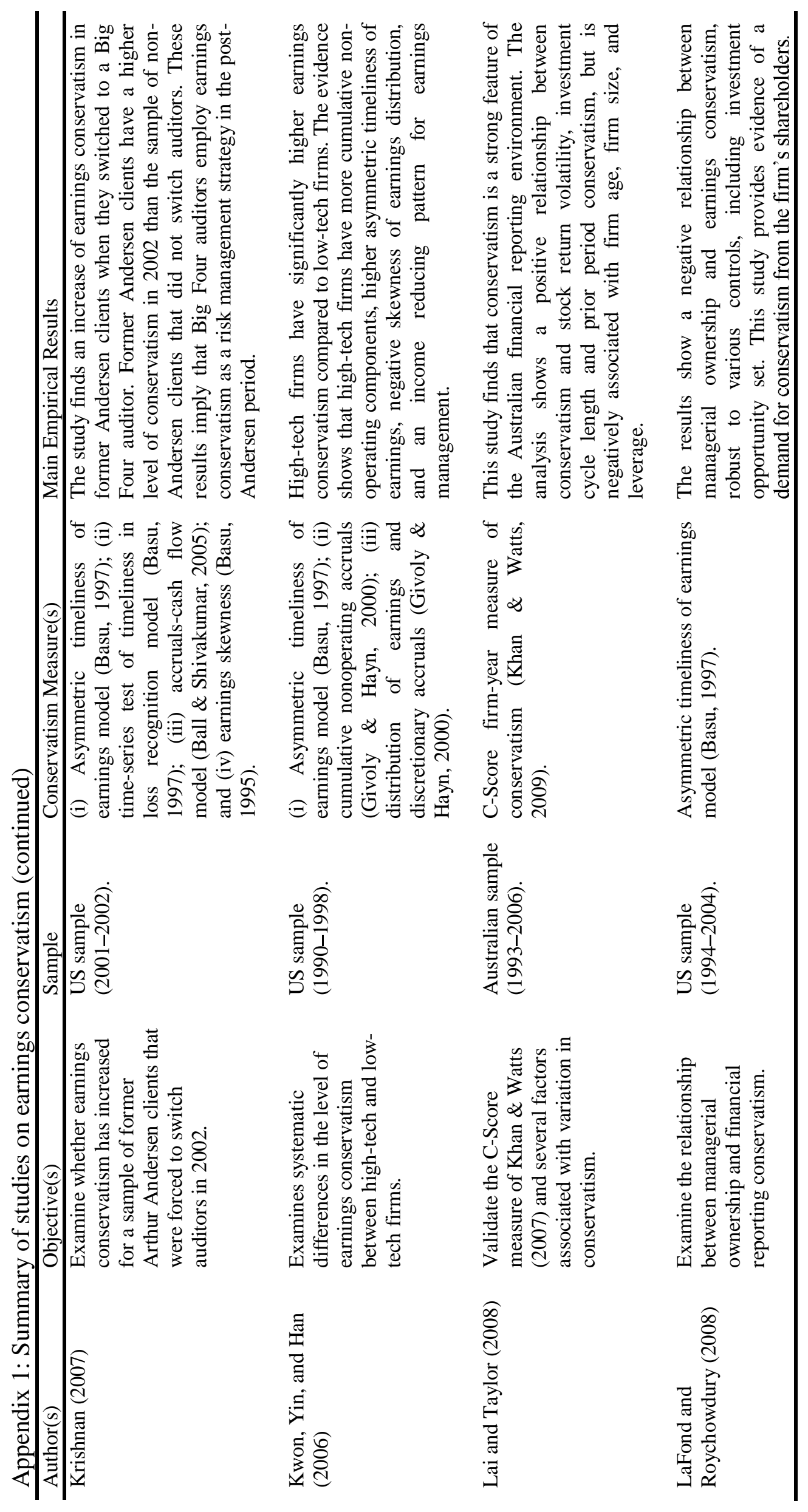

ํํㄴ 


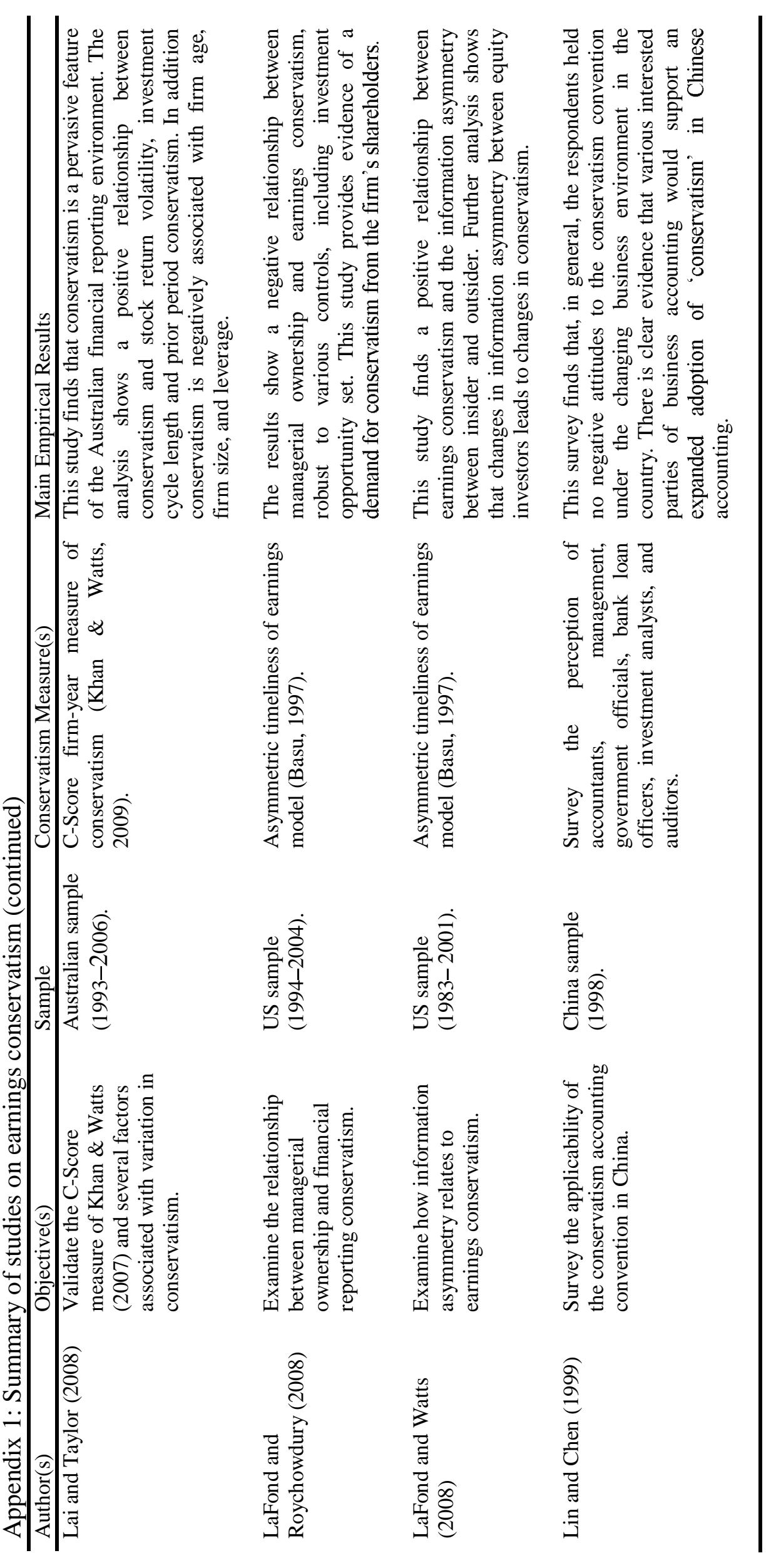

웜 


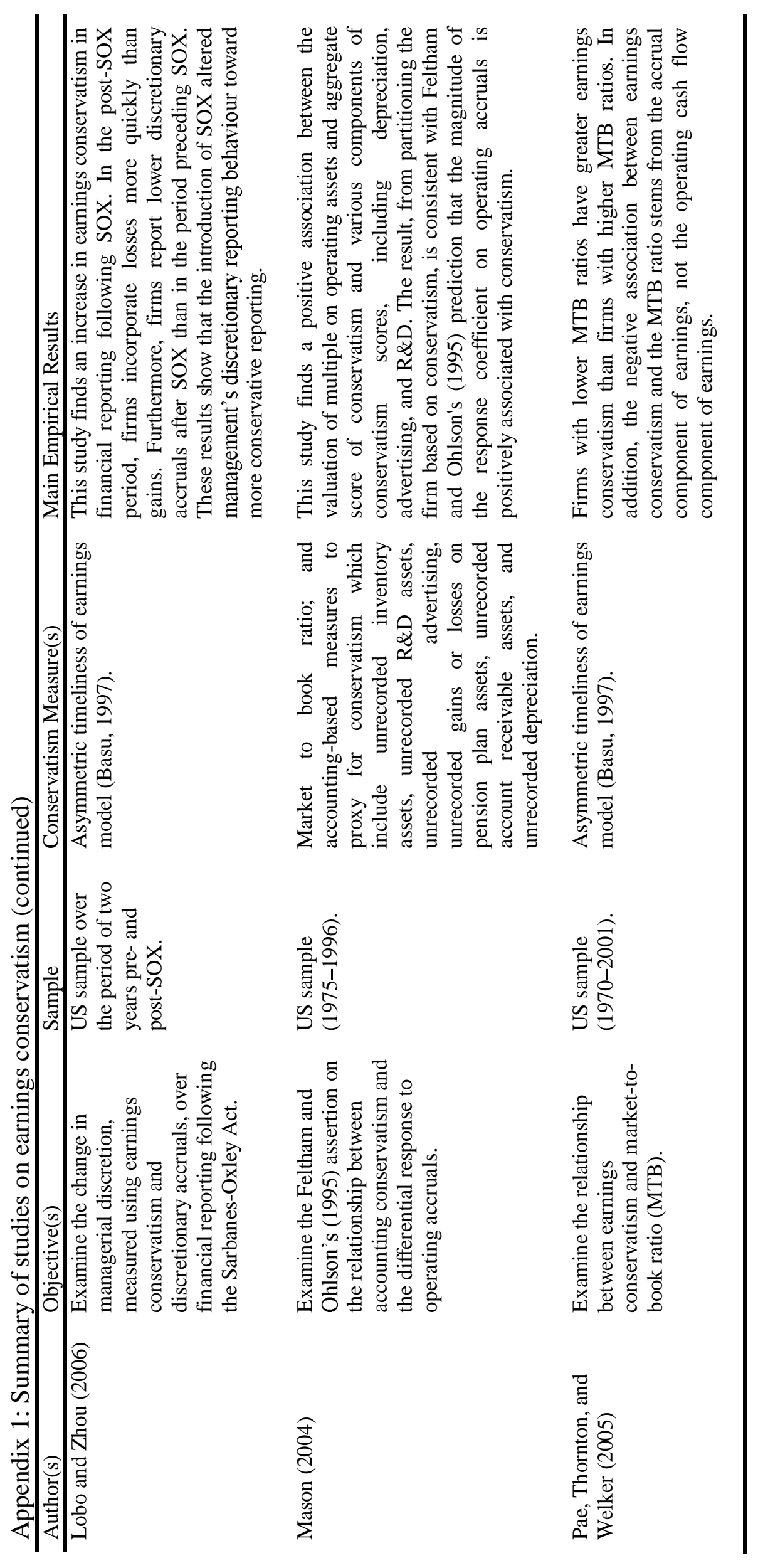

웜 


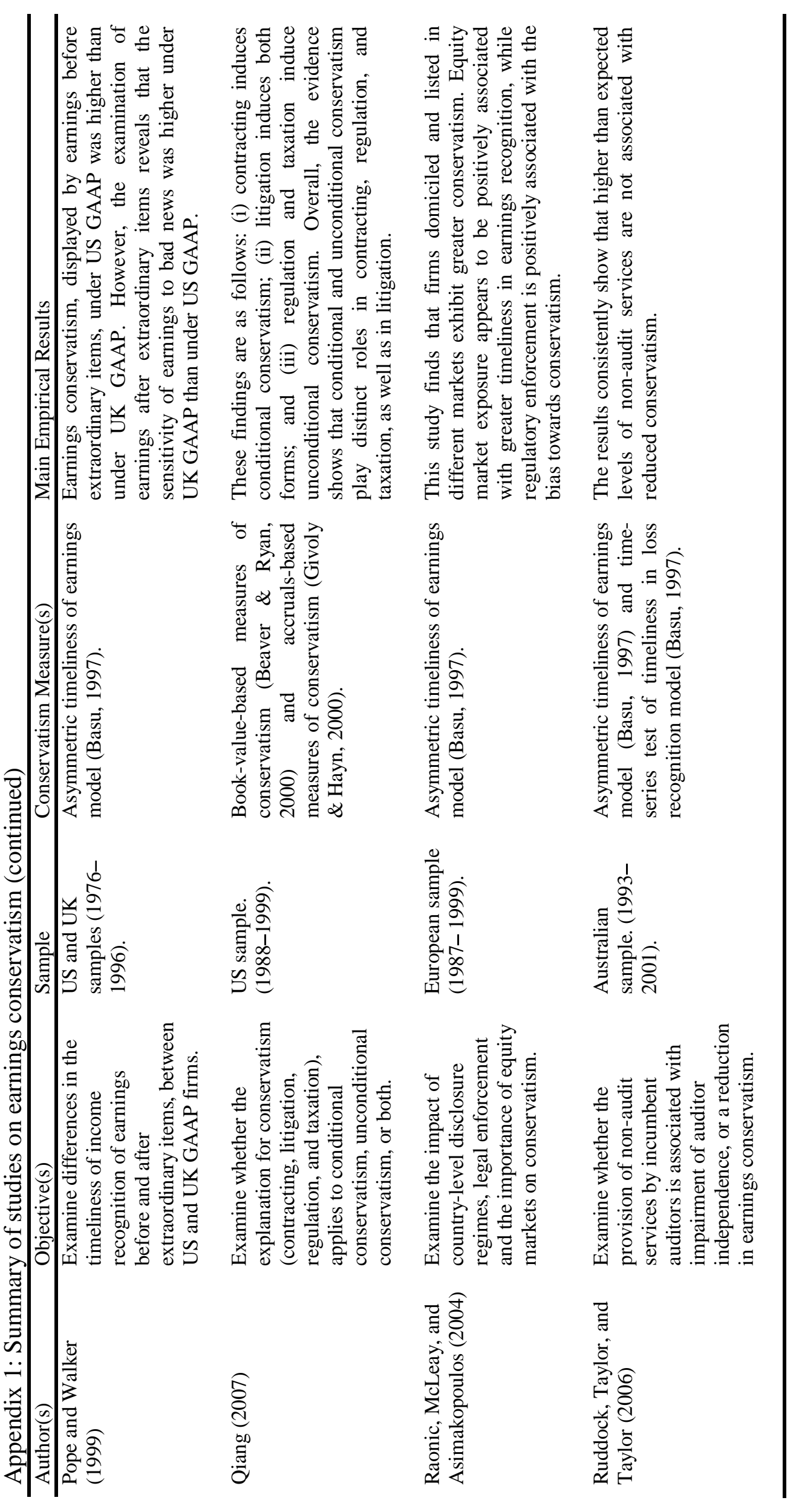

옥 


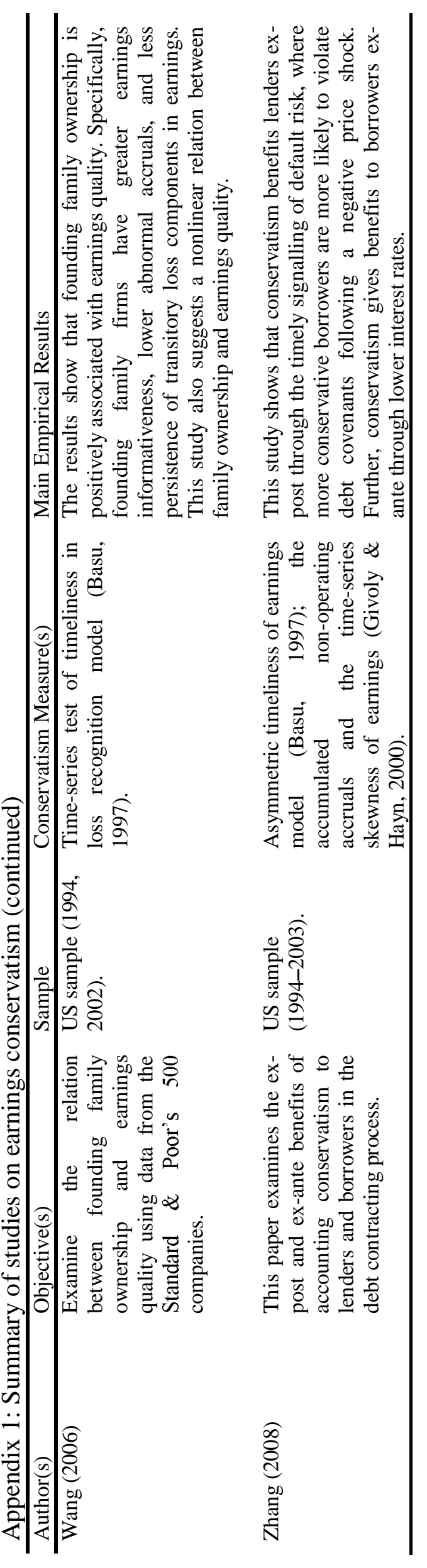

욤 


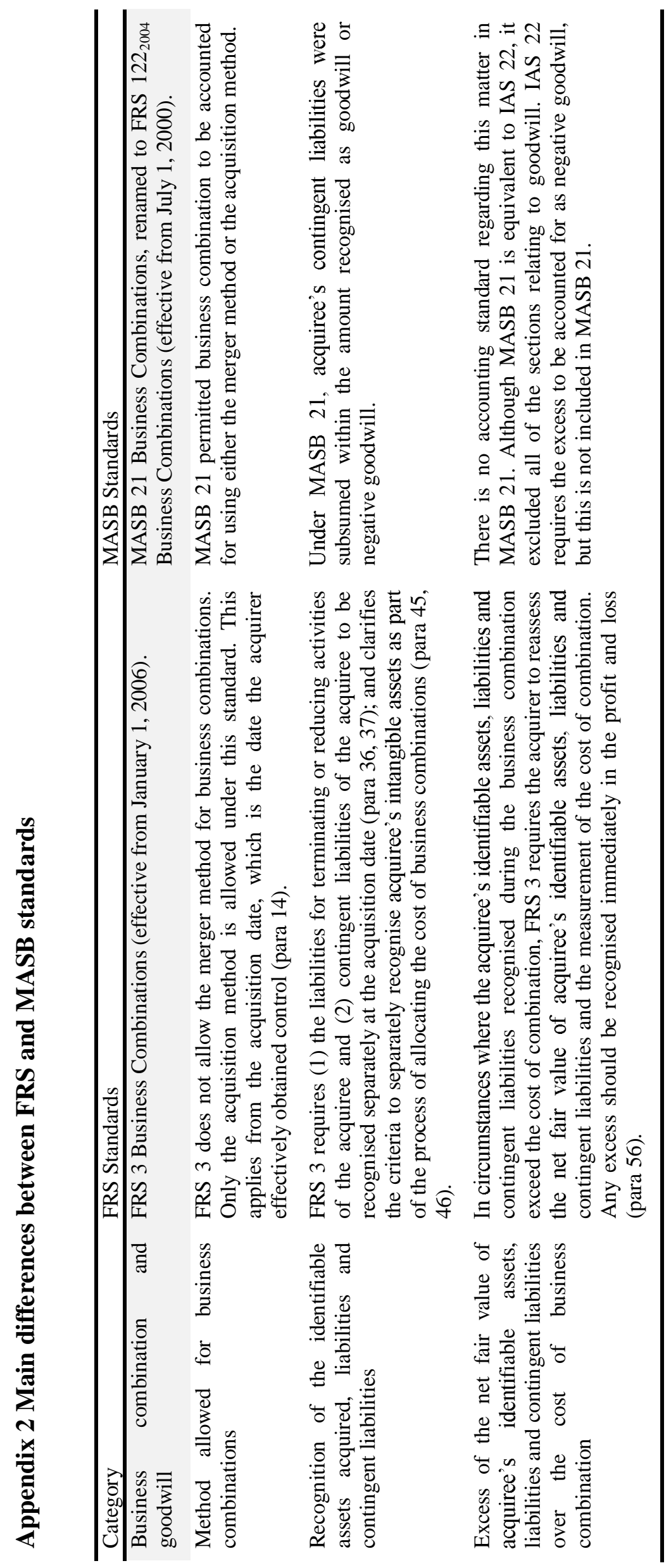

$\sqrt{3}$ 


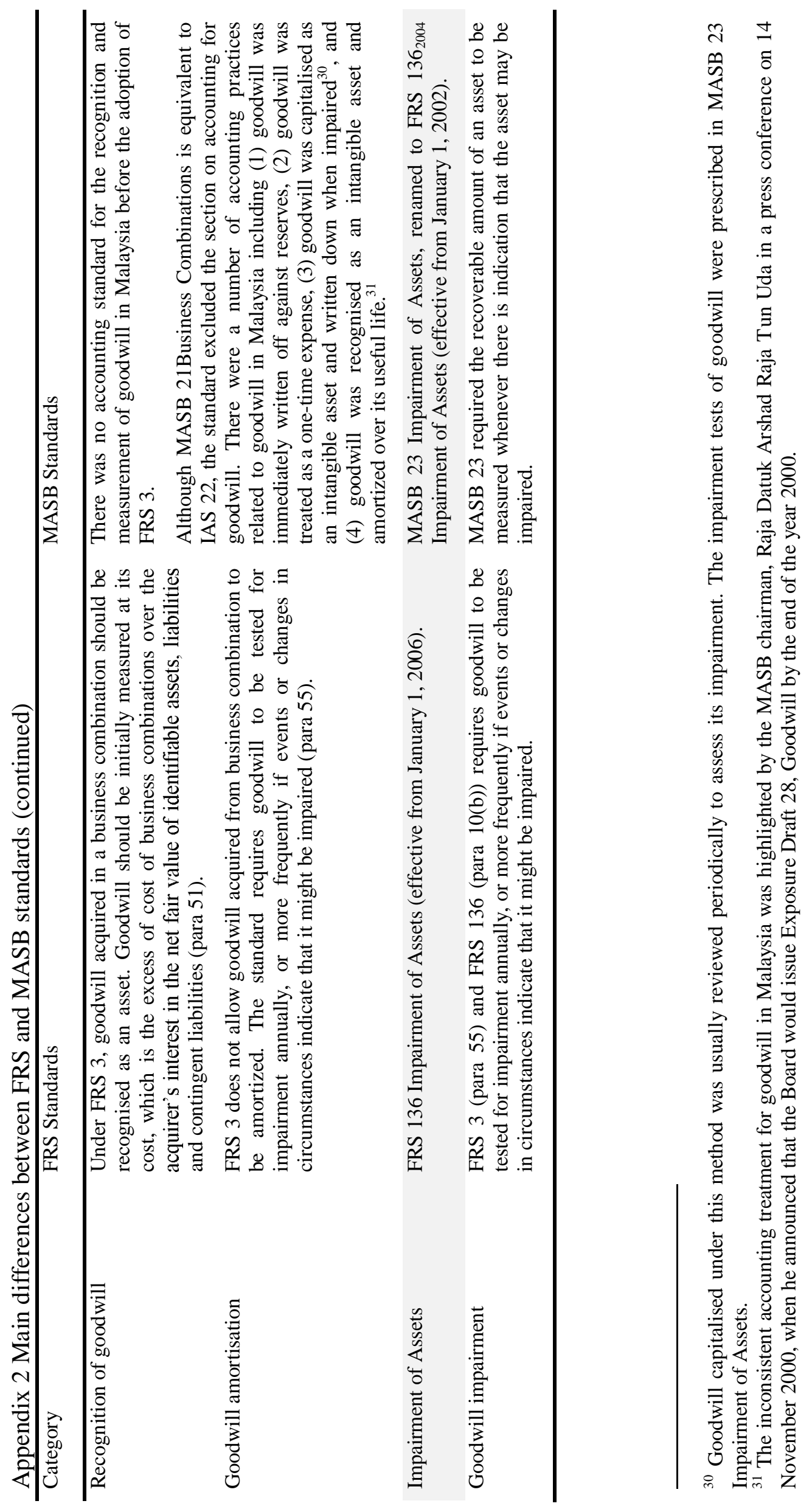




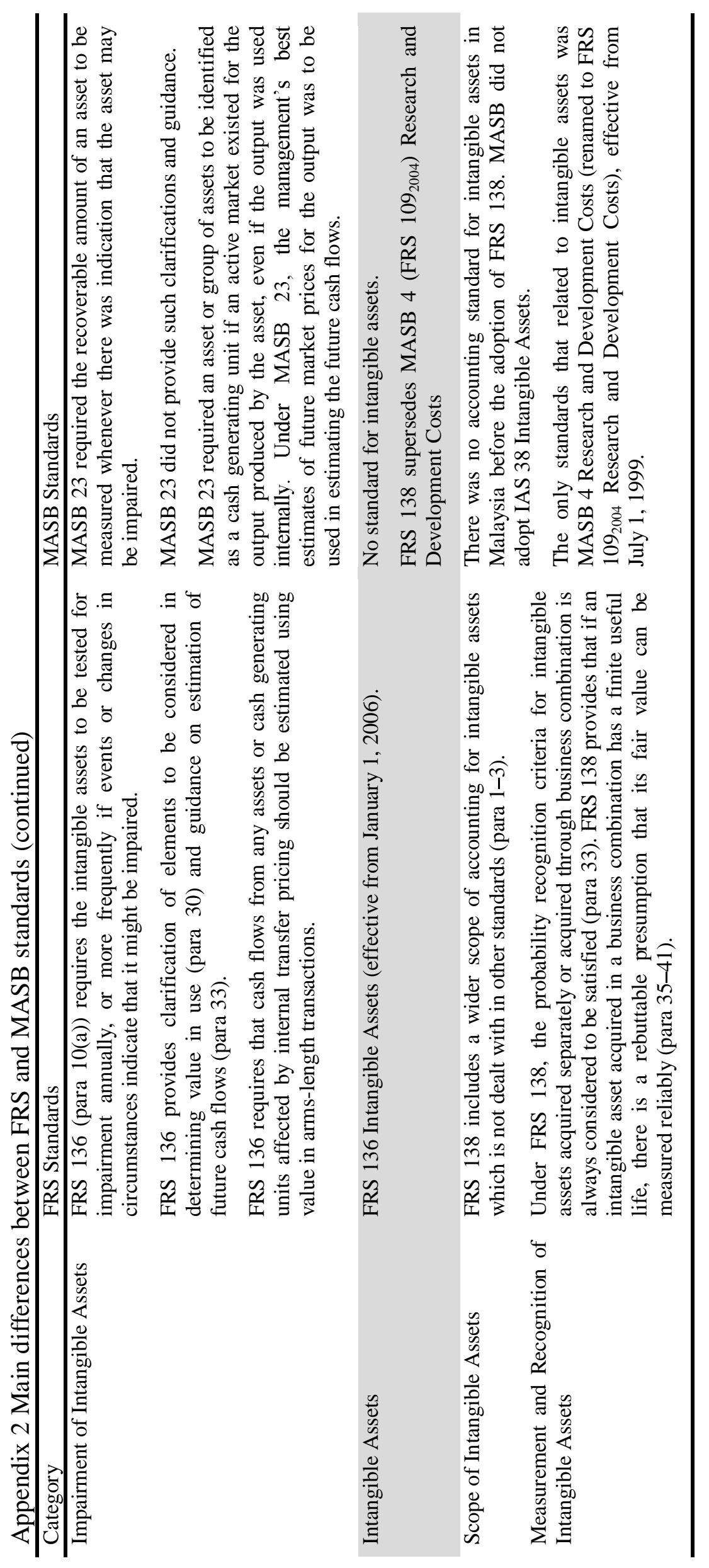




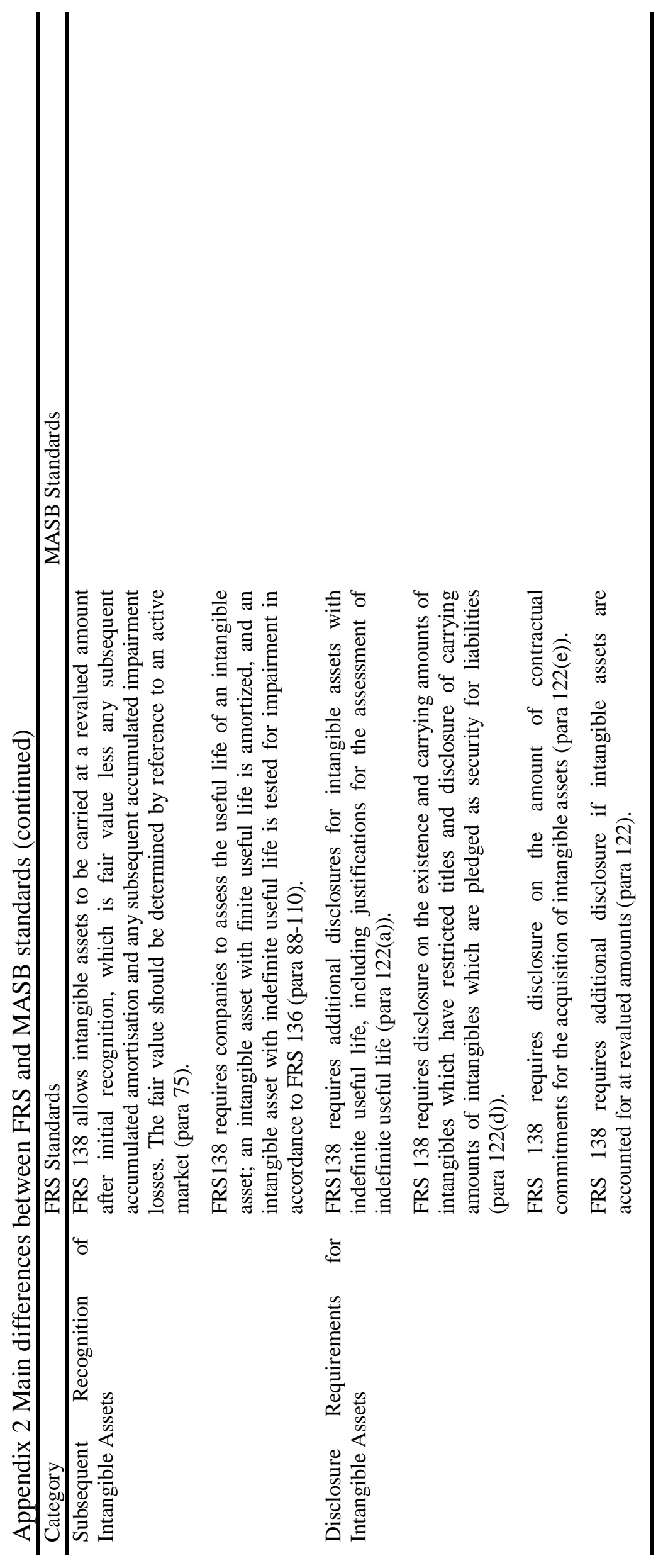




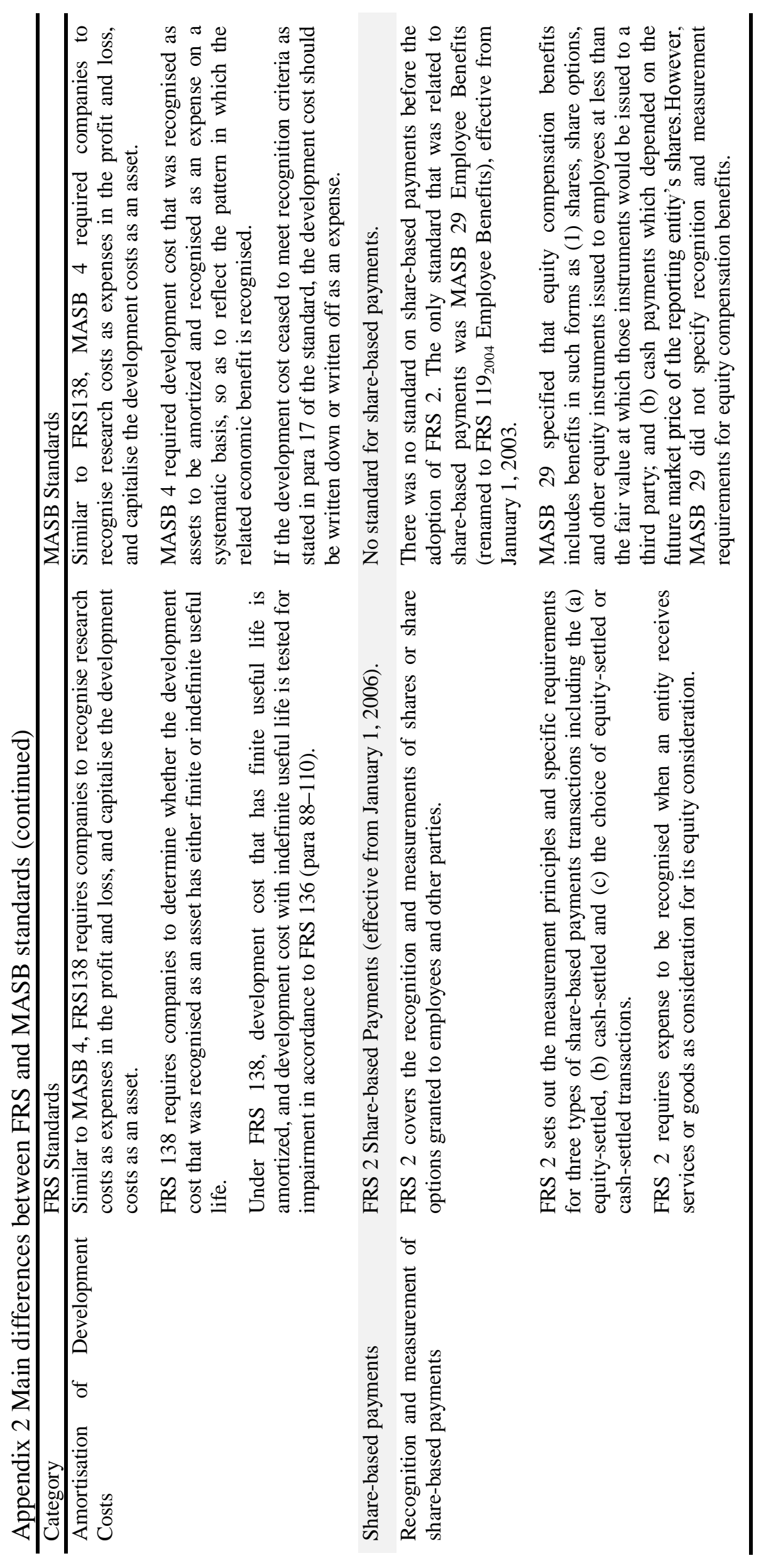




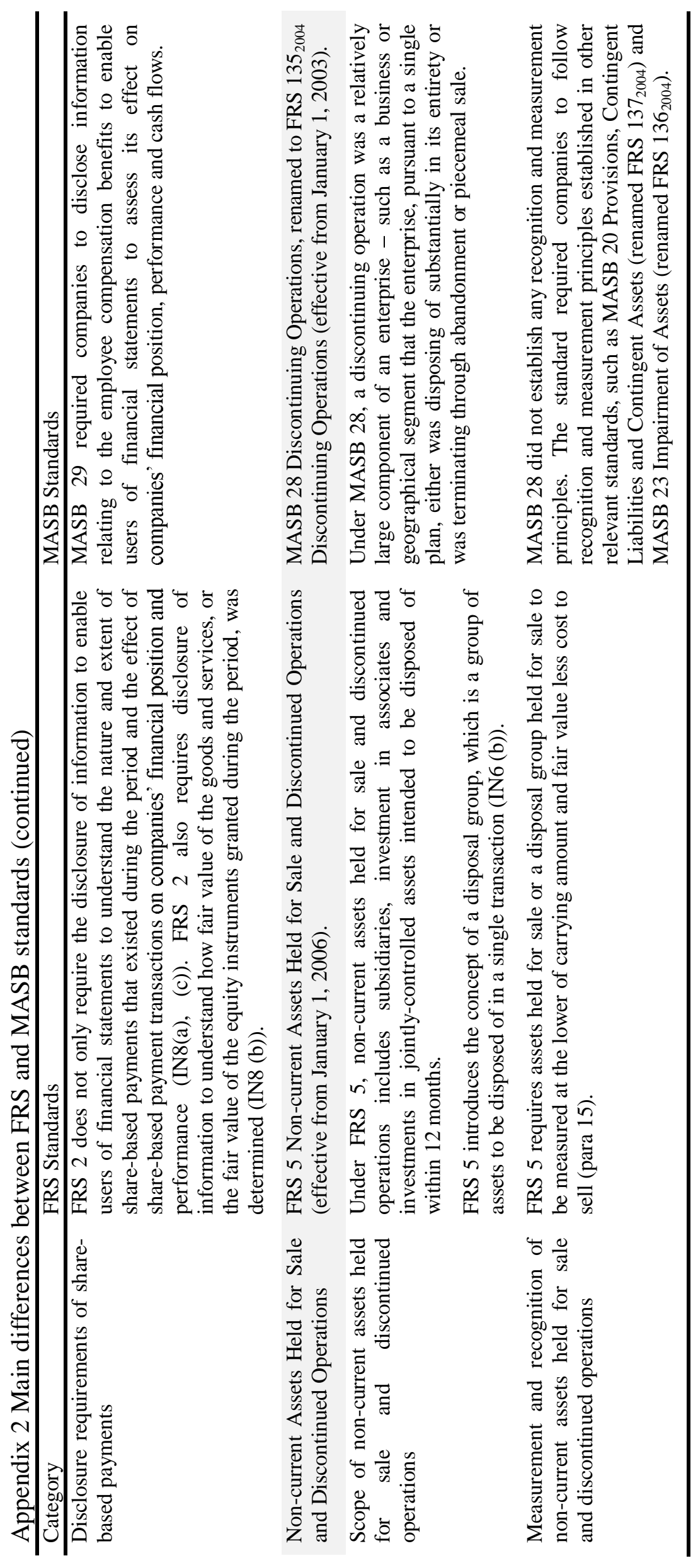

i̊ 


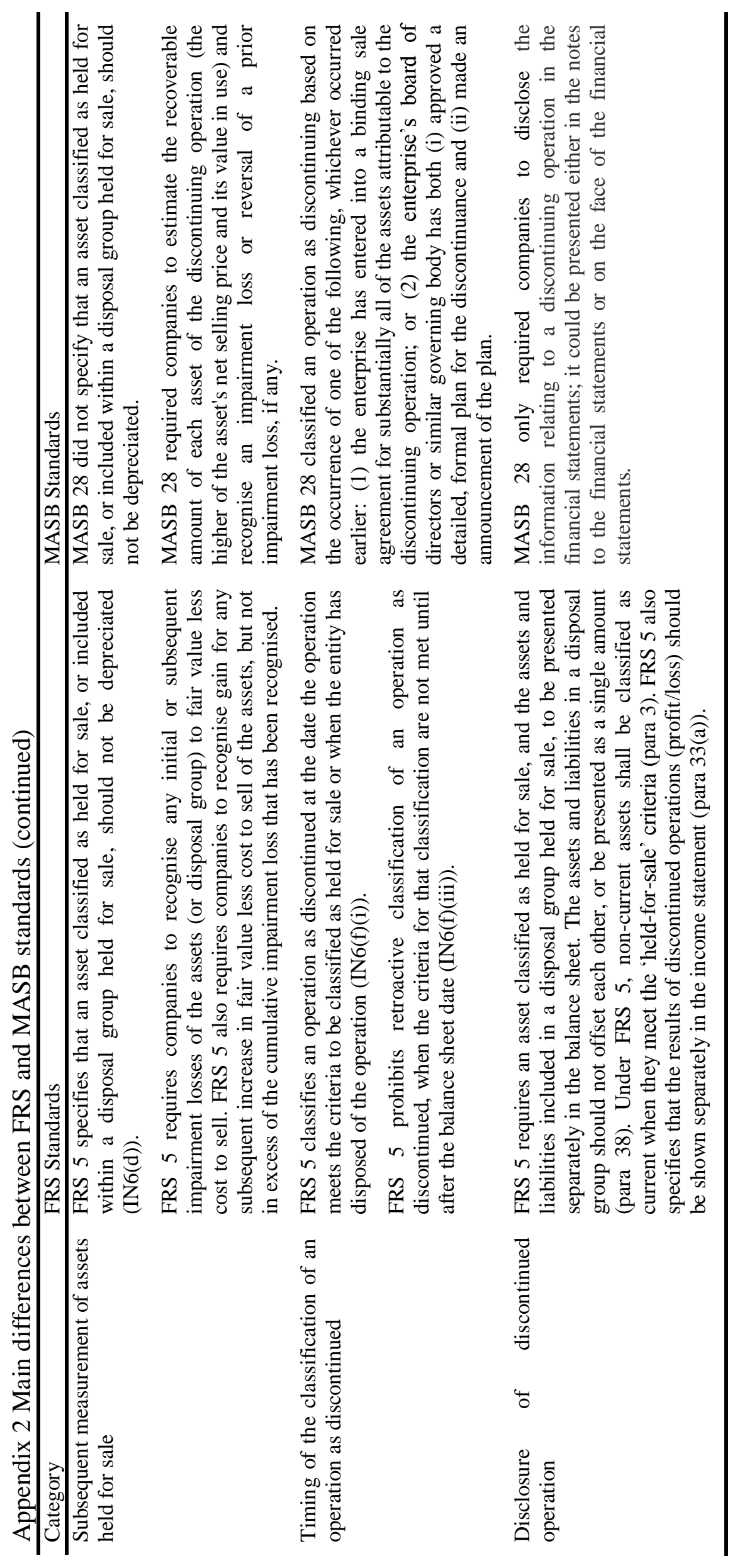

5 


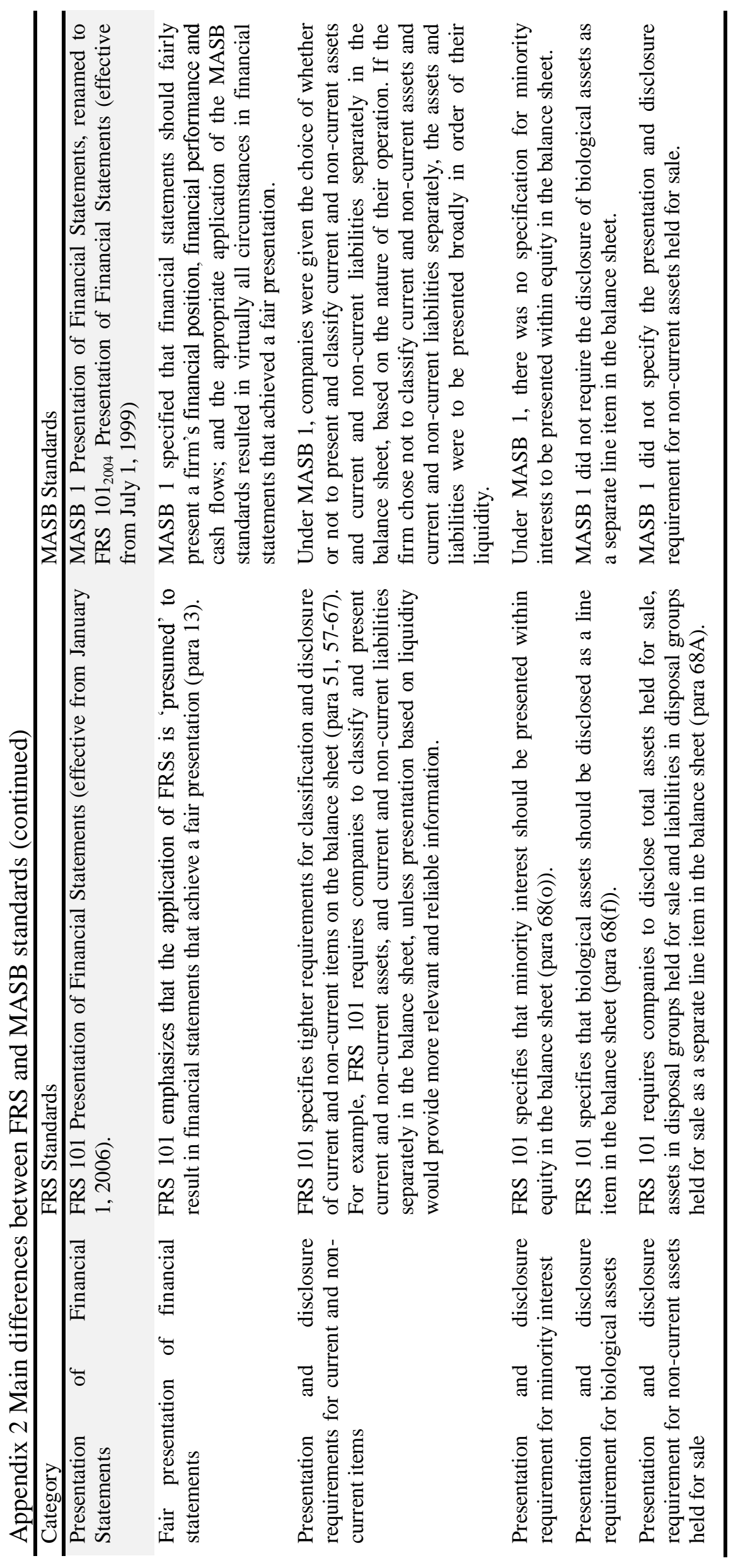

$\stackrel{\infty}{2}$ 


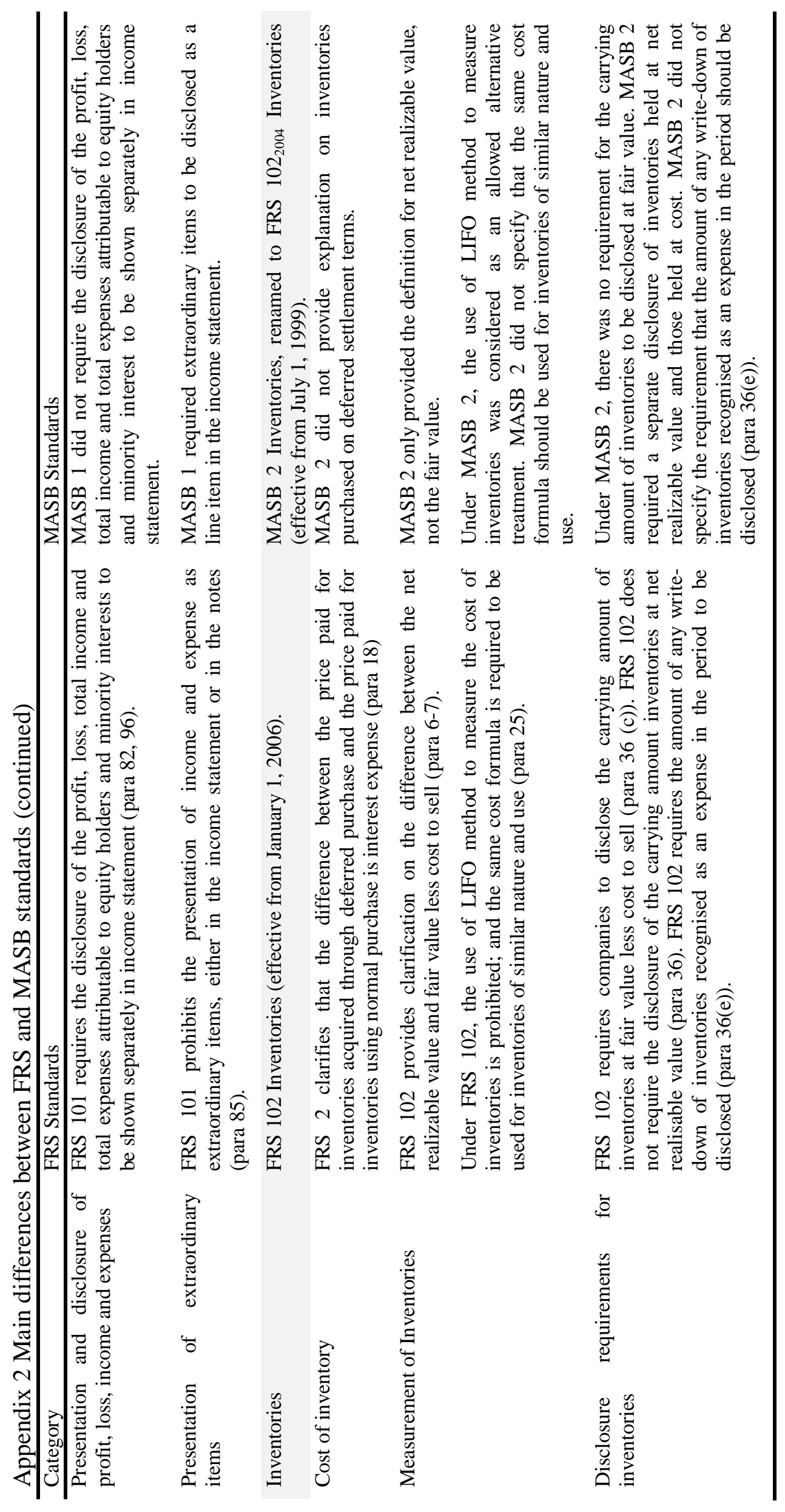

ते 


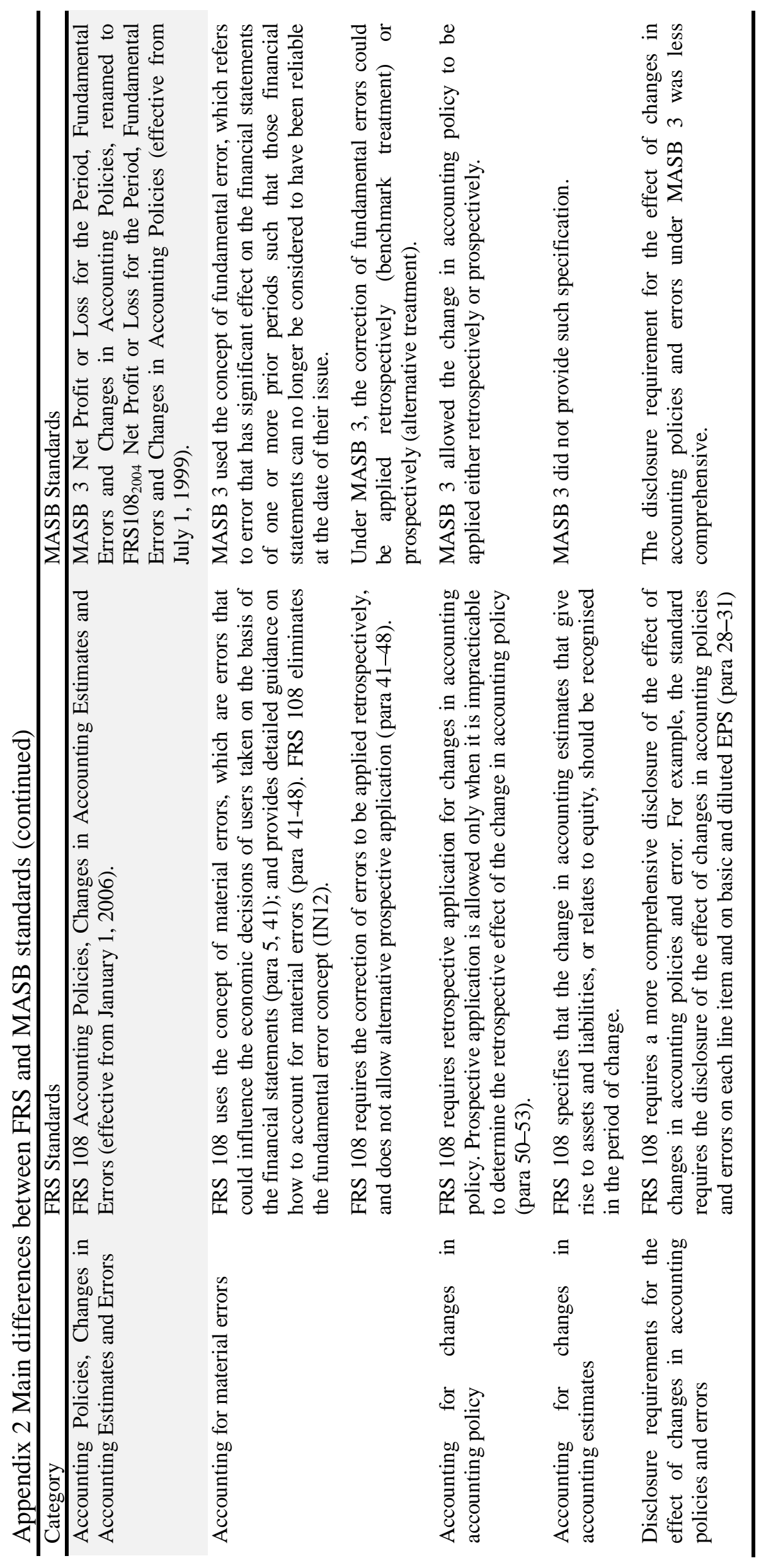

8 


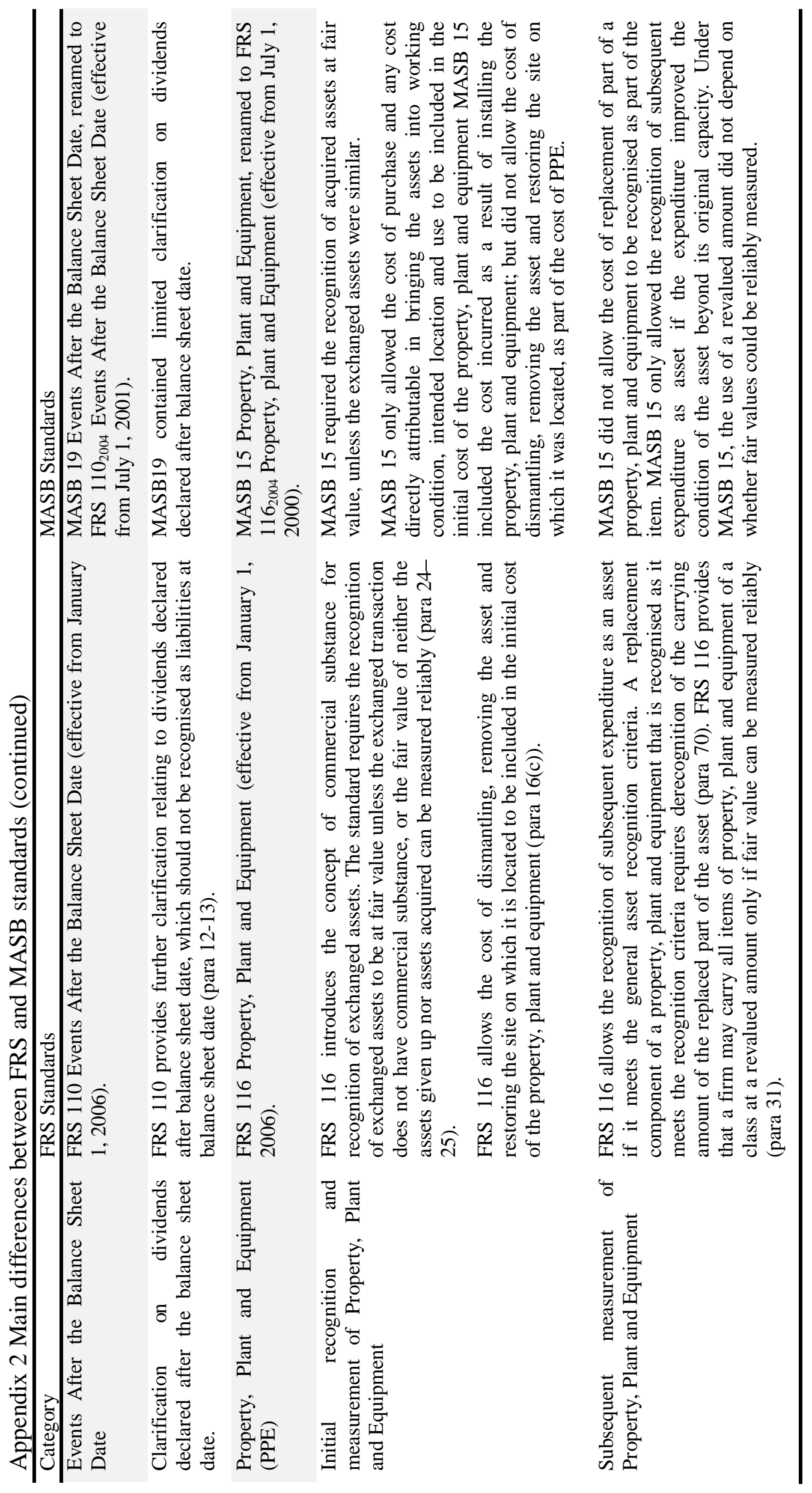

ర్ 


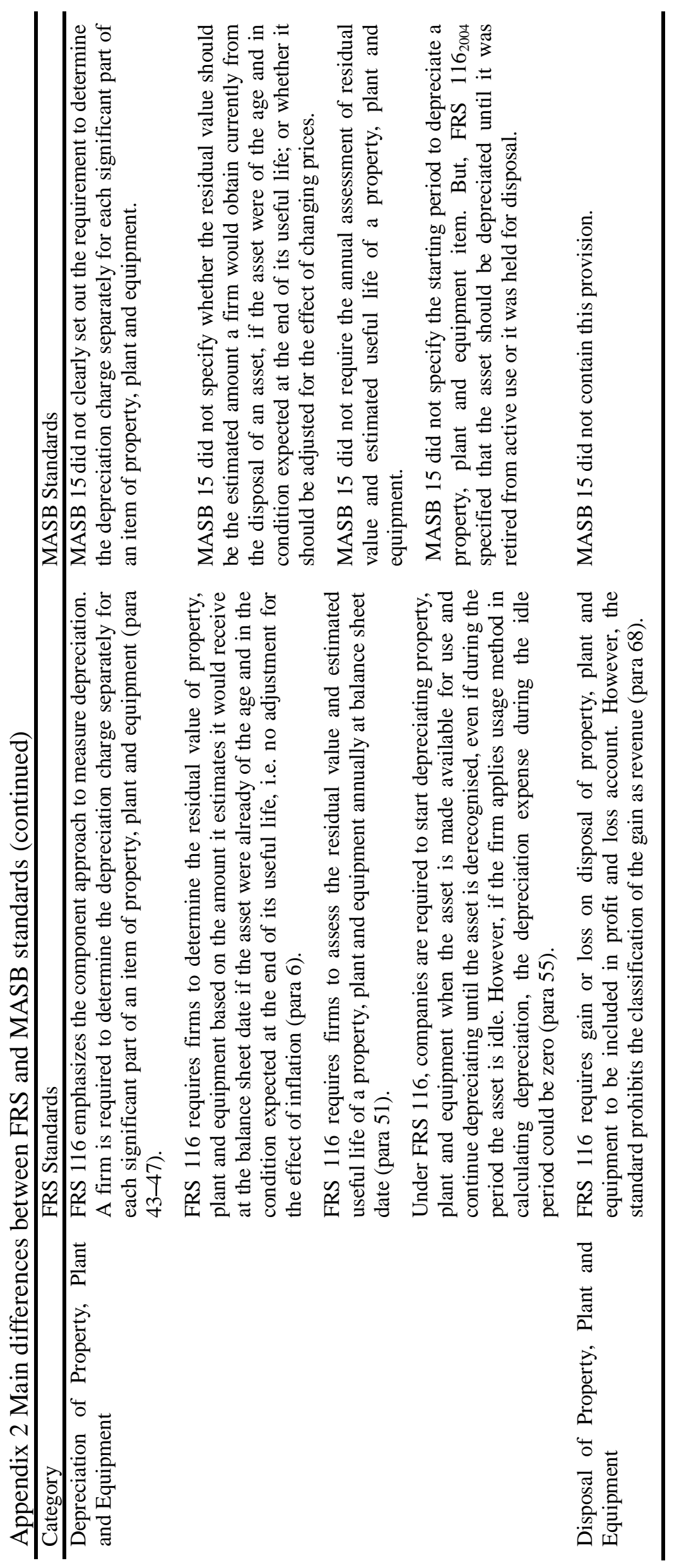

임 


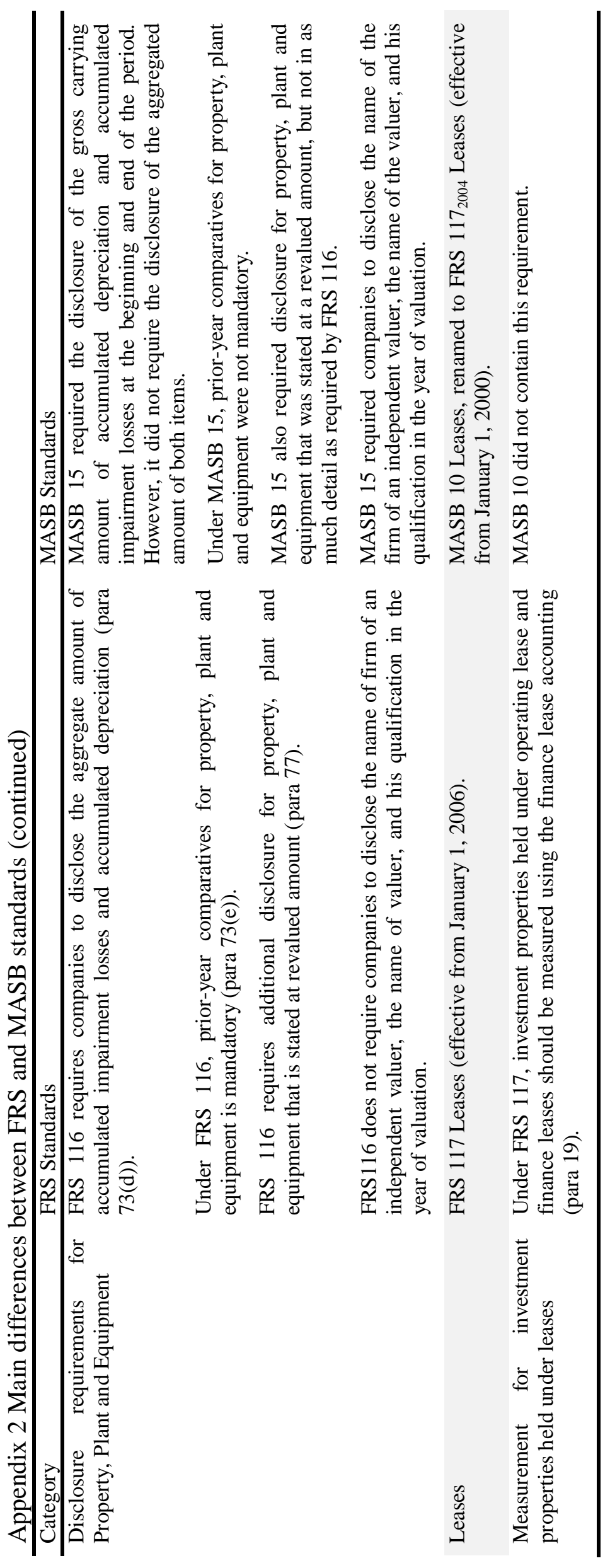




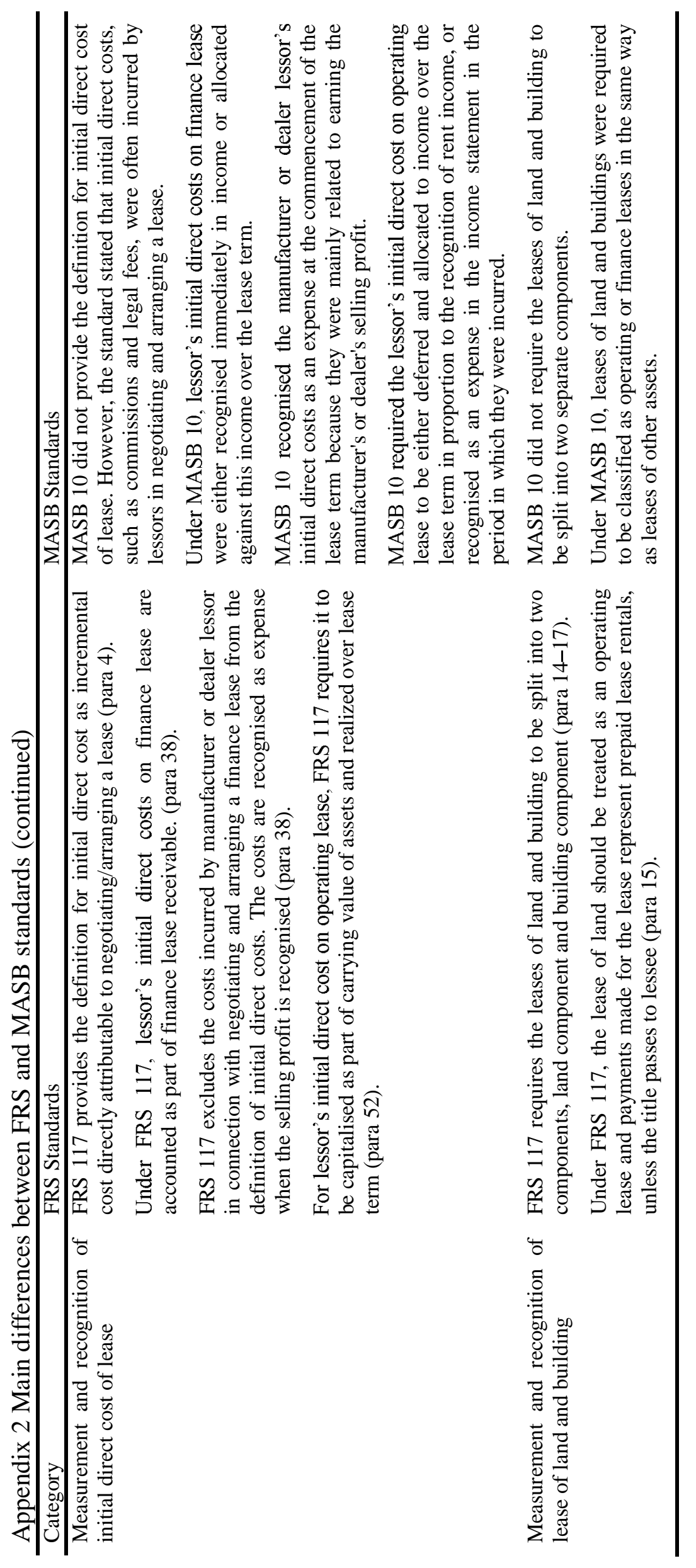




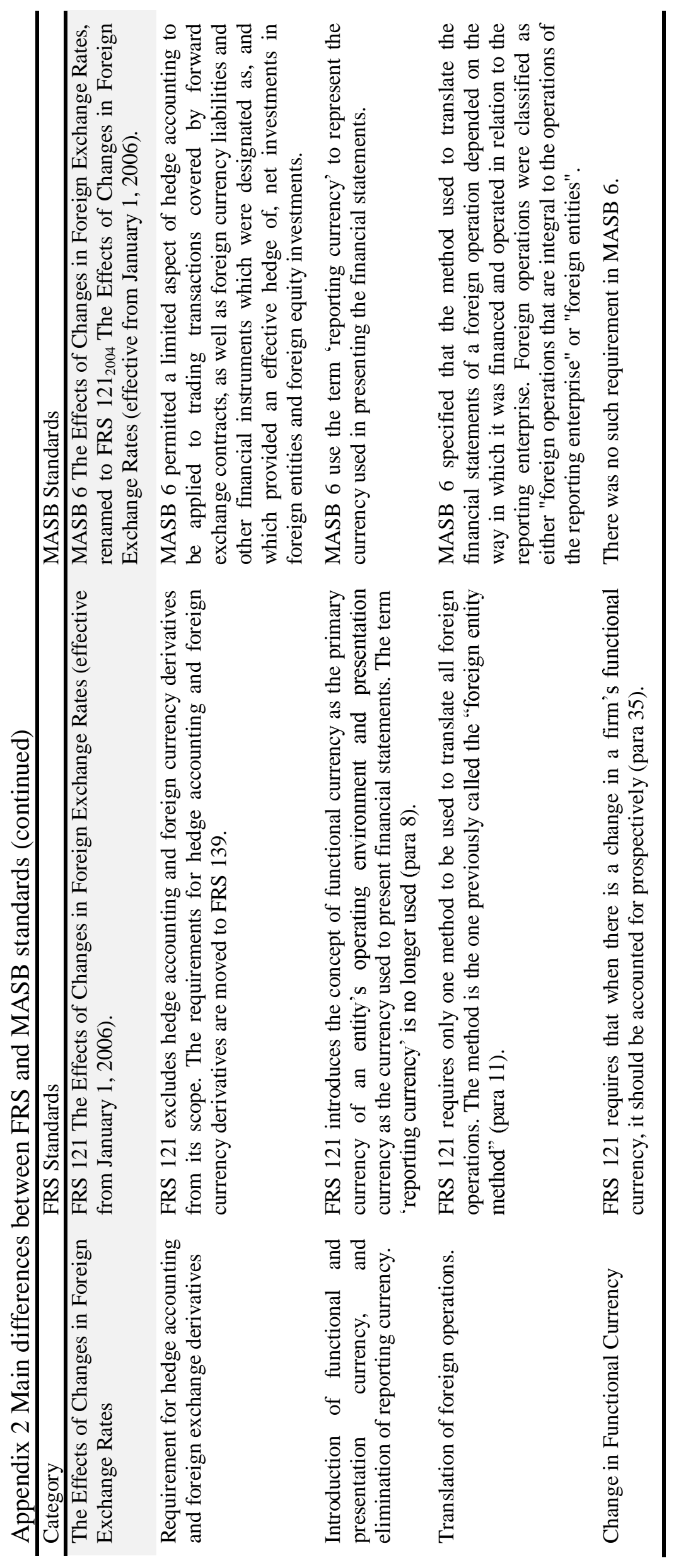

: 


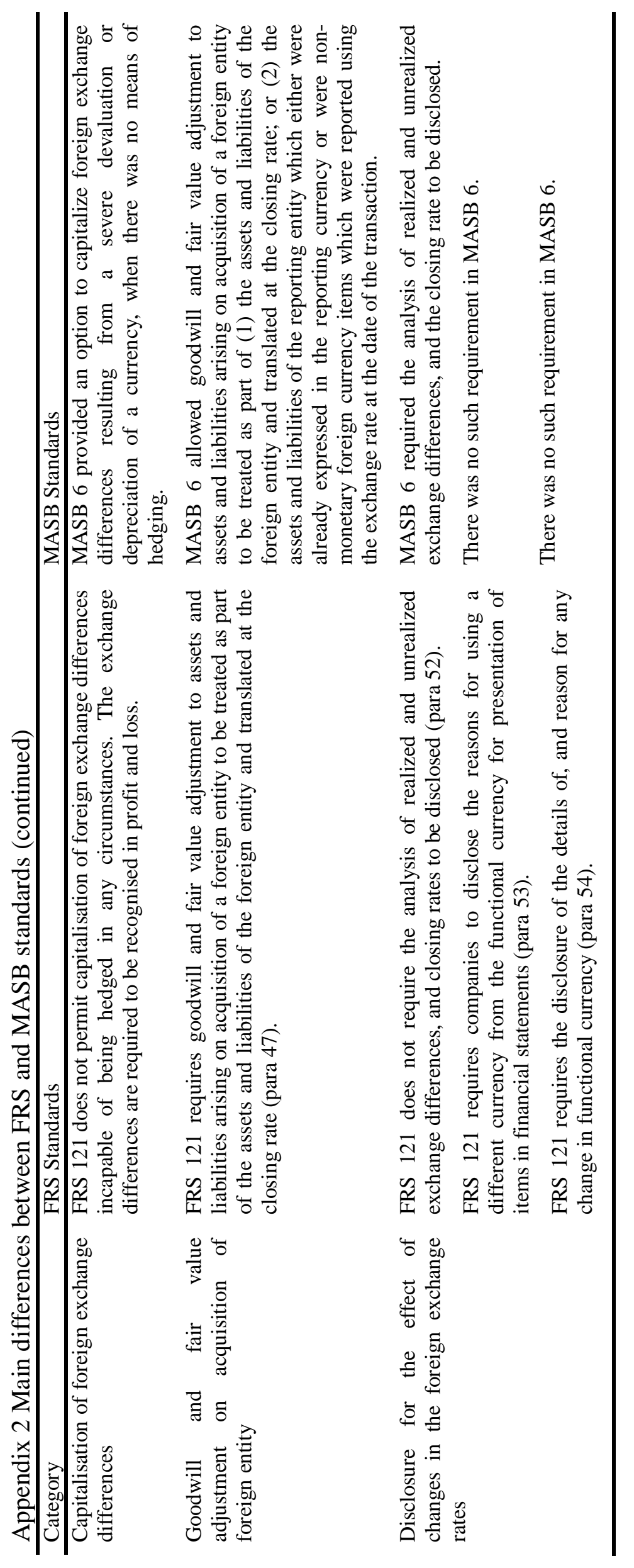

ํํํ 


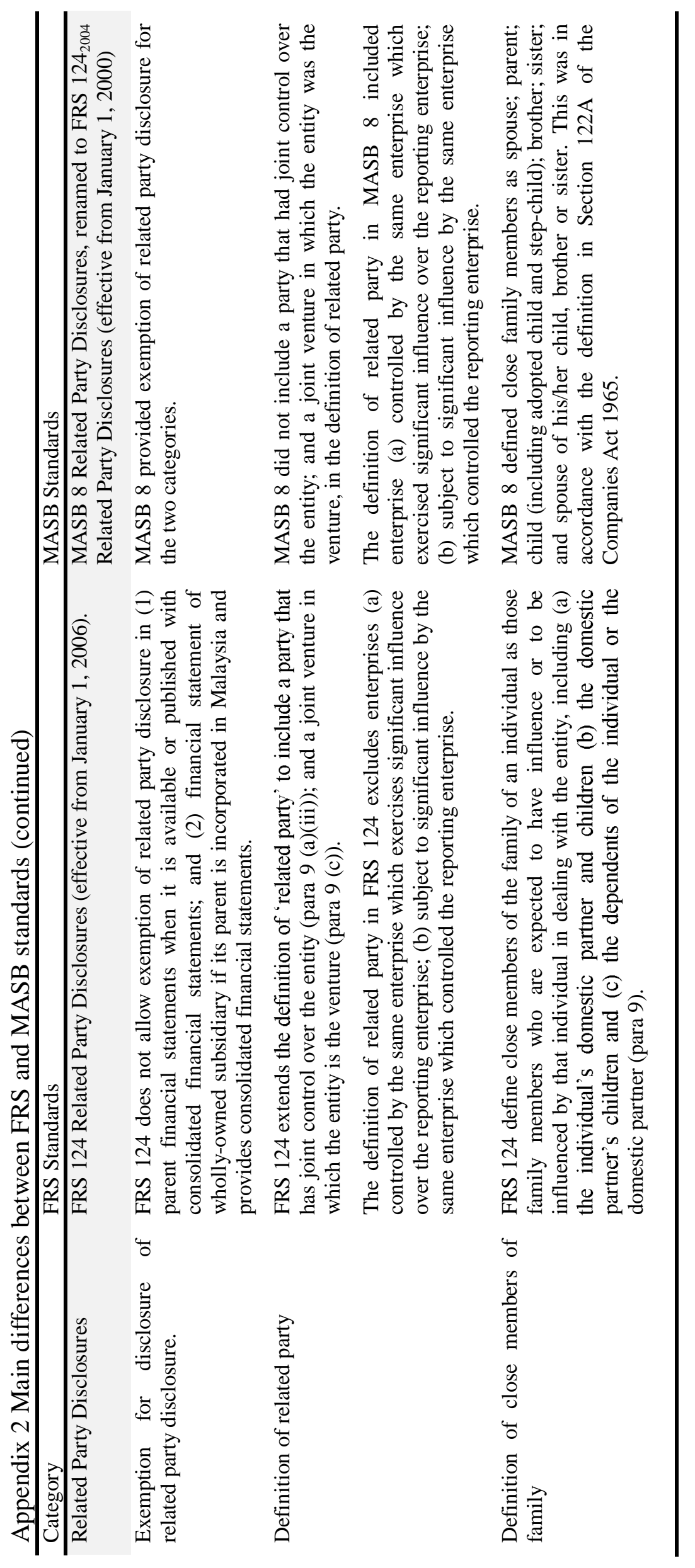




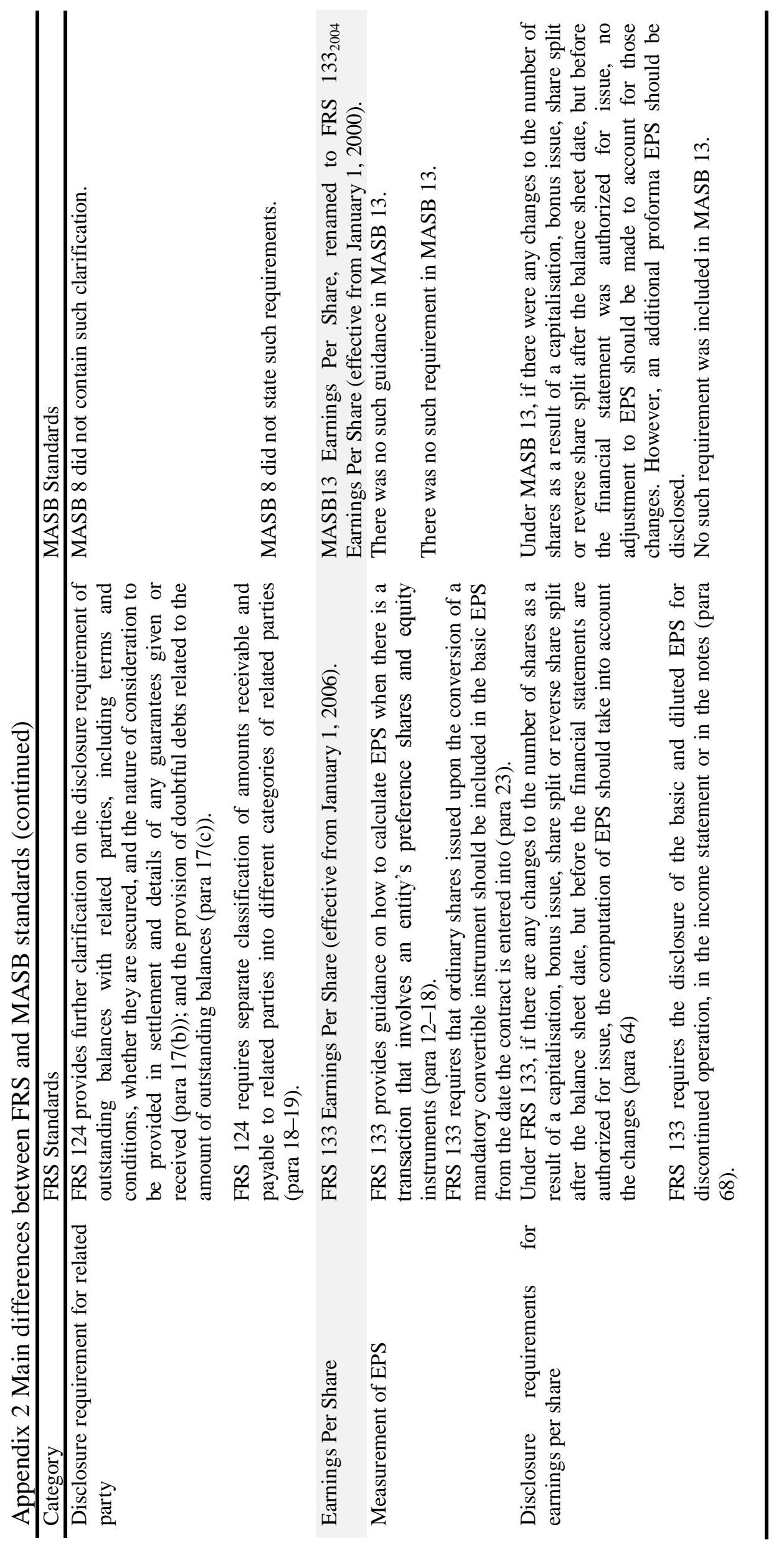

잉 


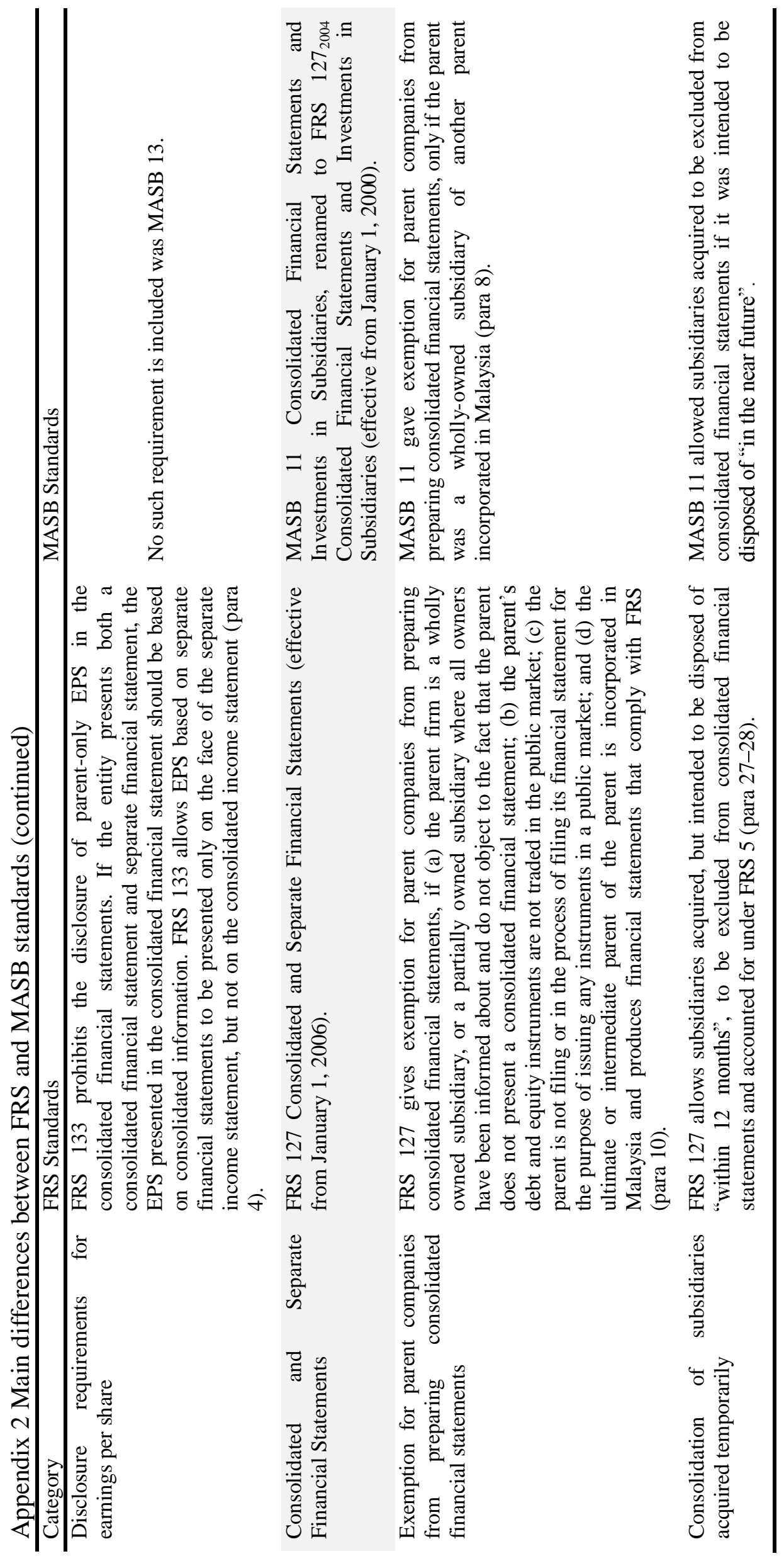

요 


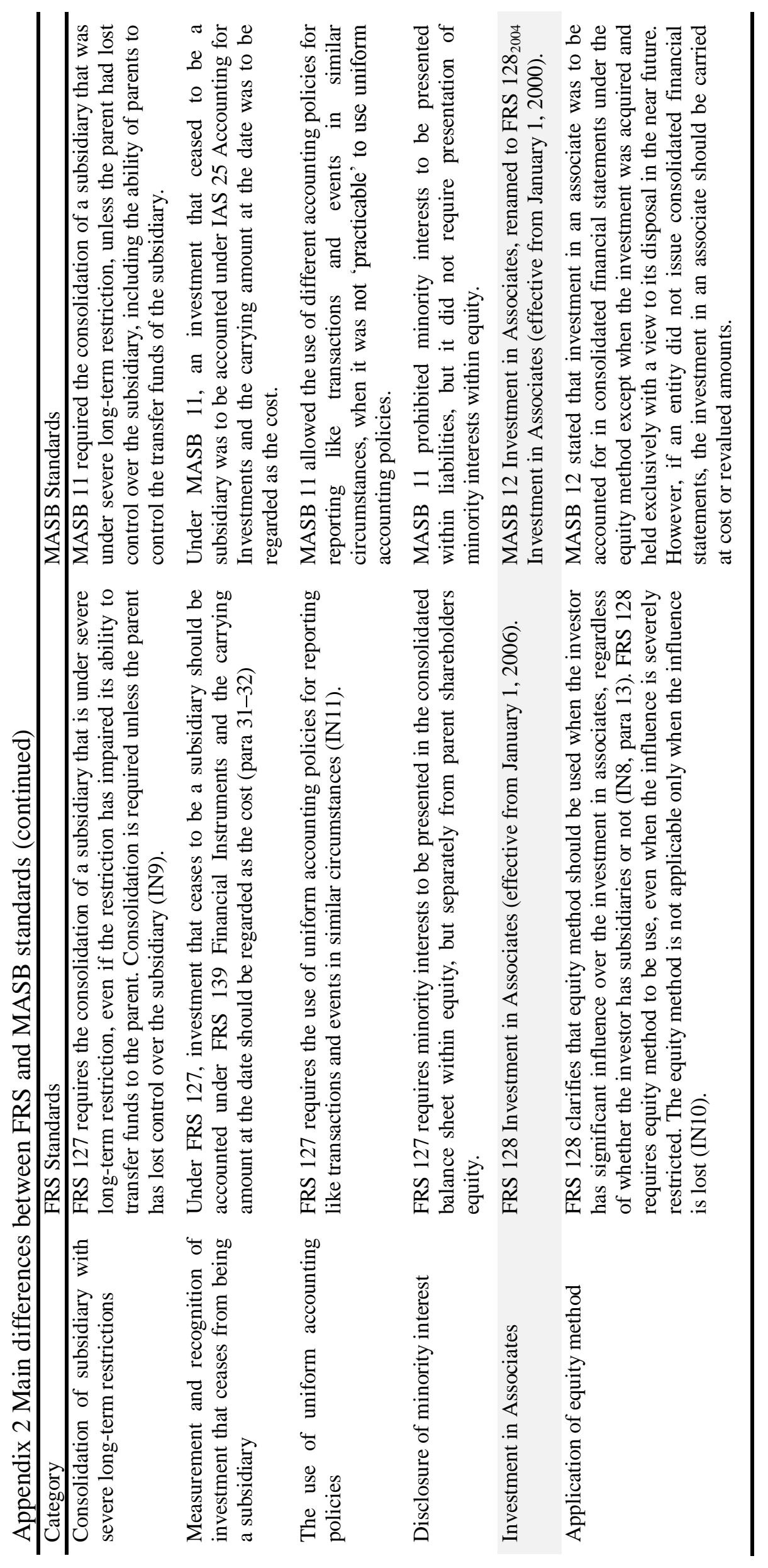

$\frac{0}{2}$ 


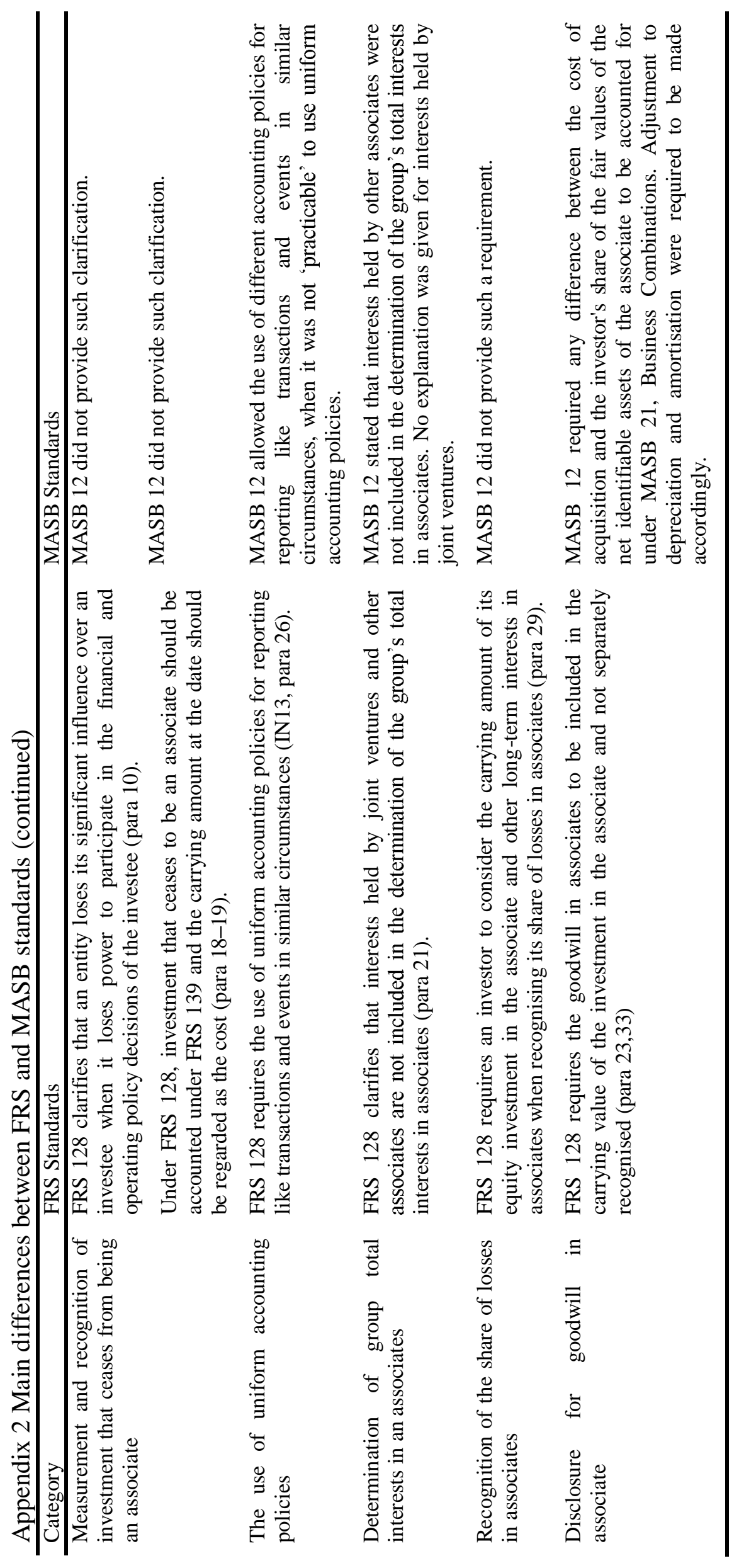

$\sqrt{2}$ 


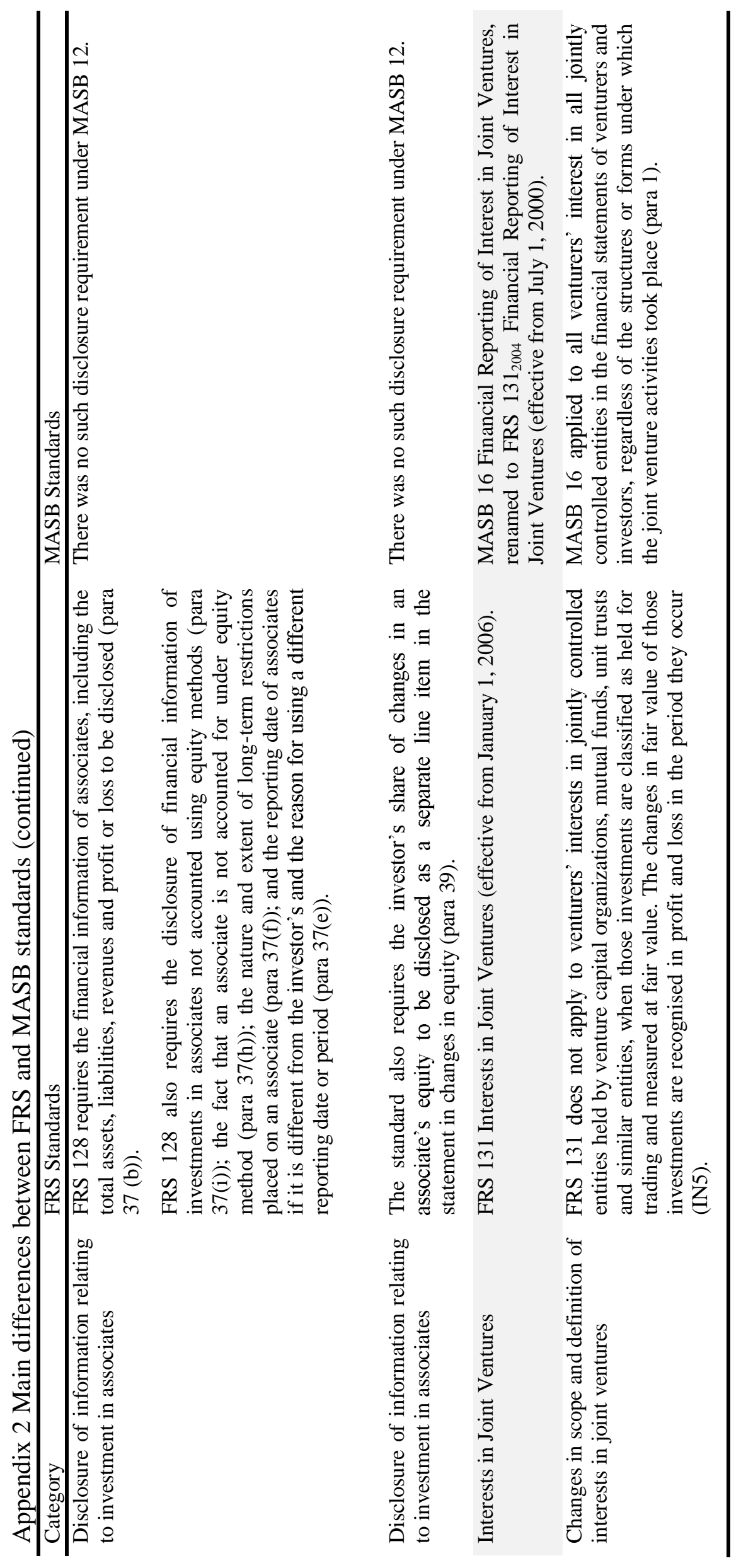

ลี 


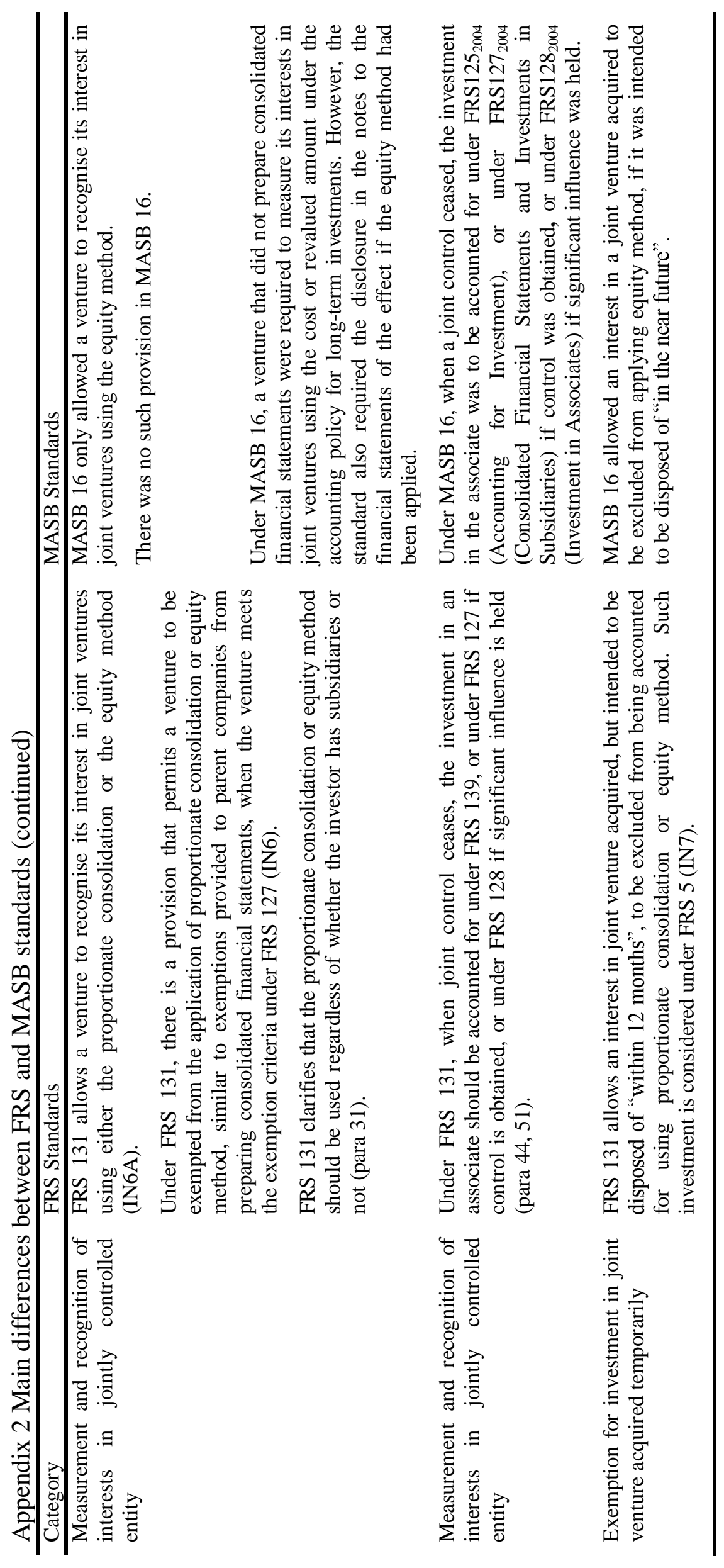

$\frac{m}{N}$ 


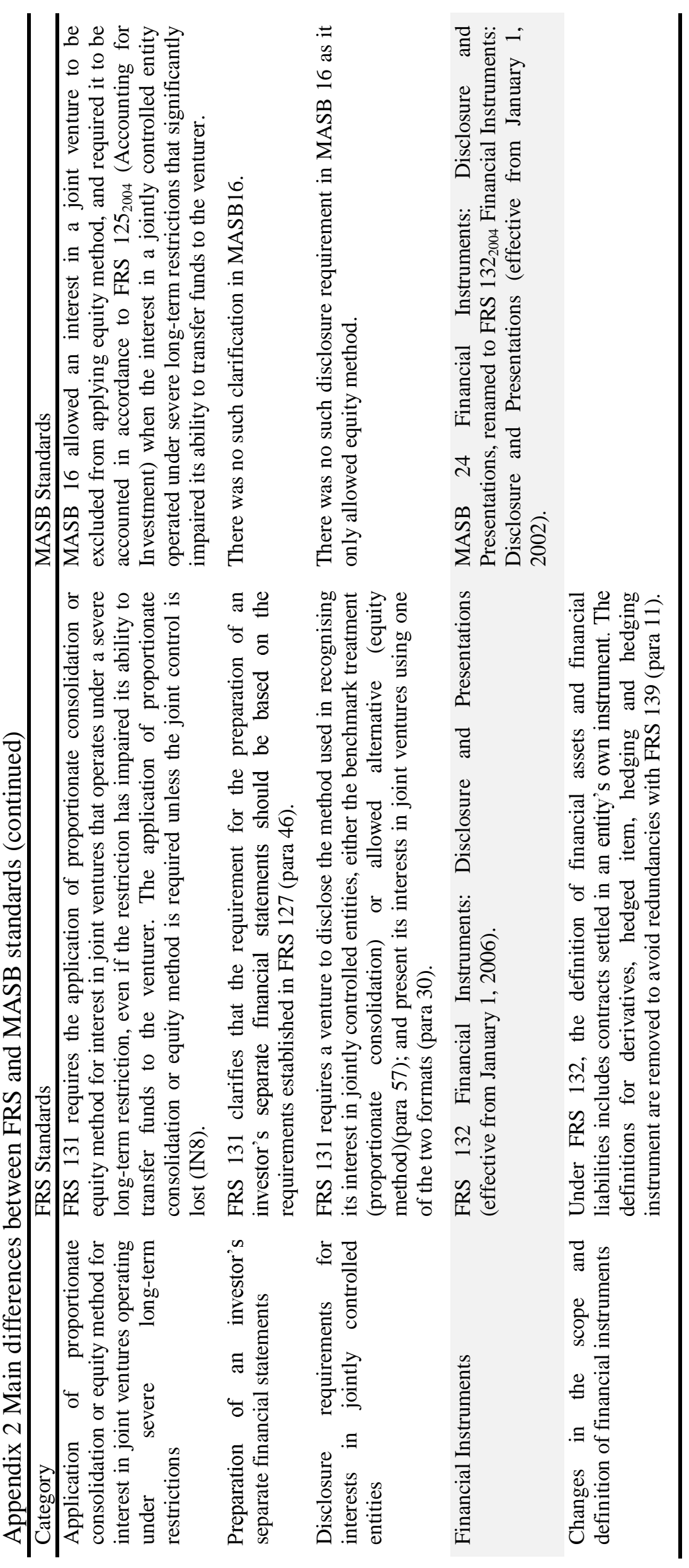

존 


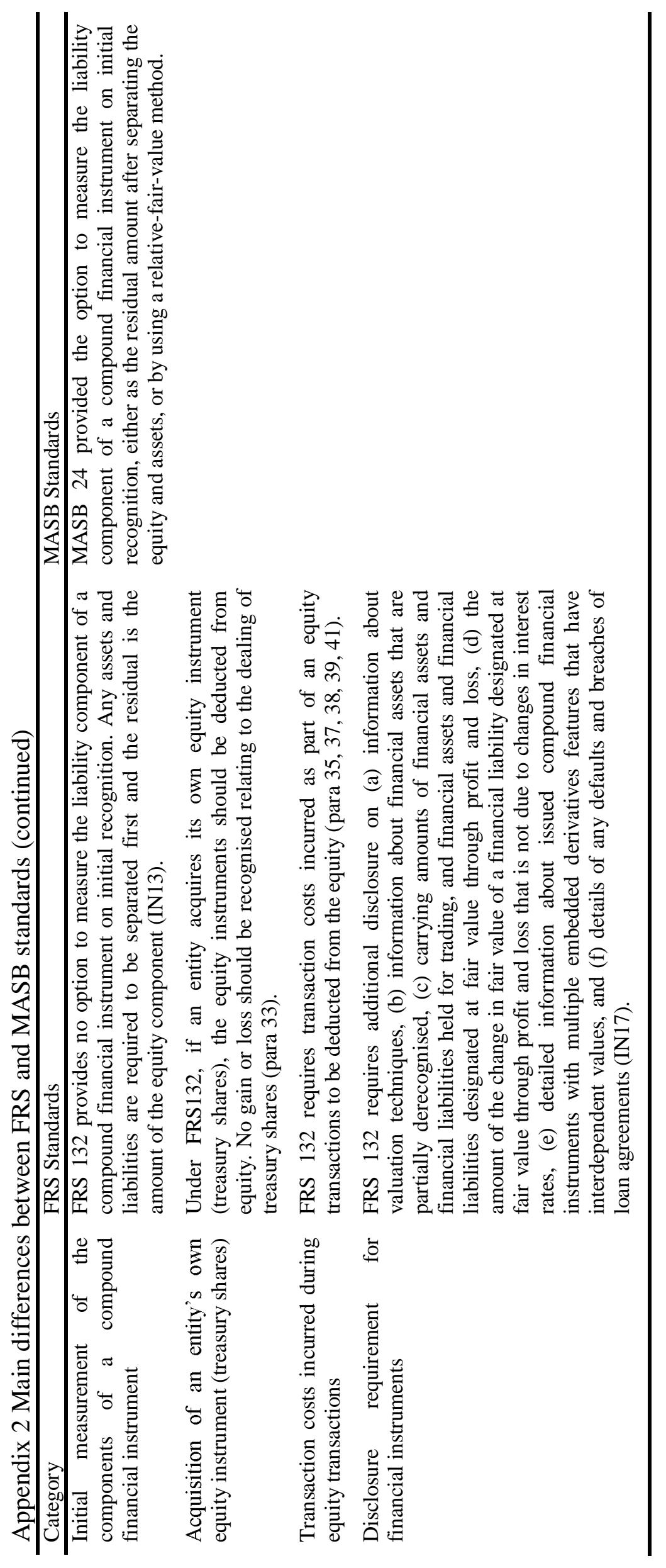




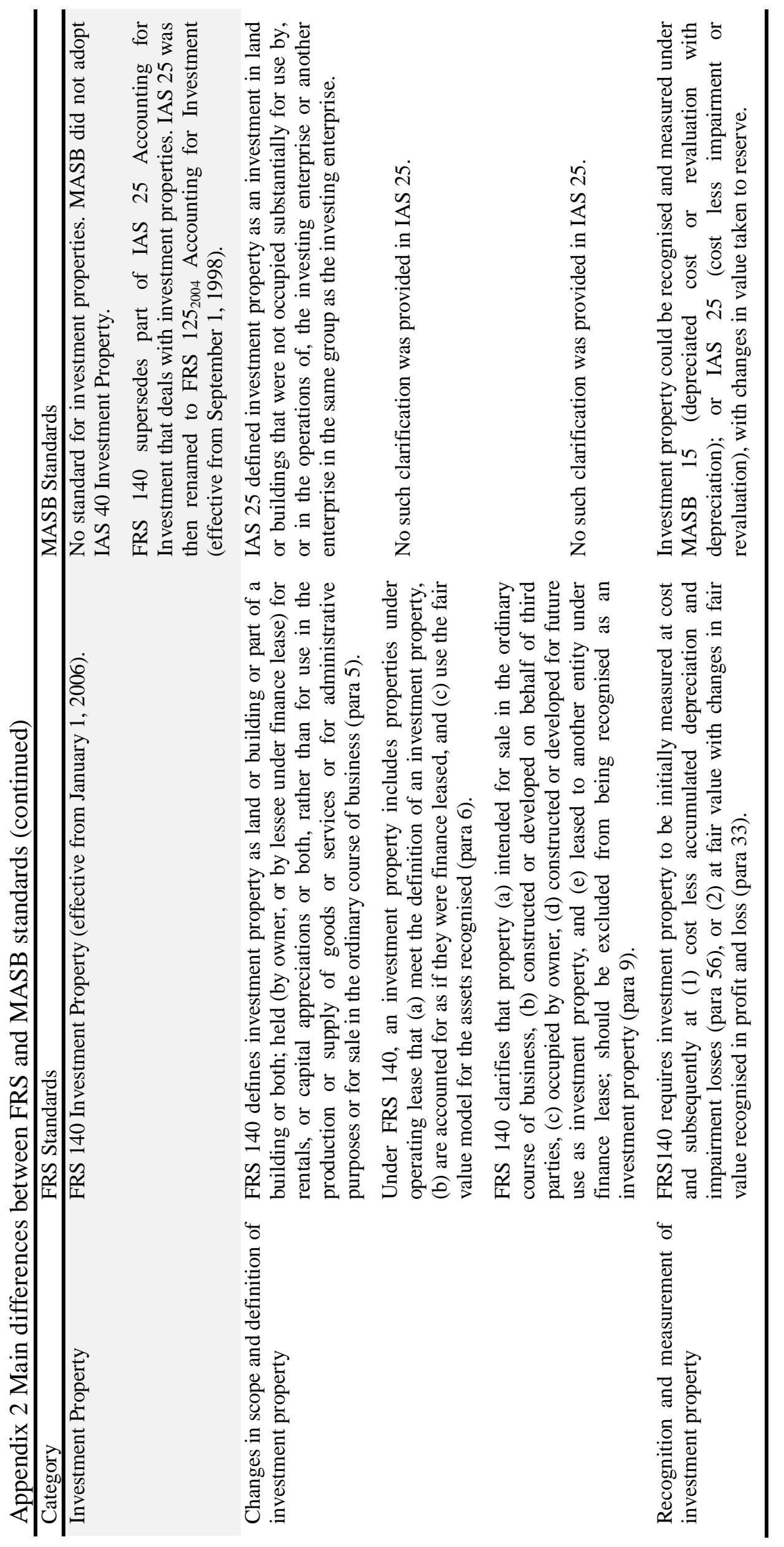

$\frac{0}{2}$ 


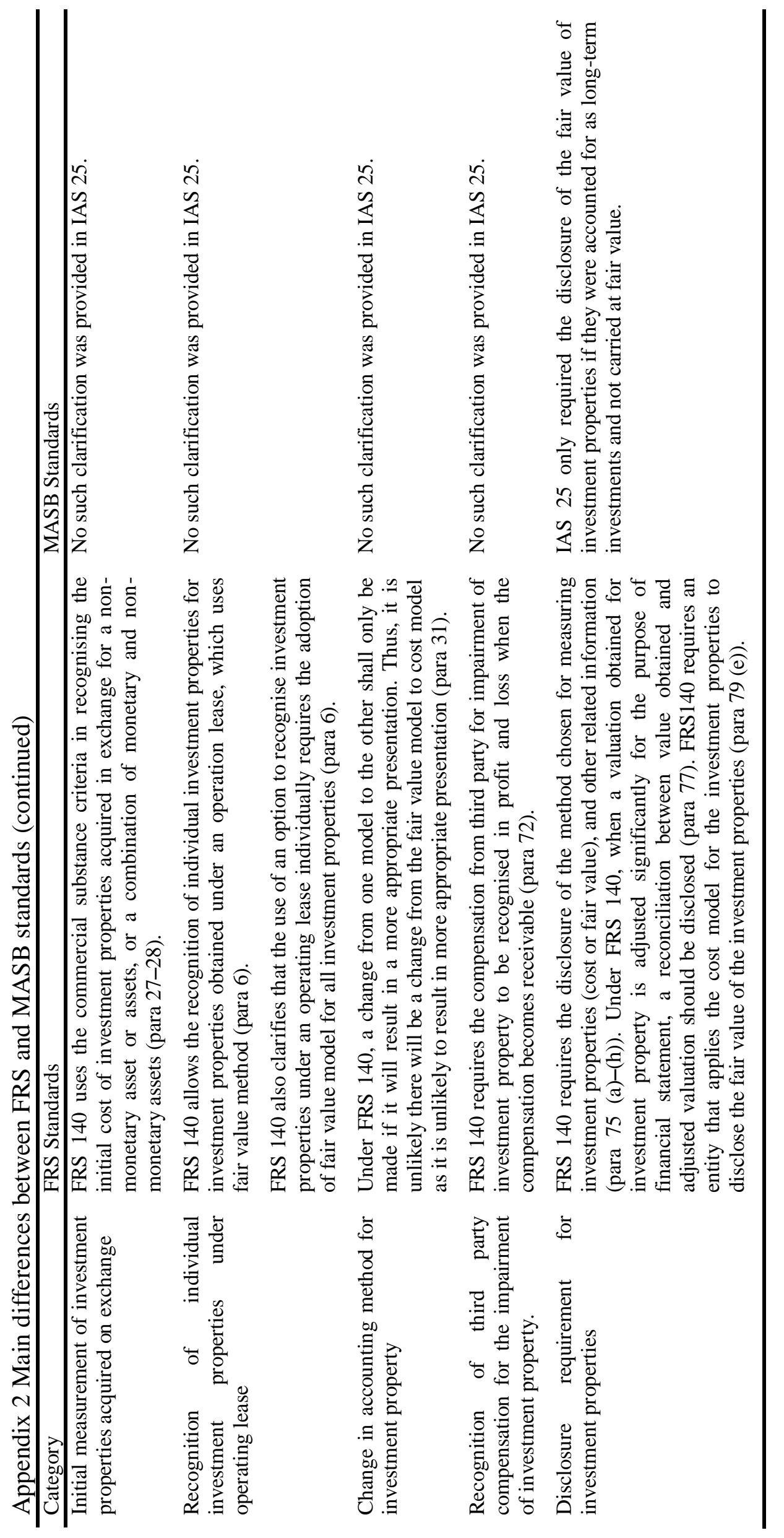

